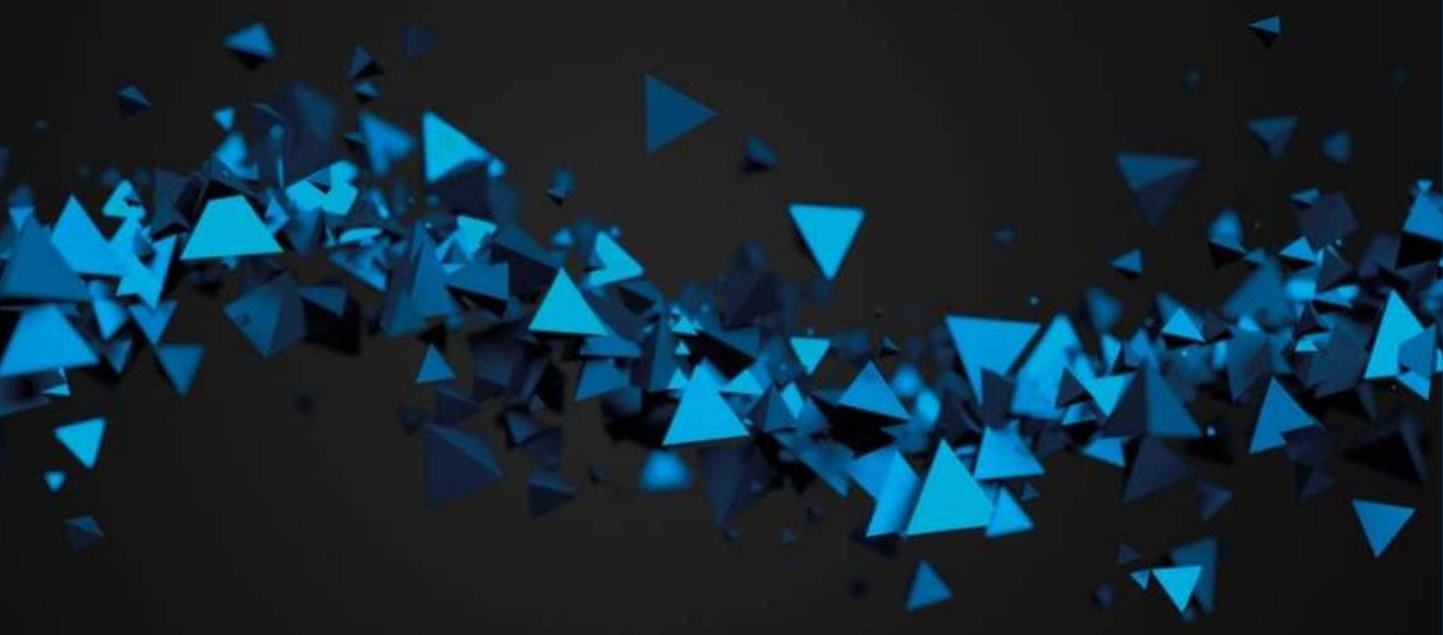

\title{
Coaching im digitalen Wandel
} Robert Wegener/Silvano Ackermann / Jeremias Amstutz/Silvia Deplazes / Hansjörg Künzli/Annamarie Ryter 


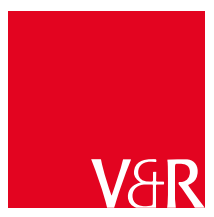


Robert Wegener/Silvano Ackermann/

Jeremias Amstutz/Silvia Deplazes /

Hansjörg Künzli/Annamarie Ryter (Hg.)

\section{Coaching im \\ digitalen Wandel}

Mit 7 Abbildungen und 4 Tabellen

Vandenhoeck \& Ruprecht 


\section{Publiziert mit Unterstützung des Schweizerischen Nationalfonds zur Förderung der wissenschaftlichen Forschung.}

Bibliografische Information der Deutschen Nationalbibliothek:

Die Deutsche Nationalbibliothek verzeichnet diese Publikation in der Deutschen Nationalbibliografie; detaillierte bibliografische Daten sind im Internet über https://dnb.de abrufbar.

(C) 2020, Vandenhoeck \& Ruprecht GmbH \& Co. KG, Theaterstraße 13, D-37073 Göttingen Das Werk und seine Teile sind urheberrechtlich geschützt.

Das Werk ist als Open-Access-Publikation im Sinne der Creative-Commons-Lizenz BY-NC-ND International 4.0 (»Namensnennung - Nicht kommerziell - Keine Bearbeitung «) unter dem DOI 10.13109/9783666407420 abzurufen. Um eine Kopie dieser Lizenz zu sehen, besuchen Sie https://creativecommons.org/licenses/by-nc-nd/4.0/.

Jede Verwertung in anderen als den durch diese Lizenz erlaubten Fällen bedarf der vorherigen schriftlichen Einwilligung des Verlages.

Umschlagabbildung: VAlex/Shutterstock.com

Satz: SchwabScantechnik, Göttingen

Vandenhoeck \& Ruprecht Verlage | www.vandenhoeck-ruprecht-verlage.com

SBN (Print): 978-3-525-40742-4

ISBN (OA): 978-3-666-40742-0 


\section{Inhalt}

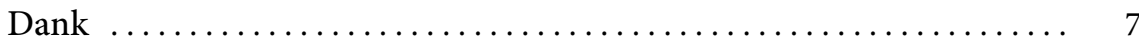

Einführung $\ldots \ldots \ldots \ldots \ldots \ldots \ldots \ldots \ldots \ldots \ldots \ldots \ldots \ldots \ldots \ldots \ldots \ldots \ldots \ldots, \quad 9$

Coaching im digitalen Wandel - Thesen und Perspektiven

Robert Wegener, Silvano Ackermann, Jeremias Amstutz,

Silvia Deplazes, Hansjörg Künzli und Annamarie Ryter

The challenges of coaching and mentoring in a digitally

connected world

An essay of an academic practitioner

David Clutterbuck

Kompetenzentwicklung für Online-Coaching $\ldots \ldots \ldots \ldots \ldots \ldots \ldots . \quad 30$

Silvia Deplazes und Hansjörg Künzli

Digital coaching: A conceptually distinct form of coaching? ........ 40

Stella Kanatouri

Chatbots as an instance of an artificial intelligence coach

A perspective on current realities and future possibilities

Nicola Strong and Nicky Terblanche

Designing a fit-for-purpose coaching model to create sustained individual change during career transitions $\ldots \ldots \ldots \ldots \ldots \ldots \ldots . \ldots 3$

Nicky Terblanche

Motto-Ziele im digitalen Wandel

Persönliche Metaphern als emotionale Ressource im Coaching

Thomas H. Dyllick

Through the eye of the camera: Experiences of

video-mediated coaching

Claudia Deniers 
Die Bedeutung der modernen Medien für die Professionalität von Coachingausbildungen

Harald Geißler

Digitalisierte Beratung zur effizienteren Selbstoptimierung

Kritische Anmerkungen zu digitalen Formaten arbeitsbezogener

Beratung aus einer Gouvernementalitätsperspektive

Volker Jörn Walpuski

Coaching von Wissenschaftler ${ }^{\star}$ innen im Kontext

der Digitalisierung

Coaching als Anker in entpersonalisierten Kommunikations-

und Konfliktprozessen

Monika Klinkhammer, Harry Enke und Neela Enke

Transformation Coaching und Generative Coaching

Neue Dimensionen der Coachingkultur von Organisationen

in der digitalen Arbeitswelt

Axel Klimek und Werner Stork

Organisation modernisieren und Führung entwickeln

Coaching für neue Führungskräfte im Kontext der Digitalisierung

Mathias Hofmann und Astrid Laudage

Digitaler Wandel - Möglichkeiten einer erfolgreichen Transformation

Elke Benning-Rohnke, Joachim Hasebrook und Marco Schärer

Die Autor*innen und Herausgeber*innen 


\section{Dank}

Der vorliegende Band »Coaching im digitalen Wandel« besteht aus Beiträgen zum 5. Internationalen Coachingkongress »Organisation, Digitalisierung und Design «, der am 12. und 13. Juni 2018 in Olten, Schweiz stattfand, organisiert durch die Hochschule für Soziale Arbeit der Fachhochschule Nordwestschweiz FHNW. Für die Bereitschaft, sich an den Anforderungen der Herausgebenden zu orientieren, danken wir den Autorinnen und Autoren herzlich. Wir danken ferner den folgenden Partnern für ihre Unterstützung, die den Kongress und diese Publikation erst ermöglicht hat:

\section{Förderorganisationen}

SGSA Schweizerische Gesellschaft für Soziale Arbeit

SNF Schweizerischer Nationalfond zur Förderung der wissenschaftlichen Forschung

\section{Hauptsponsoren}

BSO Berufsverband für Supervision, Organisationsberatung und Coaching

Coaching Institut Living Sense

CZO Coachingzentrum Olten

EMCC European Mentoring \& Coaching Council Schweiz

HR Today

IDC Institut de Coaching SA, Genève

ICF International Coach Federation Schweiz

OEVS Österreichische Vereinigung für Supervision

SBAP Schweizerischer Berufsververband für Angewandte Psychologie

SSCP Swiss Society for Coaching Psychology 


\section{Hochschulen}

Hochschule für Wirtschaft, Fachhochschule Nordwestschweiz

International Centre for Coaching and Mentoring Studies, Oxford Brookes University

Institute of Coaching, McLean Hospital, Harvard Medical School Affiliate

Pädagogische Hochschule, Fachhochschule Nordwestschweiz

\section{Unternehmen}

C for C - Coaching for Core

Change Coaching $\mathrm{GmbH}$

Christopher Rauen $\mathrm{GmbH}$

Freiburg Institut

Institut für Selbstmanagement und Motivation Zürich isb Wiesloch

Kurszentrum Aarau, Institut für Coaching und Lösungsorientierte Systemr therapie

Trigon Entwicklungsberatung

\section{Verbände}

DBVC Deutscher Bundesverband Coaching e. V.

DCV Deutscher Coaching Verband e. V.

DGSF Deutsche Gesellschaft für Systemische Therapie, Beratung und Familientherapie

DGSv Deutsche Gesellschaft für Supervision und Coaching e. V.

EASC European Association for Supervision and Coaching

EMCC European Mentoring and Coaching Council Deutschland

SCA Swiss Coaching Association

\section{Verlage und Medien}

Coaching Magazin

HR Today

Psychologie Heute/Beltz Verlagsgruppe

Springer

Ein herzliches Dankeschön geht auch an Ashley Slapp und Christoph Gassmann, die das Manuskript mit kritischem Blick, inhaltlichem Flair und großer Sorgfalt lektoriert und korrigiert haben. Nicht zuletzt danken wir dem Vandenhoeck \& Ruprecht Verlag, insbesondere Imke Heuer, für die kompetente Beratung. 


\section{Einführung}

\section{Coaching im digitalen Wandel - Thesen und Perspektiven}

Robert Wegener, Silvano Ackermann, Jeremias Amstutz, Silvia Deplazes, Hansjörg Künzli und Annamarie Ryter

Coaching hat sich in den letzten Jahren als personenorientiertes Beratungsformat im Kontext verschiedener Praxisfelder organisiert und etabliert (vgl. Wegener, Loebbert \& Fritze, 2016). Einzelpersonen, Teams und Organisationen nehmen zur professionellen Entwicklung zunehmend dieses Format in Anspruch. Nicht nur in den ursprünglichen Handlungsfeldern wie Sport oder Wirtschaft spielt Coaching mittlerweile eine wichtige Rolle, sondern auch im Kontext der Arbeitsintegration, der Wissenschaft und in vielen weiteren Praxisfeldern (a. a. O.). Das hat damit zu tun, dass Coaching in besonderer Weise die Aktivierung und Verbesserung von Selbststeuerung adressiert und sich damit wesentlich von herkömmlicher (Fach-)Beratung unterscheidet (Loebbert, 2016).

Der vorliegende Band, »Coaching im digitalen Wandel «, positioniert sich bewusst im Kontext der zunehmend digitalisierten und weiter sich digitalisierenden Arbeitswelt und der damit verbundenen (weiteren) Professionalisierung von Coaching. In diesem Zusammenhang stellen sich unter anderem die folgenden Fragen:

- Wie könnte sich die Digitalisierung auf den Bedarf nach Coaching auswirken?

- Wie verändert die Digitalisierung, insbesondere der Einsatz moderner Medien, das Beratungsformat und allenfalls auch seine Wirksamkeit?

- Wie positioniert sich Coaching angesichts gesellschaftlicher Veränderungen im Zuge der Digitalisierung als Profession?

\section{Digitalisierung und Bedarf nach Coaching}

Digitalisierung geht einher mit einer rasanten Beschleunigung von Prozessen. Was technologisch möglich wird, Kommunikation innert Sekunden über Kontinente hinweg, verändert das Kundenverhalten und die Erwartungen an Arbeitnehmerinnen. Die Märkte sind nicht mehr stabil, können disruptiven 
Veränderungen unterworfen sein oder ganz wegbrechen. Die Konkurrenz ist global, der Druck auf schnelle Veränderungen und Entwicklungen nimmt zu. Was im Bereich der Softwareentwicklung begonnen hat, prägt heute zukunftsgerichtete Organisationen in allen Branchen. Netzwerkstrukturen, agile und flexible Arbeitsformen und interdisziplinär auf Aufträge ausgerichtete Teamarbeit erweisen sich als Erfolg versprechend. Design Thinking oder Scrum haben herkömmliche, starre Projektmanagementmethoden abgelöst. Digital Leadership verzichtet auf traditionelle Hierarchieformen, weil diese sich als schwerfällig erwiesen haben und nicht rasch genug auf Kundenwünsche und technologische Veränderungen reagieren können (detaillierter dazu Creusen, Gall \& Hackl, 2017; Petry, 2016). Hoch qualifizierte Fachkräfte sind zudem in vielen Unternehmen knapp; wer Mitarbeitende an sein Unternehmen binden will, wird auf ihre Zufriedenheit im Job besonders achten. Anerkennung in Form von zusätzlichem Lohn ist längst nicht mehr für alle Arbeitnehmer*innen attraktiv. Verlangt wird heute eine sinnstiftende, selbstbestimmte Arbeitsweise (Creusen et al., 2017; Laloux, 2015).

Damit verändern sich auch die Anforderungen an Führungspersonen und an die meisten hoch qualifizierten Mitarbeitenden. In selbstorganisierten Netzwerken und Teams brauchen alle Beteiligten Flexibilität und Kreativität zur Lösung von komplexen Aufgaben. Für die effiziente Arbeit in interdisziplinären und interkulturellen Teams ist Kooperations- und Konfliktfähigkeit gefragt. Auch Mitarbeitende ohne Führungsfunktion müssen weitreichende Entscheidungen treffen und deren Folgen abschätzen können. Prozesswissen ist nicht mehr nur Sache von Führungspersonen, sondern wird von allen Teammitgliedern erwartet. Laloux (2015) berichtet von unterschiedlichsten Organisationen im Profit- und Non-Profit-Bereich, die Hierarchien abgeschafft und kleine dezentrale Teams mit hoher Entscheidungskompetenz gebildet haben. Sie konnten so nicht nur Kosten sparen, sondern auch effizient und passgenau anstehende Probleme lösen. Zudem hat sich die Zufriedenheit der Mitarbeitenden erhöht. Sie erleben ihre Arbeit als motivierend und sinnstiftend, die Zahl der Krankheitstage ist drastisch zurückgegangen. Zugleich stieg auch die Zufriedenheit von Kund ${ }^{*}$ innen. Kleine moderne Start-ups agieren heute meist von Anfang an in selbstorganisierten Netzwerken. Traditionelle, hierarchisch organisierte Unternehmen sind gefordert, überkommene Strukturen und Verhaltensweisen zu verändern. In diesen komplexen Prozessen können Einzel- und Teamcoachings sinnvoll unterstützen.

Entsprechend lautet eine erste These dieser Publikation: Coaching, das die Selbstorganisation von Menschen in komplexen Arbeitssituationen stärkt, Reflexion und Perspektivenwechsel ermöglicht und Emotionen einbezieht, ist ein attrak- 
tives Beratungsformat für Organisationen im digitalen Wandel. Um das professionelle Format der Beratung weiter zu etablieren, gilt es für Professionelle, sich gleichzeitig mit den anstehenden Herausforderungen der digitalen Transformation in Organisationen aktiv auseinanderzusetzen. Es braucht eine vertiefte Diskussion der Frage, welchen spezifischen Beitrag Coaching für digitale Führungskräfte und evolutionäre Organisationen leisten kann und soll.

\section{Digitalisierung des Beratungsformats und allenfalls veränderte Wirksamkeit}

Die Digitalisierung hat längst auch im Coaching Einzug gehalten. Es gibt bis heute kaum noch Coaches, die nicht ab und zu das Telefon oder computerbasierte Kommunikationsmedien einsetzen würden. Neben dem Face-to-FaceCoaching haben sich verschiedene Formen des Blended Coaching etabliert, bei dem zwischen den Sitzungen vor Ort gewisse Fragestellungen online bearbeitet und entsprechende Methoden eingesetzt werden. Plattformen mit digitalen Coachingtools wie Visualisierungsmöglichkeiten, Strukturhilfen bis hin zu systemischen Aufstellungen und Formaten der digitalen Prozessführung ergänzen das Angebot. Bachmann und Fietze (2018) gehen davon aus, dass Formen des Blended Coaching in Zukunft gegenüber dem reinen Face-to-Face-Coaching an Bedeutung gewinnen dürften. Festzuhalten ist, dass sie sich jetzt schon wachsender Beliebtheit erfreuen (Berninger-Schäfer, 2018; Ghods \& Boyce, 2013). Das ist kein Zufall, denn in einer globalisierten Arbeitswelt überbrückt Remote Coaching Distanzen, spart Reisezeiten und damit auch Kosten.

In der Literatur finden sich für diese neuen Coachingformen verschiedene Begriffe, die nicht immer trennscharf sind und bei denen oft erst aus dem Kontext klar wird, ob Face-to-Face-Formate noch vorkommen oder ob alle Interaktionen über Computer vermittelt sind. Gesprochen wird von Remote Coaching, Online-Coaching, medial vermitteltem Coaching, digitalisiertem Coaching.

Die meisten der hier publizierten Aufsätze fokussieren die Veränderung der Kommunikation zwischen Coach und Klient ${ }^{\star}$ in bzw. den veränderten Coachingprozess. Einen Überblick über spezifische Chancen und Anforderungen von unterschiedlichen Formen medial vermittelten Coachings geben BerningerSchäfer (2018) und Geißler (2017).

Während in den letzten Jahren ein signifikanter Anstieg an ergebnis- und speziell auch prozessorientierter Forschung zu herkömmlichem Coaching zu ver- 
zeichnen ist (vgl. Wegener, 2019; Wegener \& Ackermann, im Erscheinen), hinkt die Wissenschaft zu Online-Coaching der Entwicklung in der Praxis hinterher. Evidenz zu verschiedenen Aspekten von digital vermitteltem Coaching, wie zum Beispiel zu Verbreitung und Nutzung, verwendeten Formaten und Angeboten, zu Zielgruppen, Akzeptanz durch Coachees, Coaches und Organisationen, Wirkfaktoren und Wirkungen von digital vermitteltem Coaching, ist spärlich. Eine gute, aber bereits ein wenig in die Jahre gekommene Übersicht zu verschiedenen Aspekten von digital vermitteltem Coaching findet man bei Ghods und Boyce (2013). Dort wird allerdings neben einigen nicht publizierten Dissertationen nur gerade eine Wirksamkeitsstudie (Bowles \& Picano, 2006) besprochen. Ganz anders sieht es im verwandten Feld der digital gestützten Psychotherapie aus. Dort liegt bereits eine Vielzahl an Studien vor, welche die Wirksamkeit dieser neueren Angebote zeigen (vgl. für weitere Details den Beitrag von Deplazes und Künzli in diesem Band, S. 30). Hier ist ein Forschungsdesiderat auszumachen.

Entsprechend lautet unsere zweite These: Coaching als personenorientiertes Beratungsformat muss sich im Zuge der Digitalisierung selbst weiterentwickeln, aktualisieren und teils neu erfinden. Es braucht einen reflektierten und wissenschaftlich gestützten Einsatz moderner Medien, die Entwicklung entsprechender Konzepte und eine kritische Wirksamkeitsforschung.

\section{Positionierung der Profession}

Die Digitalisierung hat also das Coaching erreicht, aber lange noch nicht so durchdrungen wie andere Lebensbereiche. Wir sind gerade dabei zu erfahren, wie sich zwischenmenschliche Kommunikation in die virtuelle Welt verlagert. Welche Konsequenzen dies gesellschaftlich und für die einzelnen Individuen hat, ist noch kaum abzuschätzen. Als Professionelle gilt es, sich kritisch zu fragen, welche Rolle Coaching nicht nur in der Arbeitswelt, sondern auch gesamtgesellschaftlich spielt.

Anhand breiter Studien, vornehmlich aus den USA, hat Alter (2018) herausgearbeitet, wie die zunehmende Digitalisierung mit Verhaltenssüchten einhergeht. Über 40 Prozent der befragten Erwachsenen gaben an, ohne Smartphone nicht mehr leben zu können, eine wachsende Zahl von psychiatrischen Kliniken spezialisiert sich bereits auf den Entzug von Internetsüchtigen. Jugendliche sind hoch gestresst vom Zwang, auf Plattformen Likes zu erhalten, gepaart mit dem Gefühl von Einsamkeit und abnehmender Empathie- und Konzentrationsfähigkeit. Die Gleichzeitigkeit verschiedener virtueller Reize und ständiger Impulse, 
die mit der Digitalisierung einhergeht, führt so quasi zu einem gesellschaftlich antrainierten Aufmerksamkeitsdefizit. Es gibt Hinweise, dass Digitalisierung am Arbeitsplatz mit dem Grad emotionaler Erschöpfung zusammenhängt (Böhm, Bourovoi, Brzykcy, Kreissner \& Breier, 2016). Zu den Risiken der Digitalisierung zählt auch die Möglichkeit des Missbrauchs von Big Data. Die Skandale der letzten Jahre bei der Weitergabe von vertraulichen Informationen, zum Beispiel die politische Einflussnahme, die unter dem Namen des darin involvierten Datenanalyseunternehmens Cambridge Analytica bekannt wurde, sprechen für sich.

Insbesondere angesichts dieser problematischen Seite der Digitalisierung ist die Profession Coaching gefordert.

Fragen zur Position von Coaching in der reflexiven Moderne sind zwar nicht ganz neu (vgl. Fietze, 2016), stellen sich heute aber wesentlich pointierter. Wie können die Chancen der Digitalisierung unterstützt werden? Wo kann Coaching Einzelne, Teams und Organisationen ermächtigen, den digitalen Wandel menschlich zu gestalten im Hinblick auf evolutionäre Organisationen (Laloux, 2015)? Wie kann auf digitalen Plattformen den Coachees Vertraulichkeit zugesichert werden - angesichts der Tatsache, dass Daten auf dem Netz nie sicher sind? Gilt es, die Coachees vor allem in ihrer Selbstoptimierung zu unterstützen, ihre Leistung zu verbessern und damit die Beschleunigung durch die Digitalisierung weiter voranzutreiben? Oder könnte Coaching eher in Richtung einer Entschleunigung wirken: indem ein Raum persönlicher Begegnung, die Möglichkeit von Resonanz (Rosa, 2013) als tiefe Qualität menschlicher Beziehungen, geschaffen wird? Abseits der Digitalisierung bzw. als Erholung von ihr wird hier das Gewicht auf Empathie, Gemächlichkeit, Achtsamkeit im Hier und Jetzt gelegt. Kaum zufällig ist Mindful Leadership als Thema in Literatur und Führungsausbildungen im Aufwind. Neuere medizinische und neurologische Kenntnisse zu Stresserleben werden mit spirituellen Traditionen verknüpft, und es wird eine ganzheitliche Entwicklung fokussiert, die ja auch ein wichtiges Ziel von Coaching ist (Nardeshuber \& Nardeshuber, 2019; Marturano, 2015).

Carly Fiorina (2000) stellte einst lakonisch fest: »Wenn etwas digitalisiert werden kann, wird es auch digitalisiert werden. « Künstliche Intelligenz und Algorithmen könnten in Zukunft durchaus auch menschliche Coaches ersetzen. In Analogie zu anderen Bereichen wagen Bachmann und Fietze (2018) die These,

1 Bei diesem oft und gerne zitierten Satz handelt es sich um eine leicht verkürzte, sinngemäße Übersetzung aus dem Englischen. Im Original lautet der Satz wie folgt: »[...] e-services are any process, any application, any asset that can be digitized and delivered over the Web. Believe me, if it can be digitized, it will be." 
dass Face-to-Face-Coachings in nichtdigitalen Räumen quasi als Luxusangebot Bestand haben könnten.

Für professionelle Coaches gilt es in jedem Fall, sich mit digitalen Formen auseinanderzusetzen, sich Kompetenzen in der computergestützten Kommunikation anzueignen und zugleich kritisch gesellschaftliche Entwicklungen zu reflektieren. Digitale Kompetenzen als Voraussetzungen für Coaching könnten sich dabei als weitere Professionalisierungshürde erweisen.

Noch wenig diskutiert ist die Digitalisierung des Coachingmarkts und die Bedeutung für die Coachingverbände (zum Folgenden vgl. Bachmann \& Fietze, 2018). Wenn in Zukunft der Beitritt zu einer Plattform Voraussetzung für Sichtbarkeit und das Erreichen von Kund ${ }^{\star}$ innen ist, die Betreibenden aber zugleich mit teilweise intransparentem Vorgehen bzw. mit Zahlungen bessere Ratings produzieren, so hat das direkte Auswirkungen auf die Profession. Die Zukunft könnte so aussehen, dass die Geschäftslogik der Plattformbetreiber definiert, was Qualität ist, und nicht mehr die Kompetenzprofile von Verbänden. Bachmann und Fietze (2018) sprechen in diesem Zusammenhang von »Deprofessionalisierungstendenzen«. Hier gilt es aktiv zu werden.

Angesichts dieser vielschichtigen Entwicklungen lautet unsere dritte These: Coaching als professionelles Format der Beratung muss sich im Kontext der Digitalisierung noch viel deutlicher positionieren und sich zum Beispiel auch von dysfunktionalen Digitalisierungsentwicklungen distanzieren. Chancen und Risiken der Digitalisierung sind demnach in verschiedener Hinsicht zu reflektieren und sorgfältig begründet abzuwägen. Hier sind die Einzelnen und die Verbände gefordert.

Die in dieser Publikation veröffentlichten und nun gleich vorgestellten Artikel sollen zu den eben beschriebenen Herausforderungen und zur weiteren Professionalisierung von Coaching beitragen.

\section{Zum Inhalt der Publikation}

\section{Wissenschaftsorientierte Fachbeiträge}

David Clutterbuck beschreibt in seinem Essay die Möglichkeiten und Herausforderungen von Coaching und Mentoring in einer zunehmend digital vernetzten Welt. Dabei unterscheidet er technologische Entwicklungen, mittels deren Coaching zeit- und raumunabhängiger gestaltet werden kann, und technologische Fortschritte im Sinne der künstlichen Intelligenz, die mensch- 
liche Fähigkeiten ergänzen und erweitern können. Im Kern des Beitrags liegen zukunftsorientierte Ausführungen zur Frage, wie Mensch und künstliche Intelligenz gemeinsam Coaching verbessern können.

Silvia Deplazes und Hansjörg Künzli thematisieren in ihrem Beitrag die Eigenheiten von Online-Coaching als einer spezifischen Variante digital gestützten Coachings. Dazu beschreiben sie theoretische Grundlagen der computervermittelten Kommunikation (CVK) und spezifische Beratungskompetenzen, die für online tätige Coaches von besonderer Bedeutung sind. Beispiele dafür sind Medienkompetenzen - die Fähigkeit zur Medienkritik, Mediennutzung und Mediengestaltung. Deplazes und Künzli stellen kritisch fest, dass es bis dato und im Quervergleich zur Forschung zu online gestützter Psychotherapie kaum wissenschaftliche Nachweise für die Wirksamkeit von Online-Coaching gibt.

Stella Kanatouri skizziert in ihrem Beitrag die Grundlagen eines Konzepts für »digital Coaching«. Dazu verfolgt sie die Frage, was eigentlich passiert, wenn Face-to-Face-Coaching mit modernen Medien angereichert wird. Zur Beantwortung der Frage unternimmt Kanatouri auch einen interessanten Streifzug durch Kommunikationstheorien und Studienergebnisse, in denen zum Beispiel deutlich wird, dass eine tragfähige Arbeitsbeziehung - wie sie auch für digital vermitteltes Coaching grundlegend ist - mittels »schlanker « Medien wie zum Beispiel Telefon oder E-Mail - und damit nicht nur im Face-to-FaceCoaching - möglich ist. Weitere für ein Konzept von »Digital Coaching « wichtige Aspekte werden im späteren Verlauf des Beitrags erörtert.

Im Beitrag von Nicola Strong und Nicky Terblanche wird beschrieben, welchen Kriterien ein digitaler Coach, der auf künstlicher Intelligenz (KI) aufbaut, genügen müsste. Dabei thematisieren die beiden verschiedene Themenfelder, so etwa die Fähigkeit, menschliches Verhalten wahrnehmen zu können und über eine eigene Körpersprache und eine eigene Persönlichkeit zu verfügen. Zusätzlich zur Darstellung konkreter KI-Coach-Beispiele gehen die Autoren auf weitere Fragen ein, etwa die, wie menschlich ein solcher KI-Coach aussehen und über welche sprachlichen und zwischenmenschlichen Fähigkeiten er verfügen müsste. Zum Schluss stellen Strong und Terblanche ethische Fragen, deren Beantwortung für die weitere Entwicklung KI-gestützter Coaches als fundamental erscheint.

Nicky Terblanche skizziert in einem weiteren Artikel die wissenschaftliche Entwicklung seines »Transformative Transition Coaching«-(TTC-)Ansatzes für Mitarbeitende, die in Unternehmen umfassende Führungspositionen übernehmen. Dabei geht er zunächst auf empirische Befunde ein, die darauf hinweisen, dass viele solcher Karriereschritte oft nicht erfolgreich verlaufen und dass gerade Eins-zu-eins-Coaching einen wesentlichen Unterschied machen 
kann. Auf der Basis eines Verfahrens, das sich auf die Grounded Theory und Aktionsforschung stützt, beschreibt der Autor relevante konzeptionelle Komponenten dieses Coachingansatzes als Ergebnis seiner wissenschaftlichen Untersuchung, so beispielweise fünf Veränderungsphasen des mit dem Ansatz verbundenen Lernprozesses.

Haltung macht den Unterschied, so die zentrale These des Zürcher Ressourcen Modells ZRM. Thomas Dyllick zeigt in seinem Beitrag, wie Motto-Ziele - im Unterschied zu herkömmlichen SMART-Zielen - technologiegestützt als wichtige Komponenten tief greifender Veränderungsprozesse effizient gebildet werden können. Dabei werden Motto-Ziele als persönliche Metaphern beschrieben, die einer gewünschten inneren Haltung entsprechen. Im weiteren Verlauf des Beitrags zeigt der Autor, orientiert an eigenen wissenschaftlichen Studien, wie der Prozess der Bildung zielführender Motto-Ziele ohne externe Coaches und mithilfe eines Computers oder Tablets möglich ist und welche Effekte dies auf als negativ erlebte Verhaltensweisen haben kann.

Claudia Deniers gibt in ihrem Beitrag Einblick in eine Untersuchung zum Einfluss von videogestütztem Coaching. Auf der Grundlage von elf Interviews, geführt mit Coachees, die ein Skype-basiertes Coaching in Anspruch genommen haben, beschreibt die Autorin die verschiedenen Effekte dieses Coachingzugangs: Effekte (1) auf die Selbstwahrnehmung der Coachees, (2) auf die Wahrnehmung des Coaches, (3) auf die Beziehung mit den Coaches und (4) auf die durch den Skype-gestützten Coachingansatz gemachten Erfahrungen mit Raum.

Harald Geißler verfolgt in seinem Aufsatz die Frage, inwiefern der Einsatz von modernen Medien einen Beitrag an die Professionalität von Coachingausbildungen leisten kann. Dazu diskutiert er den Medienbegriff mit Blick auf eine für digital vermitteltes Coaching relevante Unterscheidung von Kommunikations- und Problemlösungsmedien. Weiter beschreibt er die Bedeutung von modernen Medien für Coachingausbildungen. Dabei nimmt Geißler Bezug auf eine ausschließlich digital durchgeführte Coachingausbildung und auf drei unterschiedliche Professionsvorstellungen: das klassische Professionsmodell, das Marktmodell und das Professionsmodell nach Ulrich Oevermann.

Volker Jörn Walpuski positioniert sich in seinem Beitrag bewusst kritisch und beschreibt verschiedene Aspekte, die trotz der Euphorie für die zunehmende Digitalisierung von Coaching und Beratung negativ ins Gewicht fallen. So etwa, dass sich kritisch-reflexive Beratung generell nicht beschleunigen lässt - dies aber durchaus ein Ziel der Digitalisierung ist - oder dass Körperlosigkeit im Kontext digitaler Coachingangebote - wie zum Beispiel Avatar-Welten - Entfremdungsprozesse « fördern können. Face-to-Face-Coaching erhält in diesem Kontext als »Premiumangebot« eine neue Rahmung. 


\section{Praxisorientierte Fachbeiträge}

Wissenschaftlerinnen schaffen es heute kaum mehr, sich als Koryphäen in ihrem Gebiet auf dem aktuellen Stand zu halten. Die Digitalisierung, so die zentrale These von Monika Klinkhammer, Harry Enke und Neela Enke, hat die Profession Wissenschaft beschleunigt. Die Reflexion der eigenen Identität und Verankerung von Wissenschaftler*innen hinkt dieser Beschleunigung hinterher, mit entsprechenden Folgen. Auf der Grundlage von zwei Falldarstellungen skizzieren die drei Autor ${ }^{\star}$ innen in ihrem Beitrag, wie Coaching im Kontext der zunehmenden Digitalisierung des Wissenschaftsbetriebs - und speziell Face-toFace-Coaching - einen relevanten Beitrag an die Bewältigung der hier erkennbaren neuen Herausforderungen leisten kann.

Im Kontext der Digitalisierung sind Organisationen massiven strukturellen Veränderungen ausgesetzt. Unternehmen wie Angestellte sind mit neuen Herausforderungen konfrontiert. Die Auseinandersetzung mit den neuen, oftmals komplexen Organisationsstrukturen fordern neue Herangehensweisen. Axel Klimek und Werner Stork erläutern, wie durch Coaching Agilität und Resilienz von Individuen und Organisationen systematisch gefördert werden sollen. Unter anderem plädieren sie für den Aufbau einer »Coachingkultur«, um die Herausforderungen im digitalen Zeitalter zu meistern.

Mathias Hofmann und Astrid Laudage stellen in ihrem Praxisbeitrag vor, wie die Digitalisierung einer Verwaltung Anlass für eine umfassende Personalentwicklung mit Unterstützung externer Coaches wird. Die Evaluation ergibt, dass herkömmliches Face-to-Face-Coaching mit ausgewählten instruktiven Teilen von den Beteiligten als hilfreich zur Bewältigung von Herausforderungen des digitalen Wandels eingeschätzt wird.

Elke Benning-Rohnke, Joachim Hasebrook und Marco Schärer beschreiben in ihrem praxisnahen Text, wie es Organisationen gelingen kann, der steigenden Komplexität und zunehmenden Digitalisierung durch den Einsatz von Einzelund Teamcoaching gerecht zu werden. Statt mehr Steuerung, Vorgabe und Kontrolle rufen die Autor ${ }^{*}$ innen überzeugend zu mehr Ermächtigung, Mitgestaltung und Verantwortung der Mitarbeitenden auf und rahmen damit zugleich eine sehr zeitgemäße und funktionale Vorstellung von Organisationsentwicklung.

Wir bedanken uns herzlich bei den Autor*innen, dass sie sich bereit erklärt haben, ihr wertvolles Wissen in dem vorliegenden Band zu teilen, und wünschen der Leserschaft viel Vergnügen bei dieser erhellenden Lektüre. 


\section{Literatur}

Alter, A. (2018). Unwiderstehlich. Der Aufstieg suchterzeugender Technologien und das Geschäft mit unserer Abhängigkeit. Berlin: Piper.

Bachmann, T., Fietze, B. (2018). Die Digitalisierung von Coaching - Gedanken aus der Perspektive teilnehmender Beobachtung. Organisationsberatung, Supervision, Coaching (OSC), 25 (3), 281-292.

Berninger-Schäfer, E. (2018). Online-Coaching. Wiesbaden: Springer.

Böhm, S. A., Bourovoi, K., Brzykcy, A., Kreissner, L. M., Breier, C. (2016). Auswirkungen der Digitalisierung auf die Gesundheit von Berufstätigen: Eine bevölkerungsrepräsentative Studie in der Bundesrepublik Deutschland. https://www.alexandria.unisg.ch/252056/ [6.5.2020].

Bowles, S. V., Picano, J. J. (2006). Dimensions of coaching related to productivity and quality of life. Consulting Psychology Journal: Practice and Research, 58 (4), 232-239.

Creusen, U., Gall, B., Hackl, O. (2017). Digital Leadership. Führung in Zeiten des digitalen Wandels. Wiesbaden: Springer.

Fietze, B. (2016). Coaching in der reflexiven Moderne. In R. Wegener, S. Deplazes, M. Hasenbein, H. Künzli, A. Ryter, B. Uebelhart (2016), Coaching als individuelle Antwort auf gesellschaftliche Entwicklungen (S. 36-44). Wiesbaden: Springer.

Fiorina, C. (2000). The Transformation Accelerates. Speech (october 17). CTEA Conference. Detroit, Michigan. www.hp.com/hpinfo/execteam/speeches/fiorina/ceo_ctea_00.html [1.5.2020].

Geißler, H. (2017). Moderne Medien im Coaching und in der Coachingausbildung. Wirtschaftspsychologie, 19 (2), 5-15.

Ghods, N., Boyce, C. (2013). Virtual Coaching and Mentoring. In J. Passmore, D. B. Peterson, T. Freire (Eds.), The Wiley-Blackwell Handbook of the Psychology of Coaching and Mentoring (pp. 501-523). Chichester: Wiley \& Sons.

Laloux, F. (2015). Reinventing Organizations. Ein Leitfaden zur Gestaltung sinnstiftender Zusammenarbeit in Institutionen. München: Vahlen.

Loebbert, M. (2016). Coaching Theorie (2., aktualisierte Auflage). Wiesbaden: Springer.

Marturano, J. (2015). Mindful Leadership. Ein Weg zu achtsamer Führungskompetenz. Freiburg/ Breisgau: arbor.

Nardeshuber, E., Nardeshuber, J. (2019). Mindful Leader. Wie wir die Führung unseres Lebens in die Hand nehmen und Gelassenheit zum Erfolg führt. München: Barth.

Petry, T. (Hrsg.) (2016). Digital Leadership: erfolgreiches Führen in Zeiten der Digital Economy. Freiburg/Breisgau: Haufe.

Rosa, H. (2013). Beschleunigung und Entfremdung. Entwurfeiner kritischen Theorie spätmoderner Zeitlichkeit. Berlin: Suhrkamp.

Wegener, R. (2019). Bedeutsame Momente im Coaching. Eine explorative Untersuchung zur Weiterentwicklung der Prozessforschung. Wiesbaden: Springer.

Wegener, R., Ackermann, S. (im Erscheinen). Von Wirkfaktoren zu bedeutsamen Momenten. Ergebnisse und Entwicklungen der Coaching-Prozessforschung. In C. Rauen (Hrsg.), Handbuch Coaching (4. Auflage). Göttingen: Hogrefe.

Wegener, R., Loebbert, M., Fritze, A. (Hrsg.) (2016). Coaching-Praxisfelder. Forschung und Praxis im Dialog (2., überarbeitete Auflage). Wiesbaden: Springer VS. 


\title{
The challenges of coaching and mentoring in a digitally connected world
}

\author{
An essay of an academic practitioner
}

David Clutterbuck

\begin{abstract}
Emerging technologies typically pose both challenges and opportunities. This paper explores the potential impact of artificial intelligence on coaching and mentoring. I provide first an overview of how electronic media have influenced coaching and mentoring to date, then review the current state of artificial intelligence technologies and how they may enhance coaching practice by humans and also how they may in some circumstances replace basic level coaching. Finally, I explore the exciting potential of coach-artificial intelligence partnerships and how to create these alliances. It appears from this analysis that the ability of coaches to incorporate artificial intelligence into their practice may depend at least in part to their stage of socio-emotional and cognitive maturity. However, there are also potential dangers and downsides of bringing artificial intelligence into the coachclient relationship.
\end{abstract}

It is a truism that every tool can be used for good or ill. It is also probably true that every idea can equally be used with positive or negative intent and/or impact. In this short essay, I focus on existing and emerging technologies, exploring how they can be used now and how they may be used in the future. I also look at the challenges posed by these current and future technologies.

The point of using technology is firstly that it makes a task or activity easier, or less costly in either effort or resource use, or both; and secondly that it enhances the activity, making it more accurate, or more effective, or gives it additional functionality.

We can divide technological advancement in coaching and mentoring into two, sometimes overlapping, categories: those relating to time and space and those relating to enhancing and supplementing human faculties. To the first of these belong the technologies of telecommunication, including e-mail, Skype 
and a host of meeting platforms. To the second belong the emerging capabilities of artificial intelligence.

\section{Time and space}

I find it hard to believe that less than 20 years ago, I was expressing great doubts about the viability of email based mentoring and coaching. Surely, the quality of interaction and conversation would be much poorer. With experience of using both synchronous and a-synchronous media and of studying the subject (Clutterbuck \& Hussain, 2009), I rapidly learned that both face-to-face and virtual coaching and mentoring could be highly effective. Each had its key pluses and minuses. Face-to-face meetings were rich in communication at multiple levels for example, rapport building, body language and intuition. But they are also prone to information overload. Coaches and mentors constantly have to select what to take notice of and which path they want to follow in the conversation. (Every time they ask a question, it directs the flow of conversation along a path they have chosen.) Much of the richness of conversation is, therefore, lost.

Email-based conversations, at the other extreme, are »thin « in the sense that they capture only the written word, sometimes supplemented by emojis. But the potential to analyse the content of the conversation, identifying hidden themes and undercurrents (revealed, for example, by recurrent use of particular words or phrases) is much greater than face-to-face. If a coach or mentor were to capture such detail, they could not possibly be fully present with the client. Moreover, it is possible with email to track back and compare evolving conversations over time.

Another point of comparison is thinking time. With face-to-face conversations, the dyad has to work at creating space to reflect. It is easier for a coachee or mentee to react immediately to a question, rather than ponder on it deeply. With asynchronous e-mail conversations, thinking time is built in - and this leads to deeper reflections by the client and more considered questions by the coach or mentor.

In-between face-to-face and asynchronous e-mail lies a spectrum of other media choices. Video connection and other forms of meeting room allow both parties to see each other, but the head and shoulders frame provides only facial and vocal clues to the client's emotional reactions. Bandwidth problems still cause irritating interruptions - often at critical points in the conversation. The old-fashioned non-visual telephone relies solely on the words spoken and the ability of the coach or mentor to intuit emotional and other clues. (One of the 
reasons for poor quality coaching in the US particularly is that inexperienced coaches lacking intuitive competence rely on telephone coaching.)

Among the growing area of virtual coaching is teacher training. The coach observes the teacher virtually in the classroom and is able to intervene with feedback (for example, by making a comment through an earpiece the teacher is wearing), making comments and suggestions in a running commentary (Rock, Zigmond, Gregg, \& Gable, 2011).

Fortunately, the wide choice of media now available enables dyads to employ a mix of media best suited to their needs. While we lack empirical data on how coaches and mentors manage multi-media relationships, it would appear that this is commonplace, if not the norm.

Among the existing and emerging challenges for time and space related technologies in coaching and mentoring are:

- Confidentiality. Many mentoring programmes within corporations encourage (or even require) participants to use designated platforms. Even if these are secure, they may be monitored by parties outside the mentoring dyads.

- Data overload. The problem of over-rich communication highlighted in physically face-to-face conversations is now emerging into virtual coaching and mentoring. As meeting platforms offer more and more functionality, such as document sharing, these enhancements can become distractions, leading conversations to become derailed and less purposeful.

- Shallow conversations. There is increasing confusion between genuine coaching or mentoring and FKT (Fast Knowledge Transfer), which links employees with a subject matter expert, for a specific and immediate transfer of knowledge. While these interactions may be valuable, they are transactions, not relationships, there is no continuous learning and no substantial way to connect the conversation to the learner's wider goals and »becoming «.

These challenges are not likely to diminish soon.

What does the future hold in this context? As global bandwidth problems become resolved, we can expect distance coaching and mentoring to be enriched with holographic projection. This will allow coach and client to see each other as if they were in the same room and, at least in theory, result in more natural conversations, with the ability to observe body language. We do not yet know how well intuition will work in this environment. A challenge will be achieving sufficient consistency to make the projected images real. Other options we can predict will be for participants to project not themselves, but an idealised avatar of themselves. 
An extension of this technology will be the ability to bring a whole team into a virtual room for team coaching, in a meld of communication technology and virtual reality. Some of the challenges here are still very basic. For example, wearing a heavy VR headset for long periods is tough and will remain so until they weigh roughly the same as a normal pair of audio headphones.

\section{Enhancing and supplementing human capabilities: Artificial intelligence in coaching and mentoring}

The roots of the algorithm as coach, or »intelligent coaching systems « lie in education, rather than in the wider field of coaching. They are described as »systems that slook over the shoulder of a student or user and interpret his/her performance of a cognitive task " (Breuker, 1998). At that stage, there is no indication of a conversation. Yet as I write, IBM has exhibited an AI capable of holding a debate. It is able to call upon a library of 10 billion sentences to respond to the arguments of its human debating rival. (The human won, but this is only round one!)

Other continuing experiments are building the capacity of algorithms to undertake therapeutic conversations, with the AI proving itself more accurate in diagnosis and marginally better than human therapists at appearing non-judgmental. The University of Southern California Institute for Creative Technologies' AI therapist has been designed to work with victims of post-traumatic stress disorder (Gratch, 2014). Ellie, the avatar therapist is designed to be humanlike, but clearly not a real person. She listens to clients and observes their facial expressions as they talk, analyses their responses and eases the conversation with nods and other signs of empathy. Laboratory tests show that clients open up more to the avatar than to real human therapists.

An AI has several significant advantages and disadvantages compared with a human therapist. Among the advantages are that it:

- registers micro-expressions that are usually too fleeting for a human to notice;

- more accurately observes other minute physical signs of stress;

- continues the conversation while analysing for patterns;

- holds an accurate record of previous sessions;

- does not have to deal with interference from "parallel processing « - where the coaches' own »stuff» intrudes.

A consistent factor behind these and other success stories is an immense investment of time, expertise and financial resources. When we compare this with the worlds of coaching and mentoring, the existing resources are at a much more 
basic level. Coachbots - algorithms that attempt to emulate the questioning approach of coaches are still very clunky, easily flummoxed and unlikely to be taken for a human. The investment to take them to that point would be enormous, requiring at the least a library of tens of thousands of coaching or mentoring conversations. Even with such a resource to draw upon, the challenge remains in determining what "good « looks like. If the AI »learns « from analysing thousands of poor or mediocre conversations, that is what it will emulate.

What an AI lacks includes the ability to draw on wider life experience, the associated skill of intuition and the ability to connect at the level of shared values, which underlies the creation of a professional friendship. A big question about the last of these is the extent to which clients want to build a professional friendship with a therapist or coach. Sometimes it can be easier (as the USC researchers have found) to disclose in a neutral environment - in a human to human relationship, there is always at least a residual discomfort arising from the fear of being judged. It is also unclear whether the AI performs well at all the functions of a trauma therapist or just at the diagnostic functions.

\section{Who is under threat?}

So, what is to stop Ellie's near-future cousins replacing coaches? The answer, I suspect, lies in the purpose of coaching and in the coaches' relative maturity. In terms of coaching purpose, a well-accepted framework defines four types of intervention, of increasing complexity and capability required by the coach: skills, performance, behaviour change and transformational. Both skills and performance coaching function primarily through the application (conscious or unconscious) of a relatively small number of algorithms. (The much-overused »on a scale of 0 to 10 « process is one example of such an algorithm.) As long as there are frequently repeated patterns, seen in multiple situations and clients, an AI can learn to do these at least as well as a human. The USC researchers have already, for example, developed an AI for the US military that can coach soldiers to negotiate with an Afghan war criminal - a skill that requires, among other things, a high level of cultural sensitivity (Gratch, 2014).

So, skills and performance coaching are most at risk. Behavioural and transformational coaching are less at risk, because the core of the process is the internal reflection that clients undertake, much of it outside the formal coaching sessions. The personal experience and wisdom of the coach (or mentor) is more relevant, as is the art of helping someone connect with their values, find the metaphors that release their dreams, develop intrinsic motivation or let go. 
In terms of coach maturity, we define four levels (Clutterbuck, 2010). Modelbased coaches have one or two key models to draw upon that provide the boundary to their practice. Their minimal toolkit means that they do coaching to the client. Process-based coaches have a wider portfolio of approaches, giving them the flexibility to engage in coaching with the client. Philosophy-based coaches have, after much deep reflection on their practice, integrated a coaching mindset with their identity, so we describe them as moving from doing coaching to being a coach. Systemic eclectic coaches move beyond this to a deeper understanding of the client within their context. We describe them as "holding the client, while the client has the conversation that they need to have with themselves".

It follows, therefore, that any coaching practice driven by a single or small number of models or processes is under threat. The doing of coaching can be replicated by an AI with relative ease. The being of coaching requires presence, intuition and immense compassion - a deeper emotion than is yet possible with an AI. And at the systemic eclectic level, algorithms are replaced by an instinctive dance, in which the coach says and does just enough to permit the client to find their own insights. There are patterns, but they are sufficiently original and variable to be beyond an AI's programming or ability to learn - yet.

Another differentiating factor is the concept of wisdom. As I define it, wisdom is the product of reflection on experience. An AI cannot experience, in the human sense of the term, and it cannot reflect. We can define three types of wisdom:

- skinny wisdom - expertise in a specific, bounded domain;

- broad wisdom - reflection on life experience (personal and vicarious);

- meta-wisdom - bringing together multiple, shifting perspectives.

An AI has the potential to engage in skinny wisdom, but there is no way (as yet) that we can envisage it having broad wisdom or meta-wisdom. Hence, mentoring - or at least the higher functions of mentoring - is likely to be immune to an $\mathrm{AI}$ takeover.

\section{Implications for coaching and coaches}

As with any major technological change, there are winners and losers. The losers will be the basic mindset coaches, unless they up their game and develop greater maturity in their practice. A rough estimate from observation of accredited coaches in coach assessment centres is that at least three out of five are stuck 
in the models or process levels. Add in unaccredited coaches and the size of the problem grows substantially.

The good news here is that the upcoming competition from AIs can be a great stimulus for professional development. The various professional bodies - particularly those in the Global Coaching and Mentoring Alliance - have a major role to play in supporting this transition, which is well in line with their joint and several objectives to raise professional standards. However, the flipside is that the emphasis on membership, which has in some cases focused on numbers (a sensible strategy when they can do so much more with critical mass), has to shift towards a focus on quality. Managing that balance will be a challenge!

Coach and mentor training organisations will also face a challenge. Those, whose focus has been ushering new coaches into coaching may either have to seek new markets or shift towards helping competent coaches reach higher levels of maturity. Many providers are manifestly a long way from meeting this challenge. Therefore, a growing role for professional bodies is likely to be raising the standard of coach trainers.

Supervision will also provide a differentiator from Ellie and her like. No one has (yet, to my knowledge) come up with a practical way to provide supervision for an AI, although it is possible to envisage an AI supervisor working with AI coaches (Lewis \& Clutterbuck, 2019).

As coaches, we can either bury our heads in the sand and hope AIs like Ellie and they will rapidly become more and more sophisticated - will go away. Or we can embrace the changes and start to plan how we will work alongside these avatars, shaping how they interact with clients and directing clients towards AIs for the tasks AIs are good at, while we concentrate on the more interesting and challenging coaching roles. I can, for example, see great potential in partnering with an AI in team coaching, where the AI can monitor the emotional dynamics of the team, informing me when a collective shift (positive or negative) is emerging. If Ellie and I cannot be friends, we can at least be allies!

If coaches are to benefit from the rise of AI, then they will need to embrace the new technology and integrate it in their practice. But what does that mean? The coach-AI partnership fulfils several functions:

- It provides real-time information about what is going on in the conversation, in the client and in the coach

- It allows instant access to other sources of relevant and potentially relevant information - for example, if the coach refers to a model or concept, the AI can retrieve a diagram and plain language explanation

- The AI can suggest questions and lines of enquiry (meaning that you as the coach have to spend less time thinking about what you are going to ask next) 
- You can check your intuitions for confirming or disconfirming evidence

- It creates opportunities for in-depth review of each coaching session, from the perspective of alternative approaches (for example, "You chose not to follow this clue, but how might the conversation have gone if you had? «) or better wording of questions. Of course, this is a learning process for both the coach and the AI.

\section{Making the coach-Al partnership work}

The key to successful partnerships will lie in questions such as the following:

- What am I not noticing? For example:

- The client avoids questions that address a particular area

- The micropauses, skin temperature changes, posture shifts and so on that indicate discomfort or other emotions: for example, an AI can learn to recognise the physical patterns that indicate when a client is lying to themselves

- How I am reacting to the client?

- What patterns are emerging? For example:

- Linguistic: for example, repeated words or phrases that appear to have a particular meaning or emotive undertone

- Narrative: for example, a tendency to self-sabotage or a set of limiting assumptions in the client about themselves or others

- Conversational: for example, is it going round in large circles? (The structure of conversation is usually too complex for humans to follow in the moment.) What can I, as a coach, learn from the patterns of this conversation that will improve my practice?

- What other bodies of knowledge might be relevant? For example:

- If I am feeling manipulated by the client, what are the signs of sociopathy that I might look out for? (And the AI can, of course, compare the conversation with those signs.)

- What do we know generally about people in the client's situation?

- What strategic planning models might be helpful here?

- What is too complex for me to analyse? For example, where the client is faced with multiple, complicated choices, you will be able to ask the AI to turn these into a decision tree, which you and the client can work through together.

- How can I test my intuition? The AI can either provide data relevant to the client in front of you, or a general overview of similar situations. 


\section{Some Al-coach scenarios}

\section{Visual enhancement}

The AI listens and draws images that relate to the narrative. It may link to a virtual world like Pro-Real to support the coach and the client in the conversation. The client's response provokes changes and the AI learns and adapts. When the client says, »I feel boxed in « for example, the AI may present a menu of images, which prompt the client to be more specific. Essentially, it is providing visual prompts for the client and the coach to follow.

The perceptive coach will note the difference between the images they were drawn to and those that the client responds to. This helps the coach detach more thoroughly from their own associations and assumptions - working with the client's world, not their own.

\section{Menu of resources}

There are so many tools, techniques and models available that it is impossible to have more than a small selection at our fingertips. In its dedicated chatroom, the AI highlights and constantly updates a menu of conceptual models, diagnostic questionnaires and other potentially relevant materials.

\section{Nuances of meaning}

Especially when people come from different linguistic and cultural backgrounds, the meaning they attach to words and phrases may be very different. It is easy to miss the significance of the other person's language. Armed with an analysis of hundreds of conversations from each of the cultures, the AI points out potential gaps in understanding.

\section{Coach supervision}

Both the coach and the supervisor bring their own AIs to the supervision session. As they dissect a case that the coach has brought for discussion:

- The coach turns to their AI to check what was actually said and what actually happened (as opposed to their rationalised memory of the conversation)

- The supervisor refers to their AI for theoretical constructs that may be helpful; and for parallels in cases brought to them by other coaches, or previously by the same coach 
- The two AIs communicate with each other, adapting the alerts and suggestions they offer to the coach and supervisor

\section{Enhanced reflection}

It is often not possible to reflect upon and learn from a coaching or mentoring session immediately after the event, when the memory is still the freshest. We can currently use an algorithm to remind us what to think about. In future, however, we will be able to programme an AI to look for patterns of language, conversational structure, meaning-laden words and phrases and other data that will help us achieve deeper and more meaningful reflection.

\section{The dangers of an Al-coach partnership}

Three main dangers stand out, though there may be many more that emerge with practice.

The first is that coach and AI may become such a strong partnership that the client is left out and feels both under scrutiny and manipulated. It will be essential, therefore, to develop a three-way partnership in which the client is also able to access the AI. The process of pausing and reviewing during coaching conversations will become even more important than at present, as both coach and client take the opportunity to review not just the conversation as they have experienced it, but also to request observations from the AI. As yet, we have no protocols for this situation, but there will need to be an understanding of whether it is most beneficial to the client to have constant data feed from the $\mathrm{AI}$, or periodic-pause interactions with the $\mathrm{AI}$, or a mixture of the two.

Another related danger is that the coach (or the client, if they are also AI-enabled) becomes distracted by the flow of information that the quality of their listening and attentiveness suffers.

Thirdly, humans instinctively respond to complexity-in-the-moment by focussing on the process. The journey towards coach maturity is one that starts with models and processes and gradually lets go of them as we become more confident in letting the client and the conversation follow their own path. If we become overwhelmed with information, we may revert to mechanistic, plodding conversations. If that happens, it is we, as coaches or mentors, who have become the robots! 


\section{A research agenda}

The paucity of research in the area of coach-AI partnerships provides many opportunities for research. Amongst themes that could usefully be explored are:

- To what extent are existing models of learning dialogue and coaching conversations applicable to the greater information content of AI-assisted coaching?

- What will an effective coach-AI partnership look like? (What implications does this have for coach education and accreditation?)

- What would a »Turing test« for an AI coach consist of?

\section{References}

Breuker, J. (1998). What are intelligent coaching systems and why are they inevitable? In Proceedings of Artificial Intelligence in Educational Software (pp. 11-16). London: IEE.

Clutterbuck, D. (2010). Coaching reflection: the liberated coach. Coaching: An International Journal of Theory, Research and Practice, 3 (1), 73-81. DOI: 10.1080/17521880903102308

Clutterbuck, D., Hussain, Z. (2009). Virtual Coach, Virtual Mentor. Charlotte, NC: Information Age Publishing.

Gratch, J. (2014). Virtual humans for interpersonal processes and skills. AI Matters, 1 (2), 24-25. Lewis, L., Clutterbuck, D. (2019). Co-evolution: exploring synergies between Artificial Intelligence (AI) and the supervisor. In J. Birch, P. Welch (Eds.), Coaching Supervision: advancing practice, changing landscapes. Abingdon, Oxon: Routledge.

Rock, M. L., Zigmond, N. P., Gregg, M., Gable, R. A. (2011), The Power of Virtual Coaching. Educational Leadership, 69 (2), 42-48. 


\title{
Kompetenzentwicklung für Online-Coaching
}

\author{
Silvia Deplazes und Hansjörg Künzli
}

\begin{abstract}
Online-Coaching ist am Markt angekommen. Es gibt kaum mehr Coaches, die nicht ab und zu Telefon, Mail, Chat, Videotelefonie oder eine Plattform mit mehreren Kommunikationskanälen nutzen. Was Theorieentwicklung und Wirkungsforschung angeht, bestehen freilich, anders als für das angrenzende Gebiet der Psychotherapie, noch beträchtliche Defizite. Auch die Frage der Kompetenzen, die im Online-Coaching vorausgesetzt sind, wird derzeit noch stiefmütterlich behandelt. Auf den ersten Blick entsteht der Eindruck, dass die Kompetenzen, die für die Präsenzberatung erworben wurden, sich ohne Verluste und Einschränkungen auf den Online-Bereich übertragen lassen. Im Beitrag wird gezeigt, dass Beratungskompetenz, die man für die Präsenzberatung erworben hat, zwar unverzichtbar ist, aber Online-Coaching je nach genutztem Kanal, auch zusätzliche Kompetenzen erfordern: zum einen technische Kompetenzen und Kenntnisse, zum Beispiel zu Datenschutz und Datensicherheit; zum andern geht es darum, sich gezielt Medienkompetenzen anzueignen.
\end{abstract}

Online-Coaching ist ein rasant sich entwickelndes Praxisfeld. Wer sich einen Überblick über aktuelle Entwicklungen verschaffen will, findet sich in einem undurchdringlichen Dickicht wieder: Das Spektrum reicht von Apps, die ungeleitete Selbsthilfe anbieten, bis hin zu Face-to-Face-Coachings, in denen zwischen den Sitzungen Mailkontakt zwischen Coachee und Coach besteht. Um das Feld ein wenig einzuengen, orientieren wir uns in unserem Beitrag an der folgenden Ad-hoc-Definition: Unter »Online-Coaching « fassen wir alle Formen von Coachings, die vollständig oder teilweise über Medien wie das Internet und/oder das Telefon abgewickelt werden. Online-Coaching in diesem Sinne unterscheidet sich von Präsenzberatung im Wesentlichen darin, dass Coaches und Coachees während der Interaktion nicht im gleichen Raum anwesend sind, sondern über Internet oder Telefon kommunizieren. 
Sowohl die Theorieentwicklung als auch der Stand der Forschung zu OnlineCoaching hinken den Entwicklungen in der Online-Psychotherapie deutlich hinterher. Um vom Wissen in der Online-Psychotherapie zu profitieren, wird im Folgenden immer wieder auf dieses angrenzende Feld verwiesen.

\section{Online-Coaching ist eine Realität}

Eine summarische Suche im Internet führt zu zahlreichen Online-CoachingAngeboten. Weitere Angebote mit einem bestimmten thematischen Fokus sind beispielsweise auf den Websites von Non-Profit-Organisationen zu finden. Oft werden kostenlose und dadurch niederschwellige Telefon-, Mail- oder ChatBeratungen angeboten (z. B. Beratung für Jugendliche: www.147.ch). Die Dargebotene Hand bietet in der Schweiz seit einigen Jahren neben der anonymen und kostenlosen Telefonberatung ihren Dienst auch per Chat an (www.143.ch), ganz ähnlich die Telefonseelsorge in Deutschland (https://www.telefonseelsorge.de).

Einen Überblick zur Marktsituation findet man bei Berninger-Schäfer (2018). In Australien und den USA ist Online-Coaching - hauptsächlich Telefonberatung - heute eine Selbstverständlichkeit. Im deutschsprachigen Raum konnten sich Online-Coaching-Angebote bisher deutlich weniger etablieren. In ihrer Diskussion der 14. Coaching-Umfrage von Middendorf geben Hinkelmann und Enzweiler (2016) an, dass immer noch 84 Prozent der befragten Coaches Face-to-Face-Coachings bevorzugen.

Im Gespräch mit Coaches zeigt sich aber, dass viele sich mit ihren Klient ${ }^{\star}$ innen per Telefon oder Mail austauschen. Dabei geht es nicht nur um Terminabsprachen, die Interaktionen enthalten durchaus auch beraterische Momente. So werden hybride Settings Teil des Coachingalltags, ohne dass die Coaches ihr Vorgehen als Online-Coaching bezeichnen.

Als Pioniere des Online-Coachings im deutschsprachigen Raum können sicherlich Berninger-Schäfer mit CAI (www.cai-world.com) und Geißler mit dem Virtuellen Coaching (www.virtuelles-coaching.com) gelten. Ansonsten ist ein rasch sich verändernder Markt zu beobachten, bei dem neue Angebote entstehen und bestehende Angebote wieder verschwinden.

\section{Wirkt Online-Coaching?}

Nimmt man die Anzahl der entsprechenden Angebote im Internet als Maßstab, müsste man eigentlich davon ausgehen, dass Online-Coaching wirkt. Belast- 
bare Evidenz zur Wirkung existiert aber noch sehr wenig. Eine gute, aber leider schon einige Jahre alte Übersicht zu verschiedenen Aspekten von OnlineCoaching findet sich bei Ghods und Boyce (2013). Dort wird allerdings neben einigen unpublizierten Dissertationen nur gerade eine Wirksamkeitsstudie (Bowles \& Picano, 2006) besprochen. Ein ganz anderes Bild ergibt sich in der Psychotherapie und der Verhaltensmedizin. Dort beschäftigt man sich schon seit Anfang der 90er Jahre mit der Frage, ob Online-Therapien wirken. Zu Beginn lagen nur einzelne Studien vor, seit 2000 nimmt ihre Anzahl stetig zu. Unterdessen existieren weit mehr als 250 Wirksamkeitsstudien zu ganz unterschiedlichen Störungsbildern und verhaltensmedizinischen Problemen (Andersson, 2016). Die Ergebnisse zeigen, dass die Behandlungseffekte mit denen konventioneller Therapien vergleichbar sind. Einschränkend muss erwähnt werden, dass es sich bei den Studien häufig um selbstselegierte Stichproben handelt, das heißt, die Studienteilnehmer*innen haben sich aus eigener Initiative für eine Teilnahme entschieden und waren dadurch möglicherweise besonders motiviert.

Bei den oben erwähnten Studien handelt es sich vorwiegend um Settings, bei denen der Kontakt mit den Therapeut ${ }^{\star}$ innen über ein Online-Medium (Telefon, Mail usw.) vermittelt wird. Seit einigen Jahren werden vermehrt sogenannt geleitete und ungeleitete Selbsthilfen untersucht. Bei Ersteren handelt es sich um Selbsthilfeansätze mit reduziertem Kontakt zwischen Therapeut ${ }^{\star}$ in und Klient* ${ }^{*}$ und Arbeit mit einer App in der Zwischenzeit. Bei Letzteren werden die Therapeut ${ }^{\star}$ innen vollständig ersetzt, und die Klient ${ }^{\star}$ innen arbeiten nur noch mit einer App oder einem Chatbot. Während die geleiteten Selbsthilfen recht kostengünstig sind, werden die großen Skaleneffekte mit den ungeleiteten Selbsthilfen erzielt. Sind solche Tools einmal erstellt, ist der potenzielle Nutzendenkreis nur noch durch die Sprache eingeschränkt. Ein weiterer großer Vorteil der ungeleiteten Selbsthilfen ist ihre Niederschwelligkeit. Die Nutzung ist anonym, und sobald man eingeloggt ist, kann man loslegen. Hier liegt aber auch die größte Schwäche solcher Tools. Die Abbruchraten sind relativ hoch. Man ist niemandem verpflichtet. Gefällt einem das Programm nicht, braucht es nur einen Mausklick, und man ist draußen. Während mit angeleiteten Selbsthilfen durchaus vergleichbare Resultate erzielt werden wie mit konventionellen Therapien, sind die Ergebnisse der ungeleiteten Selbsthilfen schwieriger einzuordnen, da sie recht stark streuen (vgl. z. B. Wahle, Bollhalder, Kowatsch \& Fleisch, 2017).

Noch wenig Forschung besteht zu sogenannt hybriden Settings, bei denen zum Beispiel therapeut ${ }^{*}$ innenunterstütztes Vorgehen (face-to-face oder online) mit ungeleiteten oder angeleiteten Selbsthilfen kombiniert wird. Es scheint durchaus denkbar, dass in solchen neu zu entwickelnden Settings viel Potenzial liegt. 
Die Frage, ob Online-Coaching wirkt, ist im Moment schwierig zu beantworten, da es dazu noch zu wenig Evidenz gibt. Der Analogieschluss, dass der aus der Therapie stammende Nachweis auch auf Coaching übertragen werden kann, weil es sich um ein ähnliches Format handelt, ist zwar plausibel und auch wahrscheinlich, aber vermutlich nicht zulässig. Die Praxis eilt hier der Forschung weit voraus. Den Praxistest hat Online-Coaching offenbar schon bestanden. Dies stimmt zwar zuversichtlich, ersetzt aber nach unserer Meinung nicht gute Wirksamkeitsstudien.

\section{Online-Coaching basiert auf computervermittelter Kommunikation}

Online-Coaching kann sich zu Beginn anfühlen wie das Eintauchen in eine verwandte, aber doch fremde Kultur. Computervermittelte Kommunikation (CVK) weist zwar Ähnlichkeiten mit Präsenzkommunikation aus, ist aber nicht "gleich«. Auskunft über diese »Andersartigkeit« geben verschiedene Theorien zur computervermittelten Kommunikation. Nachfolgend wird ein kurzer Überblick über ausgewählte Perspektiven und deren Entwicklung gegeben.

\section{Computervermittelte Kommunikation (CVK)}

Während frühe Theorien den Fokus deutlich auf die Mängel der CVK legen, schälen spätere auch ihren Mehrwert heraus. Alle weisen Ähnlichkeiten auf (für einen Überblick vgl. Trepte \& Reinecke, 2018). Allen liegt zugrunde, dass wir per Computer mit reduzierten sozialen Hinweisreizen kommunizieren. Dies steht im Zentrum des »Lack of Social Context Cues«-Ansatzes (Kiesler, Siegel \& McGuire, 1984). Dabei gehen laut Kiesler et al. (1984) sowohl Individualität als auch Normativität durch die fehlenden Hinweisreize (teilweise) verloren. Eine individuelle Ansprache wird schwieriger. Eine breitere Perspektive auf die Defizite der CVK wirft die Kanalreduktionstheorie (Trepte \& Reinecke, 2018). Sie geht davon aus, dass in Abhängigkeit von der Wahl des Kommunikationskanals Sinnesmodalitäten verloren gehen, womit sich Kommunikation reduziert. Es wird von einer Ent-Sinnlichung, Ent-Emotionalisierung, Ent-Kontextualisierung oder gar Ent-Menschlichung gesprochen. Durch die eingebaute technische Rationalität geht das typisch Menschliche - eben zum Beispiel die Emotionalität - verloren. Jedoch bleibt theoretisch unklar, warum beispielsweise ein getippter Text keine Gefühle transportieren, Intimität herstellen oder sinnliche Eindrücke erzeugen kann. Aus der Perspektive der Kanalreduktions- 
theorie wäre es quasi unmöglich, eine Brieffreundschaft aufzubauen oder (in der heutigen Zeit verbreiteter) eine mit intensiven Gefühlen verbundene Partnerschaft über das Internet zu entwickeln. Die Channel-Expansion-Theorie (Carlson \& Zmud, 1994) weitet den Blick. Sie besagt, dass nicht alleine die Reichhaltigkeit der Kommunikation, sondern auch die Erfahrung der Protagonisten eine Rolle spielt, wobei Erfahrung sowohl die Medienerfahrung umfasst als auch die Vertrautheit mit den Kommunikationspartner*innen. Die Kommunikation wird umso reichhaltiger wahrgenommen, je erfahrener die Protagonist*innen mit den ausgewählten Medien sind und je vertrauter die Protagonist*innen einander sind. Ein differenzierteres Bild der CVK entwirft Walther (2011) mit dem Hyperpersonal Model der CVK. Auch er geht davon aus, dass mit der CVK ein Verlust an sozialen Hinweisreizen einhergeht, er versucht jedoch, die psychologischen Prozesse, die während und nach der CVK zum Tragen kommen, zu integrieren. Das Modell besteht aus den vier Komponenten Sender, Empfänger, Kanal und Feedback. In der CVK kann der Sender auswählen, welche Hinweisreize gesendet werden sollen. Aus diesen selektierten Hinweisreizen baut der Empfänger ein tendenziell "geschöntes«, idealisiertes Bild des Senders auf, was zu einer besseren Trennung von aufgaben- und beziehungsorientierten Aspekten der Kommunikation (disentrainment) und beim Empfänger zu einer entspannteren Verarbeitung der Inhalte führt. Die Reziprozität (Feedback) von Selektion durch den Sender, die Idealisierung durch den Empfänger und disentrainment durch die Kanalwahl führen am Ende zu einer besser wahrgenommenen Kommunikation. Einschränkend ist hier anzumerken, dass sich das Hyperpersonal Model ausschließlich auf die textbasierte Kommunikation bezieht. Es scheint jedoch, dass sich die Grundgedanken auf jede Form der CVK übertragen lassen. Im Hinblick auf Online-Coaching kann davon ausgegangen werden, dass die Kommunikation präzise auf das Anliegen erfolgt. Das Phänomen der sozialen Erwünschtheit nimmt deutlich ab, und vor allem für schuld- und schambehaftete Themen kann es entlastend wirken, sich nicht persönlich gegenüberzusitzen.

Aufgrund von reduzierten oder fehlenden sozialen Hinweisreizen verändert sich die Kommunikation. Dies hat Vor- und Nachteile, deren man sich bewusst sein sollte. Je nach verwendetem Kanal entfallen zum Beispiel nonund paraverbale Signale. Im ersten Moment erschwert dies in der Regel den Kommunikationsfluss. Mit der Zeit kann man aber vermehrt die Vorteile, wie zum Beispiel das disentrainment, das heißt die stärkere Trennung von beziehungs- und aufgabenbezogenen Aspekten (stärkere Konzentration der Coachees auf sich selbst) nutzen. 


\section{Online-Beratungskompetenz}

Voraussetzung für Online-Coaching ist nicht der Erwerb von neuem Beratungswissen, sondern Gewandtheit im Umgang mit neuen Medien, kurz: Medienkompetenz.

\section{Medienkompetenz}

Gemäß Süss (2008) umfasst Medienkompetenz »die Fähigkeit, über Medien zu reflektieren (Medienkritik), ihre Produktionsbedingungen zu erkennen (Medienkunde), Medien für verschiedene Bedürfnisse adäquat zu gebrauchen (Mediennutzung) und Medien zur Kreation eigener Botschaften einzusetzen (Mediengestaltung)« (a. a. O., S. 362).

Fähigkeit zur Medienkritik kann als Voraussetzung für Online-Coaching betrachtet werden. Die Medienkunde ist von Bedeutung bei der Beurteilung und Auswahl der Coachinganwendungen. Hier gilt es besonders, den Datenschutz und die Datensicherheit sowie die rechtlichen Rahmenbedingungen zu erwähnen. Mit Mediennutzung und -gestaltung wird das "Handwerkszeug« eines Online-Coaches angesprochen. Professionelles Online-Coaching zeichnet sich nicht zuletzt dadurch aus, dass es einem Coach gelingt, die technischen Voraussetzungen, Möglichkeiten und Schwächen der CVK zu kennen, damit er sie optimal für das Coaching einsetzen kann. Dies ist in erster Linie ein Lernund Aneignungsprozess.

\section{Medienaneignung}

Das »Sich-zu-eigen-Machen « (Schulz, 2010, S. 234) wird als Medienaneignung bezeichnet. Es handelt sich um einen aktiven Prozess, bei dem Menschen die Medienangebote ergreifen, ihnen Bedeutung zuweisen und sie in ihren sozialen Alltag integrieren (a. a.O.). Coaches müssen sich mit den vorhandenen Kanälen und Möglichkeiten vertraut machen, sie müssen die Vorteile erkennen und lernen, diese zu schätzen und zu nutzen. Dabei können sie auf viel Bekanntes aufbauen. Dass Texte, Filme oder Bilder uns emotional berühren können, erfahren wir beim Lesen von Büchern oder Schauen von Filmen. Diese Alltagserfahrung, die wir mit Medien machen, muss nun in ein professionelles Setting transferiert werden, damit wir zielorientiert kommunizieren können. Das kann zum Beispiel bedeuten, dass grundlegende Beratungskompetenzen, wie zuhören, nachfragen können, einen Prozess durch metakommunikatives Handeln strukturieren, Gesprochenes auf sich wirken lassen und in Resonanz 
gehen zu können, in Abhängigkeit zum Kommunikationskanal weiter ausgebaut werden müssen, damit wir erfolgreich coachen können. Beim Telefoncoaching kann sich beispielsweise das Zuhören verändern, indem Coaches lernen, ganz genau hinzuhören und zu erkennen, ob sich die Stimmlage oder das Sprechtempo des Coachees verändert.

\section{Medienanpassung}

Wo die CVK an Grenzen stößt, gilt es, sich dem Medium so anzupassen, dass die im Präsenzcoaching eingesetzten Interventionen auch online erfolgreich angewendet werden können. Dies setzt bisweilen eine gewisse Kreativität im Umgang mit den neuen Technologien voraus. Wie kann ich als Coach zum Beispiel meine bewährten Körperübungen umsetzen? Wie erfahre ich bei fehlender physischer Präsenz, wie der Klient dasitzt? Wie ersetze ich körpersprachliche Hinweise? Zu solchen und ähnlichen Fragen gibt es verschiedene Vorgehensvorschläge, die von schriftlichen Aufgabenstellungen über den Einsatz von Emoticons bis hin zu kurzen Videosequenzen führen können, die den Klient ${ }^{\star}$ innen über die Coachingplattform zugänglich gemacht werden können.

\section{Konsequenz: Weiterentwicklung der Online-Coaching-Kompetenzen}

Was braucht es nun für erfolgreiches Online-Coaching? Neben soliden Beratungskompetenzen, Wissen zu rechtlichen, technischen und Sicherheitsaspekten vor allem Medienkompetenzen. Medienkunde kann vermittelt werden. Medienaneignung und -anpassung müssen erfahren werden. Eine differenzierte Medienkritik entwickelt sich nach unserer Ansicht im Aneignungs- und Anpassungsprozess.

\section{Weiterbildungskurs am Zürcher Institut für Angewandte Psychologie}

Obige Leitlinien werden am Weiterbildungskurs Online-Beratung am Institut für Angewandte Psychologie (IAP) der Zürcher Hochschule für Angewandte Wissenschaften (ZHAW) umgesetzt. Der Kurs richtet sich an erfahrene Coaches und Psychotherapeut*innen. Ziel des Angebots ist es, dass die Teilnehmenden die für Online-Coaching nötigen Zusatzkompetenzen entwickeln können.

Der Kurs wird mit der Plattform CAI (www.cai.com) durchgeführt. CAI stellt verschiedene Kommunikationskanäle (Mail, Chat, Video, Audio) und für 
die Beratungsarbeit mehrere Tools zur Verfügung (z. B. Whiteboard, Inneres Team usw.), die Datensicherheit ist gewährleistet (SSL-Verschlüsselung), und die Server stehen in der Schweiz.

Die Weiterbildung besteht aus vier Blöcken (siehe Abbildung 1). Nach einer »Einführung " (Block 1) sind die weiteren drei Blöcke entlang der Kommunikationskanäle strukturiert. Während der Weiterbildung führen die Teilnehmenden ein für ihren Arbeitsalltag typisches Online-Coaching durch. Die Herausforderungen und Chancen werden in Online-Erfahrungsaustauschtreffen reflektiert.

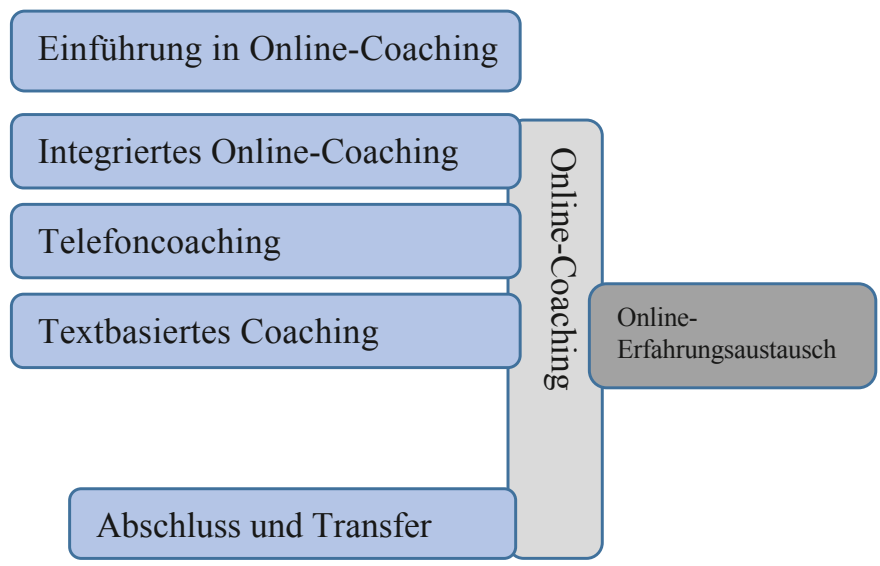

Abbildung 1: Struktur der Weiterbildung am IAP/ZHAW

Inhalte des ersten Blocks sind: Einführung in die Plattform, Datensicherheit, rechtliche und technische Fragen (z.B. Umgang mit nicht funktionierendem Audiokanal), Stand der Wirkungsforschung, Beziehungsaufbau und Beziehungsgestaltung über die Distanz, Theorien der CVK und konkrete Beratungsübungen. Im Block »Integriertes Online-Coaching « lernen die Teilnehmenden das CAIKonzept kennen. Im Block zum textbasierten Coaching wird auf die Besonderheiten von Mail- und Chat-Coaching eingegangen. Im Block»Telefoncoaching « trainieren die Teilnehmenden vor allem das differenzierte Zuhören. Eine Orientierungshilfe für die Übungen waren uns vor allem Knatz (2013) sowie Kühne und Hintenberger $(2009,2013)$. Beim Abschlusstermin steht der Transfer in den eigenen Arbeitskontext im Zentrum. Wichtige Themen sind hier unter anderem die Einbindung der Online-Beratung in die lokale Prozess- und IT-Struktur, die Gestaltung des Coachingprozesses, die Ausbildung der Mitarbeitenden, die technische Ausstattung der Arbeitsplätze und die Besonderheiten der Zielgruppen, die angesprochen werden sollen. 


\section{Ausblick}

Gerade weil ein professionelles Online-Coaching besondere Anforderungen an Coaches stellt und gleichzeitig davon auszugehen ist, dass Online-Coaching in der Zukunft einen größeren Stellenwert einnehmen wird, scheint es unumgänglich, Fachleute in den spezifischen Kompetenzen zu schulen, die dafür vorausgesetzt sind. Im Masterstudiengang in Angewandter Psychologie der ZHAW ist Distanzberatung seit 2012 ein Pflichtfach. Ähnlich wie im vorgestellten Weiterbildungskurs lernen die Studierenden nicht nur Theorien und Grundlagen kennen, sondern müssen durch Übungen »ins Tun kommen« und eine Beratung mit ihnen unbekannten Klient*innen durchführen. Die Erfahrung zeigt, dass sich die Einstellung zu Online-Coaching durch das Tun verändert. Ähnliches berichten Ribbers und Waringa (2015): »However, once they got started with it, their enthusiasm grew rapidly« (a. a. O., S. 70).

Der vorliegende Beitrag bezog sich ausschließlich auf Online-Coaching, bei dem die Protagonist ${ }^{\star}$ innen per Computer kommunizieren. Diese Form des OnlineCoachings steht erst am Anfang ihrer Entwicklung. Die Technik schreitet mit hohem Tempo voran. Bereits seit einigen Jahren werden zum Beispiel soziale Phobien mithilfe von Virtual Reality therapiert (Herbelin, Riquier, Vexo \& Thalmann, 2002). Der Vorteil ist unübersehbar, Patient ${ }^{\star}$ innen können sich virtuell (mithilfe von VR-Brillen) in den Therapieräumlichkeiten in die für sie herausfordernden Situationen begeben und diese aktiv steuern. Neben Virtual Reality werden Chatbots, Sensortechnik und der Einsatz von künstlicher Intelligenz in Zukunft das Feld der Möglichkeiten erweitern. Welche Auswirkungen diese Entwicklungen auf das künftige Kompetenzprofil von Online-Coaches haben könnte, wird heute noch kaum diskutiert und bleibt derzeit deshalb noch offen.

\section{Literatur}

Andersson, G. (2016). Internet-Delivered Psychological Treatments. Annual Review of Clinical Psychology, 12, 157-179.

Berger, T. (2018). Die therapeutische Beziehung in internetbasierten Behandlungsansätzen. In H. Bents, A. Kämmerer (Hrsg.), Psychotherapie und Würde (S. 105-117). Berlin, Heidelberg: Springer.

Berninger-Schäfer, E. (2018). Online-Coaching. Wiesbaden: Springer.

Bowles, S. V., Picano, J. J. (2006). Dimensions of coaching related to productivity and quality of life. Consulting Psychology Journal: Practice and Research, 58 (4), 232-239. DOI: 10.1037/10659293.58.4.232 
Carlson, J. R., Zmud, R. W. (1994). Channel expansion theory: a dynamic view of medial and information richness perceptions. Academy of Management Proceedings, (1), 280-284.

Ghods, N., Boyce, C. (2013). Virtual Coaching and Mentoring. In J. Passmore, D. B. Peterson, T. Freire (Eds.), The Wiley-Blackwell Handbook of Psychology of Coaching and Mentoring (pp. 501-523). Oxford: Wiley-Blackwell.

Herbelin, B., Riquier, F., Vexo, F., Thalmann, D. (2002). Virtual reality in cognitive behavioral therapy: a preliminary study on social anxiety disorder. $8^{\text {th }}$ International Conference on Virtual Systems and Multimedia (VSMM 2002), Gyeongju, 25-27 September 2002.

Hinkelmann, R., Enzweiler, T. (2016). Digitale Entwicklung: Chancen und Risiken virtuellen Coachings. Coaching-Newsletter von Christopher Rauen, (Juli/August), 1-4.

Kiesler, S., Siegel, J., McGuire, T. W. (1984). Social psychological aspects of computer-mediated communication. American Psychologist, 39 (10), 1123-1134.

Knatz, B. (2013). Handbuch Internetseelsorge. Grundlagen, Formen, Praxis. Gütersloh: Gütersloher Verlagshaus.

Kühne, S., Hintenberger, G. (2009). Handbuch Online-Beratung. Psychosoziale Beratung im Internet (2. Auflage). Göttingen: Vandenhoeck \& Ruprecht.

Kühne, S., Hintenberger, G. (2013). Professionalisierung der Online-Beratung. In F. Nestmann, F. Engel, U. Sickendiek (Hrsg.), Das Handbuch der Beratung. Band 3. Neue Beratungswelten (S. 1571-1586). Tübingen: dgvt.

Ribbers, A., Waringa, A. (2015). E-Coaching: Theory and practice for a new online approach to coaching. London: Routledge.

Schulz, I. (2010). Mediatisierung und der Wandel von Sozialisation: Die Bedeutung des Mobiltelefons für Beziehungen, Identität und Alltag im Jugendalter. In M. Hartmann, A. Hepp (Hrsg.), Die Mediatisierung der Alltagswelt (S. 231-242). Wiesbaden: VS Verlag für Sozialwissenschaften.

Süss, D. (2008). Mediensozialisation und Medienkompetenz. In B. Batinic, M. Appel (Hrsg.), Medienpsychologie (S. 361-378). Berlin, Heidelberg: Springer.

Trepte, S., Reinecke, L. (2018). Medienpsychologie. Stuttgart: Kohlhammer.

Wahle, F., Bollhalder, L., Kowatsch, T., Fleisch, E. (2017). Toward the Design of Evidence-Based Mental Health Information Systems for People With Depression: A Systematic Literature Review and Meta-Analysis. Journal of medical Internet research, 19 (5), e191. DOI: 10.2196/ jmir.7381

Walther, J. B. (2011). Theories of Computer-Mediated Communication and Interpersonal Relations. In M. L. Knapp, J. A. Daly (Eds.), The Handbook of Interpersonal Communication (pp. 443479). Thousand Oaks, CA: Sage. 


\section{Digital coaching: A conceptually distinct form of coaching?}

Stella Kanatouri

The value of coaching as an approach to human development is increasingly acknowledged. Using technology to facilitate the coaching dialogue and to support coaching processes adds flexibility and allows to expand the reach to wider audiences. Whilst the practicality of digital coaching is obvious and indisputable, understanding the role of coaching media and the experiences they can produce may be useful for this form of coaching practice to be optimised. This paper draws on media theories and adopts a phenomenological view of media to reflect on what happens when the coaching process, or aspects of it, is digitalised. It seeks to explore the connection between media capabilities and coaching skills in a digital coaching context, and it approaches digital coaching as a distinct concept of traditional, presence coaching.

As the demand for coaching has been growing over the years (Bresser, 2013; ICF $\& \mathrm{PwC}, 2012$, 2016), the addition of technology in coaching practice enables us to expand coaching offerings on more layers of the organisation and on larger portions of the population, allowing scalable coaching, independent of geography and time zones. Beyond its undeniable practicality however, digitalising the coaching process or aspects of it raises important questions: What changes when the coaching process takes place remotely in a virtual space? How might new media shape the coaching experience? Given the diversity of technological coaching media and their evolving capabilities, the answer to these questions is complex. Different media may produce different experiences. Nevertheless, such questions need to be addressed if we are to seamlessly integrate new media in the coaching process and to optimise mediated coaching practice. 


\section{Media use in coaching}

What do we mean by "media«? The meaning of media has been conceptualised in different ways in communication literature. Shannon and Weaver (1963) and Clark $(1983,1985)$ understood media as the means of transmitting and receiving communication messages like parcels (Reddy, 1979), whereby the nature of the media has no influence on the communication or learning process. Based on this view, the receiver passively consumes the message as it was transmitted, and regardless of whether the medium accommodates written, auditory or audio-visual cues. Another perspective would see the receiver play an active, constructive role in the communication process (Kozma, 1991, p. 179), acknowledging that the intended message being transmitted may differ from the interpretation of the message by the receiver, as for instance when the sender insinuates something, or uses a metaphor, or is being ironic (Searle, 1975, p. 59). As implied in this view, communication may be explicit as well as implicit, and its effectiveness depends upon the congruence between these two aspects (Watzlawick, Beavin, \& Jackson, 1967).

To understand not only the explicit messages but also the sender's intentions and more implicit messages, it may make intuitive sense that media, which accommodate multiple sensory cues, are helpful. As Daft and Lengel (1986) proposed and empirically demonstrated (Daft, Lengel, \& Trevino, 1987; Lengel \& Daft, 1988), rich media, in other words media which allow multiple sensory cues and immediate feedback (e.g. face-to-face communication), are more suitable for resolving uncertainty and ambiguity than lean media (e.g. online text media); the latter being better suited for objective data transmission. In a similar vein, the earlier theoretical model by Short, Williams and Christie (1976) proposed that media affect interpersonal communication based on their levels of social presence, "the degree of salience of the other person in the interaction « (op. cit., p. 65), which might be achieved through eye contact and physical proximity (face-to-face contact) and through both verbal and non-verbal communication messages. From this perspective, seen along a continuum, face-to-face contact allows a higher degree of social presence and offers a higher level of richness than video communication, followed by audio-based media and subsequently by online text-based communication, which may be considered impersonal and devoid of non-verbal cues (Walther \& Parks, 2002).

Nevertheless, numerous empirical studies (a.o. Dennis \& Kinney, 1998; Hancock, Thom-Santelli, \& Ritchie, 2004; Kinney \& Watson, 1992) rejected that lean media are necessarily less appropriate for resolving complex situations than rich 
media. Even though face-to-face media allow verbal and non-verbal communication, and thereby for more information to be transmitted at a time, leaner media, such as computer-mediated communication via text, could lead to equally strong relationships, self-disclosure, trust and social presence as face-to-face communication (Gunawardena, 1995; Gunawardena \& Zittle, 1997), despite the fact that relationships over computer-based text media may indeed take longer to be established (Walther, 1990, 1992). These observations have also been empirically supported by counselling and psychotherapeutic research (a.o. Barak, Hen, Boniel-Nissim, \& Shapira, 2008; Cook \& Doyle, 2002; Murphy, Mitchell, $\&$ Hallett, 2011; Rice \& Love, 1987). Besides, it is worth noting that visual contact is not always appropriate for all tasks - for instance, in some cases it might be less comfortable for discussing embarrassing issues (Amichai-Hamburger, Klomek, Friedman, Zuckerman, \& Shani-Sherman, 2014).

Given that a supporting relationship to the client is fundamental to coaching (Rogers, 1959; Schmidt, Thamm, \& Greif, 2008; Stober, 2006), the empirical insights about the viability of leaner media to support equally strong rapport to rich media are very relevant, as they increase confidence that technology-mediated communication involving limited sensory cues does not necessarily constrain the coaching relationship. Whilst empirical research specifically about the efficacy of technology-based forms of coaching is scarce, there is at least some evidence to suggest that leaner media (such as telephone and online text) can be viable for developing strong rapport and for facilitating positive coaching outcomes (Berry, 2005; Geißler, Hasenbein, Kanatouri, \& Wegener, 2014; Ghods, 2009; McLaughlin, 2012; Poepsel, 2011). With this evidence in mind, it is worth exploring the potential of diverse media that can be used to support coaching and considering the different roles they may play in the coaching process, as they display different functions, qualities and structures.

\section{Mapping coaching media}

Digitalising the coaching process or certain aspects of it can take different forms, ranging from (i) face-to-face coaching combined with digital media use, (ii) blended coaching, which involves alternating face-to-face with remote sessions, (iii) remote coaching processes (iv) to online self-coaching programs, which may or may not be combined with coaching facilitated by a coach (Kanatouri \& Geißler, 2016, p. 714). Technological media can be used to facilitate the coaching conversation (basic media) or to complement and enrich the client's problem-solving and reflection process beyond the coaching dialogue (problem-solving media) (Geißler, 2014, p. 149). Basic media such as, for instance, tele- 
phone, e-mail, video communication, synchronous text chat or asynchronous voice messages are essential to any remote coaching process that is facilitated by a coach. Table 1 lists some of the different types of basic media that are used to facilitate the coaching dialogue.

Table 1: Basic media types to facilitate the coaching dialogue

\begin{tabular}{|l|l|l|l|l|}
\hline & $\begin{array}{l}\text { Video } \\
\text { communication }\end{array}$ & $\begin{array}{l}\text { 3D graphical self- } \\
\text { representation }\end{array}$ & $\begin{array}{l}\text { Audio } \\
\text { communication }\end{array}$ & $\begin{array}{l}\text { Text-based } \\
\text { communication }\end{array}$ \\
\hline Synchronous & $\begin{array}{l}\text { Video calls, HD } \\
\text { videoconferencing }\end{array}$ & $\begin{array}{l}\text { (Desktop-based } \\
\text { or through HMD) } \\
\text { avatar-centric } \\
\text { interaction (with } \\
\text { built-in audio or } \\
\text { text chat) }\end{array}$ & Telephone/VolP & $\begin{array}{l}\text { Synchronous text } \\
\text { chat }\end{array}$ \\
\hline Asynchronous & $\begin{array}{l}\text { Asynchronous } \\
\text { video messages }\end{array}$ & Audio messages & $\begin{array}{l}\text { Asynchronous text } \\
\text { chat/e-mail }\end{array}$ \\
\hline
\end{tabular}

Problem-solving media can be used during the coaching session or in-between sessions, and they tend to serve as a complementary function to the coaching dialogue. For instance, online text-based questions and reflective journals may be used as add-ons in-between coaching sessions to support clients' thought process and to scaffold their learning process by breaking it into small, manageable steps. Visualisation aids, such as mind-mapping software and whiteboard tools, can be used to stimulate reflection on the coaching issue, to support the analysis of the coaching problem and to identify a course of action. Alternatively, simulations allow perspective-taking, role-play, the creation of visual metaphors and to test out potential solutions. Table 2 illustrates the diverse types of problem-solving media.

Table 2: Supporting media types to complement the coaching conversation

\begin{tabular}{|l|l|l|l|l|}
\hline \multicolumn{2}{|l|}{ Audio-visual } & Visual & Auditory & Text \\
\hline $\begin{array}{l}\text { Interactive/ } \\
\text { non-interactive } \\
\text { videos }\end{array}$ & $\begin{array}{l}\text { 3D simulations } \\
\text { (virtual worlds, } \\
\text { constellation } \\
\text { tools) }\end{array}$ & $\begin{array}{l}\text { Visualisation aids } \\
\text { (graphs, online } \\
\text { images, mind } \\
\text { maps, whiteboard } \\
\text { sketches) }\end{array}$ & Podcasts & $\begin{array}{l}\text { Pre-defined online } \\
\text { question sets, } \\
\text { reflective journals, } \\
\text { online resources } \\
\text { (blogs, articles), } \\
\text { pre-coaching } \\
\text { assessments }\end{array}$ \\
\hline
\end{tabular}

Moreover, problem-solving media, such as sets of questions that guide the client from goal clarification and goal setting through to setting an action plan to attain a goal, can be used for self-coaching (see table 3). 
Table 3: Types of self-coaching programmes and resources

\begin{tabular}{|l|l|l|l|}
\hline Audio-visual & Visual & Auditory & Text \\
\hline Videos & $\begin{array}{l}\text { Visualisation aids (e.g. } \\
\text { a wheel of resources } \\
\text { in some self-coaching } \\
\text { apps) }\end{array}$ & Podcasts & $\begin{array}{l}\text { Pre-set question } \\
\text { frameworks }\end{array}$ \\
& & - Coaching chatbots \\
\hline
\end{tabular}

Each of the media types described in this section may have a place in supporting aspects of the coaching process. However, as they address distinct sensory qualities and bodily experiences, different media produce different experiences. For instance, the same coaching contents may be perceived differently when read in an e-mail than when conveyed in real-time through a video encounter. These differences are explored in the following section.

\section{How digital media shape the coaching experience ${ }^{1}$}

With his concept of Being-in-the-world, Heidegger (1962) noted that the human being makes sense of things, while essentially always being situated and immersed in the world. This relation between human and lifeworld can be mediated through technology. In its mediating role, technology transforms human experience (Ihde, 1979). So, how might the earlier discussed different types of technologies mediate and shape the coaching experience?

The role of technological media as the means to human experience has been explained by Ihde's $(1979,2013)$ different types of human-technology relations, out of which embodiment relations, hermeneutic relations and alterity relations are of particular interest for coaching:

Embodiment relations: In this type of symbiotic human-technology relation, technology becomes perceptually transparent (Ihde, 2013, p. 8), in the sense that it tends to withdraw from our awareness. Ihde $(1979,2013)$ used the characteristic example of the telescope, which creates a transformed view of the world and one that differs from the view one would see through their eyes only. In this example, one becomes less aware of the telescope, or otherwise said, the telescope becomes transparent as one sees through it (Ihde, 2013, p. 10). Transferring this to a coaching context, the technology that mediates the coach's or the client's experience retracts to the background as the coach or client embodies the technology. The coach speaks through the telephone to the client or sees the client through the screen in a video call. The client experiences a virtual world by manipulating the physical interface that is the computer. While the clients

1 Parts of this section appear in Kanatouri, S. (2020). The Digital Coach. London: Routledge. 
focus on the computer, what they actually "see" is the virtual world that the technology transfers them to. Arguably, the more embodied a technology is, the more seamless the experience has the potential to be, in a way that we hardly notice the technology. For instance, a Head Mounted Display might become more perceptually transparent and might allow a more immersive experience than when looking at the virtual world on a flat computer screen. In this sense, a Head Mounted Display amplifies the experience of a virtual environment. There is an obvious embodiment relation between the coaching client and the avatar, particularly in immersive Virtual Reality technology where the client embodies an avatar (first-person perspective) to explore and interact with a virtual world. The human client's physical head and hand movements are represented without time lag in the virtual environment, creating an illusion of »being « there.

The perceptual transparency of media, however, may be affected by their technical quality and ease of use. The higher the technical quality and user-friendliness of the medium, the more transparent the experience of the medium is likely to become, whilst technical limitations or complex use can make us perceptually aware of the medium. Poor image quality or a technical disruption due to a poor Internet connection during a Skype video call, or a Head Mounted Display feeling heavy and uncomfortable or causing nausea, or the learning curve involved in mastering the right finger taps in the Microsoft Hololens are all examples where the »symbiosis« of human and technology may be disturbed.

Hermeneutic relations: A hermeneutic relation according to Ihde (1979) involves reading and interpreting the technology, which represents information about the world before we can apply the information, as for instance, a thermometer or a compass. Coaching tools that involve hermeneutic relations include visualisations, such as graphs, drawings and progress charts, as well as text-based contents, all of which represent information. For instance, in using a journaling software, the coaching client's journal entry requires interpretation by the coach to obtain insights into the client's emotional states and thought processes. The coach's relation to the medium is a hermeneutic one, as it involves reading the information that represents the client's world. Text media reduce the coaching experience to the written word. The client/coach is disembodied when using text-based media, as neither the body and face of the communication partner are visible, nor the voice can be used to convey meaning. On the other hand, the disembodiment that the client/coach experiences allows distance and thereby space to reflect and articulate thoughts.

The hermeneutic human-technology relation in the context of coaching emphasises the importance of clarity, methodical use and structure of coaching media. What becomes important, for instance, when text-based question 
sets are used to support the clients' reflection processes is how understandable, precise and clear the questions are, and how they are structured based on coaching methodology to support the clients' outcome-oriented reflection processes.

Alterity relations: Ihde (1990) discussed alterity relations that emerge in technologies, which display a »quasi-other « quality and behaviour. In the example of avatar-based coaching, to be able to act within a virtual world, the client needs to merge with the avatar. Whilst this is a clear embodiment relation between the coaching client and the avatar, the relation between human and avatar is also an alterity relation. Using the ProReal software, an avatar-based virtual environment designed for coaching and counselling, coaching clients view the representation of themselves (their avatar) from a first or a third-person perspective, and they may give their avatar a colour, a size, a posture and a caption. These attributes are supposed to match the clients' emotional states. The avatar becomes a technological extension of the client, a »quasi-other « which resembles the client, but it might display a different behaviour than the client would display in the physical world. This relation can also be reversed: How might the clients' cognitive or emotional states change if the clients change the appearance of their avatar to match their desired state? For instance, could creating a very tall avatar give the client a sense of confidence? In both cases, the experience of »being « in the virtual world is shaped by the connection between the client and the avatar.

A chatbot is another clear example of what Ihde sees as the "quasi-other«. Clients' interactions with coaching chatbots (e. g. PocketConfidant, Butterfly.ai, or Saberr's CoachBot) can be understood as alterity interactions, because chatbots are experienced as something more than just a computer program. They may be experienced as having a humanoid presence, an autonomy to ask reflective questions, and perhaps in the future, as having a consciousness. The implication of chatbots and avatars in coaching is that quasi-otherness influences the clients' relation to technology, and it shapes their coaching experience. The anonymity, humanoid presence and reaction of the chatbot to the client could potentially encourage the client's openness and self-disclosure. Or the representation of the client as an avatar and seeing one's avatar interact with the virtual world might lead to new insights about oneself.

\section{The digital coach}

As discussed in the previous section, the sensory qualities of different media may amplify, or they may reduce the experience, and the perceptual awareness 
of digital media differs based on whether technology is embodied, or used as a means to interpret information, or as an interaction with the technological "other" (note that different human-technology relations may co-exist). The relation between coach/client and technology is not only shaped by the fixed capabilities of digital media but quite likely also by experiential factors. Carlson and Zmud (1999) and subsequent empirical studies (a.o. D'Urso \& Rains, 2008; Timmermann \& Madhavapeddi, 2007) demonstrated that user experience with a medium can affect their perception of the medium's richness. As users accumulate experiences with a medium, with the topic and with an interlocutor, they develop knowledge bases that allow them to encode and decode rich messages and communicate effectively (Carlson \& Zmud, 1999). This suggests that it is possible to adapt to the media in use and to develop strong relationships, despite limited sensory cues (Walther, 1992).

Adapting to mediated coaching practice means not only becoming familiar with media and developing an understanding of their capabilities and their boundaries but potentially also developing enhanced coaching skills, both listening skills and language skills (Kanatouri, 2018, 2020). Whilst these core skills are common to any form of coaching, the digital coach compensates for the limited sensory cues by developing, for instance, a heightened awareness for the clients' tone of voice, speed of speaking, silent moments, choice of words, or by developing strong reading, writing or verbal language skills, and using clear and descriptive language. Even though the technical quality of digital media and their design can play a role in making them more »transparent « and a seamless means to the coaching experience, it is also up to the coach's skill to overcome some of the challenges added by technology, such as the limited sensory information and lack of physical proximity. A coaching practice that is adapted to new media makes methodologically structured use of coaching contents (Geißler, in Vorb.). This is achieved by the coach's expertise and skill, whether the medium involves pre-defined coaching contents, thus, it incorporates coaching expertise and methods, or it is content free but requires the coach's method and skill in order to effectively guide the client's reflection and problem-solving process. In both cases, the coaching methodology and skill are used to shape the media in use and to structure the coaching process.

The differences in digital coaching experiences that result from the coaching pair's relation to the medium, from the challenges and complexity added by technology and from the need to adapt core coaching skills in order to overcome challenges, point us towards re-thinking the meaning of digital coaching as a conceptually distinct form of coaching practice compared to traditional, face-to-face coaching; a form of practice where the mediated experience alters 
the coaching interaction in ways that may challenge coaches and call for them to develop enhanced skills.

There are several issues to be addressed if digital coaching practice is to mitigate its challenges. Given that technology is a moving target, coaches need to maintain an overview of the plethora of digital tools available and have to develop their ability to evaluate different tools, in terms of the suitability for their clients' individual needs. Offering specialised training might be useful to support coaches in evaluating the different tools, adapting their skills, understanding how to build rapport and to offer support via different media. Ethical issues that could arise through the use of technology should also not be neglected and should be included in the coach training curriculum. Finally, the way and the extent to which media attributes or coaching skill, or the interplay between the two, affect the coaching experience warrants further investigation.

\section{References}

Amichai-Hamburger, Y., Klomek, A. B., Friedman, D., Zuckerman, O., Shani-Sherman, T. (2014). The future of online therapy. Computers in Human Behaviour, 41, 288-294.

Barak, A., Hen, L., Boniel-Nissim, M., Shapira, N. (2008). A comprehensive review and a meta-analysis of the effectiveness of internet-based psychotherapeutic interventions. Journal of Technology in Human Services, 26 (2-4), 109-160.

Berry, R. M. (2005). A comparison of face-to-face and distance coaching practices: The role of the working alliance in problem resolution. Unpublished doctoral dissertation, Georgia State University, Atlanta, GA.

Bresser, F. (2013). The state of coaching across the globe: Results of the Global Coaching Survey 2008/2009 (August 2009). https://cdn.ymaws.com/www.associationforcoaching.com/resource/ resmgr/Research/globalcoachingsurvey09-execu.pdf [9.4.2020].

Carlson, J. R., Zmud, R. W. (1999). Channel expansion theory and the experiential nature of media richness perceptions. The Academy of Management Journal, 42 (2), 153-170.

Clark, R. E. (1983). Reconsidering research on learning from media. Review of Educational Research, 53 (4), 445-459.

Clark, R. E. (1985). Confounding in educational computing research. Journal of Educational Computing Research, 1 (2), 137-148.

Cook, J., Doyle, D. (2002). Working alliance in online therapy as compared to face-to-face therapy: Preliminary results. CyberPsychology and Behavior, 5 (2), 95-105.

Daft, R. L., Lengel, R. H. (1986). Organizational Information Requirements, Media Richness and Structural Design. Management Science, 32 (5), 554-571.

Daft, R. L., Lengel, R. H., Trevino, L. K. (1987). Message equivocality, media selection, and manager performance: Implications for information systems. MIS Quarterly, 11 (3), 355-366.

Dennis, A. R., Kinney, S. T. (1998). Testing media richness theory in the new media: The effects of cues, feedback, and task equivocality. Information Systems Research, 9 (3), 256-274.

D'Urso, S. C., Rains, S. A. (2008). Examining the scope of channel expansion: A test of channel expansion theory with new and traditional communication media. Management Communication Quarterly, 21 (4), 486-507. 
Geißler, H. (2014). Traditionelle und moderne Medien im Coaching. In R. Wegener, A. Fritze, M. Loebbert (Hrsg.), Coaching-Praxisfelder: Forschung und Praxis im Dialog (S. 135-158). Wiesbaden: Springer.

Geißler, H. (in Vorbereitung). Coaching: Methodische Gestaltung elektronischer Coachingmedien. Studienbrief, Hamburger Fern-Hochschule (HFH), Hamburg.

Geißler, H., Hasenbein, M., Kanatouri, S., Wegener, R. (2014). E-coaching: Conceptual and empirical findings of a virtual coaching programme. International Journal of Evidence Based Coaching and Mentoring, 12 (2), 165-187.

Ghods, N. (2009). Distance coaching: The relationship between coach-client relationship, client satisfaction, and coaching outcomes. Unpublished doctoral dissertation, San Diego University, San Diego, CA.

Gunawardena, C. N. (1995). Social presence theory and implications for interaction and collaborative learning in computer conferences. International Journal of Educational Telecommunications, $1(2 / 3), 147-166$.

Gunawardena, C. N., Zittle, F. J. (1997). Social presence as a predictor of satisfaction within a computer-mediated conferencing environment. The American Journal of Distance Education, 11 (3), 8-26.

Hancock, J. T., Thom-Santelli, J., Ritchie, T. (2004). Deception and design: The impact of communication technologies on lying behavior. In E. Dykstra-Erickson, M. Tscheligi (Eds.), Proceedings of the ACM conference on human factors in computing systems, 6 (pp. 130-136). New York: ACM.

Heidegger, M. (1962). Being and Time. Oxford: Blackwell.

ICF/PwC (International Coaching Federation/PricewaterhouseCoopers) (2012). 2012 ICF Global Coaching Study. www.coachfederation.org/coachingstudy2012 [20.2.2020].

ICF/PwC (International Coaching Federation/PricewaterhouseCoopers) (2016). 2016 ICF Global Coaching Study. https://coachfederation.org/app/uploads/2017/12/2016ICFGlobalCoachingStudy_ExecutiveSummary-2.pdf [20.2.2020].

Ihde, D. (1979). Technics and Praxis. Dordrecht: D. Reidel Publishing.

Ihde, D. (1990). Technology and the lifeworld: From garden to earth. Bloomington, Indianapolis, IN: Indiana University Press.

Ihde, D. (2013). Technics and Praxis (2nd ed.). Dordrecht: D. Reidel Publishing.

Kanatouri, S. (2020). The Digital Coach. London: Routledge, Taylor \& Francis.

Kanatouri, S. (2018). Mapping the technology-assisted coaching field through the lens of an online community: An exploratory study. Unpublished dissertation, Helmut-Schmidt University/University of the Federal Armed Forces, Hamburg.

Kanatouri, S., Geißler, H. (2016). Adapting to working with new technologies. In T. Bachkirova, G. Spence, D. Drake (Eds.), The Sage handbook of coaching (pp. 715-730). London: Sage.

Kinney, S. T., Watson, R. T. (1992). The effect of medium and task on dyadic communication. International Conference on Information Systems (ICIS) 1992 Proceedings, 10. http://aisel.aisnet.org/ cgi/viewcontent.cgi?article $=1050 \&$ context=icis 1992 [10.11.2016].

Kozma, R. B. (1991). Learning with media. Review of Educational Research, 61 (2), 179-211.

Lengel, R. H., Daft, R. L. (1988). The Selection of Communication Media as an Executive Skill. Academy of Management Executive, 2 (3), 225-232.

McLaughlin, M. (2012). Less is more: The executive coach's experience of working on the telephone. Unpublished Master's thesis, Oxford Brookes University, UK.

Murphy, L. J., Mitchell, D. L., Hallett, R. H. (2011). A comparison of client characteristics in cyber and in-person counselling. Studies in health technology and informatics, 167 (1), 149-153.

Poepsel, M. (2011). The impact of an online evidence-based coaching program on goal striving, subjective well-being, and level of hope. Doctoral dissertation, Capella University, Minneapolis, MN.

Reddy, M. (1979). The conduit metaphor. In A. Ortony (Ed.), Metaphor and thought. Cambridge: Cambridge University Press. 
Rice, R. E., Love, G. (1987). Electronic emotion: Socioemotional content in a computer-mediated communication network. Communication Research, 14 (1), 85-108.

Rogers, C. R. (1959). A theory of therapy, personality and interpersonal relationships. In S. Koch (Ed.), Psychology: A study of science (pp. 184-256). New York: McGraw-Hill.

Schmidt, F., Thamm, A., Greif, S. (2008). Rating-Manual der Wirkfaktoren im Coaching. In F. Schmidt, A. Thamm (Hrsg.), Wirkungen und Wirkfaktoren im Coaching: Verringerung von Prokrastination und Optimierug des Lernverhaltens bei Studierenden. Osnabrück: University of Osnabrück.

Searle, J. R. (1975). Indirect speech acts. In P. Cole, J. L. Morgan (Eds.), Syntax and semantics, 3: Speech acts (pp. 59-82). New York: Academic Press.

Shannon, C. E., Weaver, W. (Eds.) (1963). The mathematical theory of communication. Urbana, IL: The University of Illinois Press.

Short, J., Williams, E., Christie, B. (Eds.) (1976). The social psychology of telecommunications. London: Wiley.

Stober, D. R. (2006). Coaching from the humanistic perspective. In D. R. Stober, A. M. Grant (Eds.), Evidence-Based Coaching Handbook (pp. 17-50). New York: Wiley.

Timmermann, S. E., Madhavapeddi, S. N. (2007). Perceptions of organizational media richness: Channel expansion effects for electronic and traditional media across richness dimensions. IEEE Transactions on Professional Communication, 51 (1), 18-32.

Walther, J. B. (1990). Relational communication in computer-mediated interaction. Doctoral dissertation, University of Arizona, Tucson, AZ.

Walther, J. B. (1992). Interpersonal effects in computer-mediated interaction: A relational perspective. Communication Research, 19 (1), 52-90.

Walther, J. B., Parks, M. R. (2002). Cues filtered out, cues filtered in. In M. L. Knapp, J. A. Daly (Eds.), Handbook of interpersonal communication (pp. 529-563). Thousand Oaks, CA: Sage.

Watzlawick, P., Beavin, J. H., Jackson, D. D. (1967). Pragmatics of human communication: A study of interactional patterns, pathologies, and paradoxes. New York: Norton \& Company. 


\title{
Chatbots as an instance of an artificial intelligence coach
}

\section{A perspective on current realities and future possibilities}

\author{
Nicola Strong and Nicky Terblanche
}

Artificial intelligence (Al) is making inroads in the helping professions, including coaching. This conceptual paper considers the possible future of $\mathrm{Al}$ Coaching. We look at what is currently done in fields related to coaching and recommend chatbots as a promising technology for implementing $\mathrm{Al}$ Coaches. We describe what needs to be considered to implement chatbot Al Coaches from a practical, ethical and coaching best practice perspective. We conclude that the coaching community must get involved in understanding the potential of Al Coaching and help to chart the course for creating Al Coaches that not only adhere to coaching best-practices, but are also ethically sound.

There is a beep from my phone. I know what it is. My wellbeing coach, Wysa, wants to check in with me. Sometimes I am quietly reassured by this contact. Sometimes it is so the wrong moment. Wysa is an "emotionally intelligent« chatbot which responds to my text and emoji clues (Wysa). It is part of a wider research programme that uses a combination of evidence-based cognitive-behavioural therapy (CBT) techniques, natural language and mood tracking through my button choices to establish my current state of being. Our text-based conversation usually leads to appropriate messages of understanding with a guide on techniques to relax and build my skills in resilience. Wysa is a smartphone app available 24/7, patient, confident and occasionally witty.

As I am experimenting with Wysa, I cannot help but wonder if this is the future of coaching. Surely coaching (being truly present for another human) is a uniquely human skill. How much of this talk of artificial intelligence (AI), robots, chatbots and machine learning is hype and how much reality, and what role can it play both at work and in life coaching? 
The reality is that there are already over 500,000 chatbots (Harris \& Endsor, 2018) available to us, offering customer service, learning support, travel advice, companionship and even therapy. Some of these already play a role in the coaching space, but are they any good? In this article we will take a closer look at what it would take to build a chatbot coach (as an example of an AI coach), the ethical and moral considerations and where some current technologies are having an impact in the workplace today.

\section{Possible shapes of an Al coach}

Theoretically, an AI coach could appear in a number of forms, from a text-based conversational chatbot avatar that greets you in a virtual world to the physical presence of an "autonomous « virtual human (humanoid). For the purposes of this article we will focus on smartphone and web-based chatbots. A chatbot can be defined as a »computer program designed to simulate conversation with human users, especially over the Internet « (Oxford Dictionary, 2019). Bart Kamphorst helpfully clarifies coaching by a chatbot as an e-coaching system: »An e-coaching system is a set of computerized components that constitutes an artificial entity that can observe, reason about, learn from and predict a user's behaviors, in context and over time, and that engages proactively in an ongoing collaborative conversation with the user in order to aid planning and promote effective goal striving through the use of persuasive techniques" (Kamphorst, 2017). Whichever form it takes, it seems reasonable to expect that an AI coach would ultimately have to comply with existing definitions and required competencies of human coaches. Building on the premise of a human being present for another human, let us agree on a definition of humans coaching humans for the context of this article:

"Coaching is partnering with clients in a thought-provoking and creative process that inspires them to maximize their personal and professional potential.« (ICF, 2019a)

And as a skills guide, let us keep in mind what is expected of a human coach by referring to the eleven coach competencies set out by the International Coaching Federation (ICF) (cf. ICF, 2019b).

A. Setting the Foundation

1. Meeting Ethical Guidelines and Professional Standards

2. Establishing the Coaching Agreement 
B. Co-Creating the Relationship

3. Establishing Trust and Intimacy with the Client

4. Coaching Presence

C. Communicating Effectively

5. Active Listening

6. Powerful Questioning

7. Direct Communication

D. Facilitating Learning and Results

8. Creating Awareness

9. Designing Actions

10. Planning and Goal Setting

11. Managing Progress and Accountability

Are chatbots capable of complying with these requirements and what should be considered when creating a chatbot coach? We selected some examples of chatbots delivering coaching to illustrate the current activity and progress that has already been made.

\section{What a chatbot coach needs}

When creating a realistic chatbot coach, it is worth considering what type of data a chatbot coach requires to be an effective entity. If we draw from Heather Knight's (2010) research, they are:

- Human behaviour tracking

- Body language

- Behaviour systems

- Task-based interactions

- Ethics

- Gaze, expression: eye tracking face and mood recognition

- Personality: traits and psychological profiling

If we reference this list to look at some of the chatbots used as coaches and advisors in research or on the commercial market, we gain insight into their data needs.

Vicci is an autonomous entity built on a chatbot platform that coaches people on reaching their goals. This early stage prototype, created at the University of Stellenbosch Business School in South Africa, currently uses human behaviour tracking and task-based interactions when interacting with humans. Future plans include the use of traits and psychological profiling. 
Butterfly.ai is a leadership coach focusing on soft skills and assists an individual to »Become an exceptional leader with personalized guidance from [the] AI coach based on team member feedback «. When we refer to Knight's criteria, it collects and analyses employee data and listens to voice cues to give contextualised and personalised coaching.

Coach Otto was developed by Jeff Orkin and Dan Tomaschko (GiantOtter) and uses data mined from a data pool of real human conversations. The data is used to identify social norms and patterns of dialogue that can be used to create machines that could converse and cooperate with humans (MacMillan Bankson, 2017).

Coachbot is a team coach (designed by Saberr) where members of a team are invited to participate in a series of task-based interactions, such as individual surveys and tests that can be compared against a large library of data on team dynamics. With this preliminary fact finding, the human coach facilitates a discussion that builds on the diversity of thinking (Saberr, 2017).

Similar to Wysa, Youper is a chatbot used for promoting emotional health. Drawing on short conversations, mood tracking, Meyers-Briggs personality tests and task-based interactions, it provides tools, guides and ideas through text-based conversations (www.youper.ai).

Emoquo, is a »confidential coaching app that has aggregated advice from trained coaches and therapists to guide individuals through workplace stresses and anxieties. Whether it is a nightmare colleague or struggling to get through to your line manager, Emoquo confidentially coaches users through difficult conversations and problems they may face in the office« (The Guardian, 2018).

Maslo (Maslo.ai, 2019a) is an empathic diary. It analyses the voice journals of its user to identify smart patterns (Maslo.ai, 2019b) in their language in order to generate appropriate feedback. It also responds to the user with harmonies, sounds and swirling coloured shapes designed to support its human user.

From these selected examples we see that a wide variety of approaches are being used to promote the creation of chatbot coaches.

\section{Considerations for building a chatbot coach}

Coaching is all about the coachee, right? So, what would a human look for in a coaching chatbot? We drew up a list of what we would require when establishing a coaching relationship with a chatbot coach:

- Visually familiar

- Natural movement 
- Intelligent conversation indicating common sense

- Comprehension (how they sense us)

- Personality

- Security and safety of coachee's data

- Functionality and level of autonomy

- Ethical and moral grounding

- Empathy, intuition and imagination

- Presence

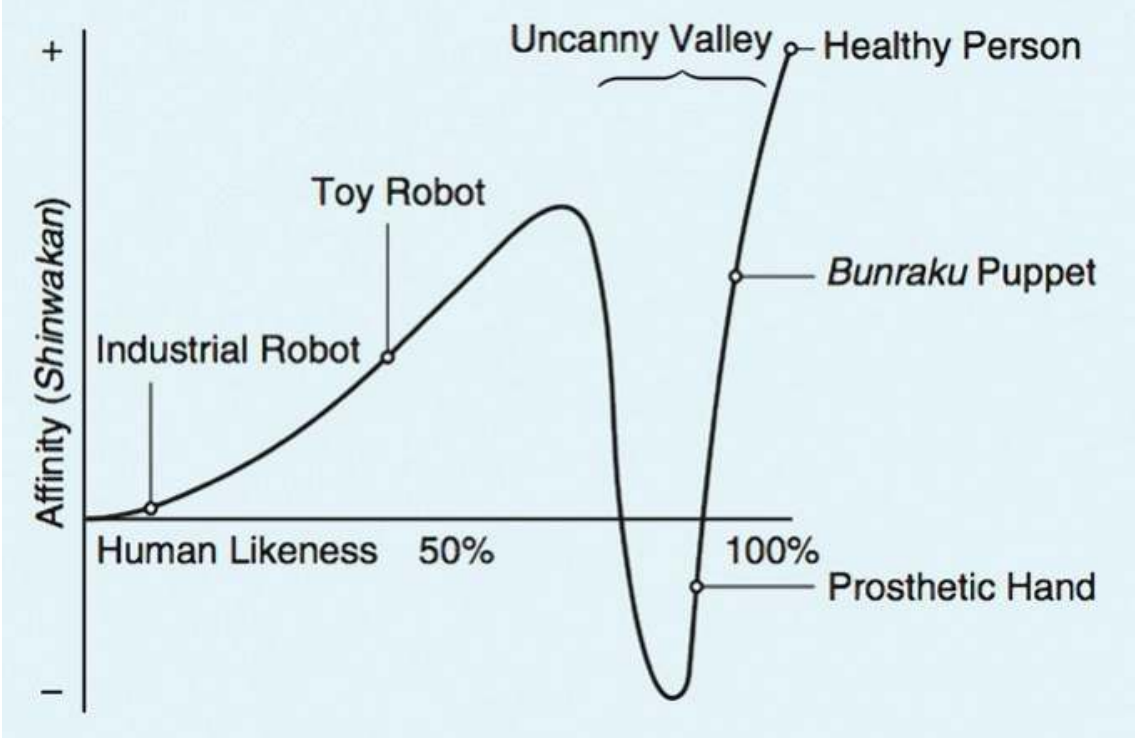

Figure 1: The Uncanny Valley Continuum (Mori, 2012; https://spectrum.ieee.org/automaton/ robotics/humanoids/the-uncanny-valley)

Attributing human characteristics, or anthropomorphising, a chatbot can have both a positive and a negative impact when it is assigned the role of an advisor or coach (Seeger, Pfeiffer, \& Heinzl, 2017). Does visual human familiarity gain a level of trust? Much work has been done since Mori's article in 1970 (Mori, 2012) in studying the uncanny valley where the visual impact of a device is measured against its perceived familiarity (see Figure 1). Looking at a scale from left to right, the traditional factory robot is unlikely to have any human likeness, therefore, a low familiarity score. As the machine becomes more humanlike, the familiarity increases. There is a point when this familiarity is so close to being human (but isn't) that it becomes uncomfortable and morbid. This negative reading forms the uncanny valley (Wikipedia, »Uncanny Valley«, 2019). 
Paradoxically, some humans find it easier to confide in an autonomous system without human characteristics - such as gathering witness statements and therapy bots. If humans already tend to assess and manage their level of openness with human coaches, is that very different to maintaining an awareness of a chatbot? The point is that chatbots, in any form, will need to give us the right level of visual clues to build our trust.

\section{Having a coaching conversation}

Let us get back to creating a coaching chatbot. The primary mode of communication of a chatbot is conversation (text or voice-based). There are three dimensions of a conversation that must be considered (Britz, 2016):

- closed vs open

- short vs long

- retrieval-based vs generative-based.

Open conversation refers to a large array of topics and contexts with the ability to switch context rapidly, e.g. from talking about the weather to switching to a discussion on climate change, whereas closed conversations are limited to a specific domain with limited complexity, e.g. ordering a pizza or asking for help on selecting a mortgage bond. Conversation duration refers to the amount of time a chatbot is able to hold a meaningful conversation. A chatbot that provides very specific information probably needs a conversation duration of one minute or two, whereas a more open-ended conversation could last several minutes or longer. Lastly, rule-based chatbots that use pre-defined scripts (retrievalbased) literally retrieve the next sentence from a finite list of options. A generative-based chatbot uses machine learning to generate conversations on the fly, based on what it deems appropriate for the context. At this point, we move closer to the concept of virtual humans and sentient beings.

One could, therefore, classify chatbots into two opposite camps: simple chatbots (closed, short, retrieval-based) and complex chatbots (open, long, generative-based). A quick look at some of the existing coaching chatbots such as Wysa, Youper, Woebot and Vicci reveal that they fall into the simple category of chatbots. Responses and questions are often repeated (retrieval-based) and the scope of conversation is limited (closed, short). At the complex end of the spectrum, the humanoid robot Sophia and the interviewing chatbot Intervyo are more self-aware, self-motivated and have an inner narrative (Burden \& SavinBaden, 2019). Coaching chatbots are not advanced enough as yet. 
For a chatbot to realistically mimic a human coach, we should strive to create more complex chatbots (open, long, generative-based). This borders on what is known as Artificial General Intelligence (AGI) - machines able to conceptualise and transfer knowledge on a par with or better than humans.

In the context of organisational and life coaching, Kamphorst (2017) provides us with some helpful criteria for building a realistic coaching chatbot:

1. Social ability: The coaching relationship (rapport) is considered by many the most important determinant of coaching efficacy. To build rapport, the chatbot must have the appearance of social awareness and the ability to »bond « with the client.

2. Trust and credibility: Trust has been shown to be an important predictor of a strong coaching relationship. The chatbot must therefore demonstrate expertise in order to come across as trustworthy and must be able to maintain trust.

3. Context-aware: The chatbot must be able to tailor a conversation based on the context of the client. One of the future versions of Vicci will use personality type as the cue for context-aware conversations.

4. Proactive: The coaching chatbot needs to invite conversation instead of simply responding to client input. This will help to stimulate reflection, a crucial element of successful coaching

5. Theoretical underpinning: It is important that the chatbot uses an underlying theoretical model, such as adult learning (e.g. Kolb) or psychology (e.g. CBT), to direct the coaching process. This is akin to a human coach whose coaching model should be underpinned by tried and tested theoretical models.

It appears that we have a relatively strong base and helpful guidelines to show the way forward in creating realistic coaching chatbots for workplace and life coaching, but what about the ethical aspects of such an endeavour?

\section{Ethics}

Mustafa Suleyman, CEO of DeepMind, tells us that "the study of the ethics, safety and societal impact of $\mathrm{AI}$ is going to become one of the most pressing areas of enquiry over the coming year " (Suleyman, 2018).

In the USA, the IEEE has released their guide on ethical AI (IEEE, 2019). In the UK, the House of Lords has set out key principles for the ethical design of AI. The Alan Turing Institute has launched a number of projects and, in partnership with The Nuffield Foundation, has created the Ada Lovelace Institute. 
The Leverhulme Centre for the Future of Intelligence, the Future of Life Institute, OpenAI, the Oxford Internet Institute, the Oxford Brookes University and the Royal Society for Arts, Manufactures and Commerce (2019) are all directing initiatives in addressing ethics and morality in AI. Closer to our focus on coaching is the work of the On-line Therapy Institute where they have set out an Ethical Framework for coaching through technology (Labardee, Nagel, \& Anthony, 2011). An impressive start, but much more needs to be done.

The ethics debate includes the knotty problems of liability and responsibility. Is it the chatbot designer, the commissioning organisation or the AI system itself that is accountable? This gets particularly complex in cases where chatbots that use Big Data and Machine Learning (generative-based) morph into something their inventors did not anticipate (Kamphorst, 2017).

Data itself presents a potential problem. Is the data used to train AI systems to be neutral and impartial, or are our current societal biases (e. g. racism, sexism) built-in? Care must be taken to use a representative data set when training a coaching chatbot and we need to define what »representative " means. Another issue with data is privacy. Who has access to the data and how is it used? Consider the saga of Cambridge Analytica. With that in mind, the team around Wysa and Vicci deliberately created their platform independently of the popular platforms such as Facebook and WhatsApp to ensure more control.

Kamphorst reminds us that there will be a question of fairness and autonomy. Who has access to the best e-coaching systems and how do we prevent chatbots being programmed to manipulate people?

Designers of conversational bots need to be bound by ethical guidelines. This is where the coaching community has an important role. Coaches need to join the ethical debate now. Regulations, human rights, legal and moral clarity all need attention, definition and boundaries in what is ultimately a very human condition - a human being present for another human being.

\section{Future}

And what about the future? While the holy grail of AI is Artificial General Intelligence (AGI) and the fascination to augment the human body persists, our relationship with technology is likely to get very personal indeed. Geoff Mulgan argues that, in future, AI enhancements will augment humans physically and mentally (Mulgan, 2018). Chips inserted into our bodies will enhance thought and skills (de Quetteville, 2019). It is highly likely that we will all have our own "wise« and trusted advisors/companions assigned to us at an early age. And we 
will be able to reference skills and learning from previous leaders, now dead, to guide us in our decisions (Burden \& Savin-Baden, 2019).

Burden and Savin-Baden suggest that our chatbot coach of the future will be able to take on a variety of visual, auditory or textual forms with the option to have embodiment within a virtual or physical world. They will draw on a huge data pool of our lives, including our decisions, actions, inactions, emotions, environments, health, skillsets and our augmented mind and body parts. They will be able to communicate "naturally« and hold their own mind and opinion on a topic. They will even be imaginative and witty at times. Imagine an AI coach with these characteristics! Even more reason to carefully consider the role of $\mathrm{AI}$ in our lives before our helpful virtual assistants and chatbot coaches glide towards demonstrating sentience and self-awareness (Burden \& Savin-Baden, 2019).

So how far are we from an AGI chatbot coach? Gartner's 2018 hype cycle on emerging technologies paints a dystopian picture as illustrated in Figure 2. AGI is firmly in the first (innovation) stage and is more than ten years away from the plateau of productivity. Some say we will not experience AGI in our lifetime.

\section{Hype Cycle for Emerging Technologies, 2018}

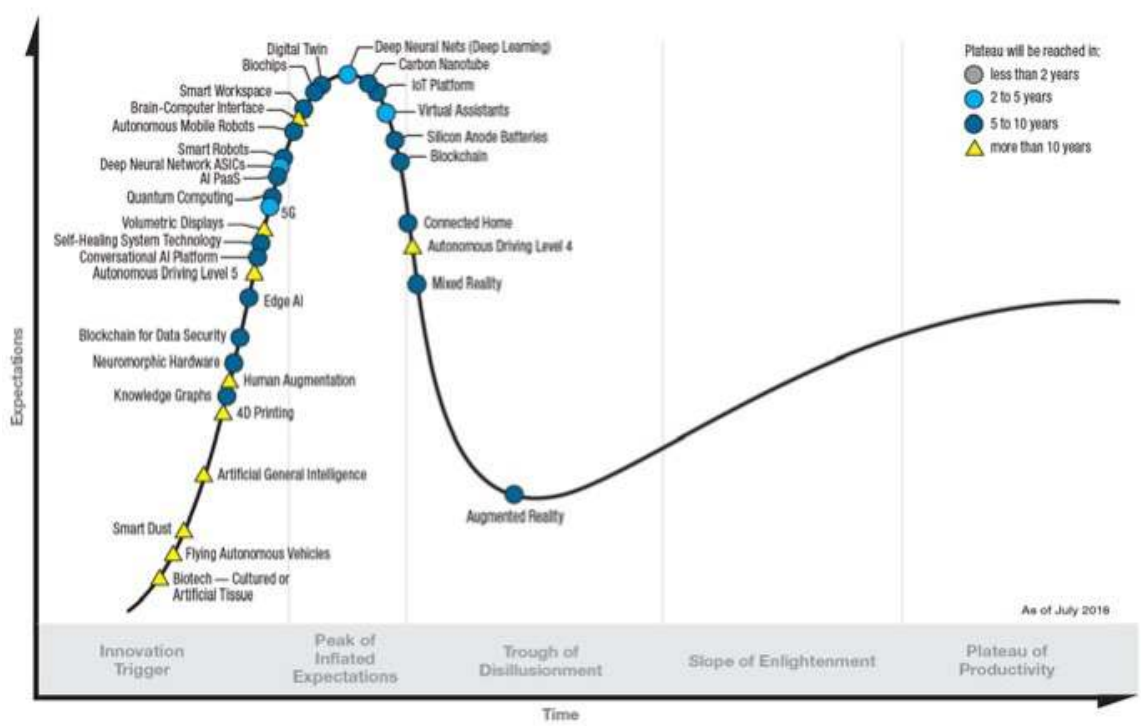

\section{gartner.com/SmarterWithGartner}

Source: Gartner (August 2018)

o 2018 Gartner, Inc. and/or its affiliates. All rights reserved

Figure 2: Hype Cycle for Emerging Technologies (Gartner, 2018) 
Nevertheless, we know that the number of chatbots is increasing exponentially in every aspect of our lives. Therefore, it is reasonable to assume there will be an increase in the impact these chatbots have on our learning, coaching and mentoring needs.

But how will this impact the coaching profession? Professor Clutterbuck suggests that experienced coaches will implement coach chatbots as tools to support rather than replace their work (Barber, 2018). An impressive example of a bot that can facilitate a series of team exercises on which the human coach can build is Saberr's CoachBot. It is those who are new to the profession of coaching and dependent on following theoretical models who are likely to be under threat.

\section{Conclusion}

In the context of a specific code of good coaching practice, this article looked at the criteria for a successful coaching relationship from both the human coachee and chatbot coach perspective. While coach bots are being created at an exponential rate, they have limited and defined capabilities. However, a quick look at some of the more well-known commercial bots tell us that there is progress in the technology every week.

If we consider building trust using familiarity, then we need to be aware of the uncanny valley and not alarm the coachee with an uncomfortable visual, audio or text representations of the chatbot. We found it helpful to understand more about using effective natural coaching conversations when creating coaching chatbots. We also revealed some of the biggest hurdles and pressing ethical issues for those developing chatbot coaches for workplace and life coaching.

As the evolution of AI draws on more data, computing power and innovation, it will be possible to mirror many more human abilities. At present, coaching chatbots can augment, not replace human coaches. This may change in the future. The wider adoption of advanced AI coaches in the workplace will lead to enormous technical, ethical and moral challenges. Is the coaching community informed and involved sufficiently to help guide this journey? Or will they find themselves unexpectedly sidelined? 


\section{References}

Barber, A. (2018). Coach versus bot: how do they compare? https://www.davidclutterbuckpartnership.com/coach-versus-bot-how-do-they-compare/ [20.2.2020].

Britz, D. (2016). Deep Learning for Chatbots. Part 1 - Introduction. www.wildml.com/2016/04/ deep-learning-for-chatbots-part-1-introduction/ [20.2.2020].

Burden, D., Savin-Baden, M. (2019). Virtual Humans. Today and Tomorrow. Boca Raton, FL: CRC Press.

Gartner (2018). Hype Cycle for Emerging Technologies. https://www.gartner.com/smarterwithgartner/ 5-trends-emerge-in-gartner-hype-cycle-for-emerging-technologies-2018/ [18.3.2020]

Harris, J., Endsor, M., (2018). The Business of Natural Language Computing. A Primer on Chatbots and Voicebots. CognitionX. https://www.edocr.com/v/wxnxzw1 m/techcelerate/The-Businessof-Natural-Language-Computing-by-Cogn [20.2.2020].

ICF (2019a). Code of Ethics. https://coachfederation.org/code-of-ethics [20.2.2020].

ICF (2019b). Core Competencies. https://coachfederation.org/core-competencies February 2019 [20.2.2020].

IEEE (2019). Ethics in Action. https://ethicsinaction.ieee.org/ [20.2.2020].

Kamphorst B. A. (2017). E-coaching systems: What they are, and what they aren't. Personal and Ubiquitous Computing, 21, 625-632. DOI: 10.1007/s00779-017-1020-6

Knight, H. (2010). Are robots the new vampires? https://www.slideshare.net/humanityplus/ knight-4671470 [20.2.2020].

Labardee, L., Nagel, D. M., Anthony, K. (2011). An Ethical Framework for the Use of Technology in Coaching. Therapeutic Innovations in Light of Technology, 1 (4), 20-28 https://www.onlinetherapyinstitute.com/ethical-framework-for-the-use-of-technology-in-coaching/ [20.2.2020].

MacMillan Bankson, A. (2017). Could an artificial intelligence-based coach help managers master difficult conversations? https://mitsloan.mit.edu/ideas-made-to-matter/could-artificial-intell ligence-based-coach-help-managers-master-difficult-conversations [20.2.2020].

Maslo.ai (2019a). Website. https://maslo.ai/ [20.2.2020].

Maslo.ai (2019b). Smart patterns. https://maslo.ai/about/ https://maslo.ai/about/ [20.2.2020].

Mori, M. (2012). The Uncanny Valley: The Original Essay. IEEE Robotics and Automation, 19 (2), 98-100.

Mulgan, G. (2018). The Future Integration of the Human and the Machine https://www.youtube. $\mathrm{com} /$ watch?v=HauyDk2kC8U [20.2.2020].

Oxford Dictionary (2019). "chatbot«. https://en.oxforddictionaries.com/definition/chatbot [20.2.2020].

The Guardian (2018). New app changing mental health in the workplace. https://www.emoquo.com/ news/emoquo-the-new-app-changing-mental-health-in-the-workplace/ [20.2.2020].

Quetteville, H. de (2019). This young man died in April. So how did our writer have a conversation with him last month? The Telegraph, 18 January 2019. https://www.telegraph.co.uk/techl nology/2019/01/18/will-digital-soul/ [20.2.2020].

Royal Society for the Encouragement of Arts, Manufactures and Commerce, RSA (2019). Forum for Ethical AI. https://www.thersa.org/action-and-research/rsa-projects/economy-enterprisemanufacturing-folder/forum-for-ethical-AI [20.2.2019].

Saberr (2017). A Digital Coach for Your Team. https://blog.saberr.com/an-ai-coach-for-your-teamd77d73aba388 [18.3.2020].

Seeger, A.-M., Pfeiffer, J., Heinzl, A. (2017). When Do We Need a Human? Anthropomorphic Design and Trustworthiness of Conversational Agents. SIGHCI 2017 Proceedings, 15. http:// aisel.aisnet.org/sighci2017/15 [20.2.2020]. 
Suleyman, M. (2018). DeepMind's Mustafa Suleyman: In 2018, AI will gain a moral compass. The ethics of artificial intelligence must be central to its development. Wired, 5 January 2018. https://www.wired.co.uk/article/mustafa-suleyman-deepmind-ai-morals-ethics [20.2.2020]. Wikipedia (2020). »Uncanny Valley«. https://en.wikipedia.org/wiki/Uncanny_valley [20.2.2020]. Wysa (2020). Introduction to Wysa. wysa.io [18.3.2020]

Youper.ai (2019). The science behind youper. https://www.youper.ai/science [20.2.2020]. 


\title{
Designing a fit-for-purpose coaching model to create sustained individual change during career transitions
}

\author{
Nicky Terblanche
}

Digital transformation and the Fourth Industrial Revolution have accelerated the rate of corporate change. In addition, personal ambition and a shortage of talented leaders mean that employees are promoted at a faster rate than before and expected to adapt to an ever-changing environment. Transitioning leaders often fail to perform as expected in their new roles, with harmful effects to the individual, their colleagues and the organisation. Transitioning leaders need to learn and adapt. Learning takes a number of forms, ranging from superficially adjusting thinking and behavioural patterns on the one end of the spectrum to challenging and adjusting deeply held worldviews and perspectives on the other. For sustained change, it would be preferable for transitioning leaders to undergo learning of the latter type. The question is whether coaching can be used to facilitate such deep, sustained learning and, if so, what should such a coaching approach look like?

The research shared in this article presents an innovative Transformative Transition Coaching (TTC) model that aims to address the issue of sustained change during career transitions. The TTC model combines transformative learning theory and transition coaching approaches into a novel method to facilitate deep, lasting changes in the world views and perspectives of transitioning leaders in order to help them succeed in their new roles. A two-phased research design, consisting of a foundation phase employing grounded theory principles and an application phase applying canonical action research, was used to create, refine and evolve the Transformative Transition Coaching model systematically.

The resultant TTC model consists of seven aspects (contextual, contractual, anticipatory, procedural, temporal, technical and efficacious) that must be taken into account when coaching transitioning leaders for sustained individual change. Findings suggest that the TTC model has the potential to facilitate lasting individual change, thus leading to successful career transitions. 


\section{The challenges of career transitions}

Transitions into senior corporate leadership positions are challenging (Freedman, 2011; Martin, 2015). Many transitions end in a sub-optimal state or even failure. Up to $46 \%$ of transitioning leaders underperform (Sutton, 2008) and as little as $16 \%$ transition successfully (Freedman, 2011). Apart from the negative emotional implications for the incumbent and their colleagues, estimates place senior leadership transition failure at several million dollars (Martin \& Gentry, 2011).

Several studies have investigated the reasons for career transition failure (Avolio \& Hannah, 2008; Bebb, 2009; Freedman, 2011; Martin, 2015; Watkins, 2003). These studies found that many transitioning leaders are unable to learn new skills (psychological, behavioural, cognitive, interpersonal) to adapt to the new roles. For transitioning leaders to succeed, it appears that they need help in unlearning unhelpful habits and acquiring new skills. Coaching offers the potential to facilitate this learning, but can it be done in a sustained manner?

\section{Transition coaching}

Organisations attempt to support transition leaders via various interventions such as leadership development programmes, mentoring and transition coaching (Freedman, 2011; Watkins, 2003). The jury is still out on the effectiveness of leadership development programmes (Avolio \& Hannah, 2008), but transition coaching seems to hold promise due to its individual, one-on-one nature (Kauffman \& Coutu, 2009; Witherspoon \& Cannon, 2004).

Transition coaching is defined as an individual coaching intervention aimed at supporting the transitioning leader by addressing issues that may prevent them from being effective in the new role (Witherspoon \& Cannon, 2004). Transition coaching is a relatively new field of research and practice, is in high demand (Bond \& Naughton, 2011) but not well researched or used adequately in practice (Terblanche, Albertyn, \& van Coller-Peter, 2017). Current approaches to transition coaching focus on aspects such as improved stakeholder management, more effective communication and developing new cognitive and social skills (Reynolds, 2011; Sutton, 2008; Witherspoon \& Cannon, 2004) but appear to stop short of creating sustained change on a more fundamental level (Bebb, 2009; Freedman, 2011). Transition coaching is typically started too late and used as a rescue mechanism rather than a pre-emptive support (Terblanche et al., 2017). This suggests that there could be scope for designing a transition coaching intervention with a more enduring effect. Understanding how adults learn may hold the key. 


\section{Transformative learning}

Transformative learning theory studies the mechanism of deep, permanent structural changes in adults as a result of a learning experience (Mezirow, 1994). Transformative learning is achieved through a process of critically questioning previously accepted values, beliefs, assumptions and perspectives (Cranton, 2005). The outcome of a transformative learning experience is a more open, inclusive and accommodating world view (Mezirow \& Associates, 2000).

Perspectives are a central concept in transformative learning theory and Mezirow distinguishes between a number of meaning perspectives: sociolinguistic (use of language and manner of social interaction); moral/ethical (what is right and wrong); epistemic (how knowledge is gathered); psychological (sense of self and others); philosophical (world views); health (what constitutes good health); political (influencing others); and aesthetic (interpretation of beauty) perspectives (Mezirow, 2008). A change in these meaning perspectives implies a change in how people filter their perception of the world. If, for example, a transitioning leader has an unhelpful sociolinguistic perspective, it implies they use inappropriate language or exhibit unsuitable social behaviour given the requirements of the new role. This may need to change in order to ensure success in the new role.

For the purpose of this research, Hoggan's (2016) three aspects of transformative learning were used to gauge whether someone has experienced transformative learning as a result of coaching. The three aspects are:

- Depth signifies the magnitude of the influence of the change on the person's life.

- Breadth refers to the number of contexts in which a change is manifested.

- Relative stability indicates that a change must be permanent to qualify as transformative.

The intersection between coaching and transformative learning seems to hold promise in helping transitioning leaders create sustained change in how they interpret and interact with the world.

\section{Methodology}

A two-phased research design was employed to create the transformative transition coaching (TTC) framework systematically. The first phase (foundation phase) used grounded theory principles (Charmaz, 2014) to create a draft coach- 
ing framework. The second phase (application phase) used canonical action research (Davison, Martinsons, \& Ou, 2012) to evolve the draft coaching framework into its final incarnation (for more information on this methodology, see Terblanche 2019).

\section{Foundation phase}

Grounded theory principles (theoretical sampling, constant analysis and comparison, initial and focused coding and memo writing) (Charmaz, 2014) were used to extract meaning from 16 interviews with various role players in career transitions. Participants included eight recently promoted senior managers who received coaching, five transition coaches as well as HR managers and oneline managers of a senior transitioning leader. The interviews questioned participants on their experience of career transitions and the role that coaching played. The themes and sub-themes identified were used to create a draft TTC framework which included aspects such as the need to contract explicitly for transition coaching, the timing of coaching and the coaching technique that seems to facilitate transition coaching. These aspects became part of the final TTC model.

\section{Application phase}

The draft TTC framework was used to coach six recently promoted senior corporate leaders using a canonical action research (CAR) approach (Davison et al., 2012). The draft framework was evolved and refined during each of the action research cycles. The appeal of a CAR approach is that it provides very clear guidelines, consisting of five principles and 44 associated evaluation criteria on how to scientifically practice action research.

Focal and instrumental theories, as prescribed by CAR were used to ensure rigour. A focal theory is the intellectual guide of the action research process, and for this research, Lane and Corrie's (2007) formulation framework (perspective, process, purpose) was used. Instrumental theories complement focal theories (Davison et al., 2012), and to this end, Mezirow's definition of perspectives (Mezirow, 1994) and Hoggan's evaluation of the level of transformative learning (Hoggan, 2016) were selected. This specific combination of focal and instrumental theories helped the CAR process to follow a coaching approach with a focus on transformative learning.

The action research cycle of plan $\rightarrow$ act $\rightarrow$ evaluate $\rightarrow$ reflect was followed using a nested approach consisting of macro and microcycles (Terblanche, 2014). A macrocycle consisted of six individual coaching sessions (microcycles), one per 
transitioning manager (denoted as »TM«). Data gathered during each micro and macrocycle included researcher and participant reflections, structured coaching feedback forms from TMs after each coaching session and post-coaching intervention interviews with TMs. At the end of each macrocycle, adjustments were made to the emerging TTC framework based on the evidence from that macrocycle. After five macrocycles, the final TTC framework emerged.

\section{Findings and discussion}

The TTC framework that emerged from this research consists of seven aspects, which guide a coach in coaching transitioning leaders in a manner that may facilitate transformative learning during a career transition.

\section{Contextual}

The context and focus of the coaching intervention must explicitly focus on supporting the transitioning leader by facilitating transformative learning. The foundation phase revealed that a focussed approach to coaching is needed to support the transitioning leaders and is in line with findings from Cox, Bachkirova and Clutterbuch (2014). This was confirmed during the application phase where TMs found the narrow focus of the coaching helpful.

\section{Contractual}

During the foundation phase, all the coaches interviewed reported going through a contracting phase involving an organisational representative. In the application phase, contracting was used with all six TMs and reaffirmed the importance for this aspect. Formal contracting has been shown to be a crucial aspect of coaching interventions (Passmore \& Fillery-Travis, 2011; Sparrow, 2007).

\section{Anticipatory}

Findings indicate that coaching goals relating to transition challenges must be agreed upon and recorded in collaboration with the organisation. Goal setting ensures the focus of the coaching remains within the context of the career transition. According to the participants from the foundation phase, coaching goals provided structure and helped coachees stay accountable, while findings from the application phase added to the understanding of how to apply the set goal 
by emphasising the importance of prioritising goals. This is in line with Passmore and Fillery-Travis (2011).

\section{Procedural}

TMs move through five stages when exposed to the TTC model:

- Stage 1 - Initiate: Define the context for the coaching and identify the most pressing challenges faced by the transitioning leader.

- Stage 2 - Understand: Analyse the current perspectives held by the transitioning leader on the following: sociolinguistic, moral/ethical, epistemic, philosophical, psychological, health, political, aesthetic.

- Stage 3 - Identity and design: Identify the most problematic perspective from Stage 2. Reflect on the origins of this perspective and its negative effects. Conceptualise the desired new perspective and design a behavioural experiment to change the problematic perspective.

- Stage 4-Reflect and redesign: Reflect on the progress with transforming the problematic perspective using Hoggan's transformative learning criteria (Hoggan, 2016) and design a new behavioural experiment to deepen the transformative process.

- Stage 5 - Complete: This state is reached when the transitioning leader shows an acceptable level of perspective transformation according to Hoggan's criteria. A strategy is defined to secure the transformation, put stretch goals in place and decide to terminate the coaching or select a new problematic perspective to transform.

These five TTC stages are not singularly linked to individual coaching sessions. A coachee could remain in one stage for more than one coaching session, revisit a stage or cover multiple stages in a single coaching session.

The procedural aspect of the TTC framework explicitly includes Mezirow's perspectives (Mezirow, 1994) and Hoggan's (2016) criteria for transformative learning in the coaching model. This inclusion operationalises transformative learning in transition coaching and answers the call for more research into the links between coaching and transformative learning theory (Cox et al., 2014; Theeboom, Beersma \& van Vianen, 2013).

\section{Temporal}

The temporal aspect of the TTC framework encapsulates the timing elements of the intervention. Participants in the foundation phase reported interventions 
ranging between six and ten sessions only over a period of less than a year. It was felt that this was inadequate. Participants suggested that coaching should start before the promotion takes effect (two to three sessions a few weeks apart), followed by frequent coaching sessions (every two to four weeks) for the first six months after the promotion and less frequent coaching (every one to three months) for at least another one to two years.

Research has shown that the robustness of the coaching results increases with the number of coaching sessions (Theeboom et al., 2013), and in transformative learning, deeper levels of learning occur when adequate time is available for critical reflection and active experimentation (Mezirow, 1994).

\section{Technical}

During the foundation phase, 13 coaching tools and techniques used to facilitate deep, permanent changes were identified. Five were used substantially more than the rest: questioning, reflection, active experimentation, using frameworks and theory (about career transitions and transformative learning), as well as challenging views and assumptions. Using these techniques may therefore accelerate transformative learning.

\section{Efficacious}

The efficacious aspect of the TTC model was achieved by using Hoggan's (2016) three criteria. Hoggan's three criteria were found to be useful for evaluating the level of transformation and, hence, the success of the transition coaching intervention. Of the six TMs who were coached using the TTC model, four satisfied Hoggan's criteria for transformative learning.

\section{Contributions}

On a scholarly level, the association between coaching and one of its fundamental underpinning theories (adult learning) is strengthened through the operationalisation of transformative learning in the coaching process. The understanding of coaching practice is enhanced by the identification of coaching techniques that lead to transformative learning. On a practical level, a new empirically researched coaching framework is presented that could be used by coaches, purchasers of coaching services and coach training providers in relation to transition coaching interventions. 


\section{Conclusion}

Many who attempt a senior leadership transition fail. This research showed that it is possible to design a fit-for-purpose transition coaching model that incorporates transformative learning theory to facilitate deep, permanent shifts in people to help equip them to succeed in their new role.

\section{References}

Avolio, B. J., Hannah, S. T. (2008). Developmental Readiness: Accelerating Leader Development. Consulting Psychology Journal: Practice and Research, 60 (4), 331-347.

Bebb, S. (2009). The structure of role transition: A phenomenological study of successful executives from five countries. International Journal of Leadership Studies, 4 (2), 223-243.

Bond, A., Naughton, N. (2011). The role of coaching in managing leadership transitions. International Coaching Psychology Review, 6 (2), 165-179.

Charmaz, K. (2014). Constructing grounded theory. London: Sage.

Cox, E., Bachkirova, T., Clutterbuck, D. (2014). Theoretical traditions and coaching genres: Mapping the territory. Advances in Developing Human Resources, 16 (2), 139-160.

Cranton, P. (2005). Transformative Learning. In L. M. English (Ed.), International encyclopedia of adult education (pp. 630-637). New York: Palgrave Macmillan.

Davison, R., Martinsons, M., Ou, C. (2012). The role of theory in Canonical Action Research. MIS Quarterly, 36 (3), 763-786.

Freedman, A. M. (2011). Some Implications of Validation of the Leadership Pipeline Concept: Guidelines for Assisting Managers-in-Transition. The Psychologist-Manager Journal, 14 (2), 140-159.

Hoggan, C. (2016). Transformative Learning as a Metatheory: Definition, Criteria, and Typology. Adult Education Quarterly, 66 (1), 57-75.

Kauffman, C., Coutu, D. (2009). The realities of executive coaching. Harvard Business Review, $87(1), 6-7$.

Martin, J. F. (2015). Ascending to the C-suite. New York: McKinsey \& Company.

Martin, J., Gentry, W. (2011). Derailment Signs across Generations: More in Common than Expected. The Psychologist-Manager Journal, 14 (3), 177-195.

Mezirow, J. (1994). Understanding transformation theory. Adult Education Quarterly, 44 (4), 222-232.

Mezirow, J., Associates (2000). Learning as transformation: Critical perspectives on a theory in progress. San Francisco, CA: Jossey-Bass.

Mezirow, J. (2008). An overview on transformative learning. In J. Crowther, P. Sutherland (Eds.), Lifelong learning: Concepts and contexts (pp. 24-38). Abingdon, Oxon: Routledge.

Passmore, J., Fillery-Travis, A. (2011). A critical review of executive coaching research: A decade of progress and what's to come. Coaching: An International Journal of Theory, Research and Practice, 4 (2), 70-88.

Reynolds, G. (2011). Exploring the meaning of coaching for newly appointed senior leaders in their first twelve to eighteen months in role. International Journal of Evidence Based Coaching and Mentoring, (Special Issue 5), 39-53.

Sparrow, S. (2007). Leading the leaders. Training \& Coaching Today, (July/August), 22-23.

Sutton, J. (2008). Coaching leadership transitions. In J. L. Noel, D. L. Dotlich (Eds.), The 2008 Pfeiffer Annual Leadership Development (pp. 199-207). Hoboken, NJ: Wiley \& Sons. 
Terblanche, N. (2014). Knowledge sharing in the organizational context: Using Social Network Analysis as a coaching tool. International Journal of Evidence Based Coaching and Mentoring, $12(2), 146-164$.

Terblanche, N. (2019). The coaching model derivation process: combining grounded theory and canonical action research for developing coaching models. Coaching: An International Journal of Theory, Research and Practice, 13 (1), 1-16.

Terblanche, N., Albertyn, R., Coller-Peter, S. van (2017). Designing a coaching intervention to support leaders promoted into senior positions. SA Journal of Human Resource Management/ SA Tydskrif vir Menslikehulpbronbestuur, 15, a842.

Theeboom, T., Beersma, B., Vianen, A. van (2013). Does coaching work? A meta-analysis on the effects of coaching on individual level outcomes in an organizational context. The Journal of Positive Psychology, 9 (1), 1-18.

Watkins, M. D. (2003). The First 90 Days: Critical Success Strategies for New Leaders at All Levels. Boston, MA: Harvard Business School Press.

Witherspoon, R., Cannon, M. (2004). Coaching leaders in transition. In A. Buono (Ed.), Creative consulting: Innovative perspectives on Management Consulting (pp. 201-227). Information Age Publishing. 


\title{
Motto-Ziele im digitalen Wandel
}

\section{Persönliche Metaphern als emotionale Ressource im Coaching}

Thomas H. Dyllick

Attitude is a little thing that makes a big difference.

Winston Churchill

Zuerst die innere Haltung, dann die äußere Form!

Konfuzius

\begin{abstract}
Motto-Ziele sind ein vergleichsweise neuer Zieltyp, der im Coaching und Training eingesetzt wird und der auf die innere Haltung gerichtet ist. Im Kern sind Motto-Ziele individualisierte Metaphern, die durch einen spezifischen, persönlichen Bildungsprozess zustande kommen. Durch die metaphorische Sprache sind sie besonders geeignet, die innere Haltung von Personen zu beeinflussen. Die bisherige Forschung zeigt die Effektivität von Motto-Zielen, die gemeinsam mit einem Coach oder Trainer gebildet werden. Im vorliegenden Beitrag wird eine digitalisierte Motto-Ziel-Intervention vorgestellt, die es ermöglicht, Motto-Ziele in kurzer Zeit und in Einzelarbeit mithilfe eines Computers oder Tablets zu bilden. Es werden vier randomisiert kontrollierte Studien vorgestellt, welche die Wirksamkeit der digitalisierten Motto-ZielIntervention im Umgang mit unangenehmen Aufgaben untersuchten. Es hat sich dabei gezeigt, dass die digitalisierte Motto-Ziel-Intervention zu einer adaptiveren und gesünderen inneren Haltung beim Umgang mit unangenehmen Aufgaben führt. Der Beitrag schließt mit einer Zusammenfassung und einem Ausblick auf Anwendungsmöglichkeiten.
\end{abstract}

Stellen Sie sich vor, Sie hätten eine Klientin, die mit der Haltung arbeitet: »Was du heute kannst besorgen, das verschiebe nicht auf morgen.« Ein anderer Klient arbeitet mit der Haltung: "Nach mir die Sintflut. « ${ }^{1}$ Welche Person hat vermutlich Probleme in ihrem Team? Und warum?

1 Beispiele aus Adlmaier-Herbst, Storch, Storch \& Breiter (2018). 
Intuitiv ist uns klar, dass unterschiedliche Haltungen sich in ganz unterschiedlichen Arbeitsweisen niederschlagen. Auch die Forschung hat sich mit den Effekten von inneren Haltungen beschäftigt. Wissenschaftlich wird eine innere Haltung definiert als Fokus oder Geisteshaltung, die ein Individuum auf bestimmte Assoziationen und Erwartungen ausrichtet (Crum \& Zuckerman, 2017). Empirische Studien zeigen die Wichtigkeit der inneren Haltung für Motivation und Leistung (Dweck, 2016; Paunesku et al., 2015; Yeager et al., 2014), aber auch für die Gesundheit von Individuen (Crum \& Zuckerman, 2017; Jamieson, Crum, Goyer, Marotta \& Akinola, 2018). So ließ sich beispielsweise zeigen, dass die gleiche körperliche Tätigkeit je nach innerer Haltung unterschiedliche Auswirkungen auf die Gesundheit hat (Crum \& Langer, 2007); es braucht also auch eine passende innere Haltung, um von einer körperlichen Tätigkeit auch profitieren zu können. Des Weiteren konnte gezeigt werden, dass erlebter Stress Nachteile wie auch Vorteile mit sich bringen kann - wiederum in Abhängigkeit von der inneren Haltung (Crum, Salovey \& Achor, 2013; Jamieson et al., 2018). Die innere Haltung einer Person scheint also enorme Auswirkungen zu haben. Aber wie lässt sie sich verändern? Eine Möglichkeit im Coaching und Training ist die Arbeit mit Zielen. Ein Zieltyp, der speziell entwickelt wurde, um die innere Haltung zu adressieren, sind Motto-Ziele (Storch \& Krause, 2017).

Im Folgenden wird zunächst umrissen, was wir uns unter Motto-Zielen vorzustellen haben, anschließend wird Forschung zur Digitalisierung einer MottoZiel-Intervention präsentiert.

\section{Motto-Ziele}

Motto-Ziele sind persönlich gebildete Metaphern, die eine gewünschte innere Haltung beschreiben (z. B. »Mit Bärenruhe gehe ich meinen Weg«). Sie stellen das Verhalten von Personen unter ein Motto, das sich auf die Art und Weise der Zielverfolgung bezieht (Storch \& Krause, 2017). Durch die metaphorische Sprache und die spezifischen Charakteristika des Bildungsprozesses sind MottoZiele besonders effektiv darin, Emotionen auszulösen und zu regulieren (Dyllick, 2018; Storch \& Krause, 2017). Dies hat zur Folge, dass die formulierte innere Haltung von Individuen sogleich "gefühlt« und erlebt werden kann (Storch \& Krause, 2017).

Motto-Ziele sind eine zentrale Technik des Zürcher Ressourcen Modells (ZRM; vgl. Storch \& Krause, 2017). Das ZRM ist ein Selbstmanagementtraining, das sowohl im Coaching als auch als Gruppentraining Anwendung findet. Das ZRM wird fortwährend auf seine Wirksamkeit in verschiedenen Bereichen 
untersucht; es zeigt positive Effekte vor allem in den Bereichen der Emotionsregulation und der Selbstregulation (Steurer-Stey et al., 2015; Storch, Gaab, Küttel, Stüssi \& Fend, 2007; Storch, Keller, Weber, Spindler \& Milos, 2011; Storch \& Olbrich, 2011). Zum Beispiel fanden Storch et al. (2007), dass Personen, die im Rahmen des ganzen Trainings ein Motto-Ziel bildeten, während einer stressreichen Aufgabe niedrigere Cortisolwerte aufwiesen als eine Kontrollgruppe ohne Motto-Ziele.

Auch unabhängig vom Gesamttraining wurden Motto-Ziele bereits untersucht. So konnte Weber (2013) die Effekte einer Motto-Ziel-Gruppenintervention zeigen. Sie fand eine verbesserte Fähigkeit zur Emotionsregulation und erhöhte positive Emotionen für Teilnehmende der Motto-Ziel-Intervention, verglichen mit zwei alternativen Trainingsgruppen.

\section{Digitalisierung einer Motto-Ziele-Intervention}

Die Digitalisierung von Motto-Ziel-Interventionen sollte unter anderem ermöglichen, dass ein Motto-Ziel mithilfe eines Computers oder Tablets, unabhängig von Trainerin oder Coach, in Einzelarbeit gebildet werden kann. Um eine möglichst kurze digitale Version der Intervention zu erhalten, wurden in einem ersten Schritt die zentralen Wirkbestandteile analysiert (vgl. Dyllick, 2018). Der Motto-Ziel-Bildungsprozess kann im Kern als individuell gebildete Metapher konzeptualisiert werden (a.a.O.). Die digitalisierte Motto-Ziel-Intervention enthält nur die Kernschritte, um eine individuelle Metapher zu bilden, bewahrt dabei aber die spezifischen Charakteristika des Bildungsprozesses von MottoZielen.

Die digitalisierte Motto-Ziel-Intervention besteht aus vier Schritten. Im ersten Schritt wählen Personen ein Thema, zu dem sie gerne eine andere innere Haltung hätten (z. B. eine Aufgabe, ein Ziel oder eine Pflicht). ${ }^{2}$ Im zweiten Schritt werden Bilder präsentiert, von denen Teilnehmende sich eines auswählen sollen, das ausschließlich positive Emotionen auslöst und so beim gewählten Thema als Ressource dienen kann. Im dritten Schritt werden die Teilnehmenden angeleitet, positive Assoziationen zum gewählten Bild zu finden. Im vierten Schritt sollen sie mit den gewählten Assoziationen ein Motto-Ziel bilden. Ein Beispiel: In der später beschriebenen Studie von Dyllick (2018) wählte eine Teilnehmerin die unangenehme Aufgabe »Lernen für die Prüfung« als Thema. Im zweiten

2 Es gibt auch die Möglichkeit, kein spezifisches Thema auszuwählen und ein generelles MottoZiel zu bilden (vgl. Storch \& Krause, 2017). 
Schritt wählte sie das Bild eines Wolfs, da es positive Emotionen bei ihr auslöste. Im dritten Schritt lösten die Assoziationen »instinktsicher«, »hat das Ziel im Visier " und »vertraut auf sein Wissen " positive Emotionen bei ihr aus. Im vierten Schritt formulierte sie die gewünschte innere Haltung mit den Assoziationen »Wie der Wolf habe ich mein Ziel im Visier, vertraue auf mein Wissen und meine Instinkte«.

Die Bilder, die im zweiten Schritt der digitalisierten Version präsentiert werden, stammen aus der ZRM-Bildkartei von Krause und Storch (2017), die für das Gesamttraining entwickelt wurde und im Gruppentraining sowie im Coaching eingesetzt wird (Storch \& Krause, 2017). Die Bilder zeigen eine Vielzahl von Inhalten, zum Beispiel Tiere, Pflanzen, Landschaften und Menschen in angenehmen Situationen. Die Assoziationen im dritten Schritt werden im Training oder im Coaching in einem strukturierten Brainstorming-Verfahren gebildet. Damit Motto-Ziele in der digitalisierten Version in Einzelarbeit gebildet werden können, wurde von erfahrenen Trainern zu jedem Bild eine Liste mit Assoziationen erstellt.

Die digitalisierte Motto-Ziel-Intervention ermöglicht das Bilden eines BasisMotto-Ziels in rund fünfzehn Minuten Einzelarbeit. Von Basis-Motto-Ziel sprechen wir deshalb, weil bei der Entwicklung der digitalisierten Version der Motto-Ziel-Bildungsprozess im Vergleich zum Training oder Coaching stark gekürzt wurde, sodass nur die Kernelemente erhalten blieben (vgl. Dyllick, 2018). Im Training oder Coaching findet zum Beispiel eine angeleitete Reflexion über die dem Motto-Ziel zugrunde liegenden Bedürfnisse statt, und das Motto-Ziel wird mit Unterstützung der Trainerin oder des Coaches in mehreren Feedbackschleifen weiter optimiert (Storch \& Krause, 2017).

Um die Frage zu beantworten, ob die digitalisierte Motto-Ziel-Intervention die innere Haltung von Personen zu einer unangenehmen Aufgabe verändern kann, führte Dyllick (2018) vier randomisierte kontrollierte Studien mit insgesamt 391 Teilnehmenden durch. Um zu überprüfen, ob die Intervention $\mathrm{zu}$ einer adaptiven und gesunden inneren Haltung führt, wurden positiver Affekt, Vitalität und Autonomieerleben der Teilnehmenden gemessen. Vitalität ist ein subjektives Gefühl von Lebendigkeit und Energie (Ryan \& Frederick, 1997), und die Forschung sieht sie als wichtigen Indikator für Motivation und Gesundheit (Ryan \& Deci, 2008). So konnten Studien zeigen, dass Menschen, wenn sie sich vital fühlen, aktiver und produktiver sind, besser mit Stress umgehen und eine größere mentale Gesundheit berichten (Ryan \& Frederick, 1997; Kasser \& Ryan, 1999; Penninx et al., 2000). Autonomie wird als psychologisches Grundbedürfnis gesehen (Deci \& Ryan, 2000), und die Forschung zeigt, dass Autonomieerleben eine Grundvoraussetzung für subjektives Wohl- 
befinden ist (vgl. Ryan, Huta \& Deci, 2008). Darüber hinaus hängt Autonomieerleben mit intrinsischer Motivation, größerer Kreativität und niedrigerem Stresserleben zusammen (Dysvik, Kuvaas \& Gagné, 2013; Gagné \& Deci, 2005; Roth, Assor, Kanat-Maymon \& Kaplan, 2007; Weinstein \& Ryan, 2011). Auch positive Emotionen sind mit vielen Vorteilen für Individuen verbunden (vgl. Lyubomirsky, King \& Diener, 2005). Sie erhöhen zum Beispiel die Resilienz; sie führen auch zu rascherer kardiovaskulärer Erholung nach einem stressigen Ereignis (Tugade \& Fredrickson, 2004), schnellerer Erholung nach negativen Emotionen (Fredrickson \& Levenson, 1998; Fredrickson, Mancuso, Branigan $\&$ Tugade, 2000) und wirken als Puffer gegen die Entwicklung von depressiven Symptomen (Fredrickson, Tugade, Waugh \& Larkin, 2003).

In einer ersten Studie konnte Dyllick (2018) zeigen, dass die digitalisierte Motto-Ziel-Intervention im Vergleich zu einer Kontrollgruppe, die eine Ablenkungsaufgabe durchführte, zu höherem positivem Affekt, höherer Vitalität und mehr Autonomieerleben führte (Dyllick, 2018; Studie 1). Ein potenzieller Kritikpunkt bei dieser Studie ist, dass die Effekte der Motto-Ziel-Intervention auch auf generelle Erwartungseffekte oder eine Demand-Charakteristik zurückgeführt werden könnten. Um diese Alternativerklärungen auszuschließen, wurde in einer zweiten Studie die digitalisierte Intervention mit einer PlaceboIntervention verglichen. Es zeigte sich, dass die digitalisierte Intervention der Placebo-Intervention überlegen war und zu höherer Vitalität, positivem Affekt und verstärktem Autonomieerleben führte (Dyllick, 2018; Studie 2). In einer dritten Studie wurde die digitalisierte Motto-Ziel-Intervention noch genauer unter die Lupe genommen. Grob lassen sich zwei Teile unterscheiden: Wahl eines positiven Bildes und Bildung des Motto-Ziels mit den gewählten Assoziationen. Es wäre theoretisch vorstellbar, dass die Effekte der Intervention auf die Wahl eines positiven Bildes zurückzuführen sind. Die Forschung zeigt die Effekte von Bildern auf Emotionen (z. B. Lang, Greenwald, Bradley \& Hamm, 1993); in psychologischen Studien werden Bilder oft verwendet, um Emotionen auszulösen (für einen Überblick vgl. Quigley, Lindquist \& Feldman Barrett, 2014). Deshalb wurde in der dritten Studie die gesamte Motto-Ziel-Intervention mit dem ersten Teil der Intervention verglichen: der Wahl eines positiven Bildes als Ressource. In dieser Studie wurde gefunden, dass beide Interventionen effektiv darin waren, positiven Affekt zu erhöhen. Die Motto-Ziel-Intervention war allerdings noch effektiver darin, die Vitalität zu steigern (Dyllick, 2018; Studie 3). Zusätzliche Analysen zeigten einen weiteren wichtigen Unterschied zwischen den Bedingungen: Nur Personen in der Motto-Ziel-Bedingung berichteten eine Änderung der Einstellung gegenüber der unangenehmen Aufgabe (Dyllick, 2018; Studie 3). Eine innere Haltung als Motto-Ziel zu formulieren, scheint also 
zusätzlichen Nutzen zu bringen. Weitere Analysen zeigten, dass dies besonders für Personen mit niedrigen Vitalitäts-Eingangswerten gilt. Solch niedrige Werte sind ein Indikator für wenig Energie und Motivation (Ryan \& Deci, 2008); sie hängen damit zusammen, dass Personen ihre Stärken nicht nutzen können (Dubreuil, Forest \& Courcy, 2014). Darin liegt nun eine mögliche Erklärung für den Befund, dass Personen mit niedrigen Vitalitäts-Eingangswerten einer Intervention bedürfen. Bei dieser Gruppe scheint die Wahl eines positiven Bildes nicht zu genügen; es braucht die weiteren Schritte; die innere Haltung muss in Form eines Motto-Ziels formuliert werden, um einen Effekt zu erzielen.

Zusammengefasst, zeigen die Studien von Dyllick (2018), dass Motto-Ziele, die mit der digitalisierten Intervention gebildet werden, mit einer adaptiven und gesunden inneren Haltung zusammenhängen.

Auch zur Frage, wie lange die Effekte anhalten, gibt es erste Anhaltspunkte. Bezogen auf Langzeiteffekte von Motto-Zielen, präzisieren Storch und Krause (2017), dass die Bildung eines Motto-Ziels - egal, ob im Training, Coaching oder in digitalisierter Form - nicht automatisch zu einer langfristigen Einstellungsänderung führt, sondern dass Motto-Ziele in den Alltag von Individuen integriert werden müssen, um langfristig wirksam zu sein. Dies kann zum Beispiel dadurch geschehen, dass das Motto-Ziel im Alltag immer wieder bewusst gemacht wird, indem man es etwa auf einen Zettel schreibt und diesen Zettel an prominenter Stelle anbringt (für weitere Techniken vgl. Storch \& Krause, 2017). Dyllick (2018, Studie 4) führte ein kontrolliertes Feldexperiment über mehrere Messzeitpunkte durch, bei dem Studierende beim Lernen auf eine unangenehme Prüfung begleitet wurden. Wie in Studie 3 zeigte sich, dass die digitalisierte Motto-Ziel-Intervention unterschiedlich effektiv war, je nachdem, wie es den Teilnehmenden vor der Intervention ging. Besonders Teilnehmende mit niedrigen Vitalitäts-Eingangswerten profitierten von der Intervention und berichteten höhere positive Emotionen, Vitalität und Autonomie während des Lernens im Vergleich zu einer Kontrollgruppe. Das gleiche Ergebnismuster wurde auch einige Zeit nach der Intervention in der letzten Woche vor der Prüfung gefunden, allerdings nur für Teilnehmende, die sich an die Anweisung gehalten hatten, das Motto-Ziel auf einen Zettel zu schreiben und täglich anzusehen (Dyllick, 2018, Studie 4). Dieser Befund unterstreicht die Wichtigkeit weiterer Techniken nach der Motto-Ziel-Bildung, um die langfristige Wirksamkeit sicherzustellen. 


\section{Fazit}

Die digitalisierte Motto-Ziel-Intervention ist aus Forschersicht interessant, weil sie den Vorteil bietet, dass die Effekte von Motto-Zielen unabhängig vom Gruppenkontext und der Anwesenheit einer Trainerin oder eines Coaches untersucht werden können. Somit können spezifische Effekte von Motto-Zielen unabhängig von sogenannten common factors wie Effekten der Persönlichkeit des Trainers oder der Coachin und des Gruppenkontexts untersucht werden (zur Differenzierung von spezifischen Effekten und common factors vgl. Lambert \& Barley, 2001). Die berichteten Befunde von Dyllick (2018) zeigen die spezifischen Effekte von Motto-Zielen, die mit einer digitalisierten Intervention gebildet wurden. Sie zeigen auch, dass Motto-Ziele effektiv darin sind, die innere Haltung von Personen zu verändern. Durch die Variation der Kontrollgruppen wurden mögliche Alternativerklärungen ausgeschlossen. Da der Prozess zur Bildung von Motto-Zielen für die digitalisierte Version stark verkürzt wurde, würden Motto-Ziele, die im Coaching oder im Training gebildet werden, vermutlich noch größere Effekte erzielen.

Auch aus Anwendersicht ist die digitalisierte Intervention interessant und bietet reichhaltiges Potenzial. Die digitalisierte Motto-Ziel-Intervention steht kostenlos unter dem Namen ZRM ${ }^{\oplus}$-Onlinetool im Internet zur Verfügung (Link am Ende des Beitrags). Ein ${ }^{\star}$ K Klient ${ }^{*}$ in kann zum Beispiel im Coaching ein Motto-Ziel mit dem Onlinetool erstellen, das dann zur Coachingsitzung mitgebracht wird. In der Sitzung kann das Motto-Ziel optimiert werden (vgl. Storch \& Krause, 2017), und vor allem kann die Übertragung in den Alltag im Coaching sichergestellt werden (a. a. O.).

Des Weiteren stärkt die Möglichkeit, Motto-Ziele selbstständig zu bilden, die Unabhängigkeit der Klientin. Insbesondere für Personen, die mit dem ZRM und mit Motto-Zielen bereits vertraut sind, bietet das Onlinetool eine gute Möglichkeit, den ZRM-Prozess eigenständig zu durchlaufen.

Einschränkend ist zu erwähnen, dass das Onlinetool vermutlich nicht für alle Personengruppen geeignet ist. So setzt der verkürzte Prozess der MottoZiel-Bildung eine gewisse Bereitschaft voraus, sich auf die Technik einzulassen. In den Daten von Dyllick (2018) kann man sehen, dass für 8 bis 15 Prozent der Teilnehmenden die digitalisierte Motto-Ziel-Intervention keinen Effekt erzielt. Diese Personengruppe würde vermutlich individuelle Unterstützung durch einen Coach oder Trainer benötigen.

Zusammenfassend bieten Motto-Ziele eine Möglichkeit, die innere Haltung von Personen zu verändern. Die vorgestellten Studien zeigen, dass Motto-Ziele, die mit einer digitalisierten Intervention gebildet werden, das subjektive Erleben 
von Personen verändern. Die Ergebnisse dieser Studien bieten eine spannende Grundlage für weitere Forschung sowie für die empirisch fundierte Anwendung von Motto-Zielen.

\section{Link zum ZRM ${ }^{\circledast}$ Onlinetool: www.ismz.ch/ZRM/OnlineTool.html}

\section{Literatur}

Adlmaier-Herbst, G., Storch, M., Storch, J., Breiter, A. (2018). Change-Management - so klappt's! Die vier ZRM-Innovationen für den erfolgreichen Wandel. Göttingen: Hogrefe.

Crum, A. J., Langer, E. J. (2007). Mind-Set Matters. Exercise and the Placebo Effect. Psychological Science, 18 (2), 165-171. DOI: 10.1111/j.1467-9280.2007.01867.x

Crum, A. J., Salovey, P., Achor, S. (2013). Rethinking stress: The role of mindsets in determining the stress response. Journal of Personality and Social Psychology, 104 (4), 716-733. DOI: 10.1037/a0031201

Crum, A. J., Zuckerman, B. (2017). Changing mindsets to enhance treatment effectiveness. Jama, 317 (20), 2063-2064. DOI: 10.1001/jama.2017.4545

Deci, E. L., Ryan, R. M. (2000). The »what« and »why« of goal pursuits: Human needs and the self-determination of behavior. Psychological Inquiry, 11 (4), 227-268. DOI: 10.1207/ S15327965PLI1104_01

Dubreuil, P., Forest, J., Courcy, F. (2014). From strengths use to work performance: The role of harmonious passion, subjective vitality, and concentration. The Journal of Positive Psychology, 9 (4), 335-349. DOI: 10.1080/17439760.2014.898318

Dweck, C. (2016). What having a "growth mindset« actually means. Harvard Business Review, $13,213-226$.

Dyllick, T. H. (2018). Motto-Goals: Emotional and Motivation Effects in the Context of Unpleasant Obligations. Dissertation, Universität Mannheim.

Dysvik, A., Kuvaas, B., Gagné, M. (2013). An investigation of the unique, synergistic and balanced relationships between basic psychological needs and intrinsic motivation: Basic psychological needs and intrinsic motivation. Journal of Applied Social Psychology, 43 (5), 1050-1064. DOI: $10.1111 /$ jasp. 12068

Fredrickson, B. L., Levenson, R. W. (1998). Positive emotions speed recovery from the cardiovascular sequelae of negative emotions. Cognition \& Emotion, 12, 191-220. DOI: 10.1080/ 026999398379718

Fredrickson, B. L., Mancuso, R. A., Branigan, C., Tugade, M. M. (2000). The undoing effect of positive emotions. Motivation and Emotion, 24 (4), 237-258.

Fredrickson, B. L., Tugade, M. M., Waugh, C. E., Larkin, G. R. (2003). What good are positive emotions in crisis? A prospective study of resilience and emotions following the terrorist attacks on the United States on September 11th, 2001. Journal of Personality and Social Psychology, 84 (2), 365-376. DOI: 10.1037/0022-3514.84.2.365

Gagné, M., Deci, E. (2005). Self-determination theory and work motivation. Journal of Organizational Behavior, 26, 331-362. DOI: 10.1002/job.322

Jamieson, J. P., Crum, A. J., Goyer, J. P., Marotta, M. E., Akinola, M. (2018). Optimizing stress responses with reappraisal and mindset interventions: an integrated model. Anxiety, Stress \& Coping, 31 (3), 245-261. DOI: 10.1080/10615806.2018.1442615 
Kasser, V. G., Ryan, R. M. (1999). The relation of psychological needs for autonomy and relatedness to vitality, well-being, and mortality in a nursing home. Journal of Applied Social Psychology, 29 (5), 935-954. DOI: 10.1111/j.1559-1816.1999.tb00133.x

Krause, F., Storch, M. (2017). Ressourcen aktivieren mit dem Unbewussten: Manual und ZRM-Bildkartei. Bern: Hogrefe.

Lambert, M. J., Barley, D. E. (2001). Research summary on the therapeutic relationship and psychotherapy outcome. Psychotherapy: Theory, Research, Practice, Training, 38 (4), 357-361. DOI: 10.1037/0033-3204.38.4.357

Lang, P. J., Greenwald, M. K., Bradley, M. M., Hamm, A. O. (1993). Looking at pictures: Affective, facial, visceral, and behavioral reactions. Psychophysiology, 30 (3), 261-273. DOI: 10.1111/ j.1469-8986.1993.tb03352.x

Lyubomirsky, S., King, L., Diener, E. (2005). The benefits of frequent positive affect: Does happiness lead to success? Psychological Bulletin, 131 (6), 803-855. DOI: 10.1037/0033-2909.131.6.803

Paunesku, D., Walton, G. M., Romero, C., Smith, E. N., Yeager, D. S., Dweck, C. S. (2015). MindSet Interventions Are a Scalable Treatment for Academic Underachievement. Psychological Science, 26 (6), 784-793. DOI: 10.1177/0956797615571017

Penninx, B. W. J. H., Guralnik, J. M., Bandeen-Roche, K., Kasper, J. D., Simonsick, E. M., Ferrucci, L., Fried, L. P. (2000). The protective effect of emotional vitality on adverse health outcomes in disabled older women. Journal of the American Geriatrics Society, 48 (11), 1359-1366. DOI: 10.1111/j.1532-5415.2000.tb02622.x

Quigley, K. S., Lindquist, K. A., Feldman Barrett, L. (2014). Inducing and measuring emotion and affect: Tips, tricks, and secrets. In H. T. Reis \& C. M. Judd (Eds.), Handbook of research methods in social and personality psychology ( $2^{\text {nd }}$ ed., pp. 220-252). New York: Cambridge University Press.

Roth, G., Assor, A., Kanat-Maymon, Y., Kaplan, H. (2007). Autonomous motivation for teaching: How self-determined teaching may lead to self-determined learning. Journal of Educational Psychology, 99 (4), 761-774. DOI: 10.1037/0022-0663.99.4.761

Ryan, R. M., Deci, E. L. (2008). From ego depletion to vitality: Theory and findings concerning the facilitation of energy available to the self. Social and Personality Psychology Compass, 2 (2), 702-717. DOI: 10.1111/j.1751-9004.2008.00098.x

Ryan, R. M., Frederick, C. (1997). On energy, personality, and health: Subjective vitality as a dynamic reflection of well-being. Journal of Personality, 65 (3), 529-565. DOI: 10.1111/j.14676494.1997.tb00326.x

Ryan, R. M., Huta, V., Deci, E. L. (2008). Living well: A self-determination theory perspective on eudaimonia. Journal of Happiness Studies, 9 (1), 139-170. DOI: 10.1007/s10902-006-9023-4

Steurer-Stey, C., Storch, M., Benz, S., Hobi, B., Steffen-Bürgi, B., Steurer, J., Puhan, M. A. (2015). Motivational training improves self-efficacy but not short-term adherence with asthma self-management: a randomized controlled trial. Primary Health Care Research \& Development, 16 (1), 32-41. DOI: 10.1017/S1463423613000480

Storch, M., Gaab, J., Küttel, Y., Stüssi, A.-C., Fend, H. (2007). Psychoneuroendocrine effects of resource-activating stress management training. Health Psychology, 26 (4), 456-463. DOI: 10.1037/0278-6133.26.4.456

Storch, M., Keller, F., Weber, J., Spindler, A., Milos, G. (2011). Psychoeducation in affect regulation for patients with eating disorders: A randomized controlled feasibility study. American Journal of Psychotherapy, 65 (1), 81-93. DOI: 10.5167/uzh-49624

Storch, M., Krause, F. (2017). Selbstmanagement - ressourcenorientiert: Theoretische Grundlagen und Trainingsmanual für die Arbeit mit dem Zürcher Ressourcen Modell. Bern: Hogrefe.

Storch, M., Olbrich, D. (2011). Das GUSI-Programm als Beispiel für Gesundheitspädagogik in Präventionsleistungen der Deutschen Rentenversicherung. In W. Knörzer, R. Rupp (Hrsg.), Gesundheit ist nicht alles - was ist sie dann? Gesundheitspädagogische Antworten (S. 111-126). Baltmannsweiler: Schneider-Verlag Hohengehren. 
Tugade, M. M., Fredrickson, B. L. (2004). Resilient individuals use positive emotions to bounce back from negative emotional experiences. Journal of Personality and Social Psychology, 86 (2), 320-333. DOI: 10.1037/0022-3514.86.2.320

Weber, J. (2013). "Turning duty into joy! « Optimierung der Selbstregulation durch Motto-Ziele. Dissertation, Universität Osnabrück.

Weinstein, N., Ryan, R. M. (2011). A self-determination theory approach to understanding stress incursion and responses. Stress and Health, 27 (1), 4-17. DOI: 10.1002/smi.1368

Yeager, D. S., Johnson, R., Spitzer, B. J., Trzesniewski, K. H., Powers, J., Dweck, C. S. (2014). The far-reaching effects of believing people can change: Implicit theories of personality shape stress, health, and achievement during adolescence. Journal of Personality and Social Psychology, 106 (6), 867-884. DOI: $10.1037 / \mathrm{a} 0036335$

\section{Weiterführende Literatur}

\section{Für die Anwendung von Motto-Zielen im Coaching}

Storch, M., Faude-Koivisto, F. (2014). Ressourcen aktivieren mit Mottozielen. In A. Ryba, D. Pauw, D. Ginat, S. Rietmann (Hrsg.), Professionell Coachen. Das Methodenbuch: Erfahrungswissen und Interventionstechniken von 50 Coachingexperten (S. 334-347). Weinheim: Beltz.

Storch, M., Krause, F. (2017). Selbstmanagement - ressourcenorientiert: Theoretische Grundlagen und Trainingsmanual für die Arbeit mit dem Zürcher Ressourcen Modell. Bern: Hogrefe.

Weber, J., Storch, M. (2018). Motivation und Zielbindung mit Motto-Zielen im Coaching. In S. Greif, H. Möller, W. Scholl (Hrsg.), Handbuch Schlüsselkonzepte im Coaching (S. 391-400). Heidelberg: Springer.

\section{Für spezifische Anwendungsfelder}

Adlmaier-Herbst, G., Storch, M., Storch, J., Breiter, A. (2018). Change-Management - so klappt's! Die vier ZRM-Innovationen für den erfolgreichen Wandel. Göttingen: Hogrefe.

Riedener-Nussbaum, A., Storch, M. (2014). Ich pack's! Selbstmanagement für Jugendliche. Ein Trainingsmanual für die Arbeit mit dem Zürcher Ressourcen Modell ZRM (3. Auflage). Bern: Huber. 


\title{
Through the eye of the camera: \\ Experiences of video-mediated coaching ${ }^{1}$
}

\author{
Claudia Deniers
}

Against the backdrop of the growing integration of technology into coaching, this qualitative study investigates the coachees' perceptions of being coached via the video-conferencing platform Skype. Accounts of eleven interviewees are analysed through Interpretative Phenomenological Analysis. Findings show that the existence of a camera in the coaching encounter impacts the self-image of the coachee, the perception of the coach and the coaching space. The video-mediated set-up makes coachees acutely aware of their appearance on the screen. The perception of the coach is influenced by the limitation of visual information imposed by the position and angle of the camera. The coaches' locations generally are reported as having little influence on the perception of the coaching encounter. Overall, coachees narrate their experience in Skype coaching in terms of choice and control, indicating a strong sense of agency, attributing the coach a smaller presence compared to a face-to-face encounter. Findings will enable coaching professionals using video technology to enhance the impact of their sessions by aligning their contracting, the set-up of their sessions and the coaching encounter accordingly.

Since coaching evolved as an industry in the 1990s, its target groups and application fields have multiplied (Kanatouri \& Geißler, 2017, p. 715). At the same time, technology has affected the coach-client interaction (Sherpa Executive Coaching Survey, 2017). Penetration and usage of the Internet are high, with, for example, $89 \%$ of households in the UK having Internet access and $82 \%$ using the Internet daily (Office for National Statistics, 2016). Coaching practitioners increasingly make use of technological media and the dyadic face-to-face meeting in real time is no longer the standard mode for a coaching session to take place. To enhance convenience, location independence and cost effectiveness, 
coaching happens via video, text messages, email or via specifically created platforms, either synchronously or asynchronously, using a single way of delivery or choosing a blended approach (Clutterbuck, 2010; Boyce \& Hernez-Broome, 2010; Otte, Bangerter, Britsch, \& Wüthrich, 2014; Kanatouri \& Geißler, 2017).

One seemingly obvious way of re-creating a face-to-face situation while reaping the benefits of technology is the use of a webcam or video-conferencing device in order to connect a physically dispersed coaching pair. The ICF Global Coaching Study 2016 reports that two thirds of 15,380 coaches from 137 countries use an audio-video platform. The Sherpa 2017 report evaluates responses from 900 coaching practitioners from 65 countries, reporting $21 \%$ of all coaching services were delivered remotely.

While these industry-led reports are based on information provided by coaches, the present study aims to investigate the individual experience of clients engaged in a video-mediated coaching relationship, starting from the research question: »What is the impact of the camera in Skype coaching on the coachees' experience of being coached? «

\section{Literature review}

In reviewing the literature pertinent to the subject of the present study, three opical areas were investigated: First, literature on the use of technology in coaching in general and in career coaching in particular was analysed. Secondly, research on the working alliance in a technology-supported coaching relationship was examined. Closely related to this proved the question of the comparability between virtual and face-to-face coaching encounters. Thirdly, due to the focus of the research topic on coaching via Skype, academic literature on the specifics and challenges of communication via video-conferencing tools was explored.

\section{The use of technology in (career) coaching}

The search for research on the technology facilitated delivery of coaching yielded many results relating to therapy rather than coaching (Cook \& Doyle, 2002; Hanley, 2009; Anthony, 2015; Blake Buffini \& Gordon, 2015; Day \& Schneider, 2002; Suler, 2004; Weitz, 2014). The key topics addressed here, namely effectiveness, the functioning of the working alliance and the comparability to faceto-face interactions, are also recurrent concerns in the literature on (career) coaching using technology. 
Two recent relevant literature reviews were found: Ghods and Boyce (2013) examine the existing literature on virtual coaching against the backdrop of research into online therapy and eMentoring, while Kanatouri and Geißler (2017) provide an outline of existing purpose-built technologies to support the coaching process as well as a compilation and review of empirical research on technology-assisted coaching. As Web 2.0 technology has only been available since 2003, the year which also saw the introduction of Skype, most studies investigating the use of technology in coaching have so far primarily focused on the use of the telephone (Charbonneau, 2002; Berry, 2005; Frazee, 2008; Ghods, 2009; McLaughlin, 2012; Geißler, Hasenbein, Kanatouri, \& Wegener, 2014).

Kanatouri and Geißler come to the conclusion that »overall, the coaching literature has mainly provided positive findings with regard to the efficacy of telephone and online tools for coaching delivery« (2017, p. 725). Further research will have to show whether the continuous spread of video-conferencing technology in coaching will go along with an ever more favourable response to this form of delivery.

\section{The working alliance in technology-assisted coaching}

The quality of the coach-client relationship is generally recognised as the single most important factor determining the effectiveness of coaching (Berry, Ashby, Gnilka, \& Matheny, 2011; McLeod, 2013; Ianiro \& Kauffeld; 2014). Bordin's (1979) definition of the working alliance in therapy as comprising of a mutual agreement on tasks and goals as well as the establishment of a bond formed by trust, acceptance and confidence »is generally considered to be transtheoretical« (Berry et al., 2011, p. 244).

Across all coaching fields, »the central role of the coaching working alliance for coaching success « (op. cit., p. 232) is recognised, widely accepting McKenna and Davis' (2009) claim that $30 \%$ of the success of therapy - and by inference coaching - is accounted for by the working alliance. »So, it is important to think about how to build and sustain the alliance with a remote client. How much of the work can be done remotely without eroding this active ingredient of relationship? (op. cit., p. 258).

With the growing use of technology-supported coaching, the definition of what constitutes »face-to-face« interaction has broadened. Thus, Drake II (2015) subsumes physical and video-mediated encounters under »face-to-face coaching « opposing it to »technology-based mediated communication « where »coach and client are engaged using email, instant messaging (IM), mobile/smartphone telephone, tablet, or texting « (op. cit., p. 26). Similarly, Simeonsdotter Svensson, 
Pramling Samuelsson, Hellström and Jenholt Nolbris (2014) state: »Skype allows face-to-face communication at a distance« (op. cit., p. 1018). A critical debate whether video-mediated and face-to-face can be used synonymously could help clarify terms and both the researchers' and the clients' frames of reference.

\section{Eye contact and self-perception in video-mediated communication}

Two aspects of video-mediated communication are relevant to the purpose of the current study: the role of eye contact and the effect of seeing one's own image during the interaction. Bohannon, Herbert, Pelz and Rantanen (2013), Grayson and Monk (2013) as well as Jaklič, Solina and Šajn (2017) affirm the importance of mutual gaze for interpersonal communication and investigate the challenges of making eye contact in video conferencing where the camera is usually mounted above the screen. In her review of studies focusing on eye contact in video-communication, Bohannon et al. (2013) summarises that "research indicates that video-conferencing has an impact on verbal and non-verbal communication, also affecting social constructs such as trust and impression formation « (op. cit., p. 184). Also, self-image concerns were found to be prevalent amongst users of video-conferencing tools (de Vasconselos Filho, Inkpen, \& Czerwinski, 2009; Brubaker, Venolia, \& Tang, 2012; Hassell \& Cotton, 2017), especially in tools like Skype, where one's own video feed cannot be hidden.

\section{Methodology and research design}

The study takes a qualitative approach and a constructivist epistemological stance, assuming that »truth and meaning do not exist in some external world but are created by the subject's interactions with the world « (Gray, 2014, p. 20). Consequently, an interpretative theoretical view is adopted and a methodology chosen that is firmly rooted in the principle of phenomenology, namely Interpretative Phenomenological Analysis (IPA) as developed by Smith from the late 1990s (Smith, 1995; Smith, Jarman, \& Osborn, 1999; Smith, 2004; Smith, Flowers, \& Larkin, 2009).

Three fundamentals of IPA are relevant to the purpose of this study: it adheres to the phenomenological position originally developed by Husserl, insofar as $»$ it is concerned with an individual's personal perception or account of an object or event as opposed to an attempt to produce an objective statement of the object or event itself « (Smith et al., 1999, p. 218). Secondly, »IPA ... recognises the central role for the analyst in making sense of that personal experience«, cap- 
turing this aspect by coining the term of »double hermeneutic (Pietkiewicz \& Smith, 2014, p. 8): the participants create their interpretation of their personal experience while, at the same time, the researcher interprets this account. This admittance and constant reflection (Smith et al., 1999) of the researcher's active involvement in the creation of the participants' narrative has been critiqued as possibly devaluing the validity and generalisability of the research outcome (Brocki \& Wearden, 2006; Pringle, Drummond, McLafferty, \& Hendry, 2011), yet for this study, it is seen as an enabling and enriching proposition: with the researcher being a coach employing Skype coaching herself, the acknowledgment and constructive self-reflection of her role in the account of the experience under investigation was found to be essential.

Finally, IPA adheres to the principle of ideography, allowing for an »in-depth analysis of single cases and examining individual perspectives of study participants in their unique contexts « (Pietkiewicz \& Smith, 2014, p. 8). This principle fits in with the study's aim to give detailed analyses of a small number of people's real experience in Skype coaching.

\section{Participants and sampling}

The study adheres to the Code of Human Research Ethics prescribed by the British Psychological Society (2010). Informed consent was insured and confidentiality and the right to withdraw at any time guaranteed.

All participants met the defined pre-requisites, being:

- adults

- with an excellent command of English

- having received coaching in a career-related context

- having conducted their coaching relationship exclusively or predominantly over Skype

- prepared to conduct an interview about their experience using Skype.

The sample was not purposive in terms of gender, age, nationality or location. Of the eleven participants, five were female and six male, ranging in age from early twenties to late fifties. They were of British, Chinese, Venezuelan, South African and Bosnian nationality and resided in the UK, Singapore, Vietnam, Belgium, Germany and China at the time of the interviews. This demographic and geographic variety serves as an indication of the heterogeneity of clients deciding to be coached via Skype.

The interviews lasted between 50 and 75 minutes, were audio-recorded, transcribed verbatim and analysed consecutively. Key themes were identified and 
matching quotes were pasted under these initial headings. In an iterative process, some of these themes were renamed, and sub and overarching themes identified.

\section{Findings}

The analysis of the participants' accounts of being coached via Skype shows that the camera is felt to be the defining element of the process: »This is the virtual world and you can only see via this camera " (Interviewee 4). The effects of the camera are ambiguous: it serves as an enabler of contact, it is perceived as a means of surveillance or its presence can create an atmosphere of being on stage or a film set. Overall, the camera makes an impact in three areas:

- The self-image of the coachee in the encounter is defined by their engagement with the camera.

- The perception and the relationship with the coach is influenced by the intermediary of the camera.

- The experience of the space coaching takes place in is affected.

\section{The perspective of the coachee: Keeping things under control}

Interviewee 4 emphasised: "The virtual environment changes me and how I think of people«, summing up what most participants describe from different angles: when engaging in coaching using a web cam, very specific considerations and concerns arise, many of them related to a strong wish of staying in control of the situation. One example is the urge to check one's appearance on screen, a phenomenon studied in users of video-conferencing systems by de Vasconcelos Filho et al. (2009). Their findings correlate with what participants of the current study related: their perceived image during the interaction is of high importance to them and makes them inspect their appearance in their own video feed, particularly at the beginning of sessions (op. cit., p. 260). Also, participants cherished the possibility of choosing the location in which to take coaching and to be able to decide what elements of their surroundings to present to their coach. Most of them felt most comfortable doing the sessions at home, in their own territory, where they feel »safe« (Interviewee 4).

In addition to their self-image and their location, participants also wanted to control the coach: some interviewees felt the need to move away from the camera, so they could see more of the coach and gain assurance about what they were doing with their hands (Interviewee 11) and many voiced their preference for Skype over telephone coaching, just because it gives them at least 
some visual clues to assure them of their coach's undivided attention. Finally, the option to turn off the video feed and thus reduce the coach to voice only was named as another way of exerting control in the coaching situation. One interviewee reported switching frequently between audio only and video plus audio during sessions, with being on audio only having the advantage of "not being watched «, which for this interviewee is equivalent to »not being judged « (Interviewee 8).

\section{The perception of the coach: A ॥talking head»}

Several interviewees report the coach to be perceived as objectified and transportable:

"I would have my coach on the screen.« (Interviewee 1)

»I can put [the coach] to one side in terms of the voice." (Interviewee 8)

»I find it easier to concentrate when I have her in my ear.» (Interviewee 3).

The way coaches are experienced is reduced to their voice as transmitted through the computer and their facial expressions. Being "a face on a screen " (Interviewee 10) reduces the coach's presence and possibly also minimises the authority they might radiate in the physical world (Suler, 2004).

For a coach working with Skype, being switched on and off at the coachee's discretion or being asked to show their hands to prove they are not doing anything the coachee might disapprove of might be new experiences that possibly come as part and parcel of a new understanding of coaching, brought about by the integration of technology: "The industry must now embrace this disruptive paradigm shift, which puts the client in charge. They can have a coach in their pocket via a smartphone for when they need support and advice« (Jackson, Tawadros, \& Tinker, 2017).

In Skype coaching, the coach has not dwindled to pocket but to screen size, a fact that had an impact on all the participants in this study. Licoppe and Morel (2012) coin the term »talking heads arrangement« to describe the default mode for video communication, where »both participants [are] on screen and facing the camera" (op. cit., p. 426). This reduced perception has implications for the "communication bandwidth" (Bohannon et al., 2012, p. 137) accessible for coaching interaction: with a non-physical meeting already excluding the sense channels of touch and smell, the rigid and reductionist set-up of the video-encounter also reduces the variability of gaze, gesture and posture, which all are integral parts of visual behaviour (Whittaker \& O'Connaill, 1997, p. 25). 


\section{The coaching space: So big and yet so small}

Many participants reported that Skype coaching gave them a bigger choice of coaches by bridging geographical distance: "I'd rather have a professional on Skype than someone with lesser capabilities in person. It's the quality first and then the medium " (Interviewee 3). Several interviewees worked with coaches located in different countries or even on different continents. In this sense, Skype certainly makes the coaching space bigger than it ever has been before. On the other hand, due to the spatial limitation of the computer screen, it also brings with it an aspect of confinement, as experienced by Interviewee 3: "There is nowhere to go. You can't look out the window and you can't just take a break, you are actually paying complete attention, because it's a captive audience, 100 per cent captive. "Interviewee 10, on the contrary, experienced "an extra sense of freedom ... so there is more kind of freedom around me ... I can do different things, I can do things that I wouldn't normally do, you know with someone else in the room. "Revealing a similar width of reactions, the physical disparity of spaces was felt both as a "sense of intimacy in that [the coach] is inviting you into her space (Interviewee 1) and as bringing about irritation and confusion: "I wasn't sure what physical space I was in " (Interviewee 5).

Apparently, the "appropriate contextualization of users' interactions [required] in a virtual space« (Wilbur, 1997, p. 353) very much depends on preconceptions on the side of both coach and coachee as well as on their mutually developed understanding, a process, which cannot be explored further within the scope of this study.

\section{Conclusion}

This study investigates the coachees' individual perceptions of receiving career coaching via the video-conferencing tool Skype. It shows that the presence of a camera in the coaching encounter impacts the self-image of the coachees as well as their perception of the coach and their experience of the space coaching takes place in.

Distance coaching incorporating video technology will probably gain even broader acceptance with growing coverage of broadband Internet and refinements in HD technology. The insights provided will enable coaching professionals using video technology to align their contracting, the set-up of their sessions and the coaching encounter accordingly. The same applies for managers leading and coaching remotely and HR professionals setting up video-supported coaching and mentoring schemes. 
Three aspects of career coaching via Skype that are not covered in this study stand out as needing investigation: firstly, an analysis of Skype-mediated coaching from both the coachee and the coach's perspective could give insights into the interaction and mutual influence on behaviour and perception taking place in video-mediated coaching.

Secondly, cultural differences in attitudes and valuations of coaching through a web cam are worth researching. With the different levels of comfort with eye contact in different cultures being a well researched fact (Bohannon et al., 2012, p. 178), it would be helpful to understand how this impacts the effect of a form of coaching where constant eye contact is enforced by the medium. And finally, it remains to be analysed whether there are differences in how people from various age groups engage with this type of coaching. This research interest could be geared towards coachees of different age groups; but with many career practitioners being »digital immigrants« working with »digital natives (Bimrose \& Barnes, 2010), it is also worth investigating how coaches and coachees work together across a possible digital generation gap.

\section{References}

Anthony, K. (2015). Training therapists to work effectively online and offline within digital culture. British Journal of Guidance \& Counselling, 43 (1), 36-42.

Berry, R. M. (2005). A comparison of face-to-face and distance coaching practices: The role of the working alliance in problem resolution. Unpublished doctoral dissertation, Georgia State University, Atlanta, GA.

Berry, R. M., Ashby, J. S., Gnilka, P. B., Matheny, K. B. (2011). A comparison of face-to-face and distance coaching practices: Coaches' perceptions of the role of the working alliance in problem resolution. Consulting Psychology Journal: Practice and Research, 63 (4), 243-253.

Bimrose, J., Barnes, S.-A. (2010). Labour Market Information (LMI), Information Communication Technologies (ICT) and Information, Advice and Guidance (IAG): the way forward. UKCES. https:// www2.warwick.ac.uk/fac/soc/ier/publications/2010/bimrose_lmi_and_ict_2010.pdf [11.3.2016].

Blake Buffini, K., Gordon, M. (2015). One-to-one support for crisis intervention using online synchronous instant messaging: evaluating working alliance and client satisfaction. British Journal of Guidance \& Counselling, 43 (1), 105-116.

Bohannon, L. S., Herbert, A. M., Pelz, J. B., Rantanen, E. M. (2013). Eye contact and video-mediated communication: A review. Displays, 34 (2), 177-185.

Bordin, E. S. (1979). The generalizability of the psychoanalytic concept of the working alliance. Psychotherapy: Theory, Research \& Practice, 16 (3), 252-260.

Boyce, L. A., Hernez-Broome, G. (2010). E-coaching: Consideration of leadership coaching in a virtual environment. In D. Clutterbuck, Z. Hussain (Eds.), Virtual coach, virtual mentor (pp. 139-174). Charlotte, NC: IAP Information Age Publishing.

British Psychological Society (2010). Code of Human Research Ethics. Leicester.

Brocki, J., Wearden, A. (2006). A critical evaluation of the use of interpretative phenomenological analysis (IPA) in health psychology. Psychology and Health, 21 (1), 87-108. 
Brubaker, J., Venolia, G., Tang, J. (2012). Focusing on shared experiences: moving beyond the camera in video communication. Proceedings of the Designing Interactive Systems Conference, 11 June 2012, 96-105.

Charbonneau, M. A (2002). Participant self-perception about the cause of behavior change from a program of executive coaching. Unpublished doctoral dissertation, Alliant International University, Los Angeles, CA.

Clutterbuck, D. (2010). Welcome to the world of virtual coaching and mentoring. In D. Clutterbuck, Z. Hussain (Eds.), Virtual Coach, Virtual Mentor. Charlotte, NC: Information Age Publishing.

Clutterbuck, D., Hussain, Z. (2010). Virtual coach, virtual mentor. Charlotte, NC: Information Age Publishing.

Cook, J. E., Doyle, C. (2002). Working alliance in online therapy as compared to face-to-face therapy: preliminary results. Cyberpsychology \&behaviour: the impact of the Internet, multimedia and virtual reality on behavior and society, 5 (2), 95-105.

Day, S. X., Schneider, P. L. (2002). Psychotherapy using distance technology: A comparison of face-to-face, video, and audio treatment. Journal of Counseling Psychology, 49 (4), 499-503.

Deniers, C. (2019). Experiences of receiving career coaching via Skype: An interpretative phenomenological analysis. International Journal of Evidence Based Coaching and Mentoring, 17 (1), 72-81. DOI: 10.24384/r4j8-hm94

Drake II, L. M. (2015). Two kinds of presence: A comparative analysis of face-to-face and technology based mediated communication methods and the executive coaching experience. Unpublished doctoral dissertation, Fielding Graduate University, Santa Barbara, CA.

Frazee, R. V. (2008). E-coaching in organizations: A study of features, practices, and determinants of use. Unpublished doctoral dissertation, San Diego University, San Diego, CA.

Geißler, H., Hasenbein, M., Kanatouri, S., Wegener, R. (2014). E-Coaching: Conceptual and empirical findings of a virtual coaching programme. International Journal of Evidence Based Coaching and Mentoring, 12 (2), 165-186.

Ghods, N. (2009). Distance Coaching: The Relationship between the Coach-Client Relationship, Client Satisfaction and Coaching Outcomes. Unpublished doctoral dissertation, San Diego University, San Diego, CA.

Ghods, N., Boyce, C. (2013). Virtual coaching and mentoring. In J. Passmore, D. Peterson, T. Freire (Eds.), The Wiley-Blackwell handbook of the psychology of coaching and mentoring (pp. 501523). Chichester: John Wiley \& Sons.

Gray, D. E. (2014). Doing Research in the Real World. London: Sage.

Grayson, D. M., Monk, A. F. (2003). Are you looking at me? Eye contact and desktop video conferencing. ACM Transactions on Computer-Human Interaction (TOCHI), 10 (3), 221-243.

Hanley, T. (2009). The working alliance in online therapy with young people: preliminary findings. British Journal of Guidance \& Counselling, 37 (3), 257-269.

Hassell, M. D., Cotton, J. L. (2017). Some things are better left unseen: Toward more effective communication and team performance in video-mediated interactions. Computers in Human Behavior, 73, 200-208.

Ianiro, P. M., Kauffeld, S. (2014). Take care what you bring with you: How coaches' mood and interpersonal behavior affect coaching success. Consulting Psychology Journal: Practice and Research, 66 (3), 231-257.

ICF (2016). 2016 ICF Global Coaching Study. Study Details and Key Findings Germany. www.coachfederation.de/files/2016_icf_gcs_germany_vs._global_stand_v02_06.08.2016_mfjb.pdf [27.7.2017].

Jackson, A., Tawadros, T., Tinker, D. (2017). Virtual Reality: Adapt to our digital world or it's the end of for traditional coaches and mentors. Coaching at Work, 12 (2). https://www.coachingat-work.com/2017/03/02/virtual-reality/ [28.6.2017].

Jaklič, A., Solina, F., Šajn, L. (2017). User interface for a better eye contact in videoconferencing. Displays, 46, 25-36. 
Kanatouri, S., Geißler, H. (2017). Adapting to Working with New Technologies. In T. Bachkirova, G. Spence, D. Drake (Eds.), The SAGE Handbook of Coaching (pp. 715-730). London: SAGE.

Licoppe, C., Morel, J. (2012). Video-in-Interaction: »Talking Heads« and the Multimodal Organization of Mobile and Skype Video Calls. Research on Language and Social Interaction, 45 (4), 399-429.

McKenna, D. D., Davis, S. L. (2009). Hidden in Plain Sight: The Active Ingredients of Executive Coaching. Industrial and Organizational Psychology, 2 (3), 244-260.

McLaughlin, M. (2012). Less is more: The executive coach's experience of working on the telephone. Unpublished Master's Thesis, Oxford Brookes University, UK.

McLeod, J. (2013). An introduction to counselling ( $5^{\text {th }}$ ed., revised \& updated). Buckingham: Open University Press.

Office for National Statistics (2016). Internet Access - Households and Individuals: 2016 Use of the internet by adults in Great Britain including mobile access, activities, shopping, security and storage. https://www.ons.gov.uk/peoplepopulationandcommunity/householdcharacteristics/ homeinternetandsocialmediausage/bulletins/internetaccesshouseholdsandindividuals/2016 [27.7.2017].

Otte, S., Bangerter, A., Britsch, M., Wüthrich, U. (2014). Attitudes of coaches towards the use of computer-based technology in coaching. Consulting Psychology Journal: Practice and Research, $66(1), 38-52$.

Pietkiewicz, I., Smith, J. A. (2014). A practical guide to using Interpretative Phenomenological Analysis in qualitative research psychology. Czasopismo Psychologiczne - Psychological Journal, 20 (1), 7-14.

Pringle, J., Drummond, J., McLafferty, E., Hendry, C. (2011). Interpretative phenomenological analysis: a discussion and critique', Nurse Researcher, 18(3), 20-24.

Sherpa Executive Coaching Survey (2017). 12th annual industry review. www.sherpacoaching.com/ pdf\%20files/2017_Executive_Coaching_Survey_PUBLIC.pdf [20.2.2020].

Simeonsdotter Svensson, A., Pramling Samuelsson, I., Hellström, A.-L., Jenholt Nolbris, M. (2013). Experiences of SKYPE communication in education and research - data collection concerning young children with long-term illness. Early Child Development and Care, 184 (7), 1017-1030.

Smith, J. A. (1995). Semi-structured interviewing \& qualitative analysis. In J. A. Smith, R. Harré, L. Van Langenhove (Eds.), Rethinking Methods in Psychology, London: Sage.

Smith, J. A. (2004). Reflecting on the development of interpretative phenomenological analysis and its contribution to qualitative research in psychology. Qualitative Research in Psychology, $1(1), 39-54$.

Smith, J. A., Jarman, M., Osborn, M. (1999). Doing Interpretative Phenomenological Analysis. In M. M. K. Chamberlain (Ed.), Qualitative health psychology (pp. 281-240). London: Sage.

Smith, J. A, Flowers, P., Larkin, M. (2009). Interpretative phenomenological analysis: theory, method, research. London: Sage.

Suler, J. (2004). The Online Disinhibition Effect. CyberPsychology \& Behavior, 7 (3), 321-326.

Vasconcelos Filho, J. de, Inkpen, K., Czerwinski, M. (2009). Image, appearance and vanity in the use of media spaces and video conference systems. Proceedings of the ACM 2009 international conference on supporting group work, 10 May 2009 (pp. 253-262).

Weitz, P. (Ed.) (2014). Psychotherapy 2.0: Where Psychotherapy and Technology Meet. London: Karnac.

Whittaker, S., O'Conaill, B. (1997). The Role of Vision in Face-to-Face and Mediated Communication. In K. E. Finn, A. J. Sellen, S. B.Wilbur (Eds.), Video-Mediated Communication (pp. 23-50). Mahwah, NJ: Lawrence Erlbaum Associates.

Wilbur, S. B. (1997). Models and Metaphors for Video-Mediated Communication. In K. E. Finn, A. J. Sellen, S. B. Wilbur (Eds.), Video-Mediated Communication (pp.351-362). Mahwah, NJ: Lawrence Erlbaum Associates. 


\title{
Die Bedeutung der modernen Medien für die Professionalität von Coachingausbildungen
}

\author{
Harald Geißler
}

Im ersten Teil dieses Beitrags wird zunächst ein Überblick über die grundlegenden Merkmale moderner Coachingmedien gegeben und dann ein Praxisbeispiel einer online durchgeführten Coachingausbildung für das Coaching mit modernen Medien vorgestellt. Auf dieser Grundlage wird im zweiten Teil die Bedeutung der modernen Medien für die Professionalität bzw. Professionalisierung von Coachingausbildungen diskutiert. Je nach konzeptionellem Betrachtungsstandpunkt kommt man dabei zu unterschiedlichen Antworten. Als weiterführend erscheint in diesem Zusammenhang die Professionalisierungstheorie von Ulrich Oevermann. Mit Bezug auf diesen Ansatz lässt sich zeigen, dass die modernen Medien im Vergleich zu face-to-face durchgeführten Ausbildungen andere raumzeitliche Strukturvoraussetzungen anbieten. Denn die Coachingerfahrungen, die Ausbildungsteilnehmende als Coachees online machen, werden deutlich weniger durch gruppendynamische Prozesse überformt. Das begünstigt die Professionalität von Coachingausbildungen.

\section{Konzeptionelle Grundlagen der modernen Coachingmedien}

Um die Frage zu diskutieren, welche Bedeutung die modernen Medien für die Professionalität bzw. Professionalisierung von Coaching und Coachingausbildungen haben und welche konzeptionellen Vorstellungen über Professionalität und Professionalisierung dabei zugrunde gelegt werden können, ist es sinnvoll, zunächst die Bedeutung der modernen Medien zum einen für Coaching (»Konzeptionelle Grundlagen der modernen Coachingmedien«) und zum anderen für Coachingausbildungen (»Coachingausbildungen mit modernen Medien«) zu reflektieren.

Im Gegensatz zur Theorie und Praxis der Online-Beratung (Kühne \& Hintenberger, 2009; Engelhardt \& Storch, 2013), die sich im Praxisfeld der Sozialen 
Arbeit seit mehr als zwanzig Jahren etabliert hat, wird die Nutzung moderner Medien für Coaching vergleichsweise wenig thematisiert - und zwar ganz unabhängig davon, ob es um traditionelle Coachingmedien (Schreyögg, 2012) oder um moderne Medien (z. B. Armutat et al., 2015; Berninger-Schäfer, 2018; Heller, Triebel, Hauser \& Koch, 2018; Kanatouri \& Geißler, 2016) geht. Aus diesem Grund muss man Coaching ein technologisches Innovationsdefizit attestieren (Geißler \& Michael, 2014).

Um diese Auffälligkeit zu erklären und gleichzeitig eine konzeptionelle Vorstellung moderner Coachingmedien zu entwickeln, ist es sinnvoll, die modernen Medien, die für Coaching und Beratung genutzt werden können, in zwei Gruppen oder Typen zu unterteilen, nämlich in Kommunikations- und Problemlösungsmedien.

Erstere dienen dazu, die Kommunikation zwischen Coaches und Coachees beziehungsweise zwischen Beratenden und Ratsuchenden orts- und gegebenenfalls auch zeitunabhängig zu machen. Zu nennen sind hier zum einen die synchronen Kommunikationsformate der Video-, Audio- und Text-Chats sowie die Kommunikation mit Avataren in virtuellen Räumen (Bredl, Bräutigam \& Herz, 2012), zum anderen die asynchronen Formate der Video-, Audio- und Textbotschaften.

Diese insgesamt sieben Formate werden im Coaching und in der psychosozialen Beratung unterschiedlich genutzt. Einer der wichtigsten Gründe hierfür ist darin zu suchen, dass Online-Beratung in die Strukturen verbandsspezifisch organisierter Sozialer Arbeit integriert ist und sich auf dieser Grundlage weithin auch an Ratsuchende wendet, die anonym bleiben wollen. Aus diesem Grunde bietet sich - neben der telefonischen Beratung - vor allem die asynchrone und synchrone Textkommunikation an (Reindl, 2018, S. 17). Coaching hingegen ist mehr marktwirtschaftlich ausgerichtet und wendet sich an Zielgruppen, die eher die Telefon- und Videokommunikation bevorzugen (Geißler, 2018a).

Schauen wir zusätzlich auch auf die elektronischen Problemlösungsmedien, fällt auf, dass die modernen Medien, die in der Online-Beratung genutzt werden, im Wesentlichen Kommunikationsmedien sind und zusätzliche Problemlösungsmedien relativ wenig genutzt werden (Kühne \& Hintenberger, 2009). Das ist ein weiterer Unterschied zwischen Coaching und Beratung (Geißler, 2018c).

Das zentrale Merkmal aller Coaching- und Beratungsmedien ist ihr technischer Charakter. Er wird an zwei Stellen besonders deutlich, nämlich bei der Produktion und bei der Vermittlung bzw. den Rezeptionsbedingungen der für Kommunikation notwendigen Sinnesdaten. Während diese sich im Face-toFace-Coaching auf alle fünf Sinne beziehen, werden im Coaching mit modernen Medien nur das Hören und/oder Sehen aktiviert. Diese Restriktion wird 
unter den Stichworten Media-Richness (Daft \& Lengel, 1986; Dennis \& Kinney, 1998; Geißler, 2017) oder Kanalreduktion (Döring, 2003) diskutiert.

Schauen wir in diesem Sinne auf die Produktion von Video- und Audio-Chats sowie Video- und Audiobotschaften, erkennen wir, dass die Kommunikationspartner*innen ihre kommunikationsrelevanten Sinnesdaten, also ihre stimmlichen beziehungsweise sprachlichen Laute sowie die Visualität ihrer Mimik, Gestik und ihrer äußerlichen körperlichen Erscheinung (also z. B. Kleidung und Frisur), auf natürliche Weise generieren, das heißt ohne jede Hilfe elektronischer Technik.

Damit unterscheiden sie sich von synchronen Text-Chats und asynchronen Textnachrichten. Denn die kommunikationsrelevanten Sinnesdaten, die diese Kommunikationsformate charakterisieren, sind elektronisch generierte Zeichen. Ähnlich ist es auch bei der Avatar-Kommunikation. Denn die Visualität virtueller Welten, der äußerlichen körperlichen Erscheinung des Avatars sowie falls technisch realisierbar - auch seiner Mimik und Gestik, wird ganz und gar elektronisch generiert.

Betrachten wir die Vermittlung bzw. die Rezeptionsbedingungen der - auf natürliche oder technische Weise generierten - kommunikationsrelevanten Sinnesdaten, erkennen wir, dass die Media Richness von Video-Chats und Videobotschaften nur um ein Geringes niedriger ist als in der Face-to-Face-Kommunikation. Denn die Rezipient ${ }^{\star}$ innen können nur akustische und visuelle Kommunikationsdaten empfangen. Dabei ist allerdings anzumerken, dass die akustischen Kommunikationsdaten relativ vollständig vermittelt werden - allerdings nur dann, wenn der Sender oder die Senderin das Mikrofon angestellt hat. Ganz anders ist es bei den visuellen Kommunikationsdaten. Denn diese hängen davon ab, ob die Senderin ihre Kamera anstellt bzw. wie sie sie einstellt. Die Augen des Empfängers sehen deshalb nur das, was die Kamera aufnimmt. Auf dieser Grundlage ist wechselseitiger Blickkontakt nicht möglich, und aufgrund der Einäugigkeit der Kamera sind die Bilder, die der Empfänger wahrnimmt, immer nur 2-D-visuell.

Im Vergleich hierzu ist die Media Richness im Audio-Chat und bei Audiobotschaften deutlich geringer; am geringsten ist sie bei synchronen Text-Chats und asynchronen Textbotschaften.

Wenden wir uns nach der Betrachtung der Coaching-Kommunikationsmedien im Folgenden nun auch noch den eingangs angesprochenen CoachingProblemlösungsmedien zu. Auch sie lassen sich in Gruppen clustern, nämlich in coachingunspezifische Coaching-Problemlösungsmedien, wie zum Beispiel Word-Dokumente oder Powerpoint-Folien, und in solche, die speziell für Coa- 
ching entwickelt worden sind, wie zum Beispiel »CAI«(Berninger-Schäfer, 2018), »Virtuelles Coaching (VC)« (Geißler, 2018b), »Coachingspaces« (Krause, 2018) oder »ProReal« (Tawadros, Tinker \& Jackson, 2018).

Beide Gruppen lassen sich mit Bezug auf drei grundlegende Merkmale, die unterschiedlich stark ausgeprägt sein und sich unterschiedlich miteinander verbinden können, beschreiben, nämlich Textlichkeit, 2-D-Visualität und 3-D-Visualität.

Mit Blick auf diese Merkmale ist es möglich, die Strukturbedingungen der verschiedenen Koppelungsmöglichkeiten von Kommunikations- und Problemlösungsmedien zu ermitteln und sie zu den technischen Voraussetzungen und technischen Qualifikationen, die Coaches und Coachees für ihre jeweilige Nutzung benötigen, in Beziehung zu setzen. Auf dieser Grundlage lässt sich dann abschätzen, welche Coachingmedien sich günstig mit welchen Coachingmethoden verbinden lassen, das heißt, welche Medien-Methoden-Kombinationen für welche Zielgruppe, Coachingthemen und -ziele am besten geeignet sind, in welchen Coachingphasen sie sinnvoll genutzt werden können und last not least welche Qualifikationen Coaches hierfür haben müssen.

Diese komplexen Bedingungs- und Wirkungszusammenhänge sind zu beachten, wenn wir uns mit Evaluationsstudien auseinandersetzen, die sich mit Telefoncoaching (Berry, 2005; Charbonneau, 2002; Frazee, 2008; Ghods, 2009) oder E-Mail-Coaching (Poepsel, 2011) auseinandersetzen oder sich auf die Verbindung von Telefoncoaching mit textbasierten Problemlösungstools (Geißler, Hasenbein, Kanatouri \& Wegener, 2014) beziehen.

\section{Coachingausbildungen mit modernen Medien}

Coaching mit modernen Medien durchzuführen, verlangt entsprechende Qualifikationen. Diese Einsicht lenkt unsere Aufmerksamkeit auf die Bedeutung, die moderne Medien zum einen für die Vermittlung dieser speziellen Qualifikationen und zum anderen für die Vermittlung von Coachingqualifikationen im Allgemeinen haben können.

Wenn wir zunächst auf die Möglichkeiten schauen, welche die elektronischen Kommunikationsmedien in dieser Beziehung anbieten, können wir feststellen, dass sich für das Management von Organisationsfragen vorrangig die asynchrone Textkommunikation und gegebenenfalls auch die Telefonkommunikation

anbieten. Bei der Durchführung der Lerneinheiten, das heißt bei den Gruppenbesprechungen und Trainingseinheiten, in denen sich die Kursteilnehmenden 
unter Anleitung der Trainer gegenseitig coachen, dominiert hingegen die synchrone Videokommunikation.

Auf dieser Grundlage lassen sich zwei Typen von Online-Coachingausbildungen unterscheiden. Das sind zum einen solche, in denen mit traditionellen Coaching-Problemlösungsmedien gearbeitet wird: Als Beispiel ließe sich die Coachingausbildung von Erickson International (https://erickson.edu/onlinecoach-training-erickson-academy) anführen. Die Alternative sind online durchgeführte Coachingausbildungen, die sich auf die Nutzung moderner CoachingProblemlösungsmedien beziehen. Zu nennen wäre hier die Coachingausbildung des Karlsruher Instituts (www.karlsruher-institut.de/onlinecoach) und diejenige von online-coaching-lernen (www.online-coaching-lernen.de). Auf Letztere wird im Folgenden vertieft eingegangen.

Eine erste Teilantwort auf die Frage nach der Bedeutung der modernen Medien für Coachingausbildungen lautet also: Die modernen Medien können für Coachingausbildungen zwei Funktionen erfüllen, denn sie können erstens als Kommunikationsmedien dienen und zweitens den Lerninhalt bestimmen, nämlich Coaching mit modernen Medien (siehe Tabelle 1).

Diese doppelte Funktion soll im Folgenden kurz anhand des Curriculums der Online-Coachingausbildung online-coaching-lernen (Geißler, 2017, 2019) illustriert werden.

Diesem Curriculum liegen drei Kriterien zugrunde. Das erste bezieht sich auf den Grundgedanken, den Prozess des aus neun Modulen bestehenden und sich über neun Monate erstreckenden Qualifizierungsprozesses an einer allgemeingültigen Phasenstruktur von Coachingprozessen zu orientieren. In diesem Sinne fokussieren

- Modul 1 und 2 auf die Klärung des Coachinganliegens, -ziels- und -auftrags,

- Modul 3 und 4 auf die Soll-Ist-Analyse der Coachingthematik,

- Modul 5 und 6 auf die Entwicklung einer Lösungsstrategie und die Planung der ersten Problemlösungsaktivitäten,

- Modul 7 und 8 auf die Umsetzungsunterstützung der weiteren Problemlösungsaktivitäten

- und Modul 9 auf das Abschlussgespräch.

Das zweite Kriterium, das die curriculare Struktur dieser Online-Coachingausbildung bestimmt, bezieht sich auf die elektronischen CoachingKommunikationsmedien, die für Coaching besonders wichtig sind, und das dritte Kriterium auf ausgewählte elektronische Coaching-Problemlösungsmedien (siehe Tabelle 1). 
Tabelle 1: Die curriculare Struktur der Online-Coachingausbildung ONLINE-COACHINGLERNEN (Geißler, 2017, 2019)

\begin{tabular}{|c|c|c|c|c|}
\hline \multirow[t]{2}{*}{ Modul } & \multirow{2}{*}{\multicolumn{2}{|c|}{$\begin{array}{c}\text { Ausbildungs- } \\
\text { Kommunikations- } \\
\text { medien }\end{array}$}} & \multicolumn{2}{|c|}{ Coachingmedien } \\
\hline & & & Coaching-Kommunikationsmedien & Coaching-Problemlösungsmedien \\
\hline 1 & \multirow{9}{*}{\multicolumn{2}{|c|}{ 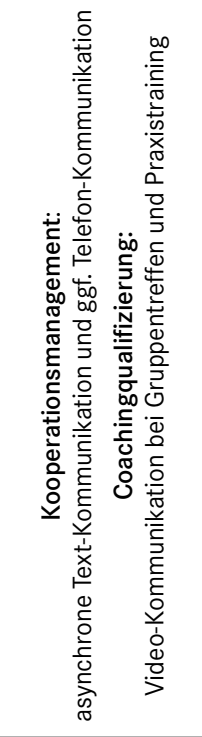 }} & (asynchr.) Audio-Botschaften & $\begin{array}{l}\text { „Virtuelles Coaching-Bedarfsermitt- } \\
\text { lung }(V C-B) \lll \& \text { ZRM } ® \text { Online-Tool }\end{array}$ \\
\hline 2 & & & (synchr.) Audio-Kommunikation & $\begin{array}{l}\text { „Virtuelles Coaching-Bedarfsermitt- } \\
\text { lung }(\text { VC-B)« \& ZRM } ® \text { Online-Tool }\end{array}$ \\
\hline 3 & & & $\begin{array}{l}\text { Video-Botschaften mit anschlie- } \\
\text { Bender Video-Kommunikation }\end{array}$ & Powerpoint-Folien \\
\hline 4 & & & $\begin{array}{l}\text { Sequenzierung von Video- } \\
\text { und Audio-Kommunikation }\end{array}$ & $\begin{array}{c}\text { „Virtuelles Zielerreichungs- } \\
\text { coaching (VZC)« \& »CoSpaces» }\end{array}$ \\
\hline 5 & & & $\begin{array}{l}\text { Sequenzierung von Video- } \\
\text { und Audio-Kommunikation }\end{array}$ & $\begin{array}{c}\text { »Virtuelles Zielerreichungs- } \\
\text { coaching (VZC)« \& »CoSpaces» }\end{array}$ \\
\hline 6 & & & $\begin{array}{l}\text { Sequenzierung von Video- } \\
\text { und Audio-Kommunikation }\end{array}$ & $\begin{array}{l}\text { »Virtuelles Zielerreichungs- } \\
\text { coaching (VZC)« \& »ProReal» }\end{array}$ \\
\hline 7 & & & $\begin{array}{l}\text { Sequenzierung von Video- } \\
\text { und Audio-Kommunikation }\end{array}$ & $\begin{array}{l}\text { „Virtuelles Zielerreichungs- } \\
\text { coaching (VZC)« \& »ProReal» }\end{array}$ \\
\hline 8 & & & $\begin{array}{l}\text { E-Mail-Kommunikation } \\
\text { mit anschließender Video- } \\
\text { und Audio-Kommunikation }\end{array}$ & $\begin{array}{l}\text { »Virtuelles Zielerreichungs- } \\
\text { coaching }(\mathrm{VZC}) \lll\end{array}$ \\
\hline 9 & & & $\begin{array}{l}\text { Sequenzierung von Video- } \\
\text { und Audio-Kommunikation }\end{array}$ & $\begin{array}{l}\text { »Virtuelles Abschlusscoaching } \\
\text { (VAC)» }\end{array}$ \\
\hline
\end{tabular}

Diese curriculare Struktur ist die Grundlage zum einen für virtuelle Gruppentreffen, in denen die Kursteilnehmenden ihre Lernerfahrungen austauschen und von der Kursleitung fachliches Grundlagenwissen erhalten, und zum anderen für die Praxisübungen, in denen sich die Kursteilnehmenden gegenseitig coachen. Ebenso wie bei face-to-face durchgeführten Ausbildungen sind die Peer-Coachings auch in online durchgeführten Ausbildungen für die Vermittlung handlungspraktischer Coachingkompetenzen und damit für die Professionalität einer jeden Coachingausbildung von zentraler Bedeutung. Schauen wir deshalb noch etwas genauer auf die Strukturbedingungen der hier vorzustellenden Coachingausbildung und auf die didaktische Gestaltung der Peer-Coachings.

Ein erstes didaktisches Merkmal besteht darin, dass Letztere auf vierzig Minuten beschränkt werden, damit anschließend genügend Zeit für das Feedback der anderen Kursteilnehmenden und der Kursleitung bleibt und auch dafür, dass die Kursleitung für etwa zehn Minuten in die Rolle des Coaches schlüpft und den zuvor unterbrochenen Coachingprozess fortsetzt. Diese sogenannten Master-Coachings werden in den letzten fünf Minuten diskutiert, indem die Kursteilnehmenden die gerade demonstrierten Coaching-Skills kurz besprechen. 
Diese Organisationsform verlangt und stellt sicher, dass alle Kursteilnehmer*innen in jedem Modul einmal Coachee und einmal Coach und in allen anderen Praxisübungen des jeweiligen Moduls Beobachtende und Feedbackgebende sind.

Wesentlich ist weiter, dass von allen Gruppentreffen und Praxisübungen Videodokumente erstellt werden, die auf einer Plattform, für alle Teilnehmer ${ }^{*}$ innen jederzeit zugänglich, abgelegt werden. Auf diese Weise können diejenigen, die an einer Sitzung nicht teilnehmen konnten, diese sozusagen nachholen. Zu dieser Funktion kommt hinzu, dass es den Lernprozess intensiviert, wenn man ein aktuell als Coach oder Coachee erlebtes Coaching anschließend noch einmal anschaut. Und drittens ist es sinnvoll, bei der Vorbereitung einer Coachingsitzung noch einmal genau hinzusehen und hinzuhören, was in der letzten Sitzung passiert ist.

Besonders zu erwähnen ist weiter, dass jeder Teilnehmer und jede Teilnehmerin zu Beginn des Kurses eine Coachingproblematik wählt, die über die gesamte Kursdauer bearbeitet wird. Alle Kursteilnehmer*innen erfahren deshalb in der Rolle der Coachees sehr intensiv, wie sich die eigene Coachingthematik im Durchgang durch die oben genannten fünf Coachingphasen entwickelt.

Nicht ganz unwichtig ist ferner, dass die Kursteilnehmer*innen in jedem Modul einen anderen Klienten oder eine andere Klientin coachen. Diese Regelung übt den »sanften Druck« aus, dass die Coaches sich bei der Vorbereitung auf ihr jeweils nächstes Coaching noch einmal die Videodokumente der letzten Coachingsitzungen ansehen und analysieren.

Der wichtigste Vorteil der so durchgeführten Peer-Coachings gegenüber denjenigen in face-to-face durchgeführten Coachingausbildungen gründet auf den unterschiedlichen Strukturbedingungen. Denn die Entwicklungsprozesse, welche die Kursteilnehmenden in ihrer Rolle als Coachees während der neun Monate ihrer Online-Ausbildungszeit vollziehen, werden so gut wie gar nicht von gruppendynamischen Prozessen, also zum Beispiel Pausengesprächen, beeinflusst und haben damit eine signifikant größere Nähe zu »echten « Coachings.

\section{Die Bedeutung der modernen Medien für die Professionalität von Coaching und Coachingausbildungen}

Die Beantwortung der Frage, welche Bedeutung die modernen Medien für die Qualität - das heißt Professionalität - von Coachingausbildungen haben, hängt davon ab, was man unter Professionalität versteht, ob man also das klassische 
Professionsmodell, das neoliberalistische Marktmodell oder die von Ulrich Oevermann entwickelte Professionalisierungstheorie zugrunde legt.

\section{Die Bedeutung der modernen Medien für die Professionalität von Coachingausbildungen im Lichte des klassischen Professionsmodells}

Das klassische Professionsmodell fokussiert auf staatlich geschützte Professionen als »fachspezifische Expertengruppen, die wissenschaftsbasierte Sonderwissensbestände entwickeln und verwalten sowie zur Lösung gesellschaftlich als wichtig anerkannter >lebenspraktischer Probleme (Oevermann, 1996) beitragen " (Fietze, 2015, S. 4). Vertreten durch ihre Berufsverbände, beanspruchen sie einen Exklusivitäts- und Autonomiestatus, der sie von anderen Berufsgruppen unterscheidet (Stichweh, 1994).

In diesem Modell ist Professionalisierung ein kollektiver, das heißt interpersoneller und interorganisationaler Lernprozess, dessen Subjekt eine Allianz ist, in der die Mitglieder einer Profession, ihre Berufsverbände und entsprechende staatliche Institutionen zusammenarbeiten. Das Anliegen dieses Kollektivsubjekts ist es, gemeinsam eine gesellschaftliche Nische zu definieren, zu gestalten und zu verteidigen, die den Professionsmitgliedern einen exklusiven Zugang zu attraktiven Ressourcen, vor allem Geld, Verfügungsgewalt und Ansehen, garantiert, sie dabei gleichzeitig aber auch an Regelungen bindet, welche die Interessen der Gesellschaft vertreten.

Auf dieser Grundlage stellt sich professionsintern die Lernaufgabe, die Außenbeziehungen der Profession, das heißt den Konkurrenzkampf mit anderen Professionen, erfolgreich zu managen, was allerdings nur gelingen kann, wenn in der Innenbeziehung zwischen ihren Mitgliedern, die natürlich untereinander auch in Wettbewerb stehen, »Burgfrieden« herrscht.

Schaut man, ausgehend von diesem Modell, auf Coaching und Coachingausbildungen, fällt auf der einen Seite der Zuwachs an wissenschaftlichen Studien zum Coaching auf (z. B. Bachkirova, Spence \& Drake, 2017) und auf der anderen Seite, dass diese sich nur marginal auf Coachingausbildungen beziehen (vgl. dazu den Überblick bei Klenner, 2017). Letzteres ist insofern erstaunlich, als Berufsausbildungen im klassischen Professionsmodell eine zentrale Bedeutung haben. Denn sie fungieren sozusagen als Transmissionsriemen, der den aktuellen Forschungsstand über Studien- und Prüfungsordnungen vermittelnd in die Praxis transportiert.

Noch wesentlicher als dieses Defizit aber ist, dass es den Berufsverbänden bisher nicht gelungen ist, klare, allgemein verbindliche Vorstellungen darüber zu entwickeln, welche Tätigkeiten für Coaching konstituierend sind (Fietze, 2015), 
welches Tätigkeitsfeld und welche ressourcenattraktive gesellschaftliche Nische Coaching also besetzen will. Diese Tatsache ist der wichtigste Grund für die insgesamt breit konsentierte Einschätzung, dass Coaching bisher erst einen relativ niedrigen Professionalisierungsgrad erreicht hat.

Stellt man sich auf den Standpunkt des klassischen Professionsmodells, vermittelt sich bis zum Beginn der Corona-Pandemie der Eindruck, dass die modernen Medien - zumindest momentan - nichts zur Professionalisierung von Coachingausbildungen beitragen können. Denn bis zu diesem Zeitpunkt stand unsere Gesellschaft nicht unter dem Druck, die modernen Medien auch für Coaching nutzen und Professionalitätskriterien für entsprechende Ausbildungen entwickeln zu müssen. Diese über Jahrzehnte etablierte Ausgangslage hat sich mit der Corona-Pandemie schlagartig geändert (Geißler, 2020).

\section{Die Bedeutung der modernen Medien für die Professionalität von Coachingausbildungen im Lichte des Marktmodells}

Mit Blick auf die aktuell veränderte Ausgangslage stellt sich allerdings die Frage, ob das klassische Professionsmodell in der Lage sein wird, Professionalitätskriterien für das Coaching mit modernen Medien zu entwickeln oder ob sich diese Aufgabe besser auf der Grundlage des Marktmodells lösen lässt. Denn der Grundgedanke dieses Alternativmodells ist, die als Professionalität bezeichnete Qualität von Coaching und Coachingausbildungen ausschließlich an das Urteil der Marktteilnehmenden zu binden. So betrachtet, erscheint die Professionalität von Coachingausbildungen dann als Ergebnis eines interorganisationalen Lern- bzw. Evolutionsprozesses, in dem die Anbieter*innen von Coachingausbildungen frei von staatlichen Vorgaben lernen (müssen), im Kampf mit der Konkurrenz einen angemessenen Marktanteil zu erobern und zu sichern.

Wichtiges Medium dieses Lernprozesses ist das Markturteil der Ausbildungsabsolvent ${ }^{*}$ innen. Um dieses angemessen zu erfassen, bietet Rauen (2007) einen Kriteriensatz zur Erfassung der Struktur-, Prozess- und Ergebnisqualität von Coachingausbildungen an. Dieser ist bisher allerdings nur auf Präsenzausbildungen zugeschnitten. Er müsste deshalb noch entsprechend überarbeitet und erweitert werden. 


\section{Die Bedeutung der modernen Medien für die Professionalität von Coachingausbildungen im Lichte der Professionalisierungstheorie von Oevermann}

$\mathrm{Zu}$ einer noch einmal ganz anderen Antwort auf die Frage nach der Bedeutung der modernen Medien für die Professionalität von Coachingausbildungen kommen wir, wenn wir die Professionalisierungstheorie von Oevermann (1996) zugrunde legen. Denn Professionalität wird hier nicht an die Qualitätsansprüche von Professionen oder des Marktes gebunden, sondern begründet sich auf die Professionalisierungsbedürftigkeit gesellschaftlicher Situationen, die durch Probleme dominiert werden, welche nicht mehr nur mithilfe traditioneller Routinen gelöst werden können, sondern die professionelle Hilfe von Expert*innen, das heißt von Professionals, nötig machen, die ihre Fähigkeit zu helfen in Auseinandersetzung mit der Wissenschaft erworben haben und ständig weiterentwickeln.

Diese Problemhaftigkeiten belegt Oevermann - vielleicht etwas zu dramatisierend - mit dem Begriff der Krise und meint damit den Normalfall, dass »keine bewährten Lösungen und Handlungsmöglichkeiten vorliegen, auf die das Subjekt zurückgreifen könnte« (Klenner, 2017, S. 62). Mit anderen Worten: Für Oevermann ist eine Krise die »nach einer Schließung rufende Öffnung der Zukunft« (Oevermann, 1996, S. 75).

Diese Definition korrespondiert mit der bildungstheoretischen Vorstellung, die Prange (1978) in seiner pädagogischen Anthropologie im Anschluss an die Existenzialphilosophie Heideggers vertritt. Denn für ihn ist der Mensch eine offene Bestimmtheit (a. a. O.), das heißt ein Wesen, das sich durch die Offenheit seines Zukunftshorizonts und die Notwendigkeit auszeichnet, diese Offenheit immer wieder durch Antworten auf wichtige Lebensfragen zu schließen, ohne damit allerdings jene Offenheit grundsätzlich infrage zu stellen oder aufzulösen.

Solche Zukunftsoffenheit ist für Oevermann die konstitutive Bedingung menschlicher Autonomie und Subjekthaftigkeit. Diese Erkenntnis korrespondiert mit den Vorstellungen der klassischen Bildungstheorie (z. B. Benner, 1987; Koller, 1999) und der auf Carl Rogers (1972) zurückgehenden klientenzentrierten Psychotherapie und Pädagogik.

Soll Coaching den Ansprüchen einer professionalisierten Praxis genügen, müssen, so Oevermann, Autonomie und Subjekthaftigkeit, das heißt »die SelbstBestimmung des Subjekts in der Krise und durch ihre Bewältigung « (Klenner, 2017, S. 68), oberste Kriterien sein. Das bedeutet: Coaching muss sich als subsidiäre Praxis, als Hilfe zur Selbsthilfe begründen und dabei eine Strategie zugrunde legen, die sozialtechnologische Standardisierung - und in diesem Rah- 
men auch die sozialtechnologisch standardisierte Nutzung moderner Coachingmedien - systematisch mit Klientenzentrierung verbindet.

Geht man von einem solchen Vorverständnis aus, kommt den modernen Medien für die Professionalität von Coachingausbildungen eine nicht unerhebliche Bedeutung zu. Denn Coachingausbildungen, deren zentraler Qualifizierungsinhalt das Coaching mit modernen Medien ist, fördern innovative Problembearbeitungstechniken, die gerade in und infolge der CoronaPandemie gefragt sind (Geißler, 2020). Besondere Aufmerksamkeit wird man dabei allerdings auf die Gefahr richten müssen, Coaching nicht zunehmend zu einer Sozialtechnologie zu machen, welche die oben angesprochene Autonomie, Subjekthaftigkeit und Ganzheitlichkeit aus den Augen verliert (Bachmann \& Fietze, 2018).

Um dieser Gefahr wirksam zu begegnen, bietet sich als Modell die Coachingausbildung an, die im Abschnitt »Coachingausbildungen mit modernen Medien« vorgestellt wurde. Denn sie zeichnet sich unter anderem dadurch aus, dass die Autonomie, Ganzheitlichkeit und Subjekthaftigkeit der Kursteilnehmenden, die in den praktischen Übungen die Rolle der Coachees wahrnehmen, nicht dadurch beschädigt wird, dass sie quasi zu Versuchskaninchen werden, an denen die als Coaches tätigen Kursteilnehmenden die Anwendung bestimmter mediengestützter Problembearbeitungstechniken sozialtechnologisch erproben und üben.

\section{Fazit und Ausblick}

Dieser Gedankengang macht deutlich, dass es sinnvoll ist, die Qualität, das heißt die Professionalität, von Coachingausbildungen an die Professionalisierungsbedürftigkeit von Coaching und Coachingausbildungen und die entsprechenden Strukturbedingungen zu binden. Von ganz zentraler Bedeutung ist dabei die Praxis der Peer-Coachings. Denn diese ist in Coachingausbildungen das zentrale Qualifizierungsmedium. Wie das im Abschnitt »Coachingausbildungen mit modernen Medien « vorgestellte Praxisbeispiel illustriert, bieten die modernen Medien aufgrund der Ausblendung gruppendynamischer Überformungen raumzeitliche Strukturbedingungen an, die eine deutlich größere Nähe zur »echten « Coachingpraxis haben. Aus diesem Grunde kann man zusammenfassend sagen, dass die modernen Medien für Coachingausbildungen Strukturbedingungen anbieten, die eine vergleichsweise höhere Professionalität ermöglichen.

Die dieser Erkenntnis zugrunde liegende Einschätzung, dass Peer-Coachings für die Professionalität von Coachingausbildungen von größter Bedeutung sind 
und als zentrale Qualifizierungsmedien zu betrachten sind, sensibilisiert für die weiterführende Anregung, die für Coaching und Coachingausbildungen relevanten Medien nicht nur unter technischen, sondern auch unter praxeologischen Aspekten zu betrachten. Was darunter genau zu verstehen ist und in welcher Beziehung technische und praxeologische Coaching- und Coachingausbildungsmedien stehen (können), wäre in weiterführenden Überlegungen zu entfalten (vgl. dazu auch Baecker, 2016; Geißler, 2016).

\section{Literatur}

Armutat, S., Berninger-Schäfer, E., Borlinghaus, R., Döllinger, K., Fritsch, M., Geißler, H., Grabow, C., Schnee, U., Skottki, B., Thompson, S., Ulmer, A., Wetzchewald, H. (2015). Virtuelles Coaching - Bilanz und Orientierungshilfe. DGFP-Praxispapiere, Leitfaden 08/2015. Düsseldorf: Deutsche Gesellschaft für Personalführung. https://www.dgfp.de/hr-wiki/Führen_und_coachen_in_der_Praxis.pdf [24.2.2020].

Bachkirova, T., Spence, G., Drake, D. (2017). Introduction. In T. Bachkirova, G. Spence, D. Drake (Eds.), The SAGE Handbook of Coaching (pp. 1-20), London: Sage.

Bachmann, T., Fietze, B. (2018). Die Digitalisierung von Coaching - Gedanken aus der Perspektive teilnehmender Beobachtung. Organisationsentwicklung, Supervision, Coaching (OSC), 25 (3), 281-292.

Baecker, D. (2016). Unruhe stiften: Coaching als Medium und Form. In R. Wegener, M. Loebbert, A. Fritze (Hrsg.), Coaching und Gesellschaft (S. 9-21). Wiesbaden: Springer.

Benner, D. (1987). Allgemeine Pädagogik. Weinheim: Juventa.

Berninger-Schäfer, E. (2018). Online-Coaching. Wiesbaden: Springer.

Berry, M. R. (2005). A comparison of face-to-face and distance coaching practices: The role of the working alliance in problem resolution. Unpublished doctoral dissertation, Georgia State University, Atlanta, GA.

Bredl, K., Bräutigam, B., Herz, D. (2012). Avatarbasierte Beratung und Coaching in 3D. In H. Geißler, M. Metz (Hrsg.), E-Coaching und Online-Beratung. Formate, Konzepte, Diskussionen (S. 121136) Wiesbaden: Springer VS.

Charbonneau, A. M. (2002). Participant self-perception about the cause of behavior change from a program of executive coaching. Unpublished doctoral dissertation, Alliant International University, Los Angeles, CA.

Daft, R. L., Lengel, R. H. (1986). Organizational information requirements, media richness and structural design. Management Science, 32 (5), 554-571.

Dennis, A. R., Kinney, S. T. (1998). Testing media richness theory in the new media: effects of cues, feedback, and task equivocality. Information Systems Research, 9 (3), 256-274.

Döring, N. (2003). Sozialpsychologie des Internet (2. Auflage). Göttingen: Hogrefe.

Engelhardt, E. M., Storch, D. (2013). Was ist Onlineberatung? - Versuch einer systematischen begrifflichen Einordnung der »Beratung im Internet«. e-beratungsjournal.net. Fachzeitschrift für Onlineberatung und computervermittelte Kommunikation, 9 (2), Artikel 5.

Fietze, B. (2015). Coaching auf dem Weg zur Profession? Eine professionssoziologische Einordnung. In A. Schreyögg, C. Schmidt-Lellek (Hrsg.), Die Professionalisierung von Coaching (S. 3-21). Wiesbaden: Springer.

Frazee, V. R. (2008). E-coaching in organizations. A study of features, practices, and determinants of use. Unpublished doctoral dissertation, San Diego University, San Diego, CA. 
Geißler, H. (2016). Traditionelle und moderne Medien im Coaching. In R. Wegener, M. Loebbert, A. Fritze (Hrsg.), Coaching-Praxisfelder (2. Auflage, S. 137-160). Wiesbaden: Springer.

Geißler, H. (2017). Moderne Medien im Coaching und in der Coachingausbildung. Wirtschaftspsychologie, 19 (2), 5-15.

Geißler, H. (2018a). E-Coaching - State of the art 2016. In J. Heller, C. Triebel, B. Hauser, A. Koch (Hrsg.), Digitale Medien im Coaching (S. 15-31). Wiesbaden: Springer.

Geißler, H. (2018b). Virtuelles Coaching (VC) und das in ihm enthaltene Professionswissen. In J. Heller, C. Triebel, B. Hauser, A. Koch (Hrsg.), Digitale Medien im Coaching (S. 91-102). Wiesbaden: Springer.

Geißler, H. (2018c). E-Coaching - ein Überblick. In S. Greif, H. Möller, W. Scholl (Hrsg.), Handbuch Schlüsselkonzepte im Coaching (S. 115-124). Wiesbaden: Springer.

Geißler, H. (2019). Organisationslernen in der Startphase einer Weiterbildungsorganisation. In M. Rohs, I. Schüßler, H.-J. Müller, M. Schiefner-Rohs (Hrsg.), Pädagogische Perspektiven auf Transformationsprozesse. Bielefeld: wbv.

Geißler, H. (2020). Digitalisierung von Coaching und Coaching-Ausbildungen. Die Corona-Krise als Innovationsbeschleuniger? Coaching-Magazin Online, 2020. https://www.coaching-magazin.de/beruf-coach/digitalisierung-von-coaching-und-coaching-ausbildungen [22.4.2020].

Geißler, H., Hasenbein, M., Kanatouri, S., Wegener, R. (2014). E-Coaching: Concept and empirical findings of a virtual coaching programme. International Journal for Evidence Based Coaching and Mentoring, 12 (2), 165-187.

Geißler, H., Stephan, M. (2014). Das medientechnische Innovationsdefizit von Coaching und eine Möglichkeit, es zu überwinden. In: S. M. Weber, M. Göhlich, A. Schröer, J. Schwarz (Hrsg.), Organisation und das Neue (S. 351-361). Wiesbaden: Springer VS.

Ghods, N. (2009). Distance coaching: The relationship between coach-client relationship, client satisfaction, and coaching outcomes. Unpublished doctoral dissertation, San Diego University, San Diego, CA.

Heller, J., Triebel, C., Hauser, B., Koch, A. (Hrsg.) (2018). Digitale Medien im Coaching. Wiesbaden: Springer.

Kanatouri, S., Geißler, H. (2016). Adapting to working with new technologies. In T. Bachkirova, G. Spence, D. Drake (Eds.), The SAGE Handbook of Coaching (pp. 713-738). Los Angeles: Sage.

Klenner, D. (2017). Die Übungspraxis in Coachingweiterbildungen. Strukturevaluation eines ausgewählten Formats. Wiesbaden: Springer VS.

Koller, H.-C. (1999). Bildung und Widerstand. München: Fink.

Krause, S. (2018). Online-Aufstellungen und virtuelle Coaching-Landschaften. In J. Heller, C. Triebel, B. Hauser, A. Koch (Hrsg.), Digitale Medien im Coaching (S. 117-127). Wiesbaden: Springer.

Kühne, S., Hintenberger, G. (Hrsg.) (2009). Handbuch Online-Beratung, Psychosoziale Beratung im Internet (2. Auflage). Göttingen: Vandenhoeck \& Ruprecht.

Middendorf, J. (2016). 14. Coaching-Umfrage Deutschland 2015/2016. Köln: BCO-Büro für Coaching und Organisationsberatung.

Oevermann, U. (1996). Theoretische Skizze einer revidierten Theorie professionalisierten Handelns. In A. Combe, W. Helsper (Hrsg.), Pädagogische Professionalität. Untersuchungen zum Typus pädagogischen Handelns (S. 70-182) Frankfurt a. M.: Suhrkamp.

Poepsel, M. (2011). The impact of an online evidence-based coaching program on goal striving, subjective well-being, and level of hope. Doctoral dissertation, Capella University, Minneapolis, MN.

Prange, K. (1978). Pädagogik als Erfahrungsprozess. Stuttgart: Klett-Cotta.

Rauen, C. (2007). Das Coaching-Index-Qualitätsmodell - Teil II. Coaching-Newsletter Oktober www.coaching-newsletter.de/archiv/2007/2007_10.htm [1.2.2019].

Reindl, R. (2018). Zum Stand der Onlineberatung in Zeiten der Digitalisierung. e-beratungsjournal. net. Fachzeitschrift für Onlineberatung und computervermittelte Kommunikation, 14 (1), 16-26.

Rogers, C. R. (1972). Die nicht direktive Beratung. München: Kindler. 
Schreyögg, A. (2012). Coaching. Eine Einführung für Praxis und Ausbildung (7. Auflage). Frankfurt a. M.: Campus.

Stichweh, R. (1994). Wissenschaft, Universität, Professionen. Soziologische Analysen. Frankfurt a. M.: Suhrkamp.

Tawadros, T., Tinker, D., Jackson, A. (2018). Coaching in a Virtual World - Your avatar will see you now. In J. Heller, C. Triebel, B. Hauser, A. Koch (Hrsg.), Digitale Medien im Coaching (S. 129-137). Wiesbaden: Springer. 


\title{
Digitalisierte Beratung zur effizienteren Selbstoptimierung
}

\section{Kritische Anmerkungen zu digitalen Formaten arbeitsbezogener Beratung aus einer Gouvernementalitätsperspektive}

Volker Jörn Walpuski

\begin{abstract}
»Digital(isiert)e» Beratung verspricht neben Innovation auch Flexibilität, Ubiquität, Globalität, Geschwindigkeit und Legitimität durch evidenzbasierte Wirksamkeit. Für eine sozialwissenschaftlich fundierte arbeitsweltliche Beratung wie Coaching und Supervision ist danach zu fragen, welches Menschen- und Weltbild sich hinter der Digitalisierung verbirgt und welche Anliegen sie transportiert. Dazu wird mit den Theorien Michel Foucaults der gegenwärtige Diskurs auf Steuerungslogiken und Machtverhältnisse hin kritisch analysiert. Dabei zeigt sich, dass die Digitalisierung das »Zeitalter der Gouvernementalität» (Foucault) festigt: Humanistisch geprägte Werte und Ziele wie Reflexion, Anerkennung und Selbsterkenntnis treten in den Hintergrund, während die Nutzbarmachung und Optimierung des Selbst sowie des Beratungsprozesses wichtiger werden: Beratung will und muss effizienzgetrieben ihre Wirksamkeit evidenzbasiert legitimieren, und Digitalisierung erleichtert dies.
\end{abstract}

\section{Computer Mediated Communication in der arbeitsbezogenen Beratung}

Jedes kommunikationsvermittelnde Medium hat eigene, spezifische Bedingungen. Gleichzeitig erscheint es für eine grundlegende, kritische Betrachtung nicht sinnvoll, sich an den feinen Unterschieden einzelner Softwarelösungen abzuarbeiten, sondern abstrahierend den Blick auf vier wesentliche Aspekte zu richten, in denen sich Beratung im Angesicht des Anderen von computervermittelter Beratung (CMC-Beratung) unterscheidet oder unterscheiden kann. CMC-Beratung, abgeleitet vom etablierten Begriff der Computer Mediated Communication (CMC), bietet sich dabei als Oberbegriff an, denn selten wird von »digitaler Beratung «, stattdessen aber beispielsweise von E-Coaching, Online-Beratung 
oder virtuellem Coaching gesprochen (vgl. Walpuski, 2015, S. 316). Einerseits scheint sich noch kein einheitlicher, treffender Begriff für dieses Beratungsformat gefunden zu haben, andererseits scheint dieses sich modernistisch an einen Markt anzubiedern, der permanente Innovationen und Alleinstellungsmerkmale fordert. Mit fortschreitender technischer Entwicklung wird die »digitale Beratung" weiter zu unterscheiden sein in CMC-Beratung, in der Digitaltechnik als vermittelndes Medium für die Kommunikation zwischen Menschen genutzt wird wie zu früheren Zeiten der berittene Bote, und in die algorithmenbasierte Beratung durch sogenannte künstliche Intelligenz (KI). Gegenwärtig lässt sich nur die CMC-Beratung untersuchen.

Auf dieser Grundlage sollen nun die Unterschiede in vier Aspekten beschrieben werden.

\section{Umgang mit Zeit: soziale Beschleunigung}

Hartmut Rosa (2013) beschreibt sich selbst verstärkende Prozesse der sozialen Beschleunigung, die Gesellschaft und Alltagsleben prägen. Einer von drei Schritten in diesem Prozess ist die technische Beschleunigung, die den sozialen Wandel antreibt und zu einer Gegenwartsschrumpfung führt, indem sich das Lebenstempo erhöht. Für E-Mails hat Rosa das bereits aufgezeigt: Zwar lassen sich elektronische Botschaften in kürzerer Zeit schreiben als herkömmliche Briefe, gleichzeitig steigt die Zahl geschriebener E-Mails, und die für Kommunikation genutzte Zeit wächst insgesamt sogar. Instant Messenger, möglich durch Ubiquitous Computing, treiben dies auf die Spitze: Kleinste Zeiteinheiten werden genutzt, um hochfrequent Mikronachrichten auszutauschen (ausführlicher: Walpuski, 2014, 2015). Die verschriftlichte Kommunikation nähert sich dem Gespräch an und erfüllt nahezu den Traum von Telepathie (Walpuski, 2013, 2014, 2015). Diese hochfrequente Kommunikation erfüllt kybernetische Bedürfnisse: (Wirksame) Steuerung ist auf schnelle Rückkoppelungen angewiesen und kann dann das aktuelle Handeln beeinflussen (Schaupp, 2016; Reichert, 2016).

Bezogen auf Beratungskonzepte, lässt sich Beschleunigung am deutlichsten in Ansätzen wie Speed-Coaching (vgl. Lesch, 2011, S. 137) wiederfinden: Kleine Schritte, schnelle Lösungen, und auch das Kurzgespräch in der Seelsorge (Lohse, 2003) oder die »Kurz-Zeit-Mediation« (Krabbe \& Fritz, 2009) fügen sich hier ein. Sicherlich lässt sich für krisenbedingte Interventionen oder besondere Umstände gut begründen, dass die Geschwindigkeit hilfreich oder gar lebensrettend sein kann. Vermutlich erfüllt jedoch arbeitsbezogene Beratung in Orga- 
nisationen selten die dafür notwendigen Kriterien, wenn aus dem Coach kein trivialer Therapeut (vgl. Bude, 1988) werden soll.

Durch die Digitalisierung von Beratung kann die Beratungsklientin Beratung in kleinste Alltagslücken stopfen, um auch diese bisher ungenutzten Zeiten noch vermeintlich sinnvoll auszufüllen und so den Tagesverlauf zu verdichten, während die Klientin selbst dies als Freiheit empfindet. Dass sich (kritischreflexive) Beratung kaum beschleunigen lässt, hat Austermann (2011, 2017) gezeigt: "Schneller zuhören geht nicht.« Die Beschleunigung und Verdichtung verhindert häufig die notwendige Priorisierung persönlicher Reflexions- und Entwicklungsaufgaben zugunsten von Alltagsaufgaben, weil das Operative in seiner Dringlichkeit immer wieder das Reflexive zurückdrängt. Auch dies trägt zur Entfremdung bei (Rosa, 2013).

Die für gute arbeitsbezogene Beratung notwendige kritische Reflexion (Gröning, 2016) braucht Zeit, Ruhe, Abstand und Muße, damit eine Resonanzbeziehung entstehen kann (Rosa, 2013).

Als Frage wird deutlich: Versteht sich Beratung im Sinne einer wirksam werdenden, messbare Ergebnisse hervorrufenden Steuerung oder als freier Denk- und Resonanzraum der Persönlichkeitsbildung und -reifung?

\section{Umgang mit Raum und Leib: Körperlosigkeit, Berührungs- losigkeit, Abstraktion, Enhancement}

Computervermittelte Kommunikation ermöglicht es, körperliche Barrieren relativ mühelos zu überspringen, weil sie den Körper erweitert. Unter dem Begriff »Enhancement « werden Geräte des Ubiquitous Computing als Körpererweiterungen und -verlängerungen diskutiert (Liessmann, 2016; Crawford, 2016): Sie befreien uns (scheinbar) aus der Unzulänglichkeit, nicht an mehreren Orten zugleich sein zu können, und damit aus einer Endlichkeit, aber auch aus Unzulänglichkeiten wie Ekel und Scham: Denn Glasoberflächen, auf denen dank Lotuseffekt kein Fingerabdruck zurückbleibt, standardisierte Typen, die entgegen einer Handschrift stimmungsunbeeinflusst abgebildet werden, oder die (gegenwärtig noch) Nicht-Übertragbarkeit von Körpergerüchen und -geschmäckern oder salzigen Tränen lassen computervermittelte Kommunikation aseptisch rein und perfekt erscheinen. Auch diese ausschnittsweise Wahrnehmung des Gegenübers ist digital im Sinne einer stufenweisen, kleinteiligen Auflösung. Sicherlich kann diese Kanalreduktion es erleichtern, sich auf das vorgetragene Beratungsanliegen zu konzentrieren und sich nicht ablenken zu lassen (Wenzel, 2015). Gleichzeitig stellt sich die Frage, welche Bedingungen 
eine ganzheitliche Wahrnehmung erfordert, die für das "seelische Verstehen" (Gröning, 2015, S. 104 ff.) notwendig ist. So forscht beispielsweise Martin Grunwald seit Jahren zu unserer Sensorik und weist nach, wie wichtig haptische Impulse für unser Wohlbefinden sind. Für die Beratung kann dies beispielhaft an Aufstellungen gezeigt werden: Die Figuren oder Personen bieten Texturen, ein spürbares Gewicht, eine Dreidimensionalität, ermöglichen Haptik, die eine Computersimulation (derzeit) nicht ermöglicht, weil Wischen nicht identisch mit Be-Greifen ist. "An die Stelle von Ganzheitlichkeit und Synästhesie sinnlicher Empfindung und sinnlichen Ausdrucks tritt [im Online-Coaching, VW], so scheint es, zudem eine Aufspaltung für die Inanspruchnahme technologischer Steuerungsaufgaben, die basal für die Prozessierung des Geschehens sind « (Martens-Schmid, 2018, S. 313).

Hinzu kommt eine Problematik von Authentizität durch Avatar-Identitäten: Die Körperlosigkeit ermöglicht andere Formen der Performanz, in denen ich mich gezielt inszenieren oder ausgewählt zeigen und darstellen kann. In der Telefonseelsorge sind diese Phänomene beschrieben (Bauer \& Becker, 2016), in der Beratende letztlich ebenso wenig wie Beratene überprüfen können, mit wem die Kommunikation stattfindet: Mensch oder Chatbot, eine scheinbar intelligente Maschine?! Solche missbräuchlich-manipulativen Nutzungen werden im CMC-Beratungsdiskurs bisher kaum thematisiert.

Die Körperlosigkeit computervermittelter Kommunikation fördert Prozesse der Entfremdung von Raum, Dingen und Selbst (Rosa, 2013; Crawford, 2016). Das Gegenüber kann nur kanalreduziert durch die »Linse« von Technologien mit unbekannten Interpretationen und Steuerungen (Algorithmen) gesehen werden und verschwindet dadurch teilweise aus dem Blick. Daran ändert sich auch nichts, wenn zu Recht auf gegenwärtige gesellschaftliche Realitäten hingewiesen wird (Bachmann \& Fietze, 2018; Martens-Schmid, 2018).

Als Frage wird deutlich: Versteht sich Beratung als reine, kleinteilige Technologie oder im Sinne einer Entfremdungen entgegenwirkenden Kraft, die Körperlichkeit braucht und Resonanzen und Reflexionen ermöglicht?

\section{Umgang mit Kontakt und Kontrakt: Niedrigschwelligkeit und Mühelosigkeit}

Grundlage von arbeitsbezogener Beratung sind das In-Kontakt-Kommen und die Kontraktierung der Zusammenarbeit. Sicherlich bieten niedrigschwelle Kontaktangebote auf möglichst vielen unterschiedlichen Kanälen insbesondere für krisenhafte Situationen viel Gutes (Wenzel, 2015, S. 38 f.). Gleichwohl 
muss Niedrigschwelligkeit sich die Frage stellen lassen, ob nicht auch spontane Abbrüche ebenso mühelos möglich sind. Vauseweh (2007) beschreibt beispielhaft für Chats, was Call-Center-Agents aus ihrer täglichen Arbeit kennen: Gesprächsabbrüche und Unerreichbarkeit.

Was heißt das für eine arbeitsbezogene Beratung? Reflexive Beratung ist nicht primär lösungsorientiert und kuschelpädagogisch, sondern kann und sollte auch kritisch-konfrontativ sein. Damit geht für beide Seiten die Gefahr plötzlicher Kommunikationsabbrüche einher: Aus einer bewussten oder unbewussten Abwehr bricht die Klientin im Affekt die Kommunikation ab und ist dann für Beratung nicht mehr erreichbar. Eine vergleichbare Situation der Präsenzberatung wäre es, wenn der Klient mitten in der Beratung aufsteht und den Raum verlässt oder zum Folgetermin unangekündigt nicht mehr erscheint. Aber auch der Berater könnte die CMC-Beratung jederzeit und für sich folgenlos abbrechen - für die Klientin ist das keine stabile, belastbare Beziehung zu einer präsenten, lokalisierbaren Person, sondern setzt viel Vertrauen in ein abstraktes Gegenüber voraus. Auchter (2016) beschreibt Ansätze, wie ein auf Winnicotts Verständnis fußendes »Halten« in Beratungsprozessen gelingen kann und wie notwendig dies für einen gelingenden Beratungsprozess ist. Wie lässt sich die von ihm geforderte "grundlegende haltgebende Einstellung des Supervisors« (a. a. O., S. 31) in einer CMC-Kommunikation umsetzen? Diese Frage scheint für eine arbeitsbezogene Beratung bisher unbeantwortet, und es bleibt offen, inwiefern Ansätze aus der Forschung zu Therapieabbrüchen übertragbar sind. Unbedingt gehört zur Vertrauensbildung jedoch der Schutz vertraulicher Daten. Eine wirksame Verschlüsselung der digitalen Kommunikation wäre möglich und für Beratung mehr als angeraten (Bachmann \& Fietze, 2018; Wenzel, 2015; Meßmer, Weinhardt \& Bauer, 2012), ist aber für viele Anwender*innen abschreckend aufwendig: Es kann nur erstaunen, »wie sorglos und wohl auch unwissend Coaches mit diesem Thema umgehen und Coaching über kostenlose Chat- und Videokonferenzanbieter oder über klassische E-Mail-Programme durchführen «, schreibt Berninger-Schäfer (2018, S. 214) und widmet dem Thema, von dem sie behauptet, dass sich darüber »im Online-Coaching alle einig sind « (ebd.), selbst keine zwei von 235 Seiten.

Eine bisher unbeantwortete Frage zur Niedrigschwelligkeit ist, inwieweit die Absenkung der Zugangsschwelle auch den Respekt vor dem Gegenüber sinken lässt. Dabei bietet die Kanalreduktion die Möglichkeit, ohne oder mit weniger Schamgefühlen von sich selbst zu sprechen. Gleichzeitig eröffnet sich dabei aber auch die Möglichkeit, beiderseits mit oder ohne Absicht Gewalt auszuüben, ohne die Folgen davon wahrnehmen zu können oder wahrnehmen zu müssen, beispielsweise in Form von Coachingfragen. Bachmann und Fietze (2018) skiz- 
zieren anhand von Bewertungslogiken digitaler Coaching-Vermittlungsplattformen Umkehrungen in Machtverhältnissen und die Deprofessionalierung des Coachings zur Dienstleistung.

Als Frage wird deutlich: Versteht sich Beratung als schnelles, marktgängiges Sofortangebot oder im Sinne einer verbindlichen Beziehung, deren Gestaltung anrührend, widerständig und mühevoll sein kann?

\section{Umgang mit Macht: Gouvernementalität}

Beratung kann eine Technologie der Machtausübung sein, wie Bröckling (2017) anhand zahlreicher üblicher Elemente von Beratung aufzeigt. Konkret lässt sich dies im CMC-Kontext verdeutlichen, wenn Geißler über sein "virtuelles Transfercoaching (Berger, 2012, Minute 6:04-7:20) sagt:

»Der wichtigste Erfolgsfaktor ist der freundliche Impuls, das umzusetzen, was man sich selbst vorgenommen hat. [...] Die Teilnehmer gehen ja mit gutem Willen in die Praxis, aber der Alltag überrollt sie. [...] Ich höre immer wieder von diesem seltsamen Tier, das Schweinehund genannt wird. Und dieser Schweinehund [...] sorgt dafür, dass das nicht umgesetzt wird, was die Leute sich selbst vornehmen. Die Tatsache, dass da jemand ist, der draufschaut, was ich mache, und ein genauer Telefontermin festgelegt wird, wo ich Rechenschaft ablegen muss, vor mir selbst und vor meinem Coach, wie weit ich denn jetzt gekommen bin, was von dem, was ich mir selbst vorgenommen habe, was von dem ich wirklich umgesetzt habe. Ein solcher Termin übt einen heilsamen Druck aus.«

Pointierter lässt sich kaum zeigen, wes Geistes Kind dieses »Tool « ist: Unter der Annahme, selbst gewählte Ziele zu verfolgen, schließt der »Teilnehmer« eine Art Arbeitsbündnis mit dem Coach, ihn bei der Umsetzung seiner Vorsätze beraterisch zu unterstützen, weil ihm dies allein nicht gelingt. Am Beispiel des Self-Tracking - der CMC-Beratung im Automatisationsgrad derzeit noch voraus - zeigt Gugutzer (2016) ausgehend von Hermann Schmitz, dass dies eine "Technik der Leibbemeisterung" ist: "Beherrscht, bemeistert wird hier weder die Psyche noch der Körper, sondern die leiblich spürbare Schwere, Trägheit, Müdigkeit oder Lustlosigkeit. [... Die Technik hilft] dabei vor allem deshalb, weil sie eine externe, nicht der eigenen Person zugehörige Autorität verkörper[t] « (a. a. O., S. 168 f.). Der Widerspruch dieser Selbstregierung im Sinne von Foucault zu Geißlers »humanistischen Vorstellungen« (Berger, 2012) scheint ihm 
selbst nicht aufzufallen. In Klingovskys Kritik an dieser Form des lebenslangen Lernens wird das deutlicher (Klingovsky, 2017, S. 39):

»Die Steuerungslogik des Lebenslangen Lernens lässt sich mithin genauer bestimmen als das, was Foucault `Technologien des Selbst` genannt hat: als Anleitungen, die es den Individuen ermöglichen, eine Reihe von Operationen an ihrem Denken, Handeln und ihrer Existenzweise vorzunehmen, um damit sich selbst und ihr eigenes Lernen umzugestalten. Sie dienen vor allem dazu, sich selbst, jederzeit flexibel, eigenaktiv und selbstverantwortlich, als individuelles Subjekt zu entwerfen. Die bildungspolitische Programmatik betont zwar die Autonomie und Selbstbestimmung der lernenden Subjekte. Aber so frei, wie darin unterstellt, sind sie letztlich gar nicht. Sie sind vielmehr aufgefordert, sich zu verändern, und auf welche Weise sie sich verändern sollen, geben die Technologien des Selbst vor. So kann dann [...] eine unabschließbare Dynamik der Selbstoptimierung in Gang gesetzt werden.»

Ähnlich kritisierten übrigens bereits Sozialarbeiter*innen in den 1950er Jahren Supervisionskonzepte eben wegen dieser Unabschließbarkeit und des chronifizierenden Verharrens in Ausbildungsrollen (Kelley, 1959).

Beratung kann also zumindest in Teilen der gegenwärtigen Praxis Form gouvernementaler Regierung sein: Nicht mehr humanistisch geprägte Werte und Ziele wie Reflexion, Anerkennung des Gegenübers und Selbsterkenntnis stehen im Vordergrund (Gröning, 2016), sondern die ökonomische Nutzbarmachung und die fortwährende Optimierung des unternehmerischen Selbsts (Bröckling, 2007; Schaupp, 2016) sowie des Beratungsprozesses. Die Digitalisierung ermöglicht es dabei, immer gezielter unsere Aufmerksamkeit zu gewinnen (Crawford, 2016) und durch mühelose Skalierung die Reichweite, Wirksamkeit und auch Abhängigkeit - ob für Macht- oder für wirtschaftliche Interessen deutlich zu erhöhen.

Als Frage wird deutlich: Versteht sich Beratung als ubiquitäres (Selbst-) Optimierungsinstrument oder im Foucault'schen Sinne als Kunst, sich nicht derartig regieren zu lassen?

\section{Eine Anfrage an das Verständnis arbeitsbezogener Beratung}

Computervermittelte Beratung eröffnet neue Zugänge und Möglichkeiten, für die es Anwendungsmöglichkeiten gibt. Deutlich wird jedoch, dass die »Digitalisierung « von Beratung auch die Frage nach dem Grundverständnis und der Ethik 
von Beratung stellt. Technologisierungen, Standardisierungen, Automatisation und Skalierungen lassen sich vor allem mit einem Verständnis verknüpfen, das funktionalisierend und kybernetisch wirksam wird und zur Verdichtung und Beschleunigung beiträgt. Ein solches Verständnis steht im Widerspruch zu einem ethisch verantworteten Beratungsverständnis, das kritisch-reflexives Verstehen des Einzelfalls und die Schaffung von Resonanzräumen zum Ziel hat. Dies kann nur in einem Dialog gelingen, verbunden mit der beiderseitigen Bereitschaft zur reflexiven Auseinandersetzung mit einem anderen Gegenüber. Dieser Anspruch steht im Widerspruch zur gegenwärtigen Gesellschaft, denn »in vielen [...] Produkten der Gegenwartskultur dient die Auseinandersetzung mit der Wirklichkeit über einen Repräsentationsbildschirm dazu, die Welt für ein fragiles Selbst in die Entscheidungsarchitektur einzupassen, die der für die psychologische Einstellung zuständige Funktionär gestaltet hat «(Crawford, 2016, S. 368). Eine derartige »Beratung « ist dann nicht kritischer Sand, sondern funktionalisierendes Öl im Getriebe: Sie kann in Arbeitsabläufe und die Selbststeuerung eingetaktet werden und ist dann eine »Technologie der Macht « (Foucault). Je weniger ein Mensch als beratende Person sichtbar und je mehr ein Beratungsprozess als Werkzeug (»tool«) standardisiert, evidenzbasiert und damit technologisiert wird, desto austauschbarer wird Beratung. Dass die beratende Person mit ihrer Persönlichkeit und das Vertrauen in sie in der Beratung hingegen zentral sind, hat Wandhoff (2016) in einem Gang durch Jahrhunderte nachgezeichnet. Und dass eine gelingende Beziehung ein viel wesentlicherer Faktor als die Beratungsmethode ist, hat erst kürzlich wieder Roth gezeigt (2018).

Kritisch ist also zu fragen, welche Zeiten und Räume Reflexion neben Künstler*innen benötigt, die "nicht auf diese Weise und um diesen Preis regiert" (Foucault, 1992, S. 12) werden. Deutlich wird dies, wenn ein Supervisand die stundenlange Zuganreise als wertvolle, störungsfreie Vor- und Nachbereitungszeit der Supervision beschreibt. Damit scheint Präsenzberatung nur im ersten Augenblick ökonomisch ineffizient. Bei näherem Hinsehen drängt sich der Verdacht auf, dass Präsenzberatung als gekaufte Zeit und damit Premiumangebot (Bachmann \& Fietze, 2018) für die »Wiedergewinnung des Wirklichen« (Crawford, 2016) fungieren könnte: Beratung als legitimer Grund, sich aus dem hochverdichteten Arbeitsalltag zu verabschieden und konzentriert, selbstreflexiv und mit einem begreifbaren Gegenüber an einem Entwurf für ein gelingendes Leben entlangzudenken (Wandhoff, 2016) und damit auch die Entfremdung in der Spätmoderne (Rosa, 2013) ein wenig abzumildern. 


\section{Literatur}

Auchter, T. (2016). »Halte mich fest, aber halte mich nicht fest«. Zur Bedeutung des Haltens im Supervisionsprozess aus psychoanalytischer und psychosozialer Perspektive. FoRuM Supervision. Onlinezeitschrift für Beratungswissenschaft und Supervision, 24 (47), 26-43.

Austermann, F. (2011). Schneller zuhören geht nicht - und auch nicht beschleunigt beraten: TelefonSeelsorge und Supervision in Zeiten sozialer Beschleunigung. Supervision: Mensch, Arbeit, Organisation, 29 (4), 37-41.

Austermann, F. (2017). Do acceleration and boundless work lead to accelerated and boundless coaching? In B. Geißler-Piltz, É. Nemes, S. de Roos (Eds.), Inspire and Be Inspired. A Sample of Research on Supervision and Coaching in Europe. The collected articles of the $1^{\text {st }}$ ANSE Research Conference on Supervision and Coaching, 24.-25. April 2015, Budapest, organized by ANSE, KRE, MSZCT, DGSv (pp. 115-124). Paris: L'Harmattan.

Bachmann, T., Fietze, B. (2018). Die Digitalisierung von Coaching - Gedanken aus der Perspektive teilnehmender Beobachtung. Organisationsberatung, Supervision, Coaching (OSC), 25 (3), 281-292.

Bauer, A., Becker, B. (2016). Die Fußwaschung der »Verbalerotiker«: Ideen zu - latenten und verborgenen - Inhalten und Widersprüchen der Beratungsarbeit der Telefonseelsorge. In E. Hauschildt, B. D. Blömeke (Hrsg.), Telefonseelsorge interdisziplinär (S. 295-312). Göttingen: Vandenhoeck \& Ruprecht.

Berger, L. (2012). CorporateLearningCamp 2012: Session-Vorbereitung mit Prof. Dr. Harald Geißler. 9-minütiges Videointerview, https://www.youtube.com/watch?v=AODurXjli6A [22.1.2019].

Berninger-Schäfer, E. (2018). Online-Coaching. Wiesbaden: Springer.

Bröckling, U. (2007). Das unternehmerische Selbst. Soziologie einer Subjektivierungsform. Frankfurt a. M.: Suhrkamp.

Bröckling, U. (2017). Gute Hirten führen sanft. Über Menschenregierungskünste. Berlin: Suhrkamp.

Bude, H. (1988). Beratung als trivialisierte Therapie. Über eine Form »angewandter Aufklärung « im Angestelltenverhältnis. Zeitschrift für Pädagogik, 34 (3), 369-380.

Crawford, M. B. (2016). Die Wiedergewinnung des Wirklichen. Eine Philosophie des Ichs im Zeitalter der Zerstreuung. Berlin: Ullstein.

Foucault, M. (1992). Was ist Kritik? Berlin: Merve.

Gröning, K. (2015). Theorien des Verstehens in Wissenschaft, Beratung, Supervision, Sozialer Arbeit und Psychoanalyse. FoRuM Supervision - Zeitschrift für Beratungswissenschaft und Supervision, 23 (46), 103-114.

Gröning, K. (2016). Sozialwissenschaftlich fundierte Beratung in Pädagogik, Supervision und Sozialer Arbeit. Gießen: Psychosozial-Verlag.

Gugutzer, R. (2016). Self-Tracking als Objektivation des Zeitgeists. In S. Duttweiler, R. Gugutzer, J.-H. Passoth, J. Strübing (Hrsg.), Leben nach Zahlen. Self-Tracking als Optimierungsprojekt? (S. 161-182). Bielefeld: transcript.

Kelley, E. (1959). The Development of Young Supervisors. The Catholic Charities Review, 43 (9), $15-20$.

Klingovsky, U. (2017). Lebenslanges Lernen revisited - Zur Strukturlogik der New Educational Governance in der Wissensgesellschaft. In A. Bolder, H. Bremer, R. Epping (Hrsg.), Bildung für Arbeit unter neuer Steuerung (S. 27-44). Wiesbaden: Springer VS.

Krabbe, H., Fritz, R. (2009). Die Kurz-Zeit-Mediation und ihre Verwendung in der gerichtsinternen Praxis. Teil 1: Zeitschrift für Konfliktmanagement (ZKM), (5), 136-139. Teil 2: ZKM, (6), 176-179.

Lesch, S. (2011). Psychoblasen in der Wirtschaft. Wiesbaden: Gabler.

Liessmann, K. P. (Hrsg.) (2016). Neue Menschen! Bilden, optimieren, perfektionieren. Wien: Zsolnay. 
Lohse, T. H. (2003). Das Kurzgespräch in Seelsorge und Beratung. Eine methodische Anleitung. Göttingen: Vandenhoeck \& Ruprecht.

Martens-Schmid, K. (2018). Hier ist dort - Coaching auf dem Weg in virtuelle Beratungswelten. Organisationsberatung, Supervision, Coaching (OSC), 25 (3), 305-319.

Meßmer, S., Weinhardt, M., Bauer, P. (2012). Kindeswohlgefährdung und Onlineberatung - ein Fallbeispiel. e-beratungsjournal.net. Fachzeitschrift für Onlineberatung und computervermittelte Kommunikation, 8 (1), S. 1-14.

Reichert, R. (2016). Social Surveillance. Praktiken der digitalen Selbstvermessung in mobilen Anwendungskulturen. In S. Duttweiler, R. Gugutzer, J.-H. Passoth, J. Strübing (Hrsg.), Leben nach Zahlen. Self-Tracking als Optimierungsprojekt? (S. 185-200). Bielefeld: transcript.

Rosa, H. (2013). Beschleunigung und Entfremdung. Entwurf einer kritischen Theorie spätmoderner Zeitlichkeit. Berlin: Suhrkamp.

Roth, G. (2018). Coaching und Neurowissenschaften. Organisationsberatung Supervision Coaching (OSC), 25 (1), 109-120.

Schaupp, S. (2016). »Wir nennen es flexible Selbstkontrolle«. Self-Tracking als Selbsttechnologie des kybernetischen Kapitalismus. In S. Duttweiler, R. Gugutzer, J.-H. Passoth, J. Strübing (Hrsg.), Leben nach Zahlen. Self-Tracking als Optimierungsprojekt? (S. 63-86). Bielefeld: transcript.

Vauseweh, R. (2007). Onlineseelsorge. Zur Präsentation von Seelsorge- und Beratungsangeboten im World Wide Web. Erlangen: Christliche-Publizistik-Verlag.

Walpuski, V. J. (2013). Always on - Vom Umgang mit der ständigen Erreichbarkeit. Supervision: Mensch, Arbeit, Organisation, 31 (4), 32-37.

Walpuski, V. J. (2014). Smart Devices in Organisationen - Von Regelungen für die Allgegenwärtigkeit von computergestützter Kommunikation. Organisationsberatung, Supervision, Coaching (OSC), 21 (1), 99-114. DOI: 10.1007/s11613-014-0359-z

Walpuski, V. J. (2015). Ubiquitous Computing und Gruppendynamik. Überlegungen zu Smart Devices als gruppendynamisches Phänomen. Gruppendynamik und Organisationsberatung, 46 (3-4), 313-325. DOI: 10.1007/s11612-015-0283-5

Wandhoff, H. (2016). Was soll ich tun? Eine Geschichte der Beratung. Hamburg: Corlin.

Wenzel, J. (2015). Mythos Unmittelbarkeit im Face-to-Face-Kontakt - Weiterentwicklung von Beratung und Therapie durch gezielte methodische Nutzung der Medien. e-beratungsjournal. net. Fachzeitschrift für Onlineberatung und computervermittelte Kommunikation, 11 (1), 36-54. 


\section{Coaching von Wissenschaftler*innen im Kontext der Digitalisierung}

\section{Coaching als Anker in entpersonalisierten Kommunikations- und Konfliktprozessen}

Monika Klinkhammer, Harry Enke und Neela Enke

Digitalisierung verändert nicht nur den Alltag, sondern auch die Berufsrollen von Wissenschaftler*innen nachhaltig. Neben positiven Entwicklungen - verbesserter Zugang zu wissenschaftlichen Daten, Rechnerkapazitäten für die Auswertung riesiger Datenmengen und erweiterte Möglichkeiten des Austauschs in der internationalen wissenschaftlichen Community u. a. - gilt es, auch zahlreiche Herausforderungen zu meistern: Berufliche Begegnungen im persönlichen Kontakt werden zunehmend durch digitalisierte Kommunikationsmedien ersetzt, die Taktfrequenz wissenschaftlicher Erkenntnis erhöht sich, die Verfügbarkeit von Daten allein führt noch nicht zur Bereitschaft der Wissenschaftler*innen, diese Daten zu teilen.

Digitalisierung widerspiegelt sich damit als gesellschaftliches Phänomen auch im professionellen Alltag von Wissenschaftler*innen und drückt sich auf individueller Ebene aus - zum Beispiel in Form von Überforderung oder zunehmender Isolation und besonderen professionellen Belastungen. Diese Themen tauchen als Anliegen, verdeckte Themen, Rahmenbedingungen usw. im Coaching auf.

Der Beitrag zeigt anhand von zwei Fallbeispielen, wie in der komplexen digitalisierten Welt klassisches Face-to-Face-Coaching als Anker beim Umgang von Individuen mit diesen Herausforderungen dienen kann.

Die technischen Neuerungen der letzten Jahrzehnte haben den Alltag nicht nur von Wissenschaftler ${ }^{\star}$ innen stark gewandelt. Zu den wichtigsten Veränderungen gehören neue Möglichkeiten der Kommunikation wie Videotelefonie, E-Mail oder auch die gemeinsame Arbeit online an Dokumenten. All dies schafft auf der einen Seite viele neue Chancen, zum Beispiel zur globusumspannenden Zusammenarbeit. Auf der Ebene der zwischenmenschlichen Zusammenarbeit bergen digitalisierte Kommunikationsformen aber auch Konfliktpotenzial. Rein 
schriftlich-digitale Kommunikation kann Konflikte beschleunigen und eskalieren, da es keinen direkten persönlichen Kontakt und kein Regulativ durch den sozialen Kontext gibt. Auch kann durch ein »cc« schnell eine breite Öffentlichkeit erreicht werden.

Eine weitere Veränderung ist das Phänomen von »Big Data «': Aufgrund der Verfügbarkeit riesiger Datenmengen und der Annahme, dass Big Data die Beantwortung/Beforschung großer und komplexer gesellschaftlicher oder wissenschaftlicher Fragen ermöglicht, sprießen interdisziplinäre und transdisziplinäre Forschungsprojekte und Forschungsverbünde und internationale Kooperationen aus dem Boden der traditionell recht fachspezifisch forschenden Wissenschaftswelt. Hier entstehen vielfältige und vielschichtige Konfliktlagen, die auch mit kulturellen Hintergründen (Gesellschaft, Organisationsstrukturen, Fachkulturen) verbunden sind, welche teils nicht bewusst werden und nicht benannt werden können oder dürfen. Insbesondere gibt es eine Diskrepanz zwischen den digitalen Anforderungen und der digitalen Kompetenz.

Die Datenmengen wachsen enorm, mit ihr die Hardware und die Methoden der Datenerhebung und -auswertung. Die vielen Optionen bedeuten jedoch auch die Qual der Wahl, verlangen ein Vergleichen und Messen mit Kolleg*innen, die zu ähnlichen Forschungsfeldern mit ähnlichen Methoden arbeiten. Die Vermittlung der eigenen Forschungsergebnisse wird damit komplexer. Die Digitalisierung ermöglicht eine Forschung auf einer bis dato unvorstellbaren quantitativen und qualitativen Grundlage (Big Data, IT-gestützte Datenerhebung und Auswertungsprogramme, virtuelle Feedbackgruppen und Zugang zu oder Austausch von Daten mit anderen Forschergruppen usw.). Neben den vielfältigen Forschungsmöglichkeiten und neuen Ansätzen zum Erkenntnisgewinn entstehen hier Konkurrenzen, Konflikte und Problemlagen, die erst nach und nach ins Bewusstsein der Beteiligten rücken. Organisationen und ihre spezifischen Anlaufstellen für Konflikte (Ombudsstellen, Gleichstellungsbeauftragte, Koordinator*innen von Graduierteneinrichtungen, Personalabteilungen, Personalräte usw.) werden vor völlig neue Anforderungen des

1 "Mit `Big Data $<$ werden große Mengen an Daten bezeichnet, die unter anderem aus Bereichen wie Internet und Mobilfunk, Finanzindustrie, Energiewirtschaft, Gesundheitswesen und Verkehr und aus Quellen wie intelligenten Agenten, sozialen Medien, Kredit- und Kundenkarten, Smart-Metering-Systemen, Assistenzgeräten, Überwachungskameras sowie Flug- und Fahrzeugen stammen und die mit speziellen Lösungen gespeichert, verarbeitet und ausgewertet werden « (Quelle: https://wirtschaftslexikon.gabler.de/definition/big-data-54101). Diese Daten sind heterogen und unstrukturiert und werden mit neuen Analysemechanismen erschlossen. Es ist merkwürdig, dass große wissenschaftliche Datenquellen (CERN, Teleskope usw.) in der obigen Definition gar nicht vorkommen, obwohl diese den Begriff »Big Data maßgeblich prägen. 
Konfliktmanagements gestellt, auf die sie nicht vorbereitet sind. Hier müssen neue Lösungsansätze entwickelt werden.

Wissenschaftler ${ }^{\star}$ innen und Professor ${ }^{\star}$ innen, die Koryphäen in ihrem Bereich sind, schaffen es heute selbst in ihrem spezialisierten Bereich kaum noch, $u p$ to-date zu bleiben. Sie sind auf Teamwork und Kooperation von Kolleg*innen und Mitarbeiter*innen angewiesen. Damit wandelt sich das Selbstverständnis der Profession Wissenschaft. Dies in die eigene berufliche Identität zu integrieren (Expertise des Nichtwissens) und den Wandel anzuerkennen, ist oftmals von Verunsicherung, Scham, Verleugnung, Aggressionen und Widerständen gekennzeichnet.

Einerseits gilt es, die Ambivalenz zu balancieren zwischen einem leichteren und schnelleren wissenschaftlichen Forschen und Lehren (komplexe Material-, Studien- und Literatursichtung, Datenerhebung und -auswertung, Vernetzung usw.). Anderseits müssen die mit den neuen Techniken verbundenen, vielschichtigen und vielfältigen Optionen immer wieder bewertet, müssen Entscheidungen getroffen und muss mit den Konsequenzen daraus gearbeitet werden. Forschen und Lehren wird schwieriger.

Die mit der Digitalisierung verbundenen vielfältigen Optionen und Konflikte schleichen sich meist im beruflichen Alltag ein, sind sozusagen add on (oder es sind zeitraubende, neue Projekte, neue Techniken und neue Mitarbeitende). Vereinfacht formuliert: Je höher der berufliche Status, umso selbstverständlicher, dass man sich im Selbstbild (und in den externen Rollenanforderungen) in der Profession, Disziplin, den eigenen Forschungs- und Lehrschwerpunkten mit digitalisierten Arbeitsweisen auskennen soll oder adäquates Personal finden und einstellen muss. Gelingt dies nicht oder nur unzureichend und ist keine bewusste Haltung als Expert ${ }^{\star}$ in (Fachwissen) und zugleich keine Expertise des Nichtwissens « vorhanden (Buchinger, 1998) (im Hinblick auf Steuerung von Prozessen, deren Bedingungen man nicht kennt und erst eruieren muss), umso mehr sind die damit verbundenen Themen mit Scham besetzt. Vor diesem professionsbedingten Hintergrund findet das Hochstaplersyndrom einen günstigen Nährboden (vgl. Klinkhammer \& Saul-Soprun, 2009). Berufliche und psychosoziale Belastungen nehmen zu, der Performancedruck steigt (Keupp, 2012; Kratzer, Dunkel \& Menz, 2012, Klinkhammer, 2011, 2013; Seppelt et al. 2018).

Generationenkonflikte (zwischen etablierten und neu berufenen Professor*innen) verschärfen sich um digitalisierte Forschungszugänge und -themen: Im Zuge der Profilierung ist es für sogenannte Nachwuchswissenschaftler*innen zwingend, sich mit Digitalisierung und den damit zur Verfügung stehenden methodischen und sonstigen Forschungsmöglichkeiten auseinanderzusetzen. Dies führt dazu, dass junge Wissenschaftler*innen zum einen digitale Metho- 
den heute eher lernen und insbesondere in ihrer Forschung auch anwenden. Dadurch entstehen Forschungsprofile, die im traditionellen Kanon der Wissenschaft eher unüblich sind und die insbesondere in einigen Bereichen als fremd oder zu avanciert empfunden werden.

\section{Zwei Fallbeispiele}

Die Auswirkungen, die Digitalisierung auf die alltägliche Arbeitswirklichkeit von Wissenschaftler*innen und auch auf das Individuum haben kann, und wie sich all dies im Coaching spiegelt, sollen anhand von zwei Fallbeispielen aus der Coachingpraxis "greifbar« werden.

\section{Junger Professor und Teamführung auf Distanz}

A., ein junger Professor, der vor Kurzem in Y eine Vertretungsprofessur übernommen hat, kommt mit Fragen und Herausforderungen zur Personalführung und zur weiteren Karriereplanung ins Coaching. A. steht seit Längerem unter enormem Karriere- und Zeitdruck. Um eine unbefristete Professur zu erlangen, sollte er sich weiter durch Forschung, Publikationen und Einwerbung von Drittmitteln profilieren und sich bei Fachtagungen im internationalen Kontext präsentieren. Zuvor hatte er an der Universität X eine Nachwuchsgruppe aufgebaut. A. setzt darauf, an der Universität $X$ in einem bald anstehenden Berufungsverfahren ausgewählt $z u$ werden und damit eine dauerhafte Professur und Lebenszeitverbeamtung zu erhalten. Das laufende Forschungsprojekt und die wissenschaftlichen Mitarbeiter ${ }^{*}$ innen sind - auch vor diesem Hintergrund - in X geblieben. Vorübergehend ist einem Professor und guten Kollegen die (formale) Leitung übertragen worden. Vereinbart ist aber, dass die Steuerung und Leitung der Forschergruppe weiterhin bei A. liegt und er zudem in $X$ als assoziierter Wissenschaftler platziert ist, ohne vor Ort zu sein und ohne formale Weisungsbefugnis.

Im Rahmen seiner wissenschaftlichen Schwerpunktsetzung und Profilierung sind in diesem Forschungsprojekt der Nachwuchsgruppe große Datenmengen (Big Data) zu durchleuchten. Erfolgreiche Drittmittelakquise und der Aufbau der Forschungsgruppe haben A. als Führungskraft und Wissenschaftsmanager enorm gefordert und waren auch schon bis anhin Themen im bereits länger laufenden Coaching.

In dieser Situation werden aus seinem Forschungsprojekt, ohne A.s Wissen, per E-Mail und Social-Media-Kanal Fragen zur Methodik an die Fachöffent- 
lichkeit gerichtet, die A. selbst hätte beantworten können. Er befürchtet einen Reputationsverlust in einer für ihn kritischen Berufsphase. Im Coaching thematisiert A. die damit verbundenen Herausforderungen, Probleme und Lösungsansätze.

\section{Aspekte der Digitalisierung}

Inhalt und Forschungsmethoden des Forschungsprojekts sind ebenso wie der Forschungsschwerpunkt selbst durch Digitalisierung bestimmt. Dies war bislang in A.s Fach unüblich und wird von den etablierten Professor*innen eher mit Skepsis und teils mit Abwertung der Relevanz in seiner Disziplin begegnet.

Die Digitalisierung und Big Data ermöglichen eine komplexe und differenzierte Datenerhebung und -auswertung. Dadurch werden vielfältige forschungsmethodische, -praktische und -ethische Fragen aufgeworfen. Die Führung und Kommunikation mit den Mitarbeiter*innen werden über E-Mail, Telefon- und Videokonferenzen gestaltet. Dadurch wird Führung aus Distanz technisch zwar erleichtert, zugleich aber auf der zwischenmenschlichen Ebene schwieriger und konfliktträchtiger.

Durch die Tatsache, dass ein wissenschaftlicher Mitarbeiter ohne Rücksprache mit der Projektleitung innerhalb von Sekunden bundesweit und mit dem Projektnamen verbunden ein großes Netzwerk einbeziehen kann, besteht einerseits die Möglichkeit, sehr schnell Expert*innen und Kooperationspartner*innen um Rat zu bitten. Andererseits ist so nun möglicherweise ein konkreter Reputationsschaden für A. entstanden. Er wird von Kolleg*innen auf den Hintergrund der Anfrage angesprochen und muss überlegen, ob, wie und auf welchen Kanälen er reagiert und wie Schadensbegrenzung erfolgen kann.

\section{Ergebnisse aus dem Coaching}

Im Zuge der Notwendigkeit, Führung aus der Ferne ohne formale Führungsbefugnis und via digitalisierte Kommunikation zu praktizieren, bestimmt A. sein Führungsverständnis und die Gestaltung zum Beispiel der Delegation von Teilaufgaben neu. Im Coaching selbst geht es um A.s Selbstverständnis als Führungskraft, um die Gestaltung seiner Führungsrolle sowie um strategische Fragen zur Verstetigung seiner Karriere, namentlich um die Erlangung der unbefristeten Professur in X. Die konkrete Sitzung kreist zunächst um das Thema Führung der Forschungsteams aus der Ferne. Der durch digitalisierte Kommunikationsformen entstandene Konflikt diente der Klärung, wie A. seine Führungsrolle versteht, wie er seine Aufgabendelegation unter anderem durch Mitarbeitendengespräche und Teambesprechungen optimieren könnte und was Chefsache bleiben muss. Zudem standen im Coaching Lösungsansätze zur künf- 
tigen Gestaltung der Übergangszeit ohne formale Führungsfunktion im Fokus. Es ging ferner darum, wie die Anforderungen in diesem Projekt neben anderen (und neben den ohnehin vielschichtigen Anforderungen und Aufgaben in Lehre, Forschung, Verwaltung usw.) und sonstige Aufgaben in der Vertretungszeit ausbalanciert werden könnten. Die Frage war schließlich, ob und inwiefern durch die nicht abgesprochene Aktion des Mitarbeiters Schaden für die eigene Reputation oder gar ein Gesichtsverlust entstanden ist und wie der Coachee damit weiter umgehen kann.

\section{Promovierender im einem interdisziplinären Forschungsprojekt}

In einem auf drei Jahre angelegten interdisziplinären Forschungsprojekt forschen Natur-, Sozial- und Geisteswissenschaftler ${ }^{\star}$ innen gemeinsam. B., der Coachee, ist Promovierender in diesem Projekt. Als Physiker ist er in ein Teilprojekt geraten, in dem seine Expertise als Datenanalyst gebraucht wird, während die Arbeitsgruppe und die direkte Betreuerin Geograf*innen sind. Von Beginn an fällt B. auf, dass ihm auf der einen Seite viele Fachbegriffe unbekannt sind und auf der anderen Seite seine Ansätze nicht verstanden werden und es in den Teammeetings zu vielen Missverständnissen kommt.

B.s Expertise in der Datenverarbeitung wird weder verstanden noch wahrgenommen, die Betreuerin verliert immer schneller die Geduld mit ihm, und B. fühlt sich zunehmend isoliert. Hinzu kommt, dass die Mittel für das Projekt auf drei Jahre begrenzt sind.

Als endlich eine Veröffentlichung von Teilergebnissen ansteht, treten beträchtliche Differenzen über den Ort und die Art und Weise der Veröffentlichung auf. Als Physiker ist B. aus seiner Fachdisziplin an die Nutzung von Preprint Services (arxiv) und Online-Peer-Review gewohnt und würde gerne auf einer Plattform veröffentlichen, die dies zulässt und außerdem von Forscher*innen mit ähnlicher Expertise gelesen wird. Seine Betreuerin möchte hingegen, dass er in einem zentralen Organ der Geografie mit dem klassischen Peer-ReviewVerfahren veröffentlicht.

\section{Aspekte der Digitalisierung}

Der digitale Wandel hat eine große Menge von Daten verfügbar gemacht und das Bedürfnis geweckt, damit "große«, fachübergreifende Fragestellungen zu beforschen, obschon ja Daten nicht immer ohne Weiteres bereitwillig geteilt werden (Enke et al., 2012). Außerdem gibt es eine Vielzahl interdisziplinärer Projekte. Dabei geht aber oft vergessen, dass es in den verschiedenen Fachdisziplinen sehr unterschiedliche Denk- und Forschungsansätze gibt, die nicht 
ohne Weiteres vereinbar sind. Hinzu kommen häufige »Wissens-Gaps«, sodass zum Beispiel die Forscherinnen der Fachdisziplinen nicht notwendigerweise verstehen, was die »Daten-Spezialist*innen« möchten und umgekehrt. Das Nicht-Verstehen zieht häufig Hierarchisierungs- und Abwertungsprozesse nach sich, indem diejenigen, die nicht verstehen oder nicht verstanden werden, als im Vergleich zur eigenen Disziplin - weniger gute Wissenschaftler ${ }^{\star}$ innen wahrgenommen werden. Datenauswertung und -aufbereitung werden traditionell oft als »Hilfswissenschaft « verstanden, was insbesondere bei der Entwicklung und Anwendung digitaler Methoden der Realität nicht mehr angemessen ist.

Würde der »Wissens-Gap« bei der Planung der interdisziplinären Projekte berücksichtigt, müsste es zu Beginn eine (vermutlich längere) Phase der »Verständigung « geben, in der eine Einigung auf die gemeinsame wissenschaftliche (Verständnis-)Basis erfolgt. Die Förderintervalle lassen dies jedoch oft nicht zu. So entsteht ein enormer Druck im Projekt, der im Fall des promovierenden B. zum Scheitern des Projekts führen könnte, ohne dass dies in seiner Eignung für das Projekt oder seiner wissenschaftlichen Expertise begründet wäre. Vielmehr ist das Problem dem Konflikt zwischen "vordigitalen « wissenschaftlichen Evaluierungsprozeduren und neuen Anforderungen geschuldet.

\section{Ergebnisse aus dem Coaching}

Im Einzelcoaching wurde sehr schnell deutlich, dass hier die Coachin als Ansprechperson, mit der face-to-face gearbeitet wurde, der empfundenen personellen und fachlichen Isolation positiv entgegenwirken konnte. Die unmittelbare emotionale Resonanz auf die vom Klienten erlebte konflikthafte Promotionssituation machte es für ihn möglich, im Coaching Unsicherheiten zu formulieren und Kommunikationsstrategien für die Auseinandersetzung mit seiner Betreuerin zu entwickeln. Die Entscheidung, wo publiziert wird, hat massive Auswirkung auf die Positionierung des Physikers im Forschungsgebiet und damit auf seinen Karriereverlauf.

Darüber hinaus entstand (auf Initiative von B. und nach Klärung der Implikationen bei Durchführung durch die gleiche Coachin) aus dem Einzelcoaching ein Teamcoaching, in dem es möglich wurde, die differenten Forschungsansätze und ihre Hierarchisierung zu thematisieren und die Problematik nicht mehr in der Leistungsfähigkeit einzelner Akteur*innen zu verorten, sondern auf einer organisationssystemischen ${ }^{2}$ Projektebene anzugehen.

2 »Organisationssystemisch « bedeutet hier, dass die besonderen Bedingungen der Organisationsform »interdisziplinäres Projekt « und dessen Wechsel- und Auswirkungen mit den/auf die darin arbeitenden Personen betrachtet werden. 


\section{Schlussbetrachtung - Coaching in der digitalisierten Arbeitswelt}

Die Veränderungen in Hochschulen und in der Profession Wissenschaft werden durch die Digitalisierung beschleunigt, die Reflexion und die Verankerung in der eigenen professionellen Identität (auch als Führungskraft) hinken diesen Entwicklungen hinterher. Coaching ermöglicht es, sich mit professionellen organisations- und rollenbezogen heiklen und konfliktträchtigen Fragen auseinanderzusetzen, die sich vor vielfältigen anderen Hintergründen auf der Ebene der Person spiegeln. Es bietet dabei der Person einen geschützten vertrauensvollen Raum und eine unterstützende und dialogische Beratungsbeziehung.

Im Gegensatz zu virtuellen Coachingformaten, die in einer globalisierten Arbeitswelt durchaus ihre Berechtigung haben, da auch sie Anker im Bekannten bieten können, hat das Face-to-Face-Coaching einige Besonderheiten, die gerade in einer beschleunigten, digitalen Welt positiv wirken.

In unserer Coachingpraxis hat sich immer wieder gezeigt, dass auch das Heraustreten aus dem vertrauten professionellen oder privaten Umfeld an einen Ort der Beratung einen positiven Effekt auf die Möglichkeit hat, neue Gedanken und Perspektiven zuzulassen. Gestützt und gefördert wird dieser Effekt durch eine klare und als angenehm empfundene Gestaltung des Beratungsraums und des Settings. Nach unserer Erfahrung nehmen sich Klient ${ }^{\star}$ innen beim virtuellen Coaching selten die Zeit, einen besonderen Ort zu kreieren, an dem sie wirklich zur Ruhe und Distanz kommen können. Doch gerade dieses »Heraustreten und Innehalten « und das »Sich-Zeit-Nehmen« hat in der Coachingpraxis einen großen Effekt.

Die Beratungsqualität im Face-to-Face-Coaching zeigt sich in Lebendigkeit, Sinnlichkeit, Arbeiten mit Körper, Sinnen und Emotionen im gemeinsamen Raum, mit haptisch erfahrbaren Materialien (Aufstellungsfiguren, Moderationskarten) oder über unmittelbare Körpererfahrung und -sprache (Mimik, Gestik, Lautstärke und Klangfarbe der Stimmen), Bewegung im und Nutzung des gesamten realen Raums. Auch in konflikthaft aufgeladenen Situationen zeigt sich eine direkte emotionale Resonanz, die im virtuellen Coachingraum unter Umständen so nicht möglich wäre: Studien zeigen, dass bei der videobasierten Kommunikation Emotionen und Gesichtsausdrücke nicht richtig eingeschätzt werden und Sympathie unterschätzt wird (z. B. Sears, Zhang, Wiesner, Hackett \& Yuan, 2013). All dies sind aber wichtige Werkzeuge von Coaches.

Wissenschaftler*innen haben zunehmend weniger Gelegenheit, zwischenmenschliche, auf Vertrauen basierende Arbeitsbeziehungen, in der das Gegenüber »keine Aktien in der Karriere« der ratsuchenden Person hat, aufzubauen. 
Im Coaching kann ein Coachee (vermeintliche oder gefühlte) Schwächen, Unsicherheiten, Ängste, Scham- oder Überforderungsgefühle in adäquater Form zulassen und ihre Bedeutung für die eingebrachte Situation auf einer anderen Ebene ergründen. Coaching bietet einen Anker und macht hier auch aus systemischer Sicht Sinn, beispielsweise um die "Atemlosigkeit» der Kommunikation und Beschleunigung von Forschung in einem Umfeld zu betrachten, das diese Faktoren nicht reproduziert.

"Wir verschwinden«, so beschreibt Meckel (2013), leicht überspitzt, den »Menschen im digitalen Zeitalter«. Die zunehmend durch digitale Medien vermittelte Kommunikation, in der Menschen sich »nicht persönlich « begegnen, also depersonalisiert und asynchron sich nur noch im virtuellen Raum treffen, verändert auch Wahrnehmungs-, Denk- oder Forschungsprozesse. Für die Coachingpraxis bedeutet dies, dass genau zu prüfen ist, an welcher Stelle digitale Coachingformate zu einer Reproduktion der professionellen Herausforderungen führt. Interessant bleibt, in welchem Ausmaß die mit der Digitalisierung in der "Wissenschaft" einhergehenden professionellen Herausforderungen und entpersonalisierten Kommunikations- und Konfliktprozesse sich im Coaching spiegeln werden. Bei der weiteren Professionalisierung von Coaching im Wissenschaftsfeld wäre es ein Verlust, wenn - auch aus Zeit- und Kostengründen - Face-to-Face-Coachingformate als unzeitgemäß betrachtet würden und sie rein digitalisierten Coachingangeboten weichen müssten. Damit würden wichtige Beratungsqualität und ein Anker für die in der Wissenschaft arbeitenden Menschen verloren gehen.

\section{Literatur}

Buchinger, K. (1998). Supervision in Organisationen. Heidelberg: Carl-Auer-Systeme.

Enke, N., Thessen, A., Bach, K., Bendix, J., Seeger, B., Gemeinholzer, B. (2012). The User's View on Biodiversity Data Sharing - Investigating facts of acceptance and requirements to realize a sustainable use of research data. Ecological Informatics, 11, 25-33.

Keupp, H. (2012). Riskante Chancen: Das sich selbst erschöpfende Selbst auf dem Fitnessparcours des globalen Kapitalismus. In M. Bentele, J. Fellermann (Hrsg.), Womit wir es in der Supervision und Coaching zu tun haben werden (S. 24-43). Kassel: university press.

Klinkhammer, M. (2011). Life-Coaching von Wissenschaftler/innen in der Praxis. In C. SchmidtLellek, F. Buer (Hrsg.), Life-Coaching in der Praxis (S. 251-270). Göttingen: Vandenhoeck \& Ruprecht.

Klinkhammer, M. (2013). Charakteristika und Belastungen des Arbeitsplatzes Hochschule. Organisationsberatung, Supervision, Coaching (OSC), 20 (3), 307-318.

Kratzer, N., Dunkel, W., Menz, W. (2012). Raubbau oder Rückzug? Ursachen und Folgen der systematischen Überlastung in Unternehmen. Supervision, 30 (1), 4-11. 
Klinkhammer, M., Saul-Soprun, G. (2009). Das »Hochstaplersyndrom» in der Wissenschaft. Organisationsberatung, Supervision, Coaching (OSC), 16 (2), 165-182.

Meckel, M. (2013). Wir verschwinden. Der Mensch im digitalen Zeitalter. Zürich: Kein \& Aber.

Sears, G. J., Zhang, H., Wiesner, W. H., Hackett, R. D., Yuan, Y. (2013). A comparative assessment of videoconference and face-to-face employment interview. Management Decision, 51 (8), 1733-1752. DOI: 10.1108/MD-09-2012-0642

Seppelt, R., Beckmann, M., Václavík, T., Volk, M. (2018). Scientific Life: The Art of Scientific Performance. Trends in Ecology \& Evolution, 33 (11), 805-809. 


\title{
Transformation Coaching und Generative Coaching
}

\author{
Neue Dimensionen der Coachingkultur von Organisationen \\ in der digitalen Arbeitswelt
}

Axel Klimek und Werner Stork

"The Fourth Industrial Revolution is about
empowering people, not the rise of machines."

(Brad Keywell)

Die digitale Transformation und die digitale Arbeitswelt fordern uns - wirtschaftlich und gesellschaftlich - heraus. Dieser Beitrag stellt zunächst kurz die grundlegenden Entwicklungen im Rahmen der digitalen Transformation dar und arbeitet auf dieser Grundlage heraus, wie die damit systematisch gestiegenen Unsicherheiten und Komplexitäten zu grundlegend neuen Herausforderungen in der digitalen Arbeitswelt führen. Ein Schlüssel zur Bewältigung dieser Herausforderungen liegt in der Agilität und Resilienz von Individuen ebenso wie von Organisationen. Wir zeigen, wie bestimmte Weiterentwicklungen im Coaching dazu beitragen können, diese Agilität und die Resilienz von Organisationen systematisch zu verbessern. Dabei geht es auf der einen Seite um die Implementierung einer Coachingkultur auf Organisationsebene und auf der anderen Seite um die Weiterentwicklung hin zu einem Transformation Coaching und einem Generative Coaching.

Die allgegenwärtige digitale Transformation erzeugt in den Unternehmen und Organisationen einen hohen Leistungs- und Veränderungsdruck. Angetrieben durch die neuen technologischen Möglichkeiten und die zunehmende Vernetzung von Menschen, Prozessen, Services und Daten, entstehen komplett neue Geschäftsmodelle und Wertschöpfungsketten, und in der Folge ändert sich die Arbeitswelt in den Unternehmen rapide. In der neuen, digitalen Arbeitswelt entstehen neue Berufsbilder und Rollen, viele Tätigkeiten verändern sich stark, und einige Jobs fallen auch ganz weg. Mitarbeiter ${ }^{*}$ innen müssen lernen, mit neuen digitalen Tools und Prozessen zu arbeiten; teilweise finden sie auch völlig neue Strukturen und Arbeitsweisen vor. 
Der Begriff der VUKA-Welt steht für die mit der digitalen Transformation verbundenen Volatilitäten, Unsicherheiten, Komplexitäten und Ambiguitäten. Die VUKA-Welt stellt neue und strukturell andere Anforderungen an Mitarbeitende, Teams, Führungskräfte und Organisationen. Coaching gilt traditionell als wirksame Methode und hilfreiche Haltung, wenn es darum geht, mit komplexen Situationen und großen Unsicherheiten umzugehen. Auf Basis zweier wesentlicher Dimensionen, a) Form und b) intendierte Wirkung des Coachings, können zentrale Vorteile des Coachings im Prozess der digitalen Transformation herausgearbeitet werden.

\section{Veränderungen durch die digitale Transformation}

Die digitale Transformation wird oft auch mit dem Begriff »Industrie 4.0« beschrieben. Ebenso wie die industriellen Revolutionen 1 bis $3^{1}$ ist sie von tief greifenden Veränderungen in Unternehmen und in der Wirtschaft und Gesellschaft als Ganzes geprägt. Die digitale Transformation wird dabei vor allem von zwei grundlegenden Entwicklungen vorangetrieben.

Zum einen in einem technischen Sinne durch eine Reihe von bahnbrechenden Entwicklungen, die in der Summe dazu führen, dass weite Bereiche unseres wirtschaftlichen und gesellschaftlichen Lebens digitalisiert erfasst und abgebildet werden können. Die einschlägigen Stichworte dazu sind: allgegenwärtiges High-Speed-Internet, steigender Einfluss von künstlicher Intelligenz, wachsende Einsatzgebiete von Big Data Analytics und umfassende Überführung von Daten und Informationen der Unternehmen in die Cloud.

Zum anderen durch die damit einhergehende organisatorische und kulturelle Transformation der Unternehmen und Organisationen - einer Transformation, die zwar von der Digitalisierung angetrieben wird, aber auch von anderen Faktoren - wie der Globalisierung, der demografischen Entwicklung und dem Wertewandel - entscheidend mitgeprägt wird. Diese digitale Transformation der Organisationen beschränkt sich nicht nur auf den eigentlichen betrieblichen Wertschöpfungsprozess, sondern beinhaltet darüber hinaus auch

1 Als erste industrielle Revolution wird die Zeit der frühen Industrialisierung (Massenproduktion mithilfe von dampfbetriebenen Maschinen) bezeichnet. Die zweite Industrialisierungsphase setzte etwa 1870 ein; Kern dieser Phase war die Nutzung neuer Energieformen, vor allem der Elektrizität. Die dritte Phase der Industrialisierung ist auf etwa 1970 zu datieren. Prägend ist der massenhafte Einsatz von Computern und Informationstechnologien und die weitere Automatisierung durch Elektronik. Kennzeichnend für die vierte, die digitale Revolution, die bis heute anhält, ist die zunehmende Digitalisierung. 
die systematische Vernetzung und Integration von Kunden, Lieferantinnen, der Konkurrenz und der Mitarbeiter*innen. Im immer schnelleren globalen und digitalen Wettbewerb werden alte Abläufe infrage gestellt, klassische Hierarchien lösen sich auf. In der Folge kommt es zu gravierenden Veränderungen in den Geschäftsmodellen, Strukturen, Prozessen und Arbeitsweisen der Unternehmen und Organisationen.

\section{Von kompliziert zu komplex - die VUKA-Welt der digitalen Transformation}

Die mit der digitalen Transformation einhergehenden Veränderungen und Umbrüche haben weitreichende Folgen bei den Rahmenbedingungen und Parametern für die Akteur*innen im wirtschaftlichen System. Dabei ist ein Aspekt von grundlegender Bedeutung: die Veränderungen von einem bislang komplizierten Umfeld zu einem immer komplexeren Kontext. In einem komplizierten Umfeld gibt es einen klaren Ursache-Wirkungs-Zusammenhang. Die Organisation kann diese Zusammenhänge verstehen lernen, sie kann ihre Entscheidungen logisch begründen und ihr unternehmerisches Handeln für die Zukunft langfristig planen. Die Eigenschaften eines komplexen Systems hingegen sind grundlegend verschieden. Komplexe Systeme sind dadurch gekennzeichnet, dass nicht mehr nur eine Möglichkeit besteht, ein Problem zu lösen. Stattdessen bieten sich zahlreiche Optionen mit ganz unterschiedlichen Akteuren und Maßnahmen an. Die Wirkungszusammenhänge sind (teilweise) unklar, die Daten- und Informationslage ist unübersichtlich und nicht (abschließend) analysierbar (Landwehr-Zloch \& Stork, 2019).

\section{Von ıkompliziertı zu ıkomplex॥ - Antworten aus der Coachingwelt}

Der Übergang von »kompliziert« zu »komplex« stellt keine lineare Weiterentwicklung von etwas Bestehendem dar. Während »kompliziert« eher einem mechanistischen Verständnis von Realität entspricht, spiegelt »komplex « eine systemische, sich selbst organisierende Realität wider. Um einen möglichen Mehrwert von Coaching beim Übergang von einem komplizierten Umfeld zu einem komplexen Kontext zu beschreiben, unterscheiden wir im Folgenden zwischen zwei Dimensionen, auf die der jeweilige Fokus bei der Betrachtung und Umsetzung von Coaching in Organisationen gesetzt werden kann. 
In unserem Beitrag »Coachingkultur in deutschsprachigen Organisationen Das Konzept der resilienten und agilen Organisation « (Klimek \& Stork, 2018) haben wir uns auf die Dimension »Form des Coachings« fokussiert. Coaching findet in Organisationen als Einzelcoaching, "Die Führungskraft als Coach", und als Teamcoaching statt. Mit den Herausforderungen der VUKA-Welt wird es für Organisationen notwendig, als gesamtes System agiler und resilienter auf disruptive Veränderungen zu reagieren. Um die Basis für diese systemweite Agilität und Resilienz legen zu können, ist der Aufbau einer organisationsweiten Coachingkultur hilfreich. Mithilfe einer Coachingkultur kann die Organisation hierarchieübergreifend auf das vorhandene Wissen und den Erfahrungsschatz der gesamten Organisation zugreifen und innovative Antworten auf die komplexen Herausforderungen finden (Clutterbuck \& Megginson, 2009; Hawkins, 2012).

Mit einer zweiten Betrachtungsdimension legen wir den Fokus auf die intendierte Wirkung von Coaching: In der komplizierten Welt geht es beim Coaching um die Entwicklung von Fertigkeiten (Skills Coaching), die persönlichprofessionelle Weiterentwicklung (Development Coaching) und/oder um das Sicherstellen bzw. Steigern der Performance (Performance Coaching). Für die spezifischen Herausforderungen der VUKA-Welt können das Transformation Coaching und das Generative Coaching einen zusätzlichen und notwendigen Mehrwert stiften. Ihre intendierte Wirkung liegt in der zielgerichteten Transformation oder in der bewussten Erschaffung von etwas Neuem. Beides wird im Folgenden ausführlicher und vor dem Hintergrund der Herausforderungen in der digitalen Arbeitswelt vorgestellt.

\begin{tabular}{|c|c|c|c|c|}
\hline $\begin{array}{l}\text { Fokus Form } \\
\text { Wirkung }\end{array}$ & Einzelcoaching & $\begin{array}{l}\text { Führungsraft } \\
\text { als Coach }\end{array}$ & Teamcoaching & Coachingkultur \\
\hline Skills Coaching & & & & 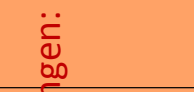 \\
\hline $\begin{array}{l}\text { Development } \\
\text { Coaching }\end{array}$ & & & & $\frac{1}{2}$ \\
\hline $\begin{array}{l}\text { Performance } \\
\text { Coaching }\end{array}$ & & & & 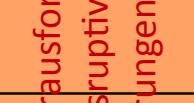 \\
\hline $\begin{array}{l}\text { Transformation } \\
\text { Coaching }\end{array}$ & $\begin{array}{l}\text { Neue } \\
\forall \cup K A\end{array}$ & $\begin{array}{l}\text { Herausforderu } \\
\text { disfuptive }\end{array}$ & ngen: & 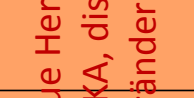 \\
\hline $\begin{array}{l}\text { Generative } \\
\text { Coaching }\end{array}$ & Verän & derungen, ... & & 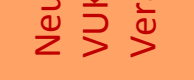 \\
\hline
\end{tabular}

Abbildung 1: Entwicklungsdimensionen von Coaching 


\section{Zur Verwendung und zum Verständnis des Begriffs "Coaching॥ in den Dimensionen "Form» und "Wirkung"}

Wenn wir beim Betrachten der Dimension "Wirkung " von Einzelcoaching sprechen, dann nutzen wir den Begriff "Coaching « in einer ähnlichen Art und Weise wie der Deutsche Berufsverband Coaching e. V. (DBVC): "Coaching ist die professionelle Beratung, Begleitung und Unterstützung von Personen mit Führungs-/Steuerungsfunktionen und von Experten in Unternehmen/Organisationen. Zielsetzung von Coaching ist die Weiterentwicklung von individuellen oder kollektiven Lern- und Leistungsprozessen bzgl. primär beruflicher Anliegen " (https:// www.dbvc.de/der-verband/ueber-uns/definition-coaching.html).

Wenn wir dagegen den Fokus auf die Dimension »Form« legen, erweitern wir das Verständnis von Coaching. »Coaching von Teams« öffnet systematisch den Blick vom Individuum zum Team, und bei Konzepten wie »Die Führungskraft als Coach « übernimmt eine Führungskraft entwicklungsorientierte Aufgaben für ihre Mitarbeiter*innen und agiert ähnlich wie ein Coach. Organisationen, die eine Coachingkultur schaffen, haben einen klaren Business Case für das Coaching entwickelt und setzen daraufhin Coaching proaktiv ein. Zusätzlich nutzen sie bewusst ausgewählte Grundelemente und Grundprinzipien des Coachings an relevanten Entscheidungspunkten im organisationalen Alltag. Sie wollen sicherstellen, dass sie auf neue Herausforderungen nicht automatisch mit gewohnheitsmäßigen Konzepten und Verhaltensweisen reagieren, sondern stattdessen das vorhandene Potenzial ihrer Mitarbeiter ${ }^{\star}$ innen nutzen, um neue Ideen und Vorgehensweisen für die Organisation zu generieren. Es geht den Organisationen dabei um Mustererkennung und um Musterveränderung auf allen relevanten Ebenen der Organisation sowie um die Entwicklung von neuen zielführenderen Handlungs- und Managementweisen (Klimek, 2019a, 2019b).

Skills Coaching findet in Situationen Anwendung, in denen es wichtig ist, dass ein Coachee bestimmte Fertigkeiten (Skills), Methoden und Vorgehensweisen lernt und beherrscht. Im Umfeld der VUKA-Welt kann es sich hier beispielsweise um neues IT-Wissen handeln oder um Methodenkenntnisse zum agilen Projektmanagement oder zur Innovationsförderung, zum Beispiel um das Konzept des Design Thinking. Beim Skills Coaching beherrscht der Coach diese Fertigkeiten, Methoden und Vorgehensweisen selber gut und kann den Coachee bei seiner Lernreise individuell begleiten.

Für Development Coaching ist charakteristisch, Führungskräfte und Mitarbeitende zu unterstützen, wenn sie in neue Rollen oder Aufgaben hineinwachsen sollen. Im Rahmen der digitalen Transformation und in der VUKAWelt kommt dies ausgesprochen häufig vor. Je nach Studie und Prognose sind 
hiervon zwischen 50 und 80 Prozent der Beschäftigten betroffen (Bonin, Gregory \& Zierahn, 2015; Landwehr-Zloch \& Stork, 2019). Beispielsweise arbeitet man neu in verteilten Teams mit einem agilen Ansatz, oder man wird zu einer deutlich stärkeren Selbstorganisation gefordert, oder das Coachen von Mitarbeitenden in der digitalen Transformation wird zur neuen Herausforderung (Laloux, 2015). Ein Coach kann hier helfen, klare und realistische Ziele für die Entwicklung zu setzen, verschiedene Optionen mental durchzuspielen, Lernerfahrungen zu reflektieren usw. Diese Art von Coaching entspricht am ehesten der ursprünglichen Idee von Coaching in Organisationen.

Während die ersten beiden Formen von Coaching hauptsächlich auf die Person(en) fokussieren, stehen beim Performance Coaching die Organisationsziele deutlich stärker im Mittelpunkt (Klimek, 2019a). Ähnlich einem Coach im Sport nimmt der Performance Coach oftmals einen aktiveren Part ein und versucht, mentale, kommunikative, kooperative und motivationale Hindernisse aus dem Weg zu schaffen, die dem Erfolg im Wege stehen.

Skills Coaching, Development Coaching und Performance Coaching haben gemeinsam, dass sie einen substanziellen Beitrag in einer komplizierten, aber auch in einer komplexen Welt leisten.

\section{Neue Antworten des Coachings auf die VUKA-Herausforderung}

In der VUKA-Welt begeben wir uns auf ein Feld von Unbekanntem, von Nichtwissen - individuell und kollektiv. Antworten aus der alten Welt, der komplizierten Welt, gehen hier oftmals nicht tief genug. Solche Antworten können sogar die Grundlage für Misserfolg sein oder den Blick auf neue Chancen verstellen, die sich durch die digitale Transformation ergeben. Abraham Maslow hat dieses Dilemma schön auf den Punkt gebracht: »Wenn dein einziges Werkzeug ein Hammer ist, sieht jedes Problem wie ein Nagel aus. "In Bezug auf die digitale Transformation und die sie charakterisierenden Eigenschaften der VUKA-Welt ist es deshalb hilfreich, das Verständnis und den Anwendungsbereich von Coaching systematisch zu erweitern (Klimek, 2019a, 2019b).

Wie in unserem oben bereits erwähnten Artikel aufgezeigt, gibt es bei der Dimension »Form « eine Entwicklung von Coaching hin zu einer organisationsweiten »Coachingkultur«. In Bezug auf die Dimension »Wirkung« kann eine Weiterentwicklung des Coachings hin zu einem Transformation Coaching (Ziel ist ein fundamentaler Paradigmenwechsel) und zu einem Generative Coaching (Entwicklung innovativer disruptiver Ideen und Ansätze) einen substanziellen 
Mehrwert schaffen (Klimek, 2019a). Bei diesen Ansätzen geht es nicht mehr in erster Linie darum, Dinge besser zu machen, sondern darum, in einer noch weitgehend unbekannten, weil sich gerade erst entwickelnden digitalen Arbeitswelt gänzlich neue Ansätze zu generieren und gleichzeitig den eigenen Bezugsrahmen von Wahrnehmung, Fühlen, Rationalisierung und Handeln kritisch zu hinterfragen.

\section{Transformation Coaching}

Dieser Ansatz im Coaching ist immer dann relevant, wenn gewohnte Einschätzungen und Vorgehensweisen als nicht mehr zielführend wahrgenommen werden und man einen fundamentalen Paradigmenwechsel anstrebt. Gewohnte Erfolgsfaktoren verlernen und zurücklassen ist dabei mindestens so wichtig, wie Neues zu entwickeln (Klimek, 2019a, 2019b).

In einem konkreten Beispiel ging es um ein Unternehmen, das Drucker und Kopierer herstellt. Die technischen Vertriebs- und Servicemitarbeitenden, sie wurden intern »Box Mover" genannt, konnten mit Begeisterung ihre ebenfalls technikinteressierten Kund ${ }^{*}$ innen auf technische Neuerungen hinweisen und waren auf diese Weise erfolgreich. Als das Unternehmen seine Strategie in Richtung Digitalisierung änderte, wurde der Fokus auf die Einbettung der Kopierer und Drucker in das Dokumentenmanagementsystem bei den Kund*innen verlagert. Dadurch ergab sich für die Vertriebsmitarbeitenden eine ganz neue Welt. Nicht mehr die technische Leiterin beim Kunden war die Ansprechpartnerin, sondern der kaufmännische Leiter. Ihm waren technische Parameter wie Druckgeschwindigkeit und Auflösung nicht besonders wichtig, stattdessen fokussierte er auf die Einbettung der Geräte in das Dokumentenmanagementsystem. Während es früher in Ordnung war, zur technischen Leiterin in Jeans zu kommen, war es plötzlich wichtig, sich einem anderen Dresscode anzupassen. Vieles, womit sich die Mitarbeitenden vorher identifiziert hatten und was zu ihrem eigenen Selbstverständnis gehört hatte, zählte in der neuen Welt nicht mehr.

Beim Transformation Coaching ist es wichtig, dem Coachee (und/oder dem Team, der Führungskraft, der Organisation) zu helfen,

- sich bewusst zu werden, auf welche Erklärungsmuster, mentalen Modelle, Verhaltensweisen und Routinen sie gewohnheitsmäßig zurückgreifen. Bei den »Box Movern« war es vor allem die technische Affinität.

- die eigene Rollenidentifikation zu überdenken und bewusst anzupassen. Im Coaching mit den Führungskräften ging es darum, dass diese verstehen, wie Menschen tief greifende Veränderungen für sich erreichen können - bloße Informationen und Appelle wirken meist nicht tief greifend genug. 
- neue Erklärungsmuster und Verhaltensweisen auszuprobieren. In dem konkreten Fall arbeiteten die Führungskräfte in Teamsitzungen gezielt an neuen Gesprächs- und Präsentationstechniken mit den Mitarbeitenden.

- über die Zeit neue Gewohnheiten und Verhaltensmuster zu entwickeln. Hier halfen regelmäßige kollegiale Beratungen sowie Reflexions- und Austauschrunden mit den Führungskräften (Klimek \& AtKisson, 2016).

Manchmal liegt eine große Hürde für ein Unternehmen, in der VUKA-Welt erfolgreich zu sein, in ihrer Best Practice. Transformation Coaching kann unterstützen, nicht zu rigide an Erfolgen in der »alten « Welt festzuhalten, sondern die für die neuen Herausforderungen relevanten Erfolgsfaktoren zu identifizieren und sich systematisch neue Verhaltens- und Vorgehensweisen zu erarbeiten.

\section{Generative Coaching}

Das erste iPhone wurde 2007 vorgestellt und revolutionierte unsere Art der Kommunikation. Airbnb (2008) und Uber (2009) veränderten in kurzer Zeit die Reisegewohnheiten von Millionen. Mit Amazon (1994) hat sich das Einkaufsverhalten grundlegend gewandelt. Und das Agile Manifest (2001) und in der Folge Konzepte wie das agile Management oder beispielsweise Holacracy (2015) haben die Zusammenarbeit innerhalb von Organisationen und unser Verständnis von Macht und Hierarchie in Unternehmen deutlich verändert. Neuerungen dieser Art passierten nicht als kontinuierliche Verbesserung, sondern über ein radikales Neu-Denken und Neu-Machen (Robertson, 2016).

Transformationen können eingeleitet werden, wenn wir eine Ahnung vom Neuen haben - wenn wir sozusagen an der Schwelle zwischen Altem und Neuem stehen. Aber das Generieren von etwas gänzlich Neuem braucht einen eigenständigen Ansatz. Eine Organisation ahnt eventuell, dass alte Geschäftsmodelle und Geschäftspraktiken in der neuen, digitalen Welt nicht mehr weitertragen, sie besinnt sich auf ihre eigenen Stärken und Werte und wagt auf dieser Grundlage gleichsam einen Sprung in eine neue (Geschäfts-)Welt, wo neuartige Produkte und Dienstleistungen die Grundlage für komplett neue Geschäftsmodelle bilden. Diese Art von Sprung-Innovationen haben die oben erwähnten Unternehmen Apple, Uber und Airbnb usw. gewagt und gemeistert. Ähnliche Sprünge sind in der digitalen Arbeitswelt in vielen anderen Branchen und Anwendungsbereichen nötig. Wichtig ist, dass es den Unternehmen gelingt, die dafür notwendigen Ressourcen, die Kreativität und den Mut aufzubringen, um diese neuen Geschäftsmodelle und Ökosysteme zu entwickeln. Generative Coaching ist ein Ansatz, diesen Prozess hin zum Sprung in das 
neue Geschäftsmodell professionell vorzubereiten, zu ermöglichen und zu begleiten (Klimek, 2019a).

Das von Robert Dilts und Stephan Gilligan entwickelt Generative Coaching beginnt, wenn sowohl der Coachee - es kann sich dabei um eine einzelne Person handeln, um ein Team oder um eine Organisation (oder einen Teil einer Organisation) - als auch der Coach die Herausforderung verstanden haben und sich beide bewusst sind, dass sie noch keine Antworten auf diese Herausforderung kennen (Klimek, 2019a; Roth \& Ryba, 2016; Ryba \& Roth, 2019). Aus diesem Nichtwissen heraus versteht sich das Generative Coaching als ein Ansatz, der dem Coachee hilft, Zugang zu inneren Bewusstseinsräumen zu finden, in denen das Finden von Neuem leichter gelingt. Ein wesentlicher Erfolgsfaktor bei der Begleitung dieses Prozesses entsteht mit der gemeinsamen Etablierung eines »Performance State«. Wir alle kennen Momente und Situationen, in denen das Agieren in einer herausfordernden Situation besonders gut, leicht und flüssig gelingt oder in denen wir uns besonders kreativ und innovativ erleben. Einen bewussten Zugang dazu herstellen zu können, ist die Basis für das Entwickeln innovativer und disruptiver Ansätze. Die Kunst des Coaches besteht darin, dem Coachee zu helfen, sich immer wieder in den »Performance State« zu bringen, um sich daraus den Herausforderungen und möglichen Lösungen zu widmen. Sobald sich Wahrnehmung, Denken und Handlungsoptionen durch gewohnheitsmäßige innere Routinen zu sehr einengen, nutzt man im Generative Coaching zwei alternative Wege: Entweder man versucht den »Performance State« wiederherzustellen, oder aber man bearbeitet diese gewohnheitsmäßigen Routinen mit Ansätzen aus dem klassischen Coaching. Generative Coaching will den Boden systematisch vorbereiten, auf dem ein Aha-Erlebnis - ein Heureka - entstehen kann. Das Generative Coaching befähigt den Coachee (Individuum, Team, Führungskraft, Organisation), den Herausforderungen der komplexen VUKAWelt mit einer selbstbewussten kreativ-gestalterischen Kraft zu begegnen und so systematisch neue Chancen und (Geschäfts-)Vorteile für sich zu generieren.

An dieser Stelle verbinden sich die beiden Dimensionen »Form « und »Wirkung « von Coaching in Organisationen. Das Konzept der Coachingkultur beschreibt nicht nur den Rahmen, in dem Coaching in Organisationen zur Anwendung kommen kann, sondern gleichzeitig auch den Prozess, um Coaching für die konkreten Bedarfe der Organisation weiterzuentwickeln. Konkret könnte zum Beispiel der interne Pool an Coaches überprüft werden, inwieweit diese mit den Konzepten von Transformation Coaching und Generative Coaching vertraut sind, oder es könnten gezielt gewählte Projektteams, mit in diesen Methoden erfahrenen Coaches, bei der Bewältigung von VUKA-Herausforderungen unterstützt werden. 


\section{Fazit}

Die neuen Muster und Strukturen in der digitalen Wirtschaft ermöglichen eine sehr dezentrale und dynamische Organisation der Arbeit und der Geschäftstätigkeit. Dies führt zu vielfältigen, teilweise disruptiven Veränderungen - sowohl für die Mitarbeitenden als auch für die Unternehmen als Ganzes.

Eine Coachingkultur bereitet mehr oder weniger den Boden vor, auf dem das Coaching in einer Organisation gedeihen und sich verbreiten kann. Es ist sozusagen die Grundvoraussetzung, in dem Coaching zu einer organisationalen Realität wird. Aber ein erfolgreicher Coach und ein interessierter Coachee werden wenig Erfolg innerhalb einer Organisation haben können, wenn Coaching als Intervention für Low Performer stigmatisiert ist. Wenn aber ein Geschäftsführer offen über die Wichtigkeit seines eigenen Coachings in schwierigen Situationen redet, dann kann man davon ausgehen, dass sich Coaching als probates Mittel für den Umgang mit Herausforderungen innerhalb der Organisation leichter ausdehnen kann. Wenn auf einem solch fruchtbaren Boden die Erkenntnis in der Organisation reift, dass sie sich im Übergang von einer komplizierten hin zu einer komplexen Welt befindet und dass sie als Organisation agiler und resilienter werden muss, dann kann eine Coachingkultur den Rahmen und eine Werthaltung bilden, Transformation Coaching und Generative Coaching zu implementieren.

Die in diesem Beitrag vorgestellten Weiterentwicklungen des Coachings in Form des Transformation Coaching und des Generative Coaching geben Unternehmen Konzepte und Methoden an die Hand, die sie dabei unterstützen, die Herausforderungen der digitalen Transformation zu meistern. Eine organisatorisch verankerte Coachingkultur hilft Unternehmen, in der VUKA-Welt ihre grundsätzliche Handlungsfähigkeit zu erhalten. Sie können sich vor dem Hintergrund der neuen Herausforderungen besser behaupten und sind in der Lage, wichtige Entwicklungen für sich zu adaptieren. Der neue Ansatz des Transformation Coaching unterstützt darüber hinaus die gezielte Gestaltung einer umfassenden Transformation. Dieser Ansatz steht - auch mit seinem Namen stellvertretend für die Antwort des Coachings auf die Herausforderungen der digitalen Transformation. Der ebenfalls neue Ansatz des Generative Coaching geht an dieser Stelle bewusst noch weiter. Er führt eine neue Qualität der Beziehung zwischen Coach und Coachee ein und schafft die Voraussetzung für substanzielle und disruptive Innovationen. Generative Coaching steht für die systematische Suche nach neuen Chancen und Optionen, die sich durch die digitale Transformation ergeben. Der Ansatz hilft auf diese Weise, die Organisation zu befähigen, den neuen Kontext der VUKA-Welt für sich kreativ-gestalterisch zu nutzen und neue (Geschäfts-)Welten zu erschaffen. 


\section{Literatur}

Bonin, H., Gregory, T., Zierahn, U. (2015). Übertragung der Studie von Frey/Osborne (2013) auf Deutschland. Mannheim: Zentrum für Europäische Wirtschaftsforschung (ZEW). https://www. ssoar.info/ssoar/bitstream/handle/document/47125/ssoar-2015-bonin_et_al-Ubertragung_ der_Studie_von_FreyOsborne.pdf?sequence=1\&isAllowed=y\&lnkname=ssoar-2015-bonin et_al-Ubertragung_der_Studie_von_FreyOsborne.pdf [24.2.2020].

Clutterbuck, D., Megginson, D. (2009). Making Coaching Work - Creating a coaching culture. London: Chattered Institute of Personnel and Development.

Hawkins, P. (2012). Creating a Coaching Culture. Maidenhead: Open University Press.

Klimek, A. (2019a). Vom Coaching zur Coaching-Kultur - Der VUKA-Herausforderung begegnen. OrganisationsEntwicklung, 38 (3), 56-62.

Klimek, A. (2019b). Kollektives Umdenken - Neue Coachingansätze für die VUKA-Welt. managerSeminare, 255, Beilage- Special Coaching, 32-38.

Klimek, A., AtKisson, A. (2016). Parachuting Cats into Borneo and other Lessons from the Change Café. White River Junction, VT: Chelsea Green Publishing.

Klimek, A., Stork, W. (2018). Coaching-Kultur in deutschsprachigen Organisationen - das Konzept der resilienten und agilen Organisation. In R. Wegener, S. Deplazes, M. Hänseler, H. Künzli, S. Neumann, A. Ryter, W. Widulle (Hrsg.), Wirkung von Coaching. Göttingen: Vandenhoeck \& Ruprecht.

Laloux, F. (2015). Reinventing Organizations. Ein Leitfaden zur Gestaltung sinnstiftender Zusammenarbeit in Institutionen. München: Vahlen.

Landwehr-Zloch, S., Stork, W. (2019). Digitale Transformation. In A. Gemeinhardt (Hrsg.), Die Praxis der Gesellschaftswissenschaften. 30 Jahre Schader-Stiftung (S. 132-142). Darmstadt: Schader-Stiftung.

Robertson, B. (2016). Holacracy: Ein revolutionäres Management-System für eine volatile Welt. München: Vahlen.

Roth, G., Ryba, A. (2016). Coaching, Beratung und Gehirn. Stuttgart: Klett-Cotta.

Ryba, A., Roth, G. (2019). Coaching und Beratung in der Praxis. Stuttgart: Klett-Cotta. 


\section{Organisation modernisieren und Führung entwickeln}

Coaching für neue Führungskräfte im Kontext der Digitalisierung

Mathias Hofmann und Astrid Laudage

Die Verwaltung des Kreises Hameln-Pyrmont steht vor großen Herausforderungen, insbesondere im Zuge der Digitalisierung. Die Kreisverwaltung reagiert darauf mit gezielten Maßnahmen. Dazu gehört die systematische Förderung neuer Führungskräfte durch Coaching und die intensive Reflexion zu Führung und Zusammenarbeit in Führungstagen.

Das Coaching ist im Gesamtzusammenhang der Personal- und Organisationsentwicklung der Kreisverwaltung zu sehen und inhaltlich mit anderen Maßnahmen abzustimmen. Die Qualität des Coachings wurde durch eine Evaluation im Rahmen der Masterarbeit von Astrid Laudage (2018) bewertet. Diese zeigt eine als hoch wahrgenommene Unterstützung bei der Bewältigung von Herausforderungen im Führungsalltag der Coachees. Interessant ist, dass im Zusammenhang mit der Digitalisierung sowohl die Evaluationsergebnisse als auch die Erfahrungen während der Führungstage einen hohen Bedarf an analoger Kommunikation bei der Bewältigung der Digitalisierung nahelegen.

\section{Ausgangssituation}

Die Kreisverwaltung Hameln-Pyrmont ist eine zukunftsorientierte öffentliche Verwaltung im Weserbergland. Sie versteht sich als Dienstleisterin mit hoher Serviceorientierung für die rund 150000 Einwohner*innen, Unternehmen und Institutionen in den acht Städten und Gemeinden im Kreisgebiet und beschreibt sich als bürgernahe Verwaltung, die den Menschen in den Mittelpunkt ihrer Arbeit stellt (Landkreis Hameln-Pyrmont, 2017b, S. 2, 17 ff.).

Als großer Arbeitgeber stellt die Kreisbehörde durch ein im Jahr 2017 neu entwickeltes Personalkonzept 2020 (Landkreis Hameln-Pyrmont, 2016) auch ihre rund 650 Beschäftigten in den Mittelpunkt ihres Handelns. Ziele aus diesem Personalkonzept wurden im Personal- und Organisationsbericht 2017 
konkretisiert (Landkreis Hameln-Pyrmont, 2017a). Ein zentraler Handlungsauftrag laut diesem Konzept ist die Bereitstellung von ausreichend qualifiziertem Personal zur Sicherstellung einer funktionierenden Verwaltung. Bereits heute ist absehbar, dass 51 Prozent der heute Beschäftigten bis 2035 altersbedingt ausscheiden (Landkreis Hameln-Pyrmont, 2017a, S. 15 ff.). Ein Baustein zur Sicherstellung des zukünftigen Fach- und Führungskräftebedarfs ist die interne Personalentwicklung. Dabei wird ein aktueller Arbeitsschwerpunkt auf die Qualifizierung von Führungskräften gelegt, denen eine Schlüsselfunktion bei der Bewältigung von Zukunftsaufgaben zugesprochen wird (Landkreis HamelnPyrmont, 2017a, S. 22).

Neben der Personalentwicklung verfolgt die Kreisverwaltung seit 2017 auch die Entwicklung von Grundsätzen für Führung und Zusammenarbeit sowie einen sozialpartnerschaftlich angelegten Organisationsentwicklungsprozess, der auch das Thema »Digitalisierung« beinhaltet.

\section{Herausforderungen an Führung angesichts der Digitalisierung ${ }^{1}$}

Für die Kreisverwaltung Hameln-Pyrmont ist die Digitalisierung eine der großen aktuellen Herausforderungen und eine Chance für eine prosperierende Entwicklung des Landkreises. Die Kreisverwaltung hat daher als eine Säule dieses Veränderungsprozesses besondere Personalressourcen bereitgestellt, sogenannte Digitalisierungsgestalter mit der Aufgabe, eine Digitalisierungsstrategie zu entwickeln und den Digitalisierungsprozess transparent zu machen. Sie sollen die Kulturentwicklung und Mitarbeitendenbeteiligung gestalten, neue Prozesse definieren, digitale Online-Angebote auf den Weg bringen und interne Bildungsangebote koordinieren und konzipieren.

Einige interne Projekte sind bereits umgesetzt. So verfügt die Kreisverwaltung (Stand Ende 2018) zum Beispiel über ein Dokumentenmanagementsystem, einen verwaltungsweiten elektronischen Rechnungs-Workflow für Ein- und Ausgangsrechnungen, ein umfassendes Kreistags-Informationssystem, verschiedene Geoinformationssystem-Angebote, und Bürger*innen können in einzelnen Bereichen Online-Termine vereinbaren. Die Kreisverwaltung arbeitet eng mit der Hochschule und mit anderen Landkreisen als Smart-Region zusammen.

1 Der folgende Abschnitt nach einem Interview mit Andreas Pachnicke, Dezernent Zentrale Steuerung des Landkreises Hameln-Pyrmont am 16. Januar 2019 in Hameln; Niederschrift Mathias Hofmann. 
Die Digitalisierung ist nach dem Verständnis der Kreisverwaltung als umfassender Change-Prozess zu verstehen. Die Führungskräfte sind der Schlüssel für die Umsetzung und wichtig, um die Mitarbeitenden in diesem Veränderungsprozess mitzunehmen - auch um zu antizipieren, was die Digitalisierung für den jeweiligen Verantwortungsbereich bedeutet, gemeinsam mit den Mitarbeitenden die Herausforderungen vorauszusehen und bei ihnen notwendige Aktivitäten zu fördern. Während früher für Führungskräfte ein stärkerer Fokus auf Fachlichkeit gelegt wurde, ist heute die Mitarbeitendenführung und das Denken in veränderten Prozessen entscheidend.

Zwei Maßnahmen der Kreisverwaltung fokussieren explizit das Thema »Führung «: »Coaching für neue Führungskräfte« und »Entwicklung der Zusammenarbeit in einem gemeinsamen Führungsverständnis«.

\section{Coaching neuer Führungskräfte als strukturierte Personalentwicklungsmaßnahme}

Coaching etabliert sich laut Backhausen und Thommen (2017, S. VII) zunehmend als wichtiges Personalentwicklungsinstrument, um Menschen in Organisationen darin zu unterstützen, in einer sich wandelnden Arbeitswelt mit Unbekanntem umzugehen und situationsadäquate Lösungen zu entwickeln. Die beiden Autoren sehen aufgrund des schnellen und tief greifenden Wandels in der Arbeitswelt die Notwendigkeit, Beschäftigte zu befähigen, mit Veränderungen umzugehen und Problemlösungsfähigkeiten zu entwickeln, was eine hohe Reflexionskompetenz erfordert (Backhausen \& Thommen, 2017, S. 3). Scharmer (2014, S. 97) sieht hinsichtlich des Wandels in der Arbeitswelt insbesondere Führungskräfte gefordert, denen es gelingen muss, Prozesse in unvorhersehbaren Situationen zu gestalten, was kontinuierliche Lern- und Reflexionsbereitschaft voraussetzt. Diese Lern- und Reflexionskompetenz wird durch Coaching gefördert (Doppler, 1992, S. 38). Somit kann Coaching im Sinne von Personalentwicklung auch mit Blick auf zentrale Zukunftsanforderungen wie zum Beispiel der Digitalisierung wertvolle Unterstützung leisten.

\section{Die Konzeption des Landkreises Hameln-Pyrmont}

Die Personalabteilung unterstützt seit 2015 mit einer strukturierten Personalentwicklungsmaßnahme (Coaching und optional Trainings) Führungskräfte in den ersten zwölf Monaten bei der Aufnahme ihrer Führungstätigkeit, um sie 
unter anderem darin zu stärken, anstehende organisatorische Veränderungen zu bewältigen (Landkreis Hameln-Pyrmont, 2018, S. 2). Die Kreisverwaltung wünscht sich einen sicheren Auftritt in der Gestaltung der Herausforderungen angesichts der Digitalisierung einschließlich der Führung von Mitarbeiter ${ }^{\star}$ innen mit schwieriger Motivation hinsichtlich Veränderungen.

Der aktuelle (Standard-)Prozess ist in fünf Bausteine aufgeteilt (Landkreis Hameln-Pyrmont, 2018), er wird in Abbildung 1 dargestellt.

\begin{tabular}{|c|c|}
\hline Vorbereitungsaufgabe & $\begin{array}{l}\text { - Coachee formuliert eigene Ziele (teilweise mit Unterstützung durch den Coach) } \\
\text { - Coachee formuliert eigene Erwartungen an den Vorgesetzten } \\
\text { - Vorgesetzte Führungskraft fomuliert ebenfalls Entwicklungsziele für den Coachee }\end{array}$ \\
\hline Auftaktgespräch & $\begin{array}{l}\text { - Auftaktgespräch: Coach, Coachee, Führungskraft, Amtsleitung Personal und Organisation } \\
\text { - Abgleich von Zielen und Erwartungen } \\
\text { - Vereinbarung (schriftlich) von Entwicklungszielen für die Personalentwicklungsmaßnahme }\end{array}$ \\
\hline $\begin{array}{l}\text { Vorbereitung auf den } \\
\text { ersten Arbeitstag als neue } \\
\text { Führungskraft }\end{array}$ & $\begin{array}{l}\text { - Einzelcoaching } \\
\text { - Vorbereitung auf neue Rolle/neue Aufgabe } \\
\text { - Vorbereitung auf neues Team/neues Amt }\end{array}$ \\
\hline $\begin{array}{l}\text { Bearbeitung individueller } \\
\text { Fragestellungen }\end{array}$ & $\begin{array}{l}\text { - Einzel-Coaching, z.B. Herausforderungen im Führungsalltag } \\
\text { - weitere individuelle Fragestellungen } \\
\text { - Berücksichtigung von vereinbarten Personalentwicklungszielen laut Auftaktgespräch }\end{array}$ \\
\hline $\begin{array}{l}\text { Abschlussgespräch } \\
\text { Coaching }\end{array}$ & $\begin{array}{l}\text { - Zwischengespräch im Rahmen der Personalentwicklungsmaßnahme } \\
\text { - Ableitung möglicher weiterführender Entwicklungs- und Unterstützungsbedarfe } \\
\text { - Teilnehmer: Coachee, Coach, Führungskraft, Amtsleitung Personal und Organisation }\end{array}$ \\
\hline
\end{tabular}

Abbildung 1: Bausteine der Coachings (eigene Darstellung in Abstimmung mit der Personalabteilung)

Dass Coaching eine derart zentrale Rolle spielt, entspricht damit der auch in der Literatur belegten Tendenz, Coaching als grundlegende Unterstützung neuer Führungskräfte einzusetzen (s. o.).

\section{Das konkrete Coachingkonzept}

Mit der Umsetzung betraut wurden externe Coaches einer Unternehmensberatung, die den Landkreis auch bei Führungstagen und bei Team- und Organisationsentwicklung berät. Diese Unternehmensberatung versteht Coaching sowohl als Unterstützung der einzelnen Personen in ihrer neuen Rolle wie auch als Teil der Organisationsentwicklungsmaßnahme des Landkreises (vgl. »Komplementär-Coaching «, Strikker, 2007). Coaching im Business-Kontext dient allgemein der Verbesserung der persönlichen beruflichen Situation, sei es hinsichtlich der Positionierung und Kompetenzentwicklung, sei es bei der Lösung von spezifischen Fragestellungen und der Entscheidungsfindung, dies im Rah- 
men der organisationalen Ziele - hier insbesondere Veränderungskompetenz und Digitalisierung -, die von der Führungskraft wesentlich beeinflusst werden sollen.

Intention, Ziel, Zeitplanung, Vorgehensweise und Ressourceneinsatz werden daher gemeinsam zwischen Coach, Coachee, der jeweiligen Führungskraft und einem Vertreter der Personalabteilung vereinbart (Klein \& Strikker, 2003). Dabei fließen individuelle Vorstellungen des Coachee und die systemischen, organisatorischen Rahmenbedingungen der Führungskraft und der Personalabteilung in die Vereinbarung mit ein. Die besonderen aktuellen Herausforderungen in der Organisation, zum Beispiel durch die Digitalisierung, werden mit Blick auf die Handlungsanforderungen an die Coachees bearbeitet.

Die Methoden im Coaching sind vielfältig: Feedback und Selbstreflexion sind immer wesentliche Bestandteile. Weitere Elemente sind die gemeinsame Entwicklung von Lösungsoptionen und Entscheidungskriterien. Übungselemente bis hin zu Rollenübungen und Video werden anlassbezogen eingesetzt. Der Transfer wird über die Zusammenfassung aus Sicht des Coachee und Aufgabenstellungen bis zum nächsten Coaching mit anschließender Reflexion erreicht. Das Format ist in aller Regel das persönliche Gespräch in einem Besprechungsraum mit Moderationsmaterial/Beamer. Telefon- oder Video-Coaching und Mailings zwischen Coach und Coachee werden angeboten, aber nach Auskunft der Coaches selten genutzt (die Kundinnen sind für die Coaches leicht erreichbar). Verabredungen über E-Mail und die Dokumentation in digitaler Form sind natürlich Bürostandards.

Zum Abschluss des Prozesses bewerten entsprechend Coach, Coachee, Vorgesetzte und Vertreter der Personalabteilung gemeinsam die Entwicklung und entscheiden weitere Schritte der Personalentwicklung und Zusammenarbeit in der Führung. Die Personalleitung gewährleistet die Standardisierung und direkte weitere Umsetzung.

Die eingesetzten externen Coaches bringen in Absprache mit der Personalabteilung der Kreisverwaltung Hameln-Pyrmont neben den formulierten konkreten Themen und Fragestellungen der Coachees und ihrer Führungskräfte einen allgemeinen Themenkanon für neue Führungskräfte mit dem Fokus auf Veränderungsmanagement und Digitalisierung ein. Es sind dies: Rolle der Führungskraft, Kommunikation und Zusammenarbeit, Gespräche mit einzelnen Mitarbeitenden, Teamführung und Change-Management. Die Themen bearbeiten Coach und Coachee anlass- und fallbezogen. Die vermittelten Modelle und Theorien aus der humanistischen Psychologie und der Betriebswirtschaftslehre stimmen die Coaches untereinander ab. Die Arbeit in Coachings wird über Flipchart visualisiert, eine Fotodokumentation jeweils den Coachees zeitnah digital zur Verfügung gestellt. 


\section{Die Evaluation: Konzept, Durchführung, Ergebnisse}

Zur Qualitätssicherung und als Weiterentwicklungsgrundlage von Personalentwicklungsmaßnahmen gehört es, die Maßnahmen zu überprüfen (Ryschka, Solga \& Mattenklott, 2011, S. 369). Die Coachings wurden daher im Rahmen einer Masterarbeit im Jahr 2018 wissenschaftlich evaluiert.

Als theoretischer Evaluationsrahmen dienten die Qualitätsdimensionen (Struktur-, Prozess- und Ergebnisqualität) von Heß und Roth (2001, S. 10 ff.), die auf die Nutzerperspektive übertragen wurden. Diese zielt auf das Qualitätsverständnis im Sinne von »fitness for use« nach Juran (1991) ab. Juran schlägt vor, Qualität unter dem Aspekt der Gebrauchstauglichkeit einer Leistung und individueller Kundenbedürfnisse zu beurteilen (vgl. Wirtschaftslexikon.co, 2015).

Eine Kernfrage der Evaluation war: Wie bewerten Coachees das Coaching, und welche Bausteine aus den Coachings nehmen sie als Unterstützung für eine neue Führungsaufgabe wahr? Der Arbeit lag dabei unter anderem folgende Annahme zugrunde: Coaching unterstützt Führungshandeln in der Praxis.

Die Evaluation fand auf Basis eines selbst gestalteten Onlinefragebogens als rückblickende Betrachtung bisher durchgeführter Coachings statt. Die technische Umsetzungsunterstützung erfolgte durch das in der Organisation vorhandene Befragungstool (»LimeSurvey«), die Auswertung der Ursprungsdaten mithilfe von SPSS.

Der Fragebogen bestand aus 32 Fragen und beinhaltete einen Fragenmix aus geschlossenen Fragen mit und ohne Freitextfeld, Auswahlantworten mit Rangordnung/Alternativvorgaben, Filterfragen, Mehrfachnennungen, offenen Fragen sowie freiwilligen Angaben, zum Beispiel zu Führungs- und Coachingvorerfahrungen.

Befragt wurden alle achtzehn neuen Führungskräfte, die seit Maßnahmenbeginn Ende 2015 an der Personalentwicklungsmaßnahme teilgenommen haben oder damit gestartet sind. Der Kreis der Teilnehmenden bestand also aus Coachees, die die Coachings abgeschlossen hatten oder sich noch im Coachingprozess befanden. Bei der Befragungsauswertung konnte kein Ergebnisunterschied zwischen abgeschlossener und nicht abgeschlossener Personalentwicklungsmaßnahme festgestellt werden.

Heterogenität bestand laut Rückmeldungen in den (freiwilligen) Angaben auch hinsichtlich Führungsvorerfahrungen: Sechs der neuen Führungskräfte verfügten über Führungsvorerfahrungen, die gleiche Anzahl verneinte dies. Zwei Teilnehmende machten dazu keine Angaben. 
Die Ergebnisauswertung basiert auf vierzehn von achtzehn abschließend bearbeiteten Fragebögen, was einer Rücklaufquote von rund 78 Prozent entspricht. Zu allen Fragen wurden deskriptive Statistiken erstellt. Die Antworten auf die offenen Fragen wurden in Anlehnung an die Inhaltsanalyse (Mayring, 2016, S. $114 \mathrm{ff}$.) ausgewertet.

Die Bewertung der Coachings aus Perspektive der Coachees sahen nun folgendermaßen aus:

Strukturqualität: hundertprozentige Zufriedenheit mit Auswahl und Zuordnung des Coaches durch die Personalabteilung.

- Die Verwaltung als Coachingort ist geeignet (86\%).

- Externe Coaches mit Verwaltungserfahrung werden als sehr wichtig (71\%) bzw. als wichtig (21\%) erachtet.

Prozessqualität: Der aktuelle Prozess wird als zielführend und passend bewertet.

- 89 Prozent der Teilnehmenden nahmen durch die Einbindung der vorgesetzten Führungskraft in den Prozess eine Unterstützung wahr.

- Einzelcoaching wird ausnahmslos als herausragend wichtiger Baustein der Personalentwicklungsmaßnahme bezeichnet (100\%).

- Personalentwicklungsmaßnahmen ohne Coachings wird geringer $(86 \%)$ bis keinerlei Stellenwert (7\%) zugesprochen.

- Coachings als Vorbereitung auf den ersten Tag in der neuen Rolle ist für neue Führungskräfte mit Führungsvorerfahrung besonders wichtig.

- Die Bearbeitung individueller Fragestellungen zum Führungsalltag war für 93 Prozent bedeutend.

Ergebnisqualität: Große Zufriedenheit mit den Einzelcoachings.

- Einzelcoaching gilt als »effektivstes Mittel« (Originalaussage); die subjektiv wahrgenommene Ergebniszufriedenheit ist hoch (94\%).

- Bearbeitung individueller Fragen zum Führungsalltag hat im Coaching unabhängig von Führungsvorerfahrung einen hohen Stellenwert (97\%).

- Coaching fördert die Entwicklung von eigenen Lösungen (93\%).

- Sicherheit bei der Rollenfindung wird unabhängig von Führungsvorerfahrungen als bedeutend angesehen (100\%).

- Hervorgehoben werden individuelle Lerneffekte sowohl in theoretischer als auch in praktischer Hinsicht.

Gesamtfazit der Teilnehmer: Coaching wird, unabhängig von Führungsvorerfahrung, als wichtigster Baustein der Personalentwicklungsmaßnahme 
und als wertvolle Unterstützung bei der Bewältigung von Führungsaufgaben wahrgenommen (93\%) (Originalaussage: »unerlässliche Vorbereitung auf die zukünftigen Führungsaufgaben«).

Die Teilnehmenden empfehlen den Zugang zum Coaching für einen erweiterten Personenkreis und den Ausbau des Coachingangebotes auch über die ersten zwölf Monate der neuen Führungsaufgabe hinaus.

Die wichtigsten Resultate der Evaluation sind damit: Eine persönliche Begleitung bei einem neuen Führungsauftrag wird als enorm wichtig angesehen. Die Unterstützungsleistung durch Coaching wird unabhängig von Führungsvorerfahrung als sehr hoch bewertet und insbesondere bei aktuellen Entwicklungen im Führungsalltag als wichtig angesehen. Eine Ergänzung des Coachingangebotes durch Mentorate wird gewünscht. Die Personalentwicklungsmaßnahme erhält durch Coachingbausteine einen besonders hohen Stellenwert. Coaching fördert Sicherheit im Führungshandeln und unterstützt bei der Bearbeitung aktueller Themen aus dem Führungsalltag.

\section{Fazit und Ausblick}

Die Befragungsergebnisse sind ein Hinweis dafür, dass die Coachingbausteine im Rahmen dieser Personalentwicklungsmaßnahme als zielführend gestaltet und als wichtige Unterstützung beim Hineinwachsen in die neue Führungsrolle sowie bei der Bearbeitung individueller Fragestellungen aus dem Führungsalltag wahrgenommen werden. Die positive Bewertung der Coachings ist auch als grundsätzlich positive Rückmeldung der neuen Führungskräfte an Personalamt und Verwaltungsspitze zu sehen, die mit der Einführung dieser Personalentwicklungsmaßnahme die relevanten Akzente gesetzt haben, Führungskräfte bei der Ausübung ihres Führungsauftrages situations- und anlassbezogen zu unterstützen und zu stärken. In der Verbindung mit den Führungstagen praktizieren sie bereichsübergreifendes Denken und Zusammenarbeit. Auch das Detail der gemeinsamen Zielformulierung und Auswertung für die Coachingmaßnahme durch Coachee, Führungskraft und Personalabteilung verbindet die diversen Sichtweisen auf die besonderen Herausforderungen angesichts der Digitalisierung und Modernisierung der Verwaltung. Die Ausrichtung auf Projekte und entsprechende Gestaltung der internen Fortbildung ist ebenso ein weiterer Baustein wie die aktive Gestaltung von Führungsgrundsätzen und die Weiterentwicklung der Kommunikation in der Verwaltung. Hier werden neue analoge Formate (Führungswerkstatt, Mittagsjournal) eingesetzt, aber auch digitale Formate (Videobotschaft, Chat-Tool, Forum im Intranet). Als weiteren 
positiven Effekt in der Organisation nennen die Verantwortlichen des Personalamts ein zunehmendes Interesse der Mitarbeiter ${ }^{*}$ innen, Führungspositionen einzunehmen; positiv haben sich die Maßnahmen aber auch auf die externe Personalbeschaffung im Bereich Führungskräfte ausgewirkt.

Einschränkend ist zu bemerken, dass die subjektiven Rückmeldungen der gecoachten Führungskräfte und der beauftragenden Personalabteilung nur bedingt Rückschlüsse erlauben, inwieweit die Kreisverwaltung Hameln-Pyrmont die Veränderung angesichts der Digitalisierung tatsächlich besser bewältigen kann als ohne die Coachingmaßnahmen. Digitalisierung war nicht explizit Gegenstand der Evaluation. Eine offensive Ergänzung der analogen Coachings durch digitale Formate - zum Beispiel durch eine Coachingsitzung im Videoformat als Standard und mehr digitale Elemente (Learning Nuggets) einschließlich der Reflexion dieser Arbeitsweisen für die Führungskraft - wäre hier wohl eine angemessene Weiterentwicklung, die in der Tat inzwischen auch da und dort schon realisiert wird.

\section{Literatur}

Backhausen, W., Thommen, J.-P. (2017). Coaching. Durch systemisches Denken zu innovativer Personalentwicklung (4., aktualisierte Auflage). Wiesbaden: Springer Gabler.

Doppler, K. (1992). Coaching, Mode oder Notwendigkeit: Was und wie ein Coach wirklich sein sollte. Gablers Magazin, 4, 36-41.

Heß, T., Roth, W. (2001). Professionelles Coaching. Eine Expertenbefragung zur Qualitätseinschätzung und -entwicklung. Heidelberg: Asanger.

Juran, J. M. (1991). Handbuch der Qualitätsplanung. Landsberg am Lech: Moderne Industrie.

Klein, S., Strikker, H. (2003). Auftragscoaching oder die Tücken der Dreiecksbeziehung. Bonn: Managerseminare Verlag.

Landkreis Hameln-Pyrmont (2016). Personalkonzept 2020. Unveröffentlichtes Dokument.

Landkreis Hameln-Pyrmont (2017a). Personal- und Organisationsbericht 2017. Unveröffentlichtes Dokument.

Landkreis Hameln-Pyrmont (2017b). Zahlen, Daten, Fakten. Landkreis Hameln-Pyrmont im Überblick. Unveröffentlichtes Dokument. https://www.hameln-pyrmont.de/media/custom/ 2749_1282_1.PDF?1498029190 [4.7.2018].

Landkreis Hameln-Pyrmont (2018). Personalarbeit mit Konzept. Personalentwicklung für Führungskräfte. Hameln. Unveröffentlichtes Dokument.

Laudage, A. (2018). Evaluation von Coachings als Baustein einer Personalentwicklungsmaßnahme. Unveröffentlichte Masterarbeit, EURO-FH, Hamburg.

Mayring, P. (2016). Einführung in die Sozialforschung. Weinheim: Beltz.

Ryschka, J., Solga, M., Mattenklott, A. (Hrsg.) (2011). Praxishandbuch Personalentwicklung. Instrumente, Konzepte, Beispiele (3., vollständig überarbeitete und erweiterte Auflage). Wiesbaden: Gabler.

Scharmer, C. O. (2014). Theorie U - Von der Zukunft her führen (4. Auflage). Heidelberg: Carl-AuerVerlag. 
Strikker, H. (2007). Komplementär-Coaching, Mensch und System komplementär verbinden. Paderborn: Junfermann.

Wirtschaftslexikon.co (2015). »Qualität«. www.wirtschaftslexikon.co/d/qualitaet/qualitaet.htm [17.8.2018]. 


\title{
Digitaler Wandel - Möglichkeiten einer erfolgreichen Transformation
}

\author{
Elke Benning-Rohnke, Joachim Hasebrook und Marco Schärer
}

„Wenn etwas digitalisiert werden kann, wird es auch digitalisiert werden« der Satz ist so aktuell wie 2000, als inn Carly Fiorina, die ehemalige Chefin von Hewlett-Packard, formulierte. Tatsächlich führen die neuen, digitalen Möglichkeiten überall zu veränderter Leistungserbringung und damit zu neuen Rollen und Verantwortlichkeiten. Oft ist mit dem Einzug der neuen Möglichkeiten der Wunsch nach mehr Agilität der Organisation verbunden.

Bisherige Ansätze konzentrieren sich auf teils aufwendige Veränderungsprogramme mit umfassenden Reorganisationen und Kommunikations- und Trainingsmaßnahmen. Der gewünschte Produktivitätsschub bleibt jedoch oft aus.

Die in diesem Beitrag dargestellte, praxiserprobte Vorgehensweise basiert auf Erkenntnissen der Psychologie und Coachingforschung. Nach dem Motto »Freedom within Frames« werden zentrale Stellhebel des Erfolges ॥top-down« vorgegeben. Die Umsetzung hingegen wird in den jeweiligen Teams entschieden und in einem Prozess mit den Phasen »Reflexion«, "Ambition« und »Volition« begleitet. So führen digitale Neuerungen »bottom-up« selbstbestimmt zu neuen, produktiven Arbeitsabläufen, und gleichzeitig wird eine Kultur von mehr Selbstverantwortung und Gestaltung positiv erfahrbar gemacht. Führungskräfte sind eng und verantwortlich eingebunden und bauen ihre Führungswirksamkeit entsprechend den neuen Anforderungen aus.

Am Beispiel einer führenden Regionalbankgruppe zeigen wir die beeindruckenden Effekte auf Akzeptanz, Weiterempfehlung (Net Promoter Score, NPS), Kompetenzzuwachs und Aktivitätskennziffern (z. B. Anzahl Termine, Abschlüsse, Einsatz von Tools) und Ergebniskennziffern, darunter Umsatzwachstum und Rentabilität. Das Vorgehen wurde bereits auf andere Kunden und andere Herausforderungen erfolgreich übertragen. 


\section{Freedom within Frames - das Konzept}

"Wenn etwas digitalisiert werden kann, wird es auch digitalisiert werden «: Auch für Finanzintermediäre bedeutet dies, dass sie ihre wesentlichen Transformationsfunktionen darauf überprüfen müssen, was passiert, wenn alles, was digitalisiert werden kann, tatsächlich digitalisiert ist (Linder \& Cantrell, 2000). Alle digitalisierbaren Dienstleistungen, nicht nur bei Finanzdienstleistern, ändern sich derzeit nach dem 4-P-Prinzip: partizipativ, prädiktiv, präventiv und personalisiert. Dies bedeutet, dass Kund ${ }^{\star}$ innen aktiv an der Entstehung von Produkten und Diensten (sogenannt »hybriden « Dienstleistungen; vgl. Soulami, 2014) teilhaben (partizipativ), Dienste vorhersehen, wann wo welcher Bedarf entsteht (prädiktiv), und Dienstleistungen daher schon angeboten werden können, bevor der Kunde selbst den Bedarf erkennt (präventiv). Die so entstehenden Angebote leben dabei nicht nur von Skaleneffekten nach dem Motto »One size fits all«, sondern von zielgenauer Personalisierung und Interaktionen (personalisiert; vgl. Schaap, 2014).

Die neuen Möglichkeiten führen überall zu veränderter Leistungserbringung und damit zunächst zu Unsicherheit und Unklarheit in Rollen und Verantwortlichkeiten. Neue Aufgaben im digitalen Umfeld erfordern zudem häufig ein Re- oder Up-Skilling. Darüber hinaus ist mit dem Einzug der neuen digitalen Möglichkeiten oft auch der Wunsch nach mehr Agilität der Organisation verbunden (z. B. Katayama \& Bennett, 1999). Klassisch geprägte und langjährig gewachsene hierarchische Strukturen sollen weichen und Platz schaffen für Partizipation und Mitspracherecht der Mitarbeitenden. Auch das sind nach langen Zeiten von Command und Control harte Änderungsanforderungen in Haltung und Verhalten für Führungskräfte und Mitarbeiter.

Zur Durchsetzung der neuen Vorgaben greift der Vorstand mit typischen "Managementmaßnahmen« in die Struktur ein: Zuständigkeiten werden verändert, Aufgaben und Kundengruppen neu segmentiert und zugeordnet, Zielsetzungen noch engmaschiger und kleinteiliger vorgegeben und kontrolliert. $\mathrm{Zu}$ einem »Motivationsschub « sollen vor allem Unternehmensveranstaltungen, Schulungen und materielle Anreize führen. Das Ergebnis von mehr Steuerung, mehr Vorgabe und mehr Verhaltenskontrolle führt aber zu keiner spürbaren Wirkung, oftmals fühlen sich die Mitarbeitenden zunehmend entmündigt und entmutigt.

Solche Ansätze konzentrieren sich also auf aufwendige Veränderungsprogramme mit umfassenden Reorganisationen, Kommunikations- und Trainingsmaßnahmen, um den Mitarbeitenden die Unternehmensziele zu vermitteln und sie zu deren Umsetzung zu motivieren. Doch solche Programme zeigen häufig nicht die gewünschte Wirkung, weil zwar das Topmanagement die 
Veränderung will, die Mitarbeitenden sie jedoch scheuen. Mehr noch: Gerade die durch digitale Transformation ausgelösten fundamentalen Umwälzungen und zahllosen technologischen Veränderungen schaffen Unsicherheit und Unübersichtlichkeit der zahllosen Optionen, Chancen und Risiken (vgl. ITU-T Focus Group, 2016). Vermeidungstaktiken, wie Leugnen des Veränderungsbedarfs und Abwertung des Neuen, kommen ins Spiel, die vom Management geforderte Veränderungsumsetzung bleibt in der sogenannten »Angstzone» stecken (siehe Abbildung 1, zweiter Kreis von links; vgl. auch Gollwitzer, Kuhl \& Heckhausen, 1996; Gollwitzer \& Sheeran, 2006).

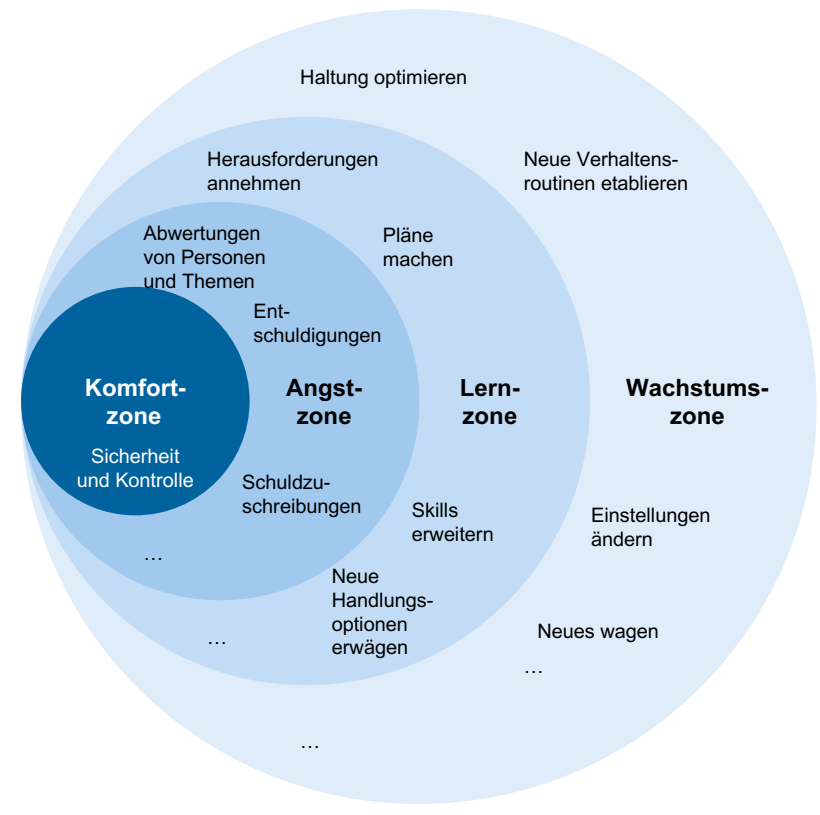

Quelle: zeb Projekterfahrung

Abbildung 1: Angst-/Lern-/Wachstumszone

Die zentrale Frage lautet also: Wie kann es gelingen, Mitarbeiter*innen und Führungskräfte so in die Lern- und Wachstumszone zu entwickeln, dass die Möglichkeiten der Digitalisierung genutzt werden und die gewünschte Kulturveränderung im Miteinander erfolgreich und nachhaltig gelebt wird?

Herangehensweisen nach dem Motto »Freedom within Frames« sind hier eine gute Antwort. Zentrale Leitplanken und Zielsetzungen des Unternehmens bleiben zunächst unverändert, die Umsetzung wird jedoch in den Teams entschieden. So führen digitale Neuerungen bottom-up und selbstbestimmt zu neuen Arbeitsabläufen, gleichzeitig wird eine Kultur von mehr Flexibilität, mehr Selbstbestimmtheit, mehr Partizipation positiv erfahrbar gemacht. 
Das Vorgehen »Freedom within Frames« berücksichtigt im Gegensatz zum Einzelcoaching die Anforderungen der Organisation als ein Mehrebenensystem (vgl. Greif, 2013). Hierarchisch übergeordnete Ebenen geben die Stellhebel des Erfolges als Frames vor. Die Arbeit des Coaches konzentriert sich dann auf die umsetzenden Teams. Der Coach begleitet das ganze Team einschließlich der Führungskraft in einem Prozess von »Reflexion «, »Ambition « und »Verstetigung « in der bestmöglichen Umsetzung (Freedom) innerhalb der gesetzten Frames. Teamorientierte Methoden und auf das Individuum bezogene Reflexionen und Coachings ergänzen sich. So werden neben der Entwicklung individueller Stärken auch Beziehungsdynamiken zwischen Mitarbeitenden und Führungskraft sowie Beziehungsdynamiken im Team berücksichtigt und verbessert. Zudem ist der Coach nicht wie im klassischen Einzelcoaching in der Coach-Coachee-Wahrnehmung begrenzt, sondern erfährt die erlebte Arbeitswirklichkeit, Hürden und Treiber der Veränderung aus vielen Perspektiven. Das stärkt seine Rolle als Moderator, Inputgeber und Sparringpartner. Zum Erfolg trägt zudem bei, dass jeder im Team die Veränderung selbst aktiv gestaltet. So werden die neu entwickelten Einstellungen und Verhaltensweisen schnell als neue Normalität von allen akzeptiert und gelebt. Die Nachhaltigkeit und eine weitere Entwicklung der Teams in der Lern- und Wachstumszone werden durch einen Transfer der verwendeten Methoden vom Coach auf die Führungskraft gesichert. In der Praxis geben mehr als 80 Prozent der Führungskräfte an, mit den im Programm gelernten Vorgehen und Methoden weiterzuarbeiten.

Die verwendeten Methoden können mit wenig Aufwand auch auf unternehmensinterne Coaches übertragen werden. Das Vorgehen in dem Programm eignet sich für unterschiedlichste Veränderungsvorhaben. Wesentlich ist, die Stellhebel des Erfolgs identifiziert zu haben - die Frames. Der Weg bleibt in der Freiheit (Freedom) der Teams (siehe Abbildung 2; vgl. dazu Gollwitzer, Kuhl \& Heckhausen, 1996).

Durch den so erweiterten Gestaltungsraum des Einzelnen wird die Notwendigkeit, Veränderungen als Konstante im Arbeitsalltag zu integrieren, Veränderung wird gelebte Routine, gewinnt Kopf und Herz und kann beliebig weitergeführt werden. Auf das positive Erleben in Kopf und Herz kommt es an, wenn die Organisation sich schnell und reibungslos transformieren soll. Das kann der Mensch, denn er hat sich historisch schon immer transformiert. Die Aufgabe von Führungskräften besteht darin, ein Umfeld zu schaffen, das viele Mitarbeiter durch positives Erleben zu einem Teil und Treiber der digitalen Evolution im Unternehmen macht. Dafür brauchen sie ein geeignetes methodisches Vorgehen (vgl. Volkens \& Anderson, 2018). 


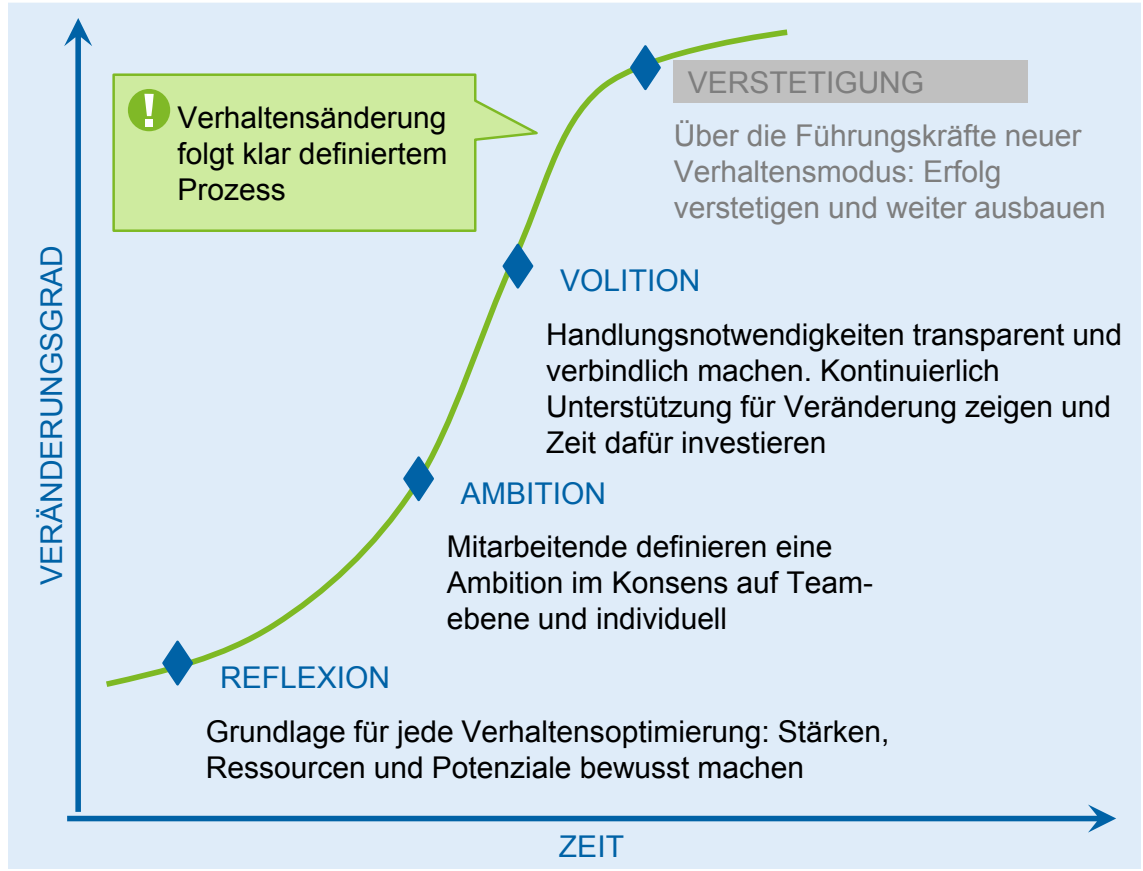

Abbildung 2: Phasen der Verhaltensänderungen von Individuen in Teams

\section{Management by Ambition - die Erfolgsparameter}

Zwar müssen Strategievorgaben "führungsgetrieben" sein, doch ihre Umsetzung muss "willensgetrieben« sein: Jede Mitarbeiterin, jeder Mitarbeiter muss den eigenen Beitrag zur Umsetzung erkennen und leisten wollen. Nur so entfaltet sich die Kraft von vielen, und die Veränderung wird gelebte Realität. Damit stellt sich aber automatisch die Frage: Wenn jeder und jede Mitarbeitende tut, was er oder sie will, wie kann der Prozess so gesteuert werden, dass er zu dem vom Management gewünschten Ziel führt? Die Antwort lautet: Die Aktivierung des Umsetzungswillens muss ein transparenter und nachvollziehbarer Prozess sein. Die Begleitung eines erfahrenen Coaches als Anleiter und Moderator ist zu Beginn sehr empfehlenswert, um Widerstände abzubauen und Individuen und Teams schnell in die Lern- und Wachstumsphase zu führen. Die Führungskräfte steuern und managen den Prozess und lernen dabei selbst neue Methoden der Führung. Führungskräfte bleiben der Vertrauensanker für die Teams insbesondere für die Anforderungen einer 
»digitalen Transformation «, für die niemand stabile Zukunftsszenarien und daraus abgeleitete Organisationsleitlinien anbieten kann (vgl. etventure \& GfK, 2018). Die Evaluationen, die unsere Arbeit beim Kunden begleiten, zeigen, welche Komponenten umfassender Veränderungs- und Umsetzungsprozesse unabhängig vom eingesetzten Personal vom Geschäftsmodell und von der aktuellen wirtschaftlichen Lage des Unternehmens zu messbar höherem Geschäftserfolg führen (vgl. Benning-Rohnke \& Hasebrook, 2018). Neu sind dabei die folgenden Aspekte:

1. Perspektivenwechsel: Aus »Management by Objectives $(\mathrm{MbO})$ wird »Management by Ambition « (MbA), weil Unternehmensziele nicht mehr vorgegeben und vereinbart werden, sondern Mitarbeitende im Team so geführt werden, dass sie selbstständig ein ausreichendes Ambitionsniveau und hohen Umsetzungswillen (Volition) entwickeln. Das Vorgehen ist nicht personenabhängig, sondern kann sowohl von internen als auch von externen Coaches erfolgreich umgesetzt werden.

2. Nachweis der Wirksamkeit: Die Wirksamkeit von Veränderungsprogrammen ist aufgrund der Vielzahl von Einflussfaktoren oft kaum kausal zu belegen. Unsere mehrjährigen Evaluationen belegen nachvollziehbar die Wirksamkeit unseres Umsetzungsprozesses auf den Ebenen Akzeptanz und Kompetenzzuwachs, die wir mittels eines anonymen Online-Fragebogens und mithilfe von Aktivitäts- und Ergebniskennziffern erhoben haben (Benning-Rohnke \& Hasebrook, 2018). Zu Letzteren wurden Tausende von Kund ${ }^{\star}$ innen in begleiteten Geschäftseinheiten sehr ähnlichen Kundenprofilen in untrainierten Einheiten gegenübergestellt; Wirkungen zeigen sich sowohl auf der Ebene von Mitarbeitendenaktivitäten als auch in den Erfolgskennziffern (»Key Performance Indicators«, KPI) zur Geschäftsentwicklung.

3. Stabilität: Die Wirksamkeit unseres Ansatzes ist unabhängig von wirtschaftlicher Lage, Strategiewechseln und dem eingesetzten Personal (Mitarbeitende, Führungskräfte, Coaches) über einen Zeitraum von über sechs Jahren und bei mehr als viertausend trainierten Mitarbeiter*innen und Führungskräften nachweisbar.

4. Integration: Unser Ansatz hebt die unsinnige Trennung in Change Management, Führungskräfteentwicklung und Vertriebstraining auf, indem eigentlich seit Jahren bekannte psychologische Grundlagen zur Entwicklung von Ambition, Volition und Reflexion konsequent auf die Unternehmensentwicklung angewendet werden.

Damit steht ein strukturiertes Vorgehensmodell zur Verfügung, das unabhängig von Inhalt und Branche eingesetzt werden kann, vom Management beherrsch- 
bar ist und den Kompetenzübertrag von externen Beratern oder Trainern auf das durchführende Unternehmen sicherstellt.

\section{Methodisches Vorgehen}

Die Einführung von mehr Engagement, mehr Partizipation und mehr Flexibilität im Denken und Handeln ist eine Managementaufgabe. Es geht um die Veränderung von Einstellungen und Verhalten von Individuen/Teams, die im Ergebnis zu der gewünschten neuen Unternehmens- und Arbeitskultur führt. Beratungsinhalte von Coaching und Supervision sind dafür entscheidend.

1. Reflexion: In der Reflexionsphase geht es um ein individuelles und später gemeinsames Verständnis der Ist-Situation und ihrer Möglichkeiten und Herausforderungen als Ausgangspunkt einer erfolgreichen Veränderungsdynamik. In unserem Vorgehen besteht diese Phase aus halbstündigen strukturierten Dialogen mit jedem einzelnen beteiligten Individuum - sowohl Mitarbeitende als auch Führungskräfte umfassend. Da jede Transformation ein partizipativer Prozess sein muss, werden die Meinungen und subjektiven Wahrnehmungen der betroffenen Teammitglieder eingeholt. Jeder schildert seine Wahrnehmungen und Einschätzungen und entwickelt Lösungsansätze. Derart beginnt ein Reflexionsprozess und eine Identifizierung mit möglichen Lösungen. Die unterschiedlichen Perspektiven sind für den Coach wie für die Führungskraft von immenser Bedeutung. Sie geben zusammen mit faktischen Informationen ein deutliches Bild der Stärken und Schwächen sowie Auskunft über verborgene Konflikte und Potenziale. Anders als in herkömmlichen Coachingsituationen, in denen der Coach oft in der Wahrnehmungswelt seines Coachee gefangen ist, erhält er in unserer Vorgehensweise umfassende Informationen aus unterschiedlichen Perspektiven und kann sich so ein differenziertes Bild über den Kontext und die Veränderungsanforderungen schaffen. In einem zusätzlichen Gespräch mit den Führungskräften bereitet der Coach die Führungskraft auf ihre Rolle im folgenden Transformationsprozess vor. Zudem definiert der Coach mit der Führungskraft potenzielle Stellhebel des zukünftigen Erfolgs. Das ist aus unserer Sicht essenziell für Erfolg, Geschwindigkeit und Nachhaltigkeit eines Transformationsprozesses, und die Klarheit darüber bleibt zunächst Aufgabe der Führung. Fehlende Klarheit zu den Stellhebeln des Erfolgs führt nach unserer Erfahrung zu Aktionismus und, nach anfänglicher Begeisterung der Beteiligten, zu Frustrationen und Enttäuschungen. 
2. Ambition: "Management by Ambition« (MbA) bedeutet, dass jede und jeder im Ergebnis mehr zum Unternehmenswert beiträgt als bisher, also mehr Impact hat. In der Ambitionsphase wird erarbeitet, was erreicht werden könnte, wenn jede und jeder ihr oder sein Bestes gibt. Dazu werden die subjektiven Wahrnehmungen aus den Dialogen der Reflexionsphase allen Beteiligten in einem gemeinsamen Workshop zur Verfügung gestellt und diskutiert. Durch die Diskussion der individuellen, oft voneinander abweichenden Einschätzungen erweitert sich der Verständnishorizont jedes Einzelnen, und neue Lösungsräume tun sich auf. Prädikative und präventive Handlungsoptionen fließen ein; neue Tools, die vorher abgelehnt wurden, finden plötzlich Beachtung. Im Laufe der Diskussionen entsteht ein Konsens über Hürden und Möglichkeiten des zukünftigen Erfolgs. So geeint, formuliert das Team nun eine Ambition - ein SMART-formuliertes Ziel, das alle erreichen wollen und das qualitativ sowie quantitativ messbar ist.

3. Volition: Viele Veränderungen scheitern nicht an einer mangelnden Anfangsmotivation, sondern im Laufe der Umsetzung. Der Umsetzungswille - die Volition - ist nicht stark genug. Volition zu stärken, ist jetzt die Aufgabe von Coach und Führungskraft. In unserem Vorgehen detailliert der Coach jeden Schritt, der notwendig ist, um vom derzeitigen Zustand zur Ambition zu gelangen. Dies erfolgt zunächst mit dem gesamten Team und immer handlungsorientiert - wer muss wann was machen? Wir nennen das »Erfolgstreppe«. Sie erhöht die Umsetzungsverbindlichkeit der Teilnehmenden. Danach erfragt der Coach jedes Individuum, was er oder sie bereit ist, für die Erreichung des Ziels zu geben, und bittet jede und jeden, eine eigene Erfolgstreppe zu bauen. Diese individuelle Erfolgstreppe ist Basis des nachfolgenden Coachings, das individuell Ressourcen stärkt, Haltungen ändert, Kompetenzen aufbaut - je nachdem, was der oder die Einzelne benötigt, um die eigene Ambition als Teil der Teamambition zu erreichen.

\section{Messbarkeit}

Das Beratungsunternehmen zeb führt seit 2011 Veränderungsprogramme bei Finanz- und Gesundheitsdienstleistern mit dem Dreiklang »Reflexion - Ambition - Volition « durch. Alle Programme wurden nach folgenden Kriterien evaluiert: 1. Akzeptanz, 2. Weiterempfehlung (NPS ${ }^{1}$ ), 3. Kompetenzzuwachs, 4. Aktivitätenkennziffern (z. B. Anzahl Termine, Abschlüsse, Einsatz von Tools,

1 Net Promoter Score (NPS) = Quote der aktiven Weiterempfehlung. 
Nutzung von Vertriebshinweisen) und 5. Ergebniskennziffern, darunter Umsatzwachstum und Rentabilität insgesamt und pro Kunde.

Für Regionalbanken in der Schweiz wurde das Konzept, das auf den Vierklang »Reflexion - Ambition - Volition - Nachhaltigkeit« baut, eingesetzt, um die Banken proaktiver zu machen und fähiger, ganzheitlicher auf Kundinnen einzugehen. Für den Verband von unabhängigen und selbstbestimmten Banken war der Nachweis des Erfolgs ein wesentlicher Faktor für einen breiten Rollout. Die Banken haben sich daher zu einer sehr gründlichen und umfassenden Evaluation entschlossen und mehr als 20000 Kund $^{*}$ innen definiert, zu denen eine Kontrollgruppe gebildet wurde. Jeder Kundin einer am Programm teilnehmenden Bank wurde ein in der Kundensegmentierung (z. B. Alter, Einkommen, Produktnutzungsquote) sehr ähnlicher Kunden zugeordnet. Seit drei Jahren wird die Entwicklung der Kund ${ }^{*}$ innen von teilnehmenden und nicht teilnehmenden Banken beobachtet. Der Erfolg hat selbst die Optimist ${ }^{\star}$ innen überrascht: Während am Markt generell und bei den nicht teilnehmenden Banken die Erträge pro Kund ${ }^{*}$ in sanken, konnten die teilnehmenden Banken bei ihren Kund ${ }^{*}$ innen eine deutlich positive Entwicklung verbuchen. Die Ergebnisse sind über die Jahre und in deutsch-, französisch- und italienischsprachigen Regionen vergleichbar - trotz großen regionalen und kulturellen Unterschieden. Das Programm wird bei vielen Banken gleichzeitig im vierten Jahr durchgeführt. Zudem hat die Bankengruppe einen Nachhaltigkeitsprozess aufgesetzt, der Führungskräften aus Banken, die bereits teilgenommen haben, Unterstützungsimpulse in der Weiterführung der Methodik gibt.

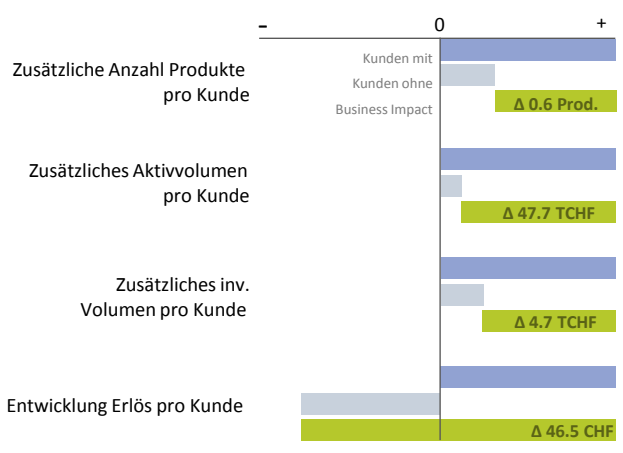

Kunden mit Vertriebsexzellenz

(Experimentalgruppe)

Kunden ohne Vertriebsexzellenz

(Kontrollgruppe)

Business Impact

Quelle Raiffeisen Schweiz

Abbildung 3: Veränderung kundenbezogener Werte mit und ohne Programm innerhalb eines Jahres (Hinweis: die Werte geben absolute Veränderungen innerhalb eines Jahres an) 


\section{Managementagenda}

Zusammenfassend empfehlen wir, auf das Verfehlen von Unternehmenszielen nicht vornehmlich dadurch zu reagieren, dass »die Zügel angezogen« werden, also die Organisation umstrukturiert wird, mehr Vorgaben gemacht und mehr kontrolliert wird. Vielmehr appellieren wir dafür, einen Prozess zu definieren, der Mitarbeitende aktiviert, ihr Bestes für das Unternehmen zu geben. Dies gilt vor allem auch in Zeiten, in denen Buzzwords wie Agilität und Digitalisierung die Kommunikation bestimmen und Veränderungen zum Selbstzweck zu werden drohen, um bloß den Zug in die Modernität nicht zu verpassen. Wir plädieren für den Wandel, Unternehmen agiler auszurichten und die Möglichkeiten der Digitalisierung in der Breite zu nutzen. Dazu gilt es, in den von der Veränderung betroffenen Bereichen einen Prozess aufzusetzen, der orchestriert, wie Mitarbeitende ihre Ambition zur Unternehmenszielerreichung einbringen können. Wenn es, wie hier dargestellt, gelingt, viele Mitarbeitende und Führungskräfte im Sinne der Unternehmensziele beziehungsweise der neuen Anforderungen zu motivieren, dass sie ihr Bestes geben wollen, findet der Wandel quasi automatisch statt. Dazu bedarf es eines transparenten Vorgehens und einer anfänglichen Unterstützung durch einen ausgebildeten Coach. Der sichert den erlebten Erfolg und den Methodentransfer auf die Führungskraft. Wir nennen diesen Prozess »Freedom within Frames«. Freedom im Definieren des Weges, Frames, die die Richtung vorgeben und im Idealfall wesentliche Stellhebel der Veränderung benennen. Kleinteilige und vielfach unverbundene Führungs-, Vertriebs- und Teamentwicklungsprogramme sollten einfach aufgegeben werden: Sie strapazieren nur Zeit- und Finanzbudgets und die Nerven der Mitarbeitenden und Führungskräfte ohnehin. Die Umsetzungslücken zwischen strategischer Ausrichtung und praktischer Umsetzung werden nur Unternehmen schließen, die für Führungskräfte und Mitarbeitende einen gemeinsamen Erfolgsrahmen schaffen, der auf Reflexion (Warum wollen wir uns verändern?), Ambition (Was wollen wir erreichen?), Volition (Welcher Verhaltensänderung bedarf das meinerseits?) beruht.

Schließlich sollte der Erfolg von Veränderungsprozessen immer transparent messbar sein. Darüber geben die Akzeptanz der Mitarbeitenden und Führungskräfte, der wahrgenommene Kompetenzgewinn sowie Kennziffern, bezogen auf Aktivitäten und Ergebnisse, Auskunft - vor allem jedoch sind es die in diesem Programm ebenfalls messbaren und nachhaltigen Verhaltensveränderungen von vielen. Sie formen die neue agilere und performantere Unternehmenskultur im digitalen Umfeld. 


\section{Literatur}

Benning-Rohnke, E., Greif, S. (2010). Kundenorientierung - Warum sie oft scheitert und wie sie besser machbar ist. In G. Greve, E. Benning-Rohnke (Hrsg.), Kundenorientierte Unternehmensführung. Konzept und Anwendung des Net Promoter Score in der Praxis (S. 117-156). Wiesbaden: Gabler.

Benning-Rohnke, E., Hasebrook, J. (2018). Das Knowing-Doing-Gap schließen: Wie Mitarbeiter aus eigenem Antrieb Unternehmensziele engagiert umsetzen. Personalführung, (11), 19-24.

etventure/GfK (2018). Studie Digitale Transformation 2018: Hemmnisse, Fortschritte, Perspektiven. Trendreport, Berlin. https://sdv-dialogmarketing.ch/wp/wp-content/uploads/2018/10/etventure_Studie_2018-Trendreport-Digitale-Transformation-2018.pdf [6.3.2020].

Fiorina, C. (2000). The Transformation Accelerates. Speech (october 17). CTEA Conference. Detroit, Michigan. www.hp.com/hpinfo/execteam/speeches/fiorina/ceo_ctea_00.html [1.5.2020].

Geißler, H. (2011): Coaching meets Training - zur Lösung des Transferproblems durch "virtuelles Transfercoaching (VTC)«. In R. Wegener, A. Fritze, M. Loebbert (Hrsg.), Coaching entwickeln. Forschung und Praxis im Dialog (S. 123-134). Wiesbaden: Springer VS.

Gollwitzer, P. M., Kuhl, J., Heckhausen, H. (1996). Das Rubikonmodell der Handlungsphasen. In J. Kuhl, H. Heckhausen (Hrsg.), Enzyklopädie der Psychologie. Band 4: Motivation, Volition und Handlung (S. 531-582). Göttingen: Hogrefe.

Gollwitzer, P. M., Sheeran, P. (2006). Implementation intentions and goal achievement: A meta-analysis of effects and processes. Advances in Experimental Social Psychology, 38, 69-120.

Greif, S. (2008). Coaching und ergebnisorientierte Selbstreflexion. Göttingen: Hogrefe.

Greif, S. (2013). Putting goals to work in coaching: The complexities of implementation. In S. David, D. Clutterbuck, D. Megginson (Eds.), Beyond goals: Effective Strategies for Coaching and Mentoring (pp. 125-149). Farnham, Surrey: Gower.

Greif, S., Schmidt, F., Thamm, A. (2012). Warum und wodurch Coaching wirkt - Ein Überblick zum Stand der Theorieentwicklung und Forschung über Wirkfaktoren. Organisationsberatung, Supervision, Coaching (OSC), 19 (4), 375-390. DOI: 10.1007/s11613-012-0299-4

ITU-T Focus Group (2016). Digital Financial Services. Ecosystem. Technical Paper. Genf: International Telecommunication Union. https:/www.itu.int/en/ITU-T/focusgroups/dfs/Documents/09_2016/FINAL\%20ENDORSED\%20ITU\%20DFS\%20Introduction\%20Ecosystem\%20 28\%20April\%202016_formatted\%20AM.pdf [6.3.2020].

Katayama, H., Bennett, D. (1999). Agility, adaptability and leanness: A comparison of concepts and a study of practice. International Journal of Production Economics, 60-61, 43-51.

Kreggenfeld, U., Reckert, H.-W. (2008). Virtuelles Transfercoaching: Die Transferquote verdreifachen. In H. Geißler (Hrsg.), E-Coaching (S. 217-224). Baltmannsweiler: Schneider-Verlag Hohengehren.

Linder, J. C., Cantrell, S. (2000). Changing Business Models: Surveying the landscape. Cambridge, MA: Working Paper Institute for Strategic Change.

Schaap, P. (2014). New Business Models with an Operational Hybrid Currency System: A Practical Application of Value Creation. Working Paper. Nijmegen: Radboud University Nijmegen.

Soulami, S. (2014). Project Hybride Bankieren: Legal Context. Unpublished Research. Nijmegen: Radboud University Nijmegen.

Volkens, B., Anderson, K. (2018). Digital Human. Frankfurt a. M.: Campus.

Webers, T. (2015). Systemisches Coaching. Psychologische Grundlagen. Heidelberg: Springer. 


\section{Die Autor`innen und Herausgeber*innen}

Silvano Ackermann, M. A. Sozialwissenschaften, ist Soziologe und Coach und arbeitet als wissenschaftlicher Assistent im Rahmen der Coaching Studies FHNW. Sein Forschungsschwerpunkt ist Coaching in der beruflichen Integration. Weitere aktuelle Forschungsprojekte und Publikationen beziehen sich auf die Zukunft des Coachings, Coaching-Prozessforschung und Chatcoaching. E-Mail: silvano.ackermann@fhnw.ch

Jeremias Amstutz, M. A. in Sozialer Arbeit, ist wissenschaftlicher Mitarbeiter (Senior) und Doktorand am Institut Beratung, Coaching und Sozialmanagement an der Hochschule für Soziale Arbeit, Fachhochschule Nordwestschweiz. Arbeitsund Forschungsschwerpunkte: Sozialmanagement, Social-Impact-Modell, Case Management, Design Thinking und branchen- und sektorenübergreifende Kooperationen. Co-Präsident des Vereins sozialinfo.ch.

Publikationen und Projekte: https://www.fhnw.ch/de/personen/jeremias-amstutz. E-Mail: jeremias.amstutz@fhnw.ch

Elke Benning-Rohnke studierte Psychologie und BWL an den Universitäten Mannheim und Kiel. Ihre berufliche Laufbahn begann sie 1984 bei Procter \& Gamble. 1996 wurde sie in den Vorstand der Wella AG, Darmstadt, berufen und verantwortete das weltweite Friseurgeschäft. Seit dem Jahr 2000 berät sie mit eigenen Gesellschaften und in Kooperation mit international aufgestellten Beratungshäusern Großunternehmen zu profitablem organischem Wachstum an den Stellhebeln Markt, Kunde und Organisation. Sie hält zudem verschiedene Aufsichtsrats- und Beiratsmandate.

E-Mail: ebr@benningcompany.com

David Clutterbuck is one of the earliest pioneers of coaching. Visiting professor at four universities, he is co-founder of the EMCC, for which he is now special ambassador, tasked with spreading good practice globally. David's current 
research includes coaching teams of teams, coach-AI partnerships and coaching in politicised environments. He has the ambition to create 5 million schoolage coaches and mentors.

His website is www.coachingandmentoringinternational.org Email: david@davidclutterbuckpartnership.com

Claudia Deniers holds a PhD in English Language and Literature and an MSc in Career Management and Coaching. She works as a Senior Leadership Development Manager and Executive Coach designing and delivering leadership development programmes for senior leaders. She also offers pro-bono career and business coaching for Grow2Glow, a coaching initiative for women at Siemens. Dr Claudia Deniers, Gistlstraße 103a, 82049 Pullach, Germany.

Email: claudia.deniers@gmail.com,www.linkedin.com/in/claudiadeniers

Dr. Silvia Deplazes, MBA, ist Mitglied der Hochschulleitung und Leiterin der Abteilung Weiterbildung an der Pädagogischen Hochschule Graubünden. Sie ist Coach und forscht und lehrt im Gebiet der professionellen Gesprächsführung und Beratung, insbesondere zu Coaching.

E-Mail: silvia.deplazes@phgr.ch

Dr. Thomas H. Dyllick, ist Coach und selbstständiger Trainer am Institut für Selbstmanagement und Motivation Zürich (ISMZ), Spin-off der Universität Zürich, und wissenschaftlicher Mitarbeiter am Lehrstuhl für Sozialpsychologie an der Universität Mannheim.

E-Mail: thomas.dyllick@uni-mannheim.de

Dr. Harry Enke ist Physiker und Leiter der Abteilung Supercomputing und E-Science am Leibniz-Institut für Astrophysik Potsdam. Er hat an zahlreichen Projekten und Studien im Bereich digitaler wissenschaftlicher Infrastrukturen teilgenommen und ist langjähriger Sprecher des AK Forschungsdaten der Leibniz-Gemeinschaft.

E-Mail: henke@aip.de, Internet: www.aip.de

Dr. Neela Enke (Biologin, Coach, Mediatorin, Trainerin) hat als Postdoc Studien zum Digital Datasharing in der Biodiversitätsforschung durchgeführt. Als zertifizierte Coachin und ausgebildete Mediatorin unterstützt sie Postdocs, Hochschulangestellte sowie Führungskräfte und begleitet Menschen, Teams und Organisationen bei der konstruktiven Lösung von Konflikten.

E-Mail: nenke@scienza-berlin.de, Internet: www.scienza-berlin.de 
Dr. Harald Geißler war bis zu seiner Emeritierung 2015 Universitätsprofessor für Berufs- und Betriebspädagogik. 2016 gegründete er das Weiterbildungsinstitut »Online-Coaching-Lernen" (www.online-coaching-lernen.de). Seit 2020 leitet er das Institut für Online-Coaching an der Hamburger Fern-Hochschule (HFH). Wichtigste Publikationen: »Grundlagen des Organisationslernens« (1994), »Organisationspädagogik « (2000), »E-Coaching « (2008), »E-Coaching und Online-Beratung « (2012), »Bewertung von Coachingprozessen « (2015) und »Die Grammatik des Coachens« (2017).

E-Mail: Dr.H.Geissler@t-online.de

Joachim Hasebrook studierte Psychologie und Informatik und promovierte zum Thema »Lernhilfen in multimedialen Lernsystemen«. Er habilitierte mit der Arbeit »Learning Support Systems for Organizational Learning «. Nach der Habilitation wurde er als Professor für »E-Learning and Work Design« an der Universität zu Lübeck berufen und übernahm die akademische Leitung der International School of New Media. Heute hat er den Lehrstuhl für Human Capital Management an der Steinbeis-Hochschule Berlin inne und ist akademischer Leiter der zeb.business.school Steinbeis-Hochschule Berlin.

E-Mail: jhasebrook@zeb.de

Mathias Hofmann, Dipl.-Pädagoge und Master Business Consulting, ist Coach (EASC) und Gestaltberater (FPI) sowie seit 2002 geschäftsführender Gesellschafter SHS CONSULT GmbH Bielefeld, Mitglied im Vorstand der EASC e. V. Schwerpunkte: Change Management, Führungskräftentwicklungprogramme und Executive Coaching.

Information und Veröffentlichungen siehe www.shs-consult.de.

E-Mail: mh@shs-consult.de

Dr Stella Kanatouri works as a research consultant at Harris Interactive AG. Stella's academic research work published under the title »The Digital Coach« (2020), focuses on the use of new media in coaching. Publications include, amongst others: »Adapting to working with new technologies« (Book: »The Sage Handbook of Coaching «, 2016) and »The role of online coaching tools in the coaching process (Journal: »Wirtschaftspsychologie aktuell«, 2017).

Email: stella.kanatouri@hotmail.de

Axel Klimek ist Geschäftsführer des Center for Sustainability Transformation, $\mathrm{GmbH}$, Mitgründer von Make Change Work und Lehrbeauftragter der Hochschule Darmstadt (h_da). Er ist seit über dreißig Jahren als Coach und seit zwan- 
zig Jahren als Organisationsentwickler tätig. Axel Klimek hat in über dreißig Ländern Organisationen darin unterstützt, komplexe Change-Prozesse zu steuern und die Zusammenarbeit und die Performance von Teams und Führungskräften zu verbessern; zu seinen Kunden gehören unter anderem Allianz, EY, Fresenius, GIZ, Lufthansa, T-Systems und Unilever.

E-Mail: a.klimek@make-change-work.com

Dr. Monika Klinkhammer ist Sozial- und Erziehungswissenschaftlerin, Supervisorin/Coach (DGSv, DVG, ECP), Gestalttherapeutin und Lehrcoach. Sie hat zum Thema "Supervision und Coaching für Wissenschaftler*innen" promoviert und berät seit über 22 Jahren mit über 600 Beratungsprozessen Wissenschaftler*innen zu Fach-, Karriere- und Führungsthemen. Sie leitet eine Supervisions- und Coachingweiterbildung an der ASH Berlin und ist Gründungsmitglied des Coachingnetzes Wissenschaft e. V. sowie Gutachterin DGSv.

E-Mail: Monika.Klinkhammer@t-online.de,

Internet: www.MonikaKlinkhammer.de

Prof. Hansjörg Künzli leitet die Fachgruppe Diagnostik und Beratung des Psychologischen Instituts der Zürcher Hochschule für Angewandte Wissenschaften ZHAW. Er ist Coach und forscht und lehrt in den Gebieten Coaching und Methodenlehre. E-Mail: kasg@zhaw.ch

Astrid Laudage, Betriebswirtin, zusätzlich Masterstudium im Studiengang Business-Coaching und Change-Management, Euro FH-Hamburg, hat Fach- und Führungserfahrung in Wirtschaftsunternehmen und Verwaltung sowie als Prozessbegleiterin im INQA-Audit »Zukunftsfähige Unternehmenskultur«. Seit 2010 ist sie geschäftsführende Gesellschafterin Laudage Konzept GmbH, Telgte. Internet: www.laudage-konzept.de

Prof. Dr. Annamarie Ryter ist Dozentin an der Pädagogischen Hochschule der FHNW. Sie unterrichtet unter anderem spezifische Module in diversen Coachingausbildungen und ist Senior Mentor Coach bei Trigon. Ihre Schwerpunkte sind systemisch-lösungsorientiertes Coaching und Empathisches Coaching (metapuls), ihre Leidenschaft ist allerdings Methodenvielfalt im Coaching - analog und digital. Sie ist seit 2016 Mitherausgeberin der Tagungsbände »Coaching meets Research«. Ihre breite Publikationsliste umfasst auch diverse Artikel zu Coaching. Seit 2005 arbeitet sie als Business Coach in eigener Firma (Einzel- und Teamcoachings). Mehr dazu unter www.bildbar.ch.

E-Mail: annamarie.ryter@fhnw.ch 
Marco Schärer studierte BWL mit Vertiefung Marketing und bildete sich an der Universität St. Gallen (HSG) zum Sales Executive/Dipl.-Vertriebsleiter weiter. Seine Laufbahn begann 2003 bei der St. Galler Kantonalbank in der Privatkundenberatung. Danach war er für den Vertrieb von Investmentprodukten bei Credit Suisse verantwortlich. Heute leitet er das Vertriebsmanagement und Enabling bei Raiffeisen Schweiz und begleitet in seiner Rolle die Raiffeisenbanken in der Erhöhung der Vertriebsleistung.

E-Mail: marco.schaerer@raiffeisen.ch

Prof. Dr. Werner Stork hat Volkswirtschaftslehre und Betriebswirtschaftslehre in Münster und in Valdivia (Chile) studiert und am Institut für Genossenschaftswesen der WWU in Münster zur Organisation betrieblicher Lern- und Innovationsprozesse promoviert. Nach vierzehn Jahren leitender Tätigkeit in den Bereichen HRM und Marketing \& Vertrieb übernahm er 2013 eine Professur für Organisation und Management an der Hochschule Darmstadt (h_da). Seine Arbeitsschwerpunkte sind: nachhaltige Unternehmensführung, insbesondere Corporate Learning, Corporate Health sowie Innovations-, Change und Transformation Management. Werner Stork ist Direktor am Zentrum für nachhaltige Wirtschafts- und Unternehmenspolitik (www.znwu.de) und Mitglied in den Forschungs- und Promotionszentren F:NE (Nachhaltige Prozesse und Verfahren) und DKMI (Digitale Kommunikations- und Medien-Innovationen) der h_da.

E-Mail: werner.stork@h-da.de

Nicola Strong, BSc (Hons), MSc, MBCS, MABP, IFIP 9.5, is the Director of Strong Enterprises focusing on exploring authentic communication through digital change. Nicola's project work includes research into ethical artificial intelligence, designing chatbots for coaching and mentoring, developing leadership using gamification and collective intelligence through social media.

Email: nicola@strong-enterprises.com

Dr Nicky Terblanche (MScEng, MPhil, $\mathrm{PhD}$ ) is a senior lecturer and researcher at the University of Stellenbosch Business School (USB), South Africa. He researches transition coaching, transformative learning, Social Network Analysis, complexity theory and using artificial intelligence in coaching.

Email: nicktyt@usb.ac.za

LinkedIn: https://za.linkedin.com/in/dr-nicky-terblanche-phd-b004177

Research: https://www.researchgate.net/profile/Nicky_Terblanche 
Volker Jörn Walpuski, Religionspädagoge, Diakoniemanager (M. A.), Organisationsberater (M. A.), ist freiberuflicher Supervisor und Coach (DGSv) sowie Mediator (BM). Als wissenschaftlicher Mitarbeiter der Hochschule Hannover forscht und veröffentlicht er zu arbeitsbezogener Beratung zwischen kritischreflexiver Aufklärung und Funktionalisierung.

E-Mail: Volker.Walpuski@hs-hannover.de

Dr. Robert Wegener ist Co-Leiter der Coaching Studies FHNW, Dozent für Coaching im MAS Coaching und Leiter verschiedener CAS-Kurse. Seit 2010 leitet er den Internationalen Coachingkongress »Coaching meets Research «. Zu seinen zentralen Themen gehört die Analyse und Steuerung bedeutsamer Momente im Coaching. Seit 2020 ist Robert Wegener Mitherausgeber der Zeitschrift "Coaching Theorie und Praxis«. Als Initiator und Mitherausgeber verantwortete er verschiedene Publikationen, z. B. »Coaching-Praxisfelder « und »Coaching und Gesellschaft«. Aktuell forscht er mit seinem Team zu künftigen Szenarien im Coaching (mit Prof. Dr. Carsten Schermuly) und zum Einsatz psychologischer Tests im Coaching. Seit 2010 ist er Business Coach in eigener Praxis mit Fokus auf Einzel-, Teamcoachings und Coaching-Supervision.

E-Mail: robert.wegener@fhnw.ch 